\title{
A Conceptual Simulation Model for Release Scenario Analysis of a Hypothetical Site in Columbia Plateau Basalts
}

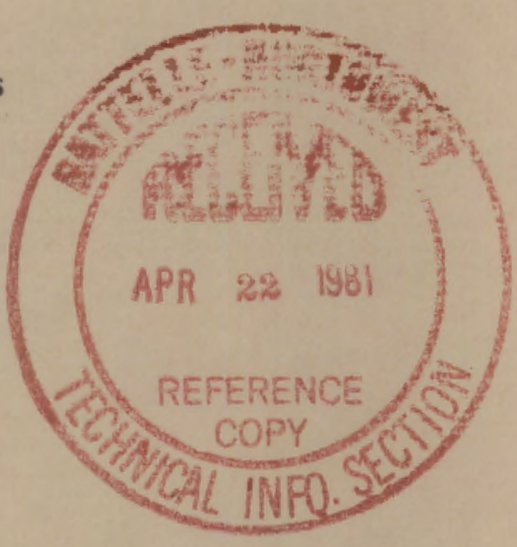

January 1981

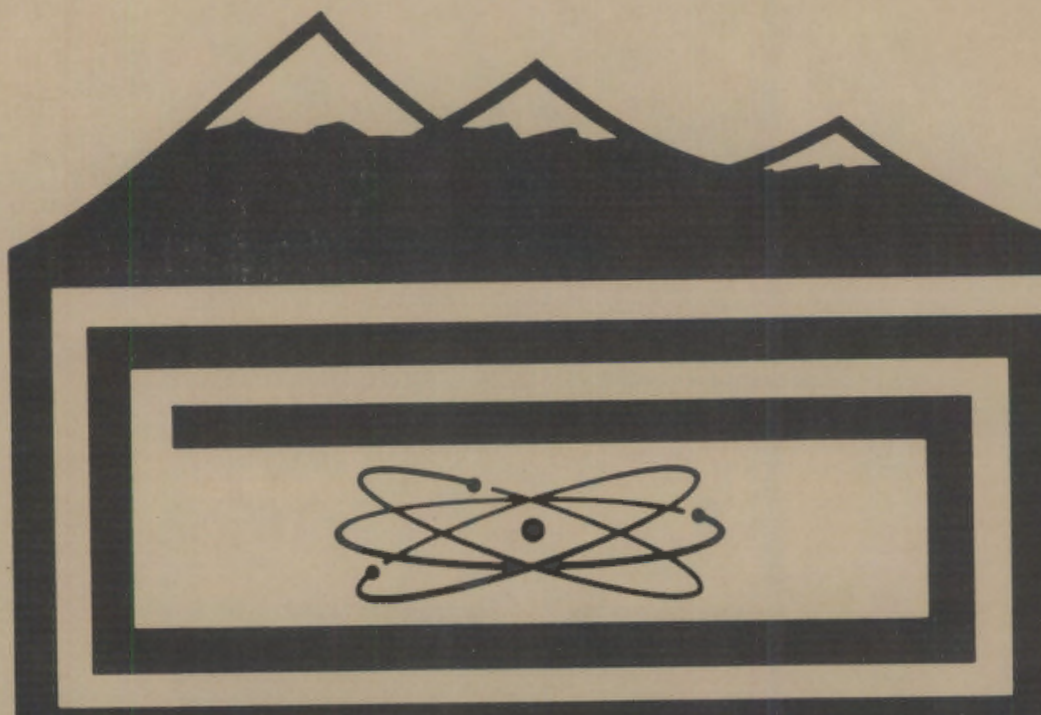

Prepared for the Office of Nuclear Waste Isolation under its contract with the U.S. Department of Energy

Pacific Northwest Laboratory

Operated for the U.S. Department of Energy

by Battelle Memorial Institute 
NOTICE

This report was prepared as an account of work sponsored by the United States Government. Neither the United States nor the Department of Energy, nor any of their employees, nor any of their contractors, subcontractors, or their employees, makes any warranty, express or implied, or assumes any legal liability or responsibility for the accuracy, completeness or usefulness of any information, apparatus, product or process disclosed, or represents that its use would not infringe privately owned rights.

The views, opinions and conclusions contained in this report are those of the contractor and do not necessarily if esent those of the United States Government or the United States Department of Energy.

\author{
PACIFIC NORTHWEST LABORATORY \\ operated by \\ BATTELLE \\ for the \\ UNITED STATES DEPARTMENT OF ENERGY \\ Under Contract DE-AC06-76RLO 1830
}

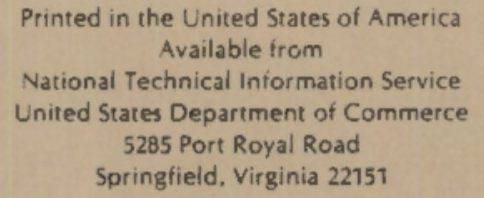

Price: Printed Copy $\$$ _: Microfiche $\$ 3.00$

- Pages Selling Price

$\begin{array}{lr}001-025 & \$ 4.00 \\ 026-050 & \$ 4.50 \\ 051-075 & \$ 5.25 \\ 076-100 & \$ 6.00 \\ 101-125 & \$ 6.50 \\ 126-150 & \$ 7.25 \\ 151-175 & \$ 8.00 \\ 176-200 & \$ 9.00 \\ 201-225 & \$ 9.25 \\ 226-250 & \$ 9.50 \\ 251-275 & \$ 10.75 \\ 276-300 & \$ 11.00\end{array}$


Assessment of Effectiveness of Geologic Isolation Systems

A CONCEPTUAL SIMULATION MODEL FOR RELEASE SCENARIO ANALYSIS OF A HYPOTHETICAL SITE IN COLUMBIA PLATEAU BASALTS

J. A. Stottlemyre

G. M. Petrie

G. L. Benson

J. T. Zellmer

January 1981

Prepared for the

Office of Nuclear Waste Isolation Under its Contract with the U.S. Department of Energy

Pacific Northwest Laboratory

Richland, Washington 99352 



\section{PREFACE}

This report is a status report for an evolving methodology for release scenario development for underground nuclear waste repositories. As such, it is intended for use as a reference point and a preliminary description of an evolving geoscience methodology. When completed this methodology will be used as a tool in developing disruptive release scenarios for analyzing the longterm safety of geological nuclear waste repositories.

As a draft, this report was used as a focal point for discussion at a Release Scenario Analysis Workshop held in August, 1979, by the Waste Isolation Safety Assessment Program (WISAP) in Seattle, Washington. With the exception of numerous editing and typographical corrections, this report contains the same information as the earlier circulated draft and serves to document the state of the methodology at that time (August 1979). A new status report on the Release Scenario methodology is currently scheduled for release the end of 1980. This next version will contain a new, updated version of the release scenario methodology and describes the many changes implemented as a result of comments by the participants of the FY-1979 workshop following discussions of this report.

While a basalt environment is used as an example, this report is not intended to reflect an actual site safety assessment for a repository in a media. It is rather intended to present a methodology system framework and to provide discussions of the geological phenomena and parameters that must be addressed in order to develop a methodology for potential release scenarios. It is also important to note that the phenomena, their interrelationships, and their relative importance along with the overall currrent structure of the mode 1 will change as new geological information is gathered through additional peer review, geotechnical input, site specific field work, and related research efforts. 


\section{ACKNOWLEDGMENT}

This research was supported by the Waste Isolation Safety Assessment Program being conducted by Pacific Northwest Laboratory. This program was sponsored by the Office of Nuclear Waste Isolation, which is managed by Battelle Memorial Institute under contract EY-76-C-06-1830 with the Department of Energy. On October 1, 1979, WISAP became the Assessment of Geologic Effectiveness of Geologic Isolation Systems (AEGIS) Program and the Waste/Rock Interactions Technology (WRIT) Program. This report was issued by AEGIS.

The contents of this report represent the efforts of a relatively large group of individuals. In the body of the report, reference is made to: 1) the WISAP Task 1 Research Team, and 2) the Consulting Team. Individual members of these groups are listed below. To keep the document a manageable size, many of the details associated with the topics presented herein are deferred to a set of topical reports contained in the reference list. Most of the discussions in this report are based on the inputs of the consulting team. 
WISAP Task 1 Participants

\begin{tabular}{|c|c|c|c|c|}
\hline \multicolumn{2}{|c|}{ Research Team } & \multicolumn{3}{|c|}{ Consulting Team } \\
\hline Name & Location & Name & Location & Study Area \\
\hline G. L. Benson & PNL & C. Bull & Ohio State Univ. & Glaciology \\
\hline T. N. Bishop & PNL & H. Coombs & Univ. of Washington & Struc. Geo. \\
\hline R. A. Craig & PNL & B. Crowe & Los Alamos Sci.Labs & Volcanology \\
\hline H. P. Foote & PNL & S. Davis & Univ. of Arizona & Hydrology \\
\hline 0. D. Hostetler & PNL & R. Gastil & Freedom House & Man-Caused Events \\
\hline J. J. Jacobson & PNL & W. Hartman & Univ. of Arizona & Meteorites \\
\hline G. B. Lane & PNL & J. Hills & Univ. of Texas & Struc. Geo. (salt) \\
\hline G. M. Petrie & PNL & R. Kehle & Turk, Kekle and Assoc. & Struc. Geo. (salt) \\
\hline W. M. Phillips & PNL & G. Kukla & Lamont Doherty Observ. & Climatology \\
\hline J. A. Stott lemyre & PNL & E. Lovejoy & Univ. of Texas & Struc. Geo. (basin \\
\hline R. W. Wallace & PNL & & & and range) \\
\hline W. H. Walters & PNL & S. Mara & Stanford Research Inst. & Geomorphology \\
\hline J. T. Zellmer & PNL & M. Schwartz & Western Wash. Univ. & Sea Level Fluc. \\
\hline & & 'B. Smernoff & Hudson Institute & Man-Caused Events \\
\hline & & D. Tubbs & Rodger Lowe \& Assoc. & Geomorphology \\
\hline & & M. Veatch & Shannon and Wilson & Hydrology \\
\hline & & L. Wight & Teknekron, Inc. & Seismology \\
\hline
\end{tabular}





\section{CONTENTS}

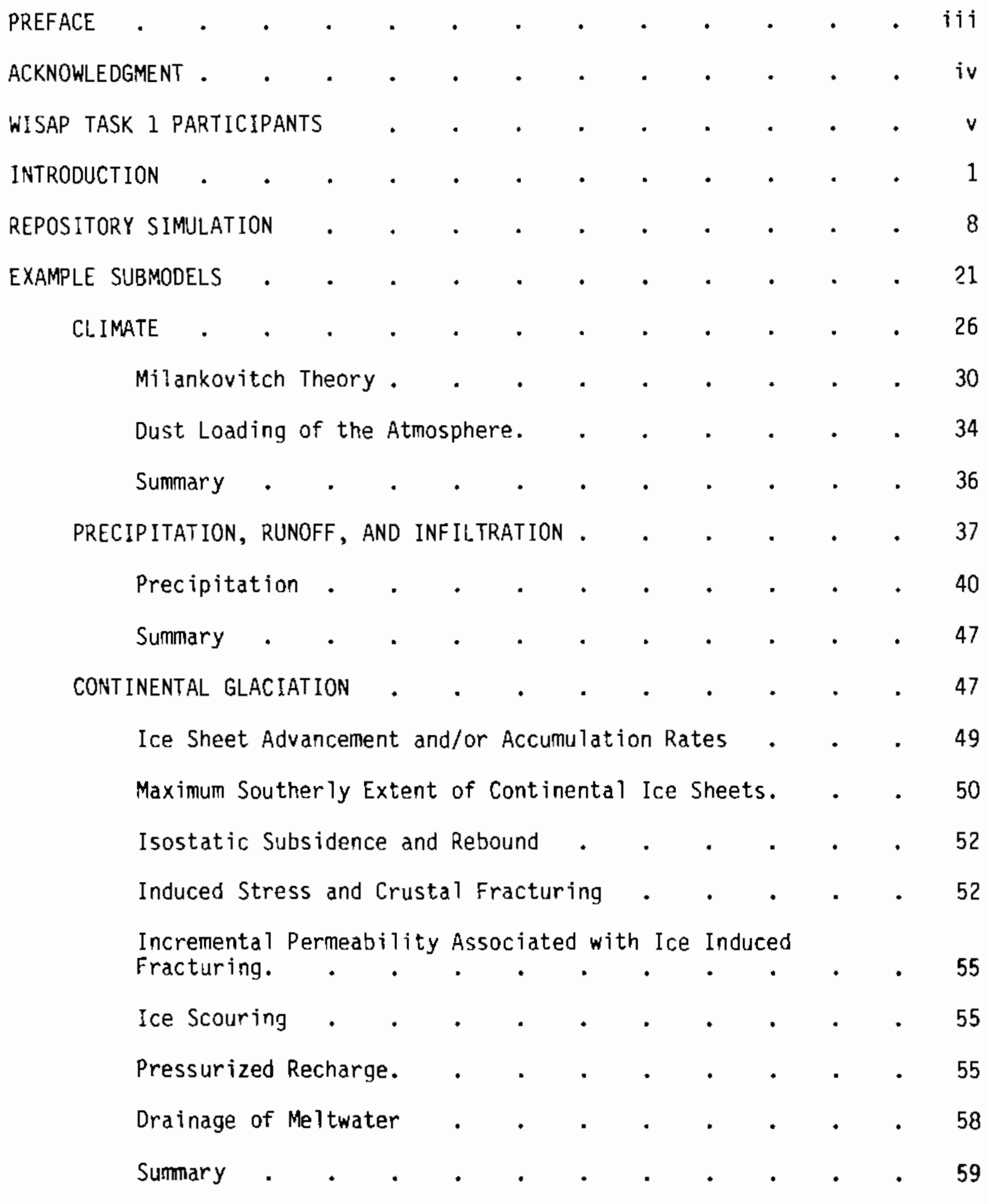


ALPINE GLACIATION.$\quad$. . . . . . . . . . 60

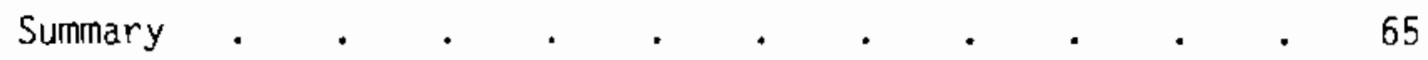

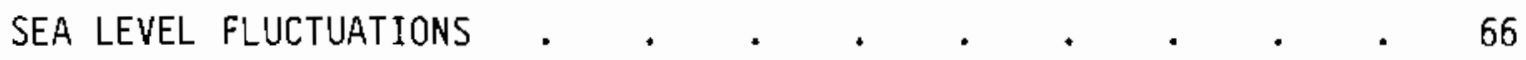

GEOMORPHIC EVENTS . . . . . . . . . . . . 71

River Flows . . . . . . . . . . . . 73

Inundation of the Basin . . . . . . . . 77

Recharge . $\quad . \quad$. . . . . . . . . . . . 79

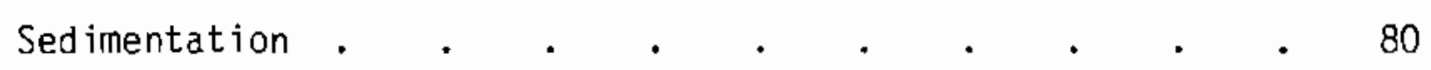

River Course Alteration . . . . . . . . . . . 80

General Denudation . . . . . . . . . . 82

Stream Erosion . $\quad . \quad$. $\quad$. . . . . . . 82

Flood Erosion . $\quad . \quad$. $\quad . \quad$. . . . . 86

Wind Erosion . . . . . . . . . . . . . 86

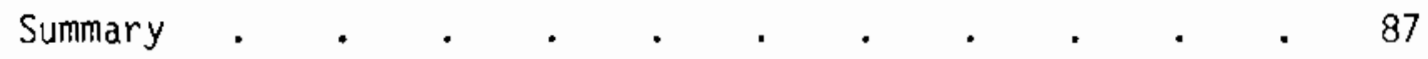

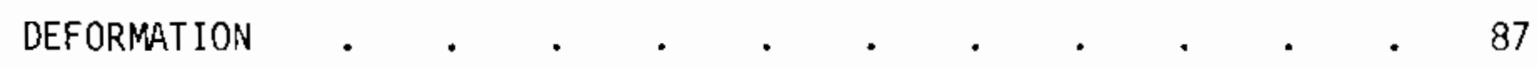

Undetected and/or Accelerated Deformation of the Basalts . 91

Probability of an Undetected Anticline . . . . . . 94

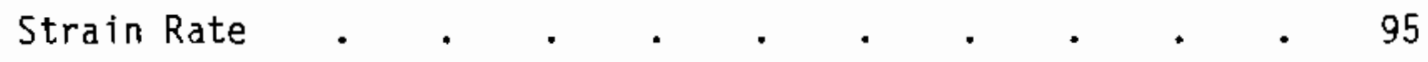

Probability of a Fault Associated with the Folding. . . 96

Probability of Shear Displacement on Pre-Existing Joints 96

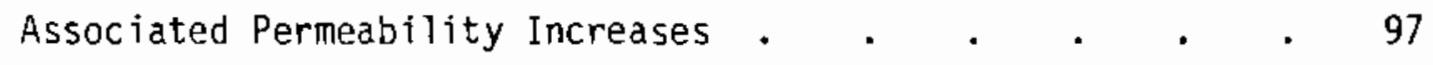

Faulting in the Sub-basalt Basement. . . . . . . 101

Vibratory Excitation and Backfill Material Response . . 102

Impact Fracturing . $\quad . \quad$. $\quad . \quad$. $\quad . \quad$. 104

Hydraulic Fracturing. . . . . . . . . 105 
Summary $\quad . \quad$. $\quad . \quad$. . . . . 108

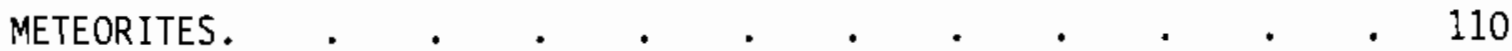

Argument to Eliminate Future Meteorite Analyses. . . 110

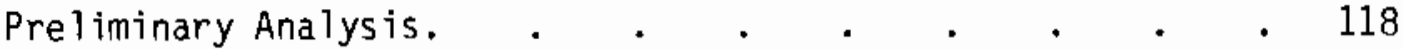

Summary . . . . . . . . . . . . . . 118

MAGMATIC ACTIVITY . . . . . . . . . . . . . . 123

Summary . $\quad . \quad$. $\quad . \quad$. . . . . . . . . 129

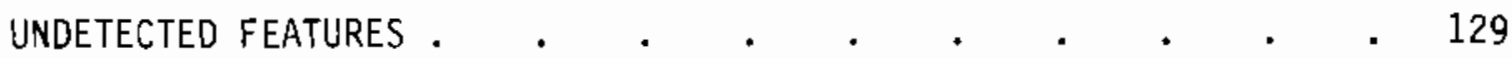

Undetected Boreholes. . . . . . . . 132

Basaltic Ring Structures . . . . . . . 132

Remnant Stream Beds . . . . . . . . . . . . 134

Lava Tubes. $\quad . \quad$. $\quad . \quad$. . . . . . . 137

Summary . . . . . . . . . . . . . . 137

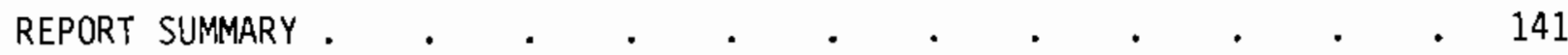

Interface Between Release Scenario and Release Consequence

Site Specific Nature of the Problem. $\quad . \quad$. $\quad$. 142

Columbia Plateau Submodels . . . . . . . . 142

Incorporation of Near Field Results. . . . . . 143

Interactive Utilization of the Tool. . . . . 143

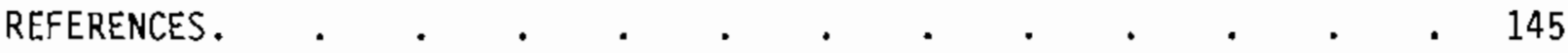

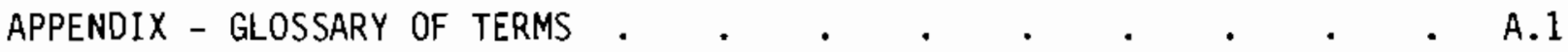




\section{FIGURES}

1 Waste Isolation Safety Assessment Program . . . . . . 3

2 Logic Flow Diagram . . . . . . . . . . . . . . . 9

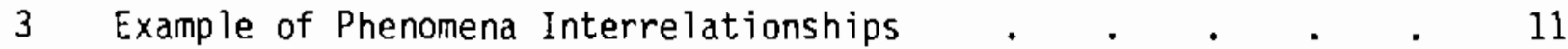

4 Example Layer Earth Model. . . . . . . . . . . 12

5a Initial System State Time $=0$ Years. . . . . . . . . . 15

5b System Perturbation Time $=10^{\mathrm{N}}$ Years $. . . \quad . \quad . \quad . \quad 15$

$5 \mathrm{c} \quad$ Breach (Potential Failure) Time $=10^{\mathrm{N}+\mathrm{M}}$ Years $. \quad . \quad$. $\quad 16$

5d Failure Time $=10^{N+M+L}$ Years $\quad . \quad$. . . . . . . . . . 16

6 Submodel Block Diagrams . . . . . . . . . . . . . . 23

7 The Columbia Prateau (RHO-BWI-78-100) . . . . . . . . 26

8 Major Topographic Features (RHO-BWI-78-100) . . . . . . 27

9 Simplified Cross-Section of Study Area . . . . . . . . . 28

10 Astronomical Climatic Index (ACLIN) as a Function of Time . . 32

11 ACLIN for 122,000 B.P. (Before Present) to 60,000 A.P. (After

Present).

12 Future Natural Climate vs. Time as Predicted From ACLIN Without Ash Load Perturbations . . . . . . . . . . . 35

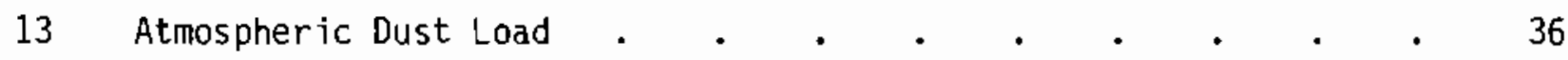

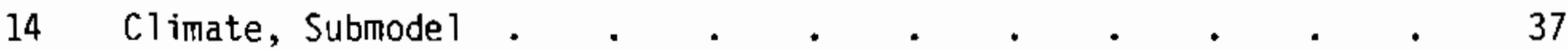

15 Calculation of Difference of Summer Precipitation in $\mathrm{mm}$. Day-1

Between 18,000 Years BP and Present Day, by Members of CLIMAP

16 Test Density Curves Relating Precipitation to the climatic Index

17 Possible Relationships Among Rainfall, Recharge, and Regional Hydraulic Gradients 
18 Glacial Areas of the Conterminous United States . . . . 51

19 Example Stress Conditions Beyond the Edge of an Ice Sheet . . 54

20 Conceptualization of Glacial Recharge of Ground Water . • . 56

21 Estimated Annual Average Columbia River Flows. • . . . 59

22 Continental Glaciation Logic Flow Chart . . . . . 61

23 Areas Affected by Mountain Glaciers in the U.S.A. • . . 64

Probability of Alpine Glaciation in the Great Basin as a
Function of Distance from a Dominant Peak . . . 66

25 Alpine Glaciation Flow Chart . . . . . . . . 67

26 Logic Flow for Sea Level fluctuations . . . . . . 72

27 Assumed Extent of Glacial Advance at 18,000 Years B.P. . . 74

28 Extent of Missoula Flooding . . . . . . . . 76

29 Development of a Hydraulic Constriction at Wallula Gap . . 78

30 Approximate Area of Hanford Reservation Inundated by a Flow of

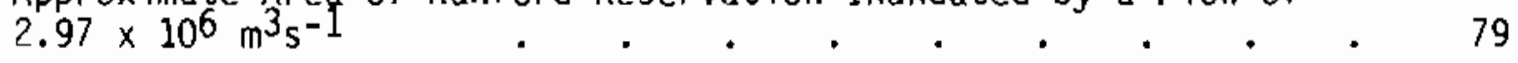

31 Climate and Sediment Yield . . . . . . . . . 81

32 Suspended Solids Denudation Rate as a Function of Elevation . 83

33 Rates of Denudation . . . . . . . . . 85

34 Logic Flow Diagram for Geomorphic Events Submodel . . $\quad 88$

35 Earthquake Epicenters for the West and Eastern Washington Data Files . . . . . . . . . . 93

Stress Orientation, Pacific Northwest, and Basin Range
Provinces . . . . . . . . 95

37 Fault Intersection Probabilities . . . . . . . . 98

38 Parallel Plate Fracture Model c . . . . . . . . 99

39 Conductivity vs. Fracture Width for Various Joint Spacing . . 100

40 Assumed Crack Geometry Around Shaft Seal . . . . . 105 
41 Calculated Peak Acceleration at the Surface and Associated

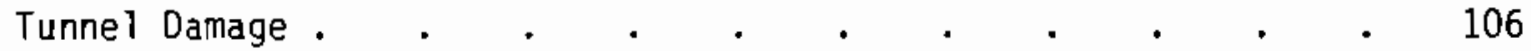

42 Logic Flow Diagram for Deformation $\quad$. . . . . . . . . 111

43 Flow Logic for Faulting in the Sub-Basalt Basement . . . . 112

44 Logic Flow for Shaft Seal Failure Submodel . . . . . . 113

45 Critical and Sensitive Damage Zones for Metorite Impacts . . 119

46 Re lationship Between Crater Diameter (D), Depth of Excavation (d) and Depth of Fracturing $\left(d_{f}\right) \quad . \quad . \quad . \quad . \quad . \quad$.

47 Relationship Between Crater Diameter and Total Impact Kinetic Energy . . . . . . . . . . . . . . 120

48 Logic Flow Diagram for Meteorite Submodel • • . . . . 121

49 Block Diagram of Plutonic and Volcanic Structures . . . . 124

50 Map Showing the Conumbia and Snake River Basalts of

Northwestern United States . . . . . . . . . 126

51 Schematic Diagram of Multiple Flows From Linear Fissures . . . 126

52 Logic Flow for Magmatic Submodel . $1 . \quad$. $\quad$. . . . . 130

53 Potential Consequences Associated with Undetected Features . . 133

54 Sequence of Events Postulated to Explain the Basaltic Ring

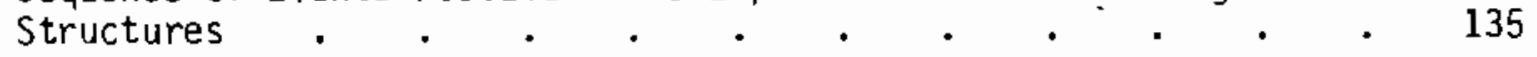

55 Remnant Stream Beds: a) Pre-Flow Conditions, b) During Flow

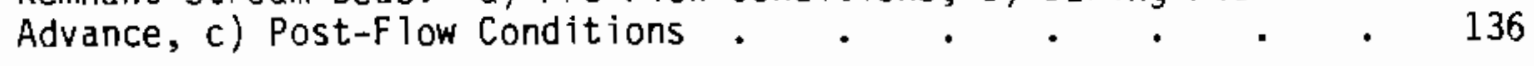

56 Logic Flow for Undetected Features . . . . . . . . 138

\section{$\underline{\text { TABLES }}$}

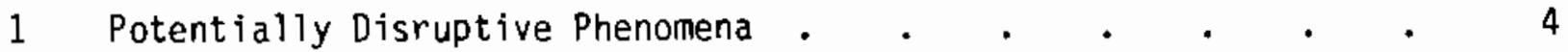

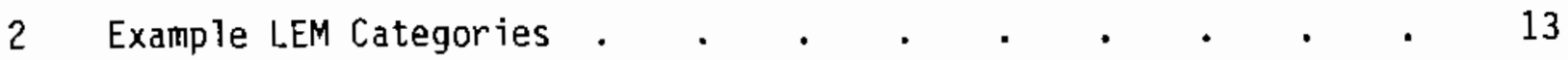

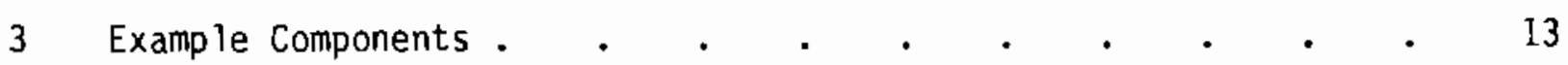

4 Primary Output at Each Time Step for Each Stratigraphic Unit. . 18 
5 Secondary Output at Each Time Step. . . . . . . . . 18

6 Multiple Simulation Output Format . . . . . . . . 20

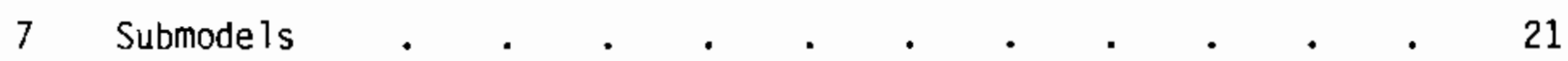

8 Submodel Interaction . . . . . . . . . . . . . . 29

9 Climate Submodel Data . . . . . . . . . . . . . . 39

10 Late Pleistocene $\mathrm{Cl}$ imate Reconstructions Overview of Published

Data . . . . . . . . . . . . 41

11 Age of Glacial Terminations - Summary of Published Estimates . . . . . . . . . . . . . 48

12 Crustal Stresses Associated with Large Ice Sheets . . . 53

13 Continental Glaciation Submodel Data . . . . . . . 63

14 Required and Available Data for the Alpine Glaciation Submodel . 70

15 Potential Ocean Level Variations . . + . . . . 71

16 Sea Level Fluctuation Submodel Data. . . . . . . . . 73

17 Ranges of Average Annual Columbia River Flow . . . . . 75

18 Rates of Regional Erosion in the United States . . . . . 84

19 Geomorphic Events Submodel Data . . . . . . . . . 90

20 Example Bulk Permeabilities for a Joint Rock Calculated From

Parallel Plate Theory . . . . . . . . . 100

21 Reported Seismic Events (M>5.5) Near Hanford Since 1872 . 103

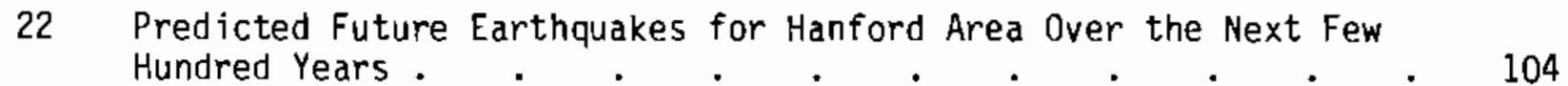

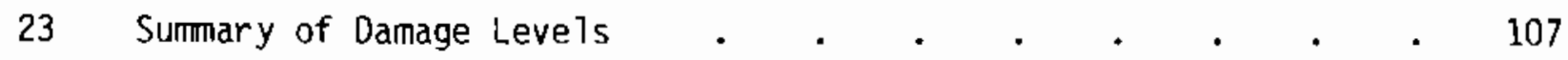

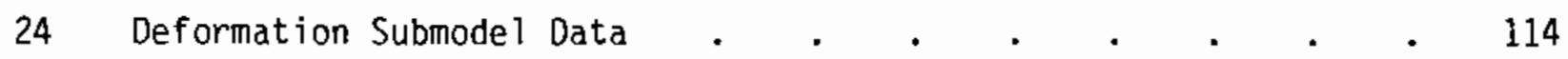

25 Sub-Basalt Basement Fault Data $\quad$. . . . . . . . . . . 115

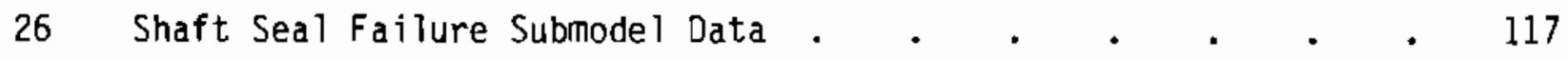

27 Example Parameter Magnitudes for Meteorite Impact _ . . 120 
28 Data Requirements and Availability of Meteorite Submodel . . 122

29 Generalized Classification of Volcanic Activity Based on Approximate Magmatic Compositions . . . . . . . . 125

30 Transport Distances and Eruption Types of Volcanic Events . . 127

31 Magmatic Activity Submodel Data . . . . . . . 131

32 Undetected Features Submodel Data . . . . . . 139 


\section{INTRODUCTION}

The management of potentialiy hazardous radioactive waste products and spent fuels is an integral part of the commercial nuclear energy policy in the United States. Based on this policy, the U.S. Department of Energy (DOE) implemented the National Waste Terminal Storage (NWTS) Program to evaluate alternatives for the safe long-term storage of nuclear wastes. As part of this program, Battelle, Pacific Northwest Laboratory conducted the Waste Isolation Safety Assessment Program (WISAP) under the sponsorship of the Office of Nuclear waste Isolation (ONWI).

The objectives of the Waste Isolation Safety Assessment Program (WISAP) were to: 1) develop the capabilities needed to assess the post-closure safety of geologic repositories, 2) obtain scientifically defensible generic and sitespecific data necessary for safety assessments, 3) provide, as needed, studies to further support these data and analyses, 4) demonstrate the assessment capabilities by performing analyses of reference sites, 5) apply the assessment methodology to assist the National Waste Terminal Storage Program in site selection, and 6) perform repository site analyses responsive to the time schedule and to the level of sophistication required to meet the licensing needs of the National Waste Terminal Storage Program.

There are two basic components of repository post-closure safety assessments:

- identification and analyses of breach scenarios and the pattern of events and processes causing each breach

- identification and analyses of the environmental consequences of radionuclide transport and interactions subsequent to a repository breach.

The Waste Isolation Safety Assessment Program addressed only the far-field, long-term safety of an underground nuclear waste repository. The operational, near-field, and waste-induced portion of the overall safety assessment is being developed for DOE by other contractors through ONWI. 
WISAP was divided into four technical tasks. These tasks were:

- Task 1 - Release Scenario Analysis

- Task 2 - Waste Form Release Rate Analys is

- Task 3 - Release Consequence Analysis

- Task 4 - Sorption/Desorption Analysis

The tasks combine to form the overall safety assessment methodology. The integration of these individual tasks is outlined in Figure 1.

This report is a product of the Task 1 - Release Scenario Analys is research effort. The primary objectives of the task are: 1) analyze the full spectrum of geologic and man-caused phenomena which, alone or in concert, could conceivably lead to the release of radioactive contaminants from the immediate repository boundaries, 2 ) estimate the probabilities associated with any potential "breach" scenarios, and 3) quantitatively bound the initial conditions necessary for a parametric consequence analys is with geosphere and biosphere transport codes. Example phenomena are listed in Table 1.

It is suggested than any safety assessment tool devised to meet these objectives be stochastic in nature and flexible enough to incorporate objective and subjective input from a variety of geoscience disciplines. This conclusion reflects man's limited understanding of natural geologic and hydrologic systems, and the limited data availability.

This report is a conceptual presentation of a methodology entitled Repository Simulation. This simulation approach is a composite of qualitative fault trees, Delphi-like techniques, and Monte Carlo simulation. The userinteractive computer tool is designed to assist geoscientists in identifying and quantifying the various potential geological and hydrological system states in which future repository site might exist.

Although necessarily simple relative to any real geosystem, this computer model reduces a complex, multivariate problem to a set of interrelated but concise components that can be more easily addressed by geoscientists. The key is to focus the efforts of the experts on one segment of the problem at a time within a framework whereby integration of all the components can be achieved. 


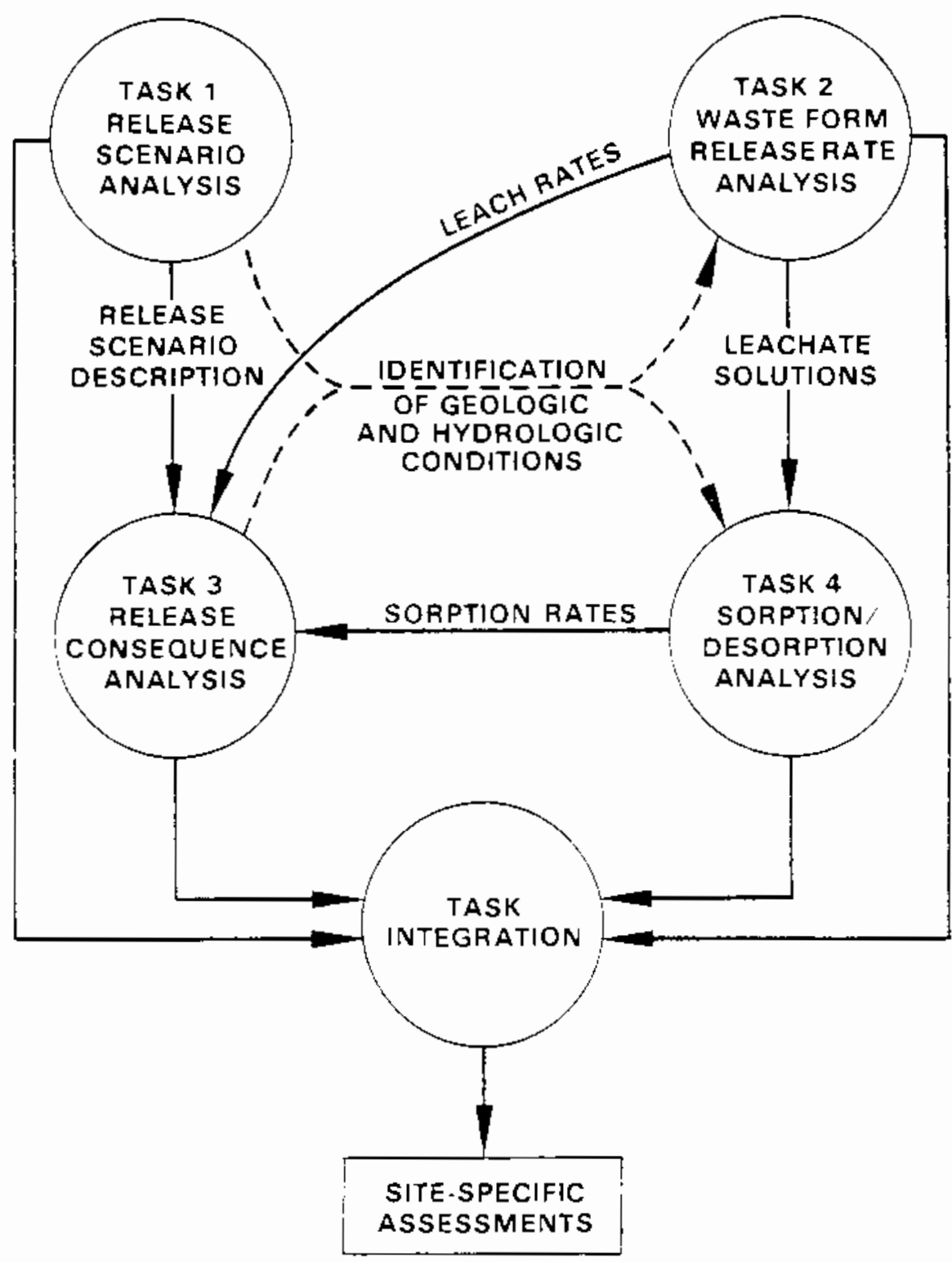

FIGURE 1. Waste Isolation Safety Assessment Program

Reasons for a computer-enhanced methodology include:

1) Significant interaction among disruptive phenomena exists. For example, climate, precipitation, continental and alpine glaciation, erosion, sedimentation, and groundwater recharge are all synergistic in nature. 
2) Most of the disruptive phenomena listed in Table 1 are time dependent and therefore initiation and consequences cannot always be considered simultaneously.

3) Data uncertainties dictate reliance on probability distributions rather than discrete numbers.

4) The sensitivity of the output to variations in the input must be analyzed to help optimize subsequent time and money expenditures.

5) The output of the methodology must be tailored to provide input to the consequence (nuclide transport) analyses. The release scenario

TABLE 1. Example Potentially Disruptive Phenomena

\section{Natural Phenomena}

Climatic Fluctuations

Glaciation

Denuotion and Stream Erosion

Magmatic Activity

- Extrusive

- Intrusive

Epe irogen ic Displacement

- Igneous Emplacement

- Isostasy

Orogenic Diastrophism

- Near Field Faulting

- Far Field Faulting

- Diapirism

Static Fracturing

- Surficial Fissuring

- Impact Fracturing

- Hydraulic Fracturing Meteorites

Dissolutioning

Sedimentation

Flooding

Undetected Features

- Faults

- Breccia Pipes

- Lava Tubes

- Gas or Brine Pockets

- Shear Zones
Man-Induced Phenomena

Improper Design/0peration:

- Shaft Seal Failure

- Improper Waste Emplacement

Undetected Past Intrusion:

- Undiscovered Boreholes or

- Mineshafts

Inadvertent Future Intrusion:

- Archeological Exhumation

- Weapons Testing

- Non-Nuclear Waste Disposal

- Resource Mining (Minera1, Hydrocarbon, Geothermal, Salt, Water)

- Storage of Hydrocarbons or Compressed Air

Perturbation of Groundwater System:

- Irrigation

- Reservoirs

- Intentional Artificial Recharge

- Establishment of Population Center 
task must estimate the input variable ranges for the release consequence task, to provide a basis for parametric consequence studies.

6) The methodology must explicitly reveal the conceptual model of the geoscience users and provide a degree of auditability to the study.

The Release Scenario Analysis Task is designed to address the potential long-term geologic and hydrologic changes that might occur in the vicinity of a high-level waste or spent fuel repository. Although the simulation methodology being proposed is applicable to any desired time frame, emphas is has been placed on the $10^{3}$ to $10^{6}$ years following final closure of the repository. Other studies outside of WISAP will address the operational phase of the facility and the changes in the geohydraulic system that might be induced by the presence of the waste, e.g., fracturing of the host rock due to thermal loading and unloading. It is anticipated that the output of these studies will be used as input to any long-term release scenario analys is.

With respect to long-term studies, it is recognized that approximately 99\% of the projected radioactivity in reprocessed waste will be represented by ${ }^{90} \mathrm{Sr}$ and ${ }^{137} \mathrm{Cs}$, and that these isotopes will decay to innocuous levels after 600 years, or roughly 20 half-lives (Gera and Jacobs 1972). However, certain fission products and selected actinide elements can remain toxic for hundreds of thousands of years if in sufficient concentrations.

The primary output of such a Release Scenario analys is is conceived to be a set of potential future geological and hydrological state descriptions with some estimates of occurrence probabilities. Such system descriptions (hydraulic conductivities, fluid potentials, pathlengths, etc.,) can be used by geosphere/biosphere transport modelers for the purpose of conducting consequence analyses on the predicted breach, if any. For the purpose of this study, a breach is defined as a specific volumetric flux of a potential transport medium through the immediate boundaries of the repository cavity.

To facilitate understanding of the proposed Repository Simulation modeling approach, the Columbia Plateau in the state of Washington is used as a 
hypothetical repository region. However, this report does not represent a preliminary release scenario analysis for this area. As is pointed out in the text, a great deal of additional information is necessary to support such an undertaking. The site-specific nature of the release scenario analysis and release consequence analys is is such that generic applications of the computer codes, although possible, will not be particularly satisfying or enlightening. Site-specific adaptation and use are essential; in this report the Columbia plateau serves as an expedient example.

The primary motivation for the computer methodology is to analyze and present information in a logical and auditable format, to facilitate future discussion, to focus thinking on manageable size segments of the problem, and to provide a flexible framework for incorporating constructive suggestions and criticisms from individuals representing a broad spectrum of backgrounds.

This report is devoted to a description of the Repository Simulation methodology as conceptualized for a hypothetical site in the Columbia Plateau basalts. The information is presented in the form of: 1) theory and diagrammatic flow charts, 2) required input and output tables, and 3) example data distributions.

It must be emphasized that this is not a preliminary safety assessment but, rather, is a conceptual example of how such a Release Scenario study might be conducted. Furthermore, the report is designed as a working document upon which the geoscience community can focus its thinking, direct its criticisms, and channel its suggestions for future evolution of the model and associated data. As such, the framework of the model will necessarily change as a better understanding of the phenomena and their interactions are described by the geoscience community. In this sense, the overall conceptualization of the geologic and hydrologic system represented in this model will evolve as our understanding and knowledge of the local geosystem expands. Hence, the model and submodels discussed within this report should not be considered unalterable and final.

The influence of man and his developing technology is not addressed within the current framework of the conceptualized model described in this report. 
While it is recognized that man could have a significant influence on the geological system, it is extremely difficult to describe the potential system perturbations within the confines of a quantified computer logic. This results from the uncertainty inherent in attempting to describe future courses of man's technological ability. The exact manner of how potential human intervention will be addressed and incorporated in the final safety analys is is still under study.

A description of the overall Repository Simulation methodology is given in the next section. The report then includes discussions on the following topics: 1) climate, 2) precipitation, runoff, and aquifer recharge, 3) glaciation, 4) sea level fluctuations, 5) flooding, sedimentation, and erosion, 6) folding, faulting, jointing, and fracturing, 7) shaft seal integrity, 8) undetected basement faulting, 9) other undetected features, 10) meteorites, and 11) magmatic activity. 


\section{REPOSITORY SIMULATION}

Figure 2 reveals the general logic flow of the Repository Simulation methodology. Basically, it is a brute-force approach with the following five fundamental components: 1) characterization of individual disruptive phenomena, 2) identification of potential interactions, 3) development of a simplified layered earth model, 4) establishment of system response rules, and 5) individual or multiple simulations of the geological and hydrological system. Figure 3 illustrates an example of interrelationships among phenomena and potential synergisms. The bookkeeping component of the Repository Simulation methodology is the Layered Earth Model (LEM) shown conceptually in Figure 4. Tables 2 and 3 present details of the LEM and some illustrative system response rules.

Multiple simulations are necessary to outline the numerous potential geological and hydrological states of the system and to rank them with respect to estimated probabilities. At the end of any given simulation, the system is reinitialized to the state in which the repository resided at time of final backfill and closure.

A breach of the system is defined by a specific volumetric flux of a contaminant transport medium, such as nuclide-bearing water, through the immediate repository boundaries. Note that this requires 1) a pathway, and 2) a difference in hydrautic potential along the path. The model monitors for a breach at the conclusion of each time step during each simulation run. If, during the time step under consideration, either condition is insufficient to support a volumetric flux exceeding a predetermined value, a breach does not occur. This is not to say that both conditions will not be met during subsequent time steps in a simulation run.

At the beginning of any given simulation run, the LEM is initialized to reflect the state of the geologic and hydrologic system at the time of repository backfill. An analogy for the LEM in the one-dimensional model might be a borehole from the land surface down through the repository and all layers above 


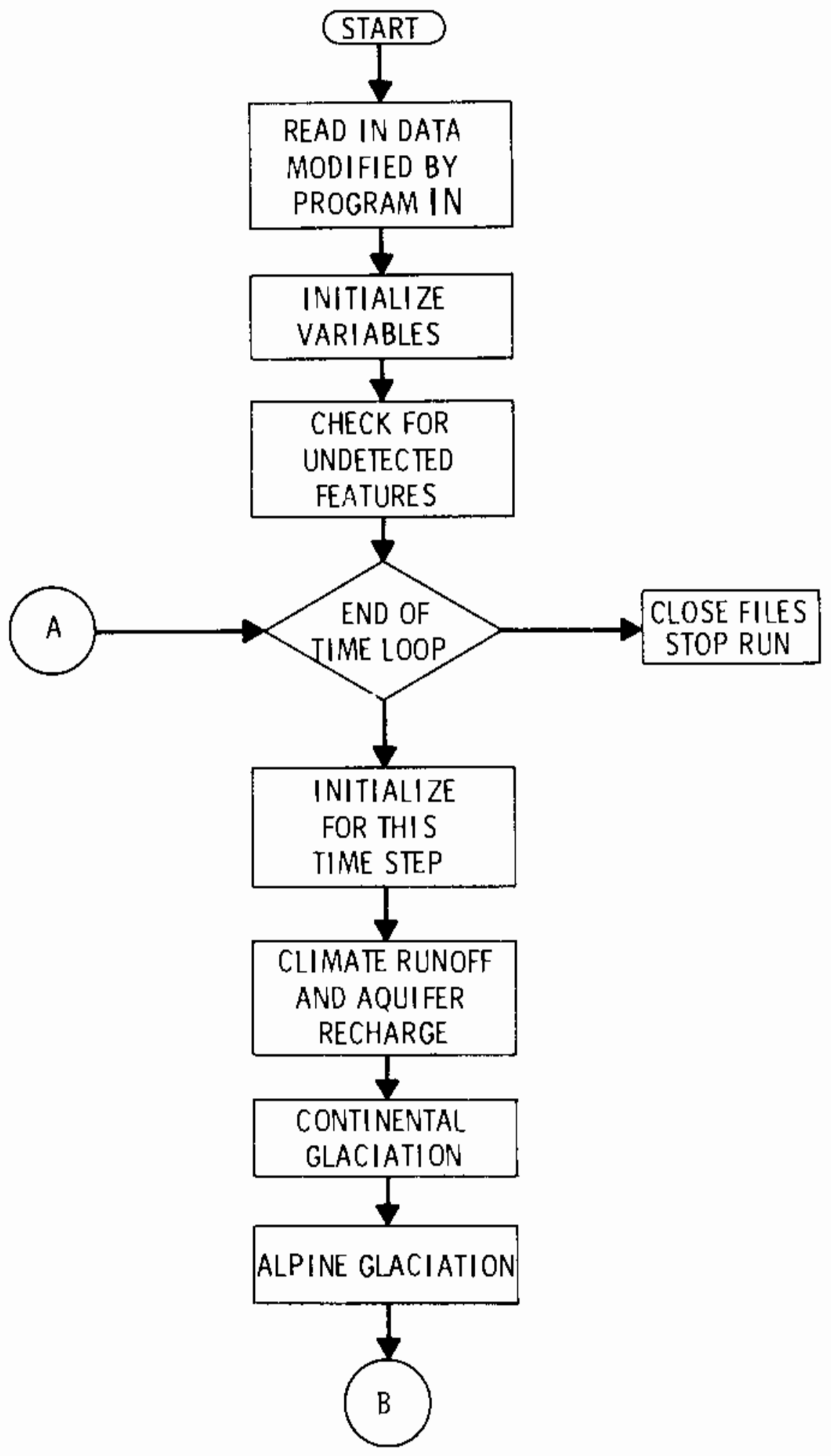

FIGURE 2. Logic Flow Diagram 


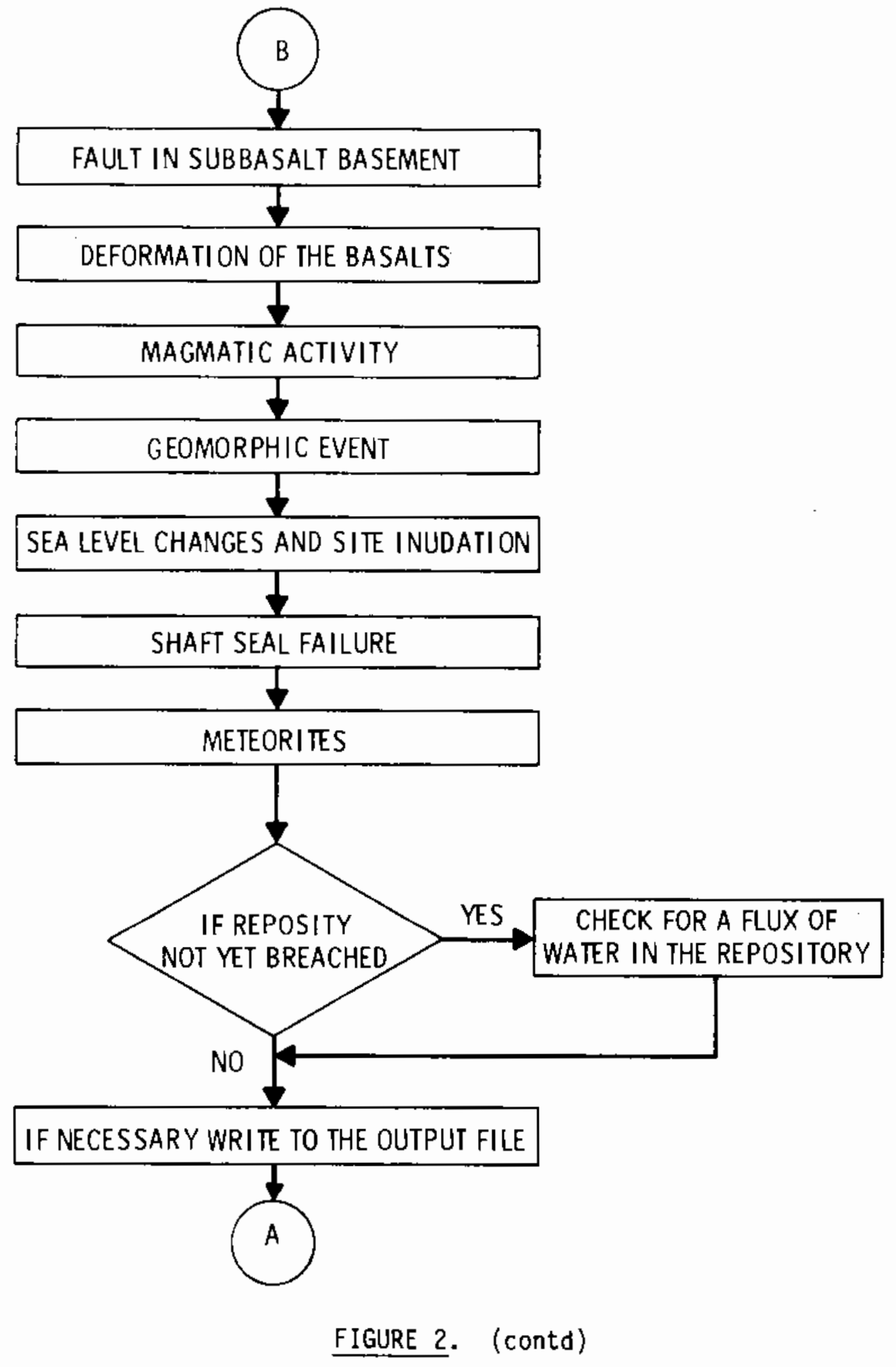




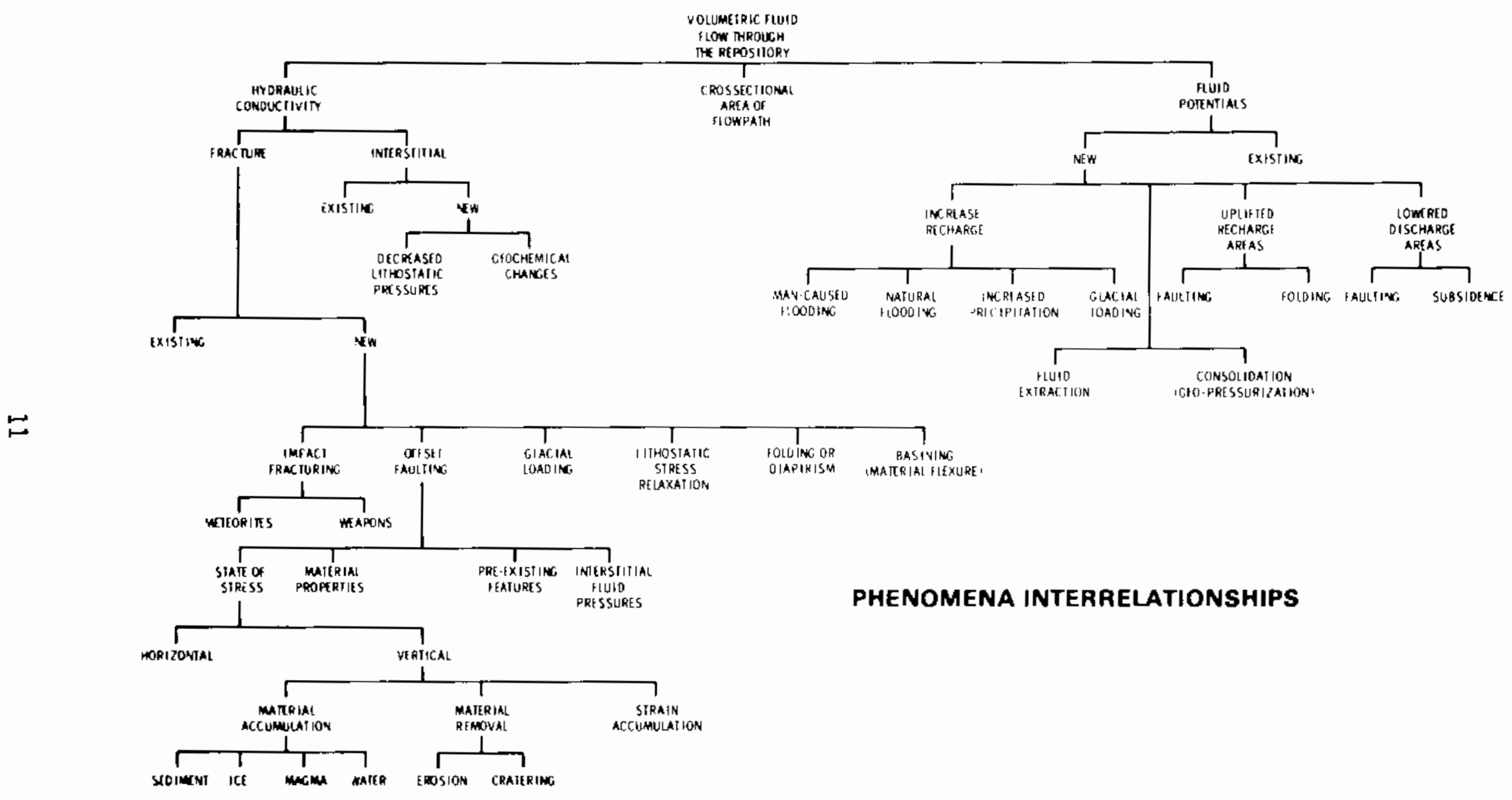

FIGURE 3. Example of Phenomena Interrelationships 


\begin{tabular}{|c|c|c|c|c|c|c|}
\hline & GENERAL LI THOLOGY & $\begin{array}{c}\text { UNIT } \\
\text { NUMBER } \\
\end{array}$ & $\begin{array}{l}\text { LAYER } \\
\text { THICKNESS } \\
\text { (METERS) } \\
\end{array}$ & $\begin{array}{l}\text { HORIZONTAL } \\
\text { PERMEABILITY } \\
\text { (MILLIOARCIES) }\end{array}$ & $\begin{array}{c}\text { VERTICAL } \\
\text { PERMEABILITY } \\
\text { (MILLIDARCIESI }\end{array}$ & $\begin{array}{c}\text { GROUNDWATER } \\
\text { HEADS } \\
\text { MMETERS BELOW SURFACE }\end{array}$ \\
\hline 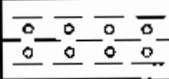 & LOSE SILT SAND AND GRAVEL & 1 & 125 & 2000.0 & 200.0 & 40.0 \\
\hline 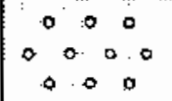 & CEMENTED SAND AND GRAVEL & 2 & 200 & 1000.0 & 100.0 & 40.0 \\
\hline 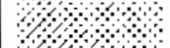 & BASALT & 3 & 300 & 0.13 & 0.13 & 52.0 \\
\hline & SEDIMENTARY INTERBEO & 4 & 25 & 300.0 & 30.0 & 43.0 \\
\hline & BASALT & 5 & 250 & 0.013 & 0.013 & 55.0 \\
\hline & SEDIMENTARY INTERBED & 6 & 25 & 1330.0 & 133.0 & 43.0 \\
\hline & BASALT \{REPOSITORY\} & 7 & 100 & 0.013 & 0,013 & 52.0 \\
\hline & SEDIMENTARY INTERBED & 8 & 25 & 1330.0 & 133.0 & 44.0 \\
\hline & BASEMENT & 9 & $\infty$ & 0.013 & 0.013 & 61.0 \\
\hline
\end{tabular}

\section{FIGURE 4. Example Layer Earth Mode1}

and below it. Vertical averaging of a real geosystem should reduce the number of layers to ten or less, with biasing toward those layers closest to the repository.

Each stratigraphic unit represents a spatially uniform cell to which a variety of geological, hydrological, and chemical data can.be associated. Of primary interest are: 1) the thickness of the layer; 2) vertical and horizontal hydraulic conductivities; 3) vertical and horizontal hydraulic gradients; 4) effective stresses; 5) the lateral distance down any given layer to a discharge point to the biosphere (e.g., lake, river, aquifer), and 6) a "shortcircuit" (fault zone, breccia pipe, or ring structure) to another layer.

At the end of each time step in the simulation, these characteristics of the LEM are updated based on how the ongoing scenario processes (erosion, glaciation, faulting, etc.) perturb the system. A fundamental assumption is that the order of updating within a single time step is not significant. In other words, the LEM characteristic may lag the ongoing processes or disruptive events by as much as one time step. If these steps are relatively small, e.g., $10^{2}$ or $10^{3}$ years, this necessary assumption should have no significant effect. 
TABLE 2. Example LEM Categories

Dimensional Characterization

Number of layers

Relative height and thickness

Spatial coordinates

Anomalies

Faults

Shear zones

Breccia pipes

Lava tubes

Wells and boreholes

General Hydrologic Parameters

Topography and drainage

Hydraulic potentia!s

Hydraulic conductivities

Recharge and discharge

1. Natura?

2. Man-caused

3. Areal extent

4. Elevation

State of Effective Stress

Rock Properties

Porosities and permeabilities

Strength characteristics

Elastic properties

Inelastic properties

Thermal properties

Inhomogeneity and Anisotropy

Valuable Resources

Minerals

$0 i 1$, gas

water

Back-fill Material Characteristics

Relative to Host Rock Formation

Density

Compressibility

Acoustic Impedance
TABLE 3. Examp le Components

Disruptive Phenomena Data

Occurrence probabilities

Rate

Magnitudes

Phase data (lag time)

Layered Earth Model

Number of layers

Thickness of the layers

Mechanical and chemical properties

Hydraulic conductivities

Hydraulic potentials

State of effective stress

Example System Response Rules

North American climate related to orbitral parameters and atmospheric dust load

Denudation is related to climate, elevation differences, and rock properties

Glaciation may result in erosion, fracturing, and recharge

Fault rupture effects hydraulic conductivities and potentials

Overburden accumulation may change the state of effective stress, porosities, and permeabilities.

Increased precipitation may affect aquifer recharge, water table elevation, and erosion

Breach Interrogation and Input to Consequence Analys is

Breach is defined by a specified volumetric flux of a fluid through the immediate cavity boundaries

Input to consequence analys is includes: scenario probability simulated time, and layered earth model description 
Figures $5 \mathrm{a}$ through $5 \mathrm{~d}$ present the concept of system perturbation, breach, and failure through a hypothetical scenario. The first diagram shows the repository at time zero (backfi11). At year $10^{\mathrm{N}}$ the system has been perturbed by erosion, possible pressurized glacial recharge of the deep aquifers, and river course alteration. However, the low permeability of the host basalt maintains the isolation integrity of the system. Thus we have only a perturbation, i.e., some system characteristics have changed but no breach has occurred. At year $10^{\mathrm{N}+\mathrm{M}}$, faulting in the basement strata or anticlinal deformation near the site has induced shear displacement on the joints in the host basalt layer. Associated enhancement of the vertical permeability results in creation of a continuous path from an underlying aquifer through the repository to an overlying aquifer. The fiuid potentials or hydraulic heads are such that a small flow is created in a downward direction. Thus a breach has occurred and transport codes can be used for the consequence analysis. Data such as time of the breach, hydraulic conductivities, hydraulic gradients, and distance to the irrigation wells and the river are given to the transport modelers as input conditions. A failure occurs only if the output of the consequence models show unacceptable contamination of the biosphere. In other words, the "breach" need not lead to a "failure." Note, however, that in year $10^{N+M+L}$, renewed glaciation has perturbed the flow conditions by increasing the head in the aquifer below the repository (layer $G$ in Figure $5 d$ ) by wet based ice loading of the distant recharge areas. The upper aquifer is not so affected. Alternatively, increased pumping from the upper aquifer (layer $E$ in Figure 5d) has reduced the head and, therefore, flow is now going from the lower aquifer through the fractured repository zone to the upper aquifer and toward another discharge point along a different path. Once again the transport codes would be exercised to address the potential consequences to the biosphere. Note, however, that the original fracture zone may have "healed" or closed due to secondary mineralization or creep closure, and thus no breach would exist.

One can envision the large number of potential scenarios that can be generated by such speculation. Thus, two modes of computer operation will be available: 1) the user-oriented, interactive-graphical mode where the geoscientist selects his own disruption phenomena combinations and associated magnitude, rate, and delay time data; and 2) a Monte Carlo mode. 


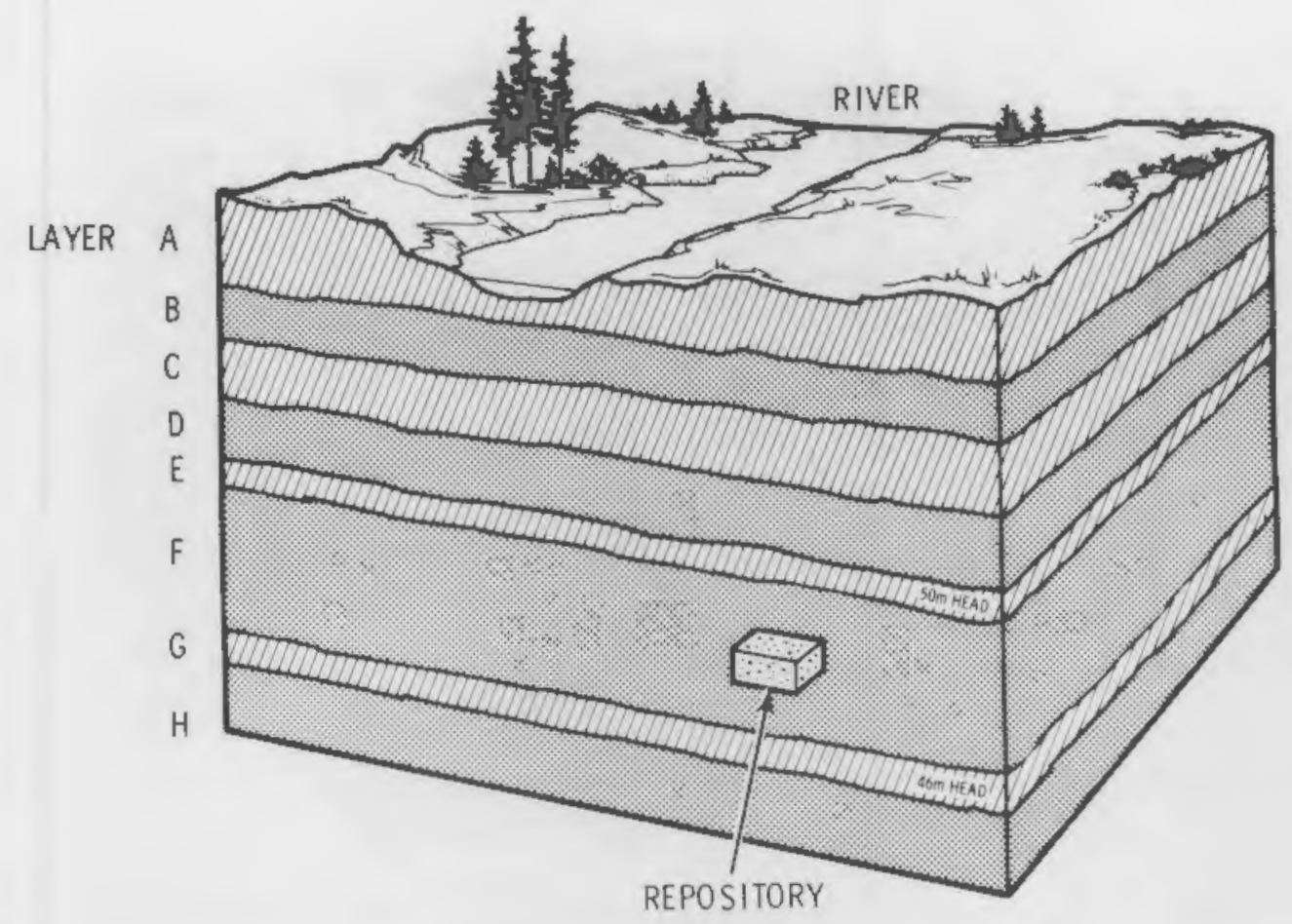

FIGURE 5a. Initial System State Time $=0$ Years

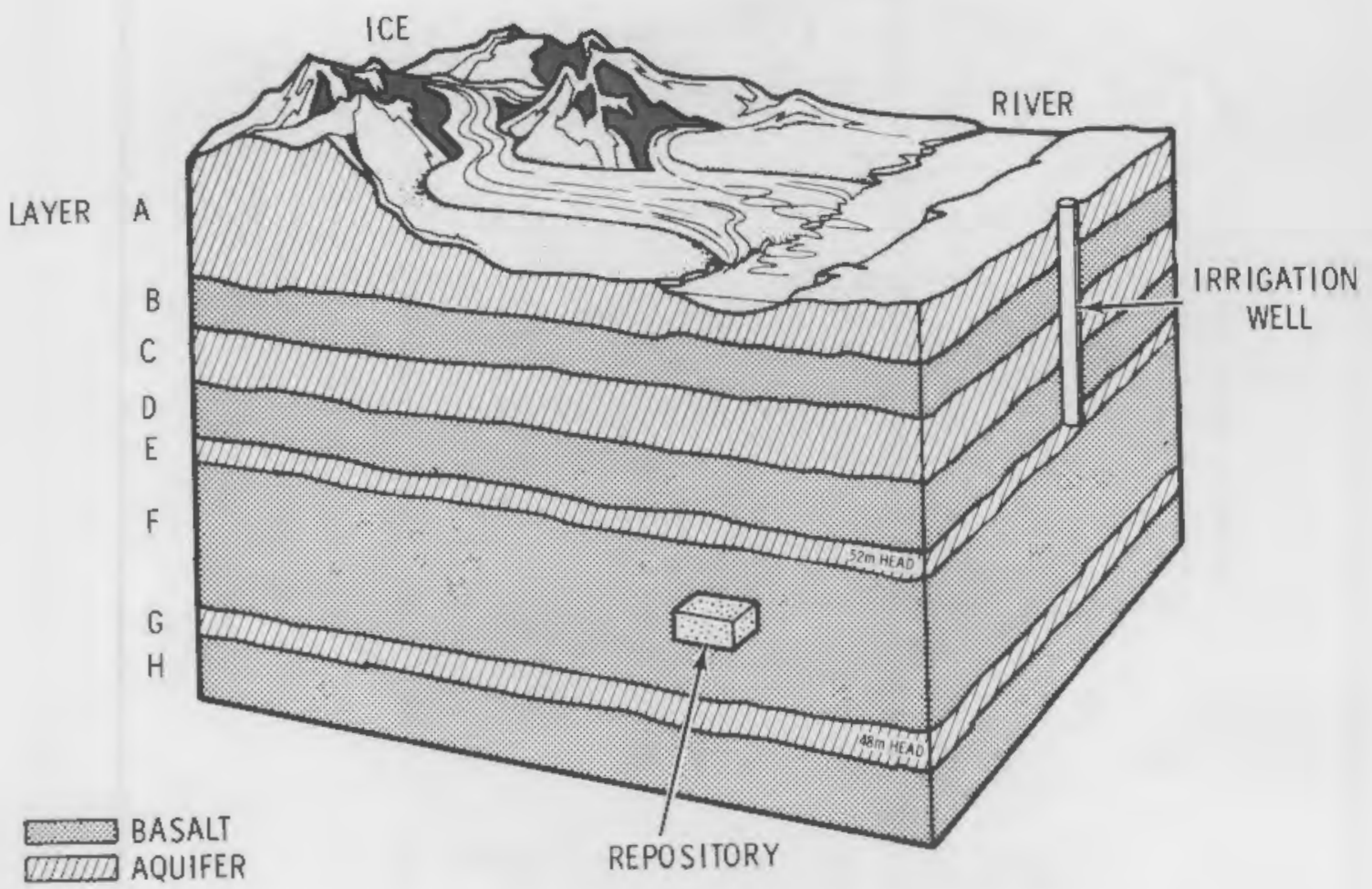

FIGURE. 5b. System Perturbation Time $=10^{\mathrm{N}}$ Years 


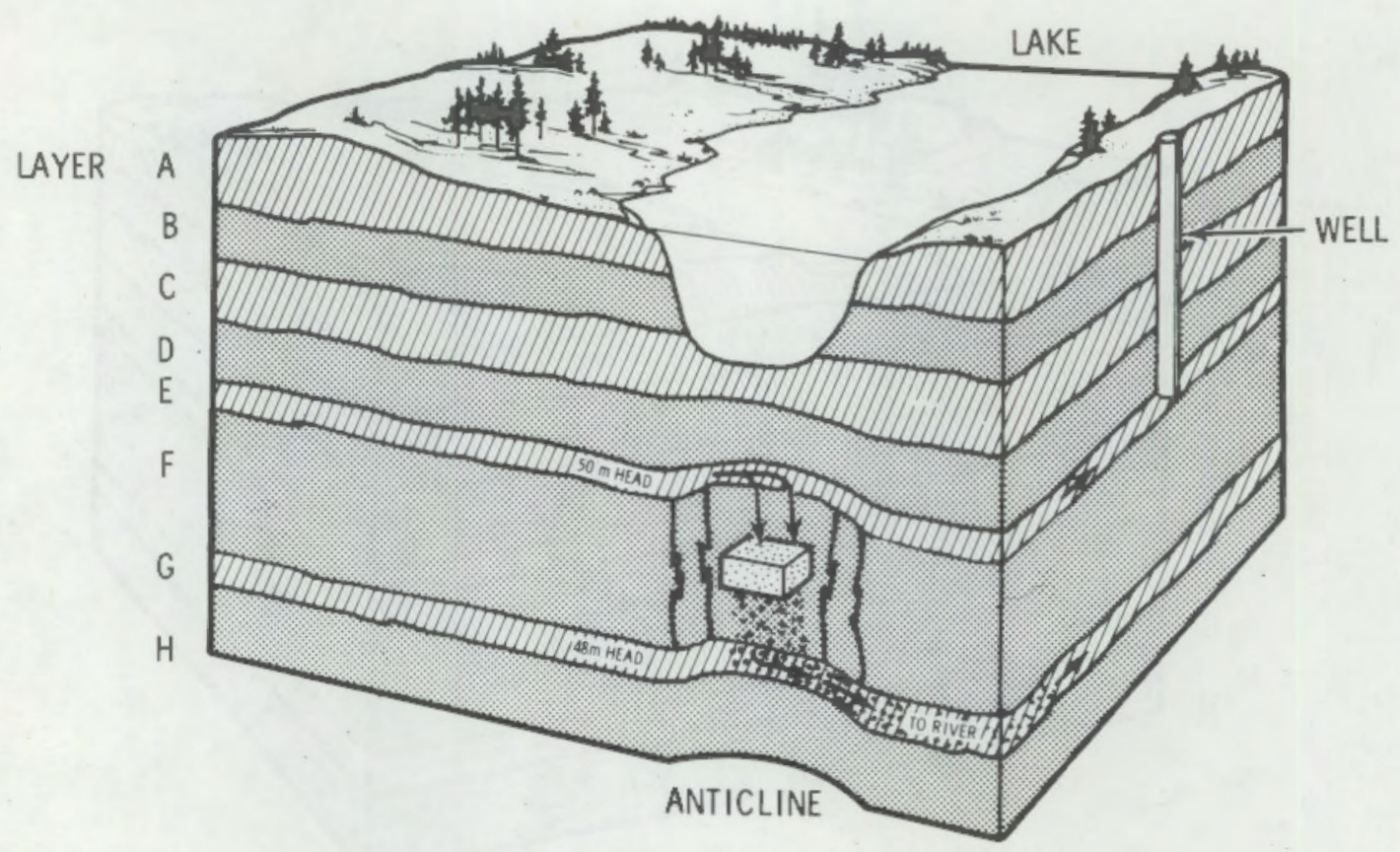

FIGURE 5c. Breach (Potential Failure) Time $=10^{\mathrm{N}+\mathrm{M}}$ Years

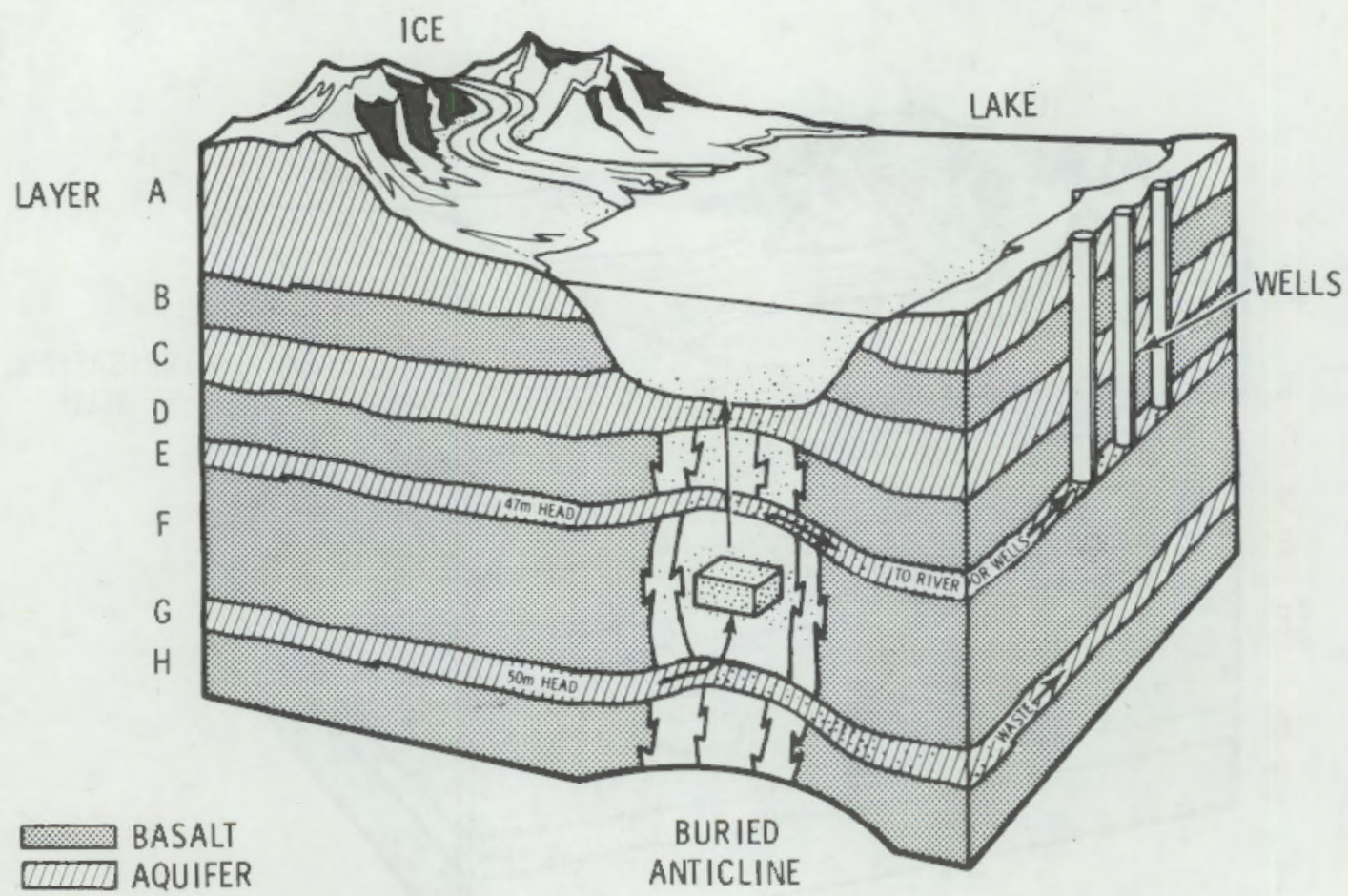

FIGURE 5d. Failure Time $=10^{N+M+L}$ Years 
In the interactive mode, users select their own scenarios and data from the supplied distributions. In this manner, they can conduct parametric analysis rapidly and efficiently and examine coupling phenomena in increasing levels of detail. The variations in the system with time and the chosen phenomena can be observed by following the characteristics of the layered earth model. These characteristics are updated at the end of each time step, e.g., 100 or 1000 years.

In the Monte Carlo mode, the computer will automatically combine disruptive phenomena into scenarios based on relative occurrence probabilities, select data from the supplied distributions, and scan for a breach at the end of each time step. If a breach is manifested, description of the breach and the geohydrological system at that time step is then fed to the hydrological and nuclide transport models so that the consequences for the biosphere can be quantified. Tables 4 and 5 list the output parameters which are indexed according to stratigraphic unit and simulated time. At the end of any given time step or subsequent to the completion of any scenario (case history), the operator can interrogate the data files for a partial or complete description of the layered earth model. Additionally the operator can examine a history file which contains information on any significant features, e.g., faults, which occurred during the time step. Table 6 shows conceptually how multiple simulations from a Monte Carlo run can be presented. In this example, the operator is interested in only the first $10^{4}$ years in multiple $10^{6}$ year simulations. Such a table would represent the various states in which the repository might exist by year 10,000. The breach column of Table 6 indicates whether or not the particular state characteristics have resulted in a specific volumetric flow of a transport fluid through the immediate repository boundaries.

It is possible to arbitrarily select a breach at some specific point in time and conduct hydrologic and nuclide transport calculations based on existing geological or hydrological conditions. The input to the consequence analysis (e.g., pathlengths, hydraulic conductivities, hydraulic gradients, and sorption coefficients) must be altered to observe the variations in the output. 
TABLE 4. Primary Output at Each Time Step for Each Stratigraphic Unit

- Hydraulic conductivity (vertical and horizontal)

- Fluid Potentials (vertical and horizontal)

- Effective Stresses (vertical and horizontal)

- Layer Thickness

- Elevation of Surface

- Breach Status

- Breach Description, if any

- Pathlengths along discrete vertical and horizontal legs

- Conductivities along the flow paths

- Potential gradients along the part

- All associated probability information

TABLE 5. Secondary Output at Each Time Step

Submode 1

Climate

Continental Glaciation

Alpine Glaciation

Geomorphic Events
Output

Climatic State

Recharge

Precipitation

Major Stream Flows

Status

Ice Scouring

Incremental River Flow

Pressurized Recharge

Incremental Facture Permeability

Incremental Sub-basal Groundwater Flow Isostatic Effects

Ablation Melt Water

(similar to Continental)

Stream Erosion

Denudation

Sedimentation

Coordinate Variations in Recharge and Discharge Points

"Missoula" Type Flooding 
Table 5. (contd)

Submode 1

Sea Level Fluctuations

Deformation

Sub-Basalt Faulting

Shaft Seal Failure

Undetected Features

Meteorites

Magmatic Activity
Output

Elevation Relative to Site Incremental Changes in Hydraulic Gradients

Erosion or Sedimentation

Vertical Recharge

Groundwater Table Elevation

Distance from Undetected Feature

Incremental Permeability due to Lateral Fault Extension

Degradation of Permeability due to Healing

Incremental Permeability due to Shear Displacement on Joints

Incremental Permeability

Type (Normal, Reverse, Strike slip)

Width, Length, Displacement

Peak Acceleration, Velocities, Frequencies, Duration, and Attenuation

Stress Change

Incremental Permeability

Dimensions

Type

Location

Incremental Permeability

Crater Depth

Fracture Depth

Incremental Permeability

Seismic Energy Release

Distance from Site Material Dispersed to Air Material Dispersed to Surface Water Material Exposed to Ground Water 
TABLE 6. Multiple Simulation Output Format

PRIMARY OUTPUT

FOR MULTIPLE SIMULATIONS

Time $=10^{4}$ years in a $10^{6}$ year simulation

Layer $=8$ (contains repository)

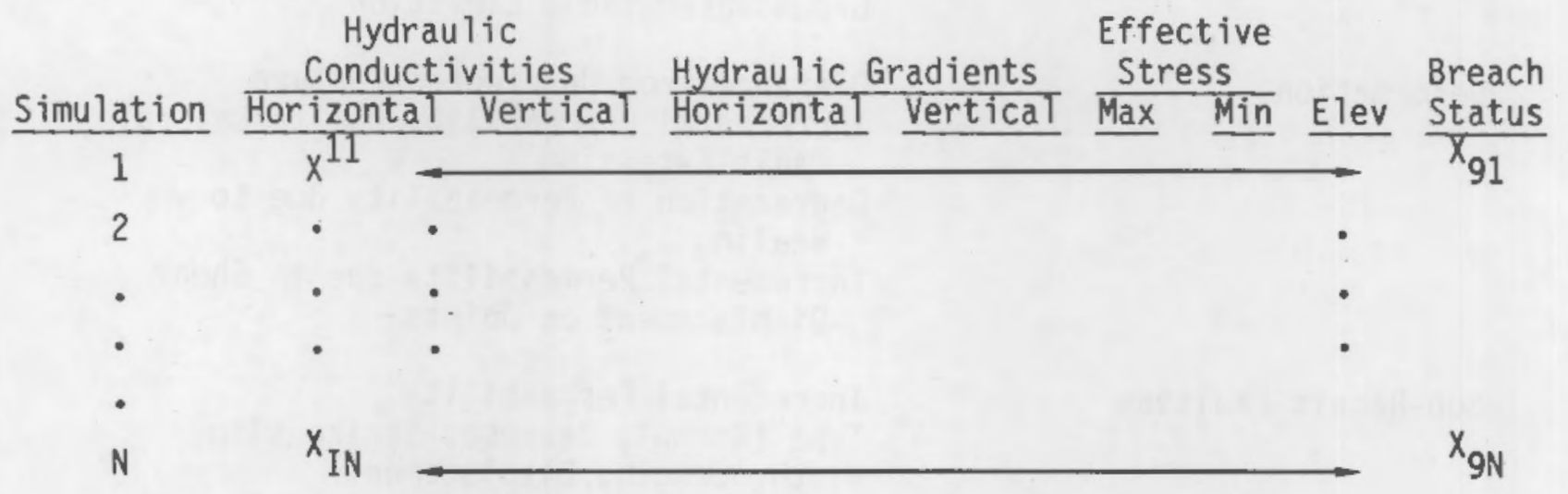

Mean $X$

Variance $\sum_{j=1}^{N} \frac{\left(x_{i j}-\bar{x}\right)^{2}}{N}$

The Repository Simulation methodology is designed to assist in this parametric consequence study by bounding the perturbations one must place on the input parameters used in the numerical transport models. 


\section{EXAMPLE SUBMOOELS}

Table 7 lists the various submodels discussed in this report. These models are presented in the following format:

- block diagrams revealing submodel interactions and anticipated effect on the four fundamental LEM variables (pathlengths, hydraulic conductivities, fluid potentials, and effective stress)

- logic diagrams detailing the components of each submodel

- data requirements

- desired output.

Figures $6 \mathrm{a}$ through $6 \mathrm{e}$ are block-tree diagrams that illustrate submodel interaction. A tabular listing of the submodel interactions is shown in Table 8. The components of each submodel will be highlighted in the remainder of this report.

The information presented is based upon a hypothetical site in the Columbia Plateau Basalt region of Washington State. Figure 7 shows the geographic characteristics of this Pacific Northwest region. Figures 8 and 9 present the general geomorphology and cross sectional characterization of the hypothetical site. It is assumed that the repository site encompasses $10 \mathrm{~km}^{2}$ and is surrounded by a $100 \mathrm{~km}^{2}$ sensitivity zone. For the purpose of this report, the hypothetical site is assumed to be beneath Battelle, Pacific Northwest Laboratories. This hypothetical site was chosen because of the relative amount of data available and currently being generated by the Basalt Waste Isolation Program, and also because of the research staff's proximity.

\section{TABLE 7. Submodels}

Climate

Continental glaciation

Alpine glaciation

Sea level fluctuations

Geomorphic events

Deformation
Sub-basalt basement faulting

Shaft seal failure

Undetected features

Magmatic activity

Meteorites 


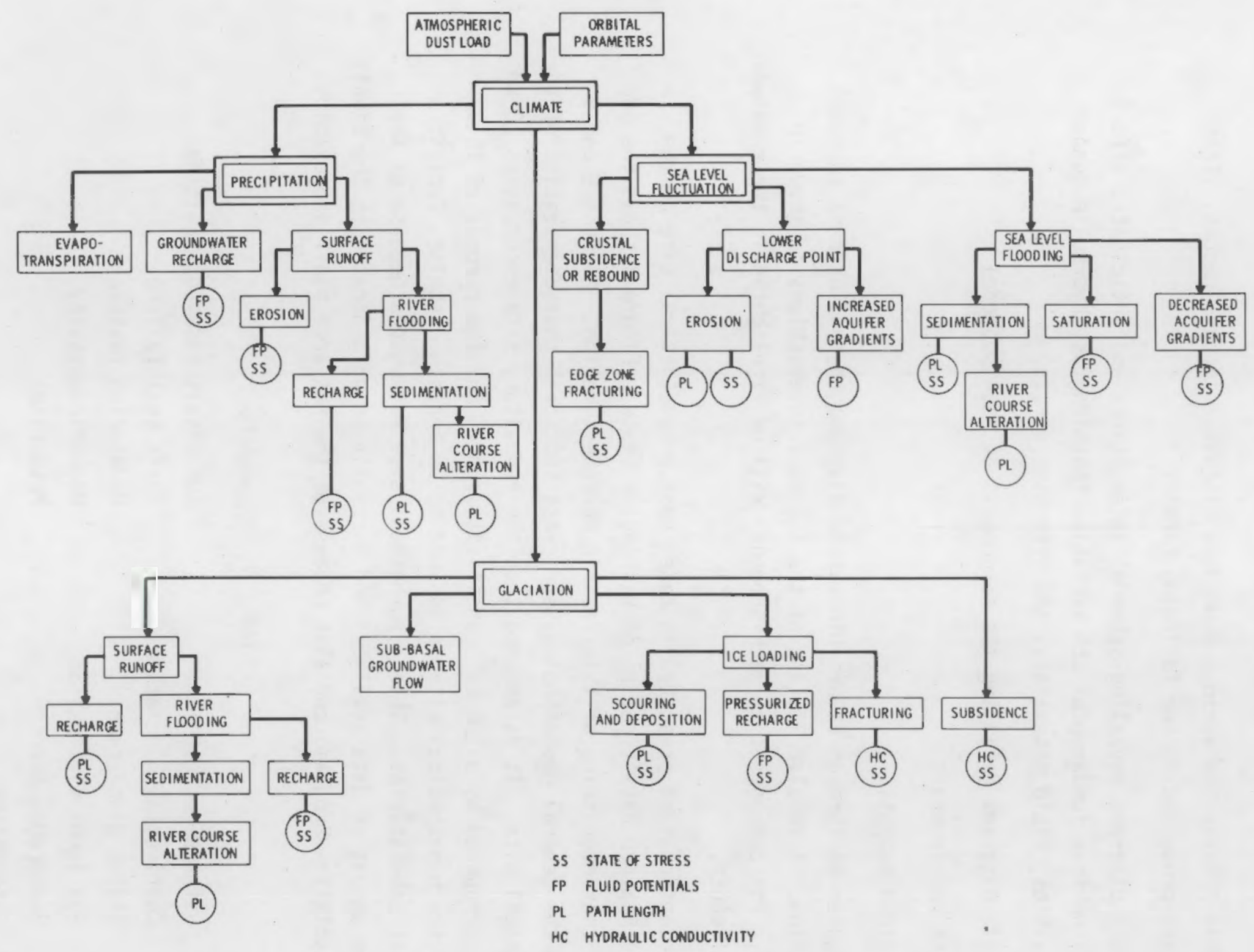

FIGURE 6a. Submode1 Block Diagrams 


\section{FRACTURING}

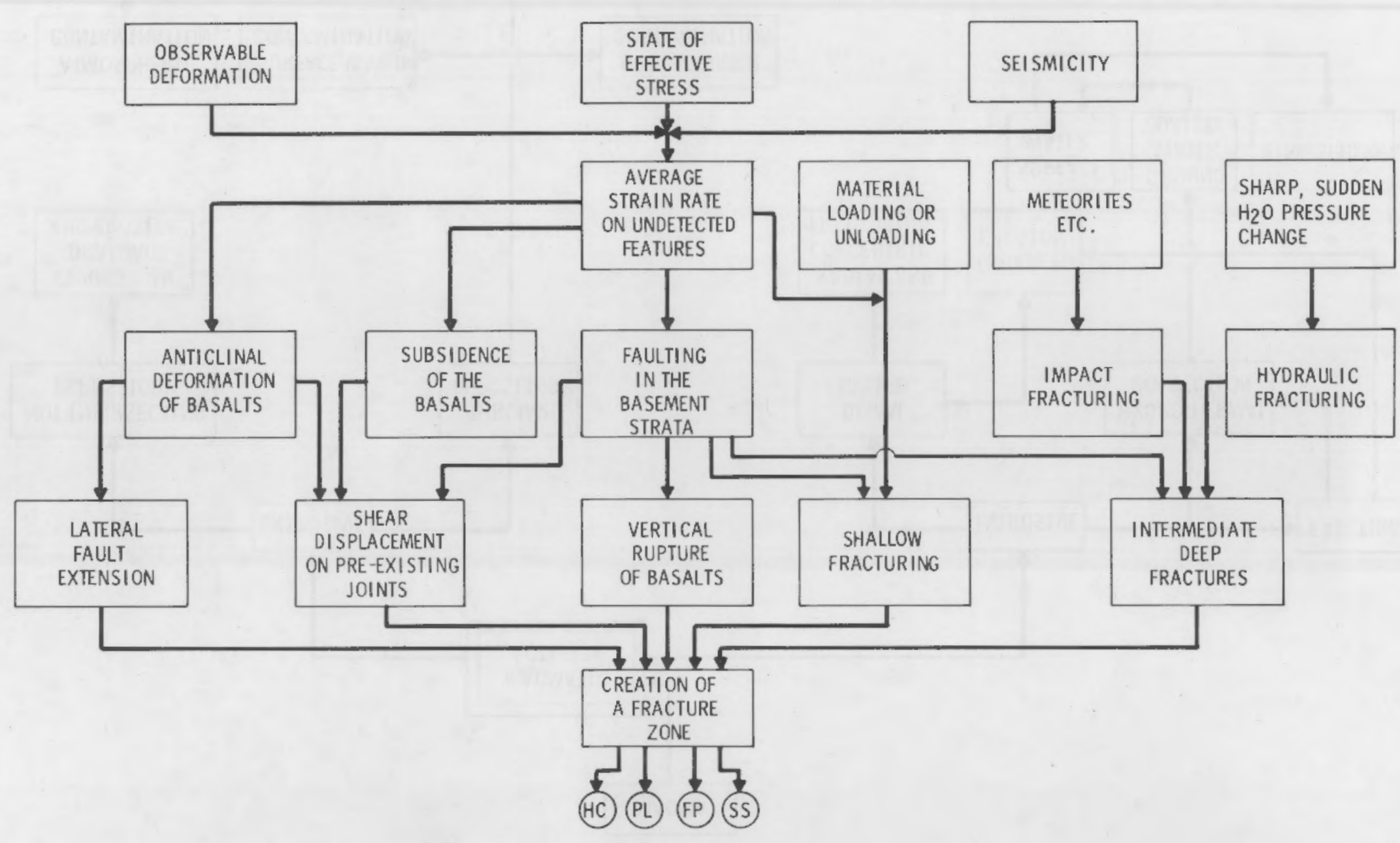

FIGURE 6b. (contd) 


\section{MAGMATIC ACTIVITY}

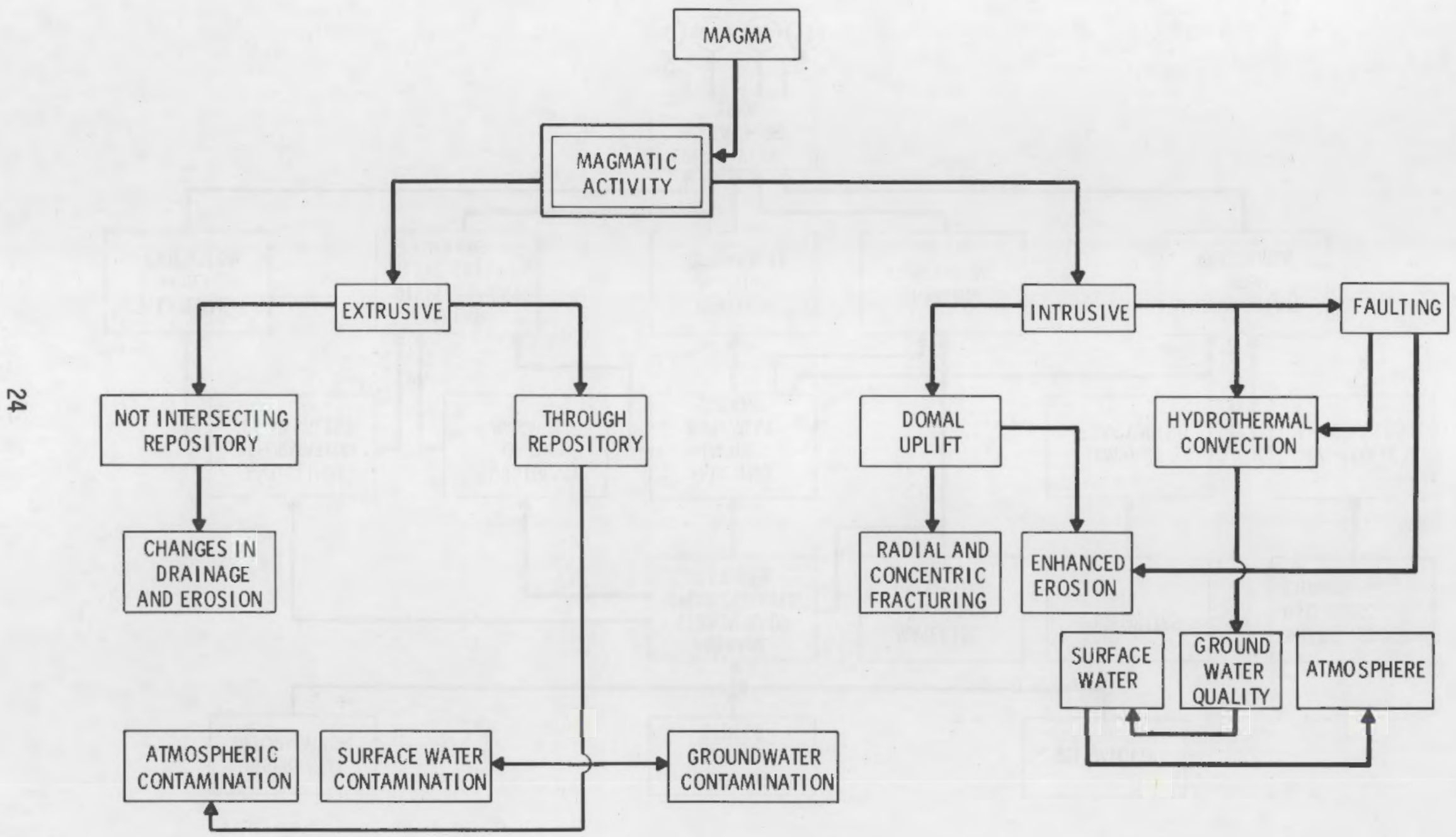

FIGURE 6c. (contd) 


\section{METEORITES}

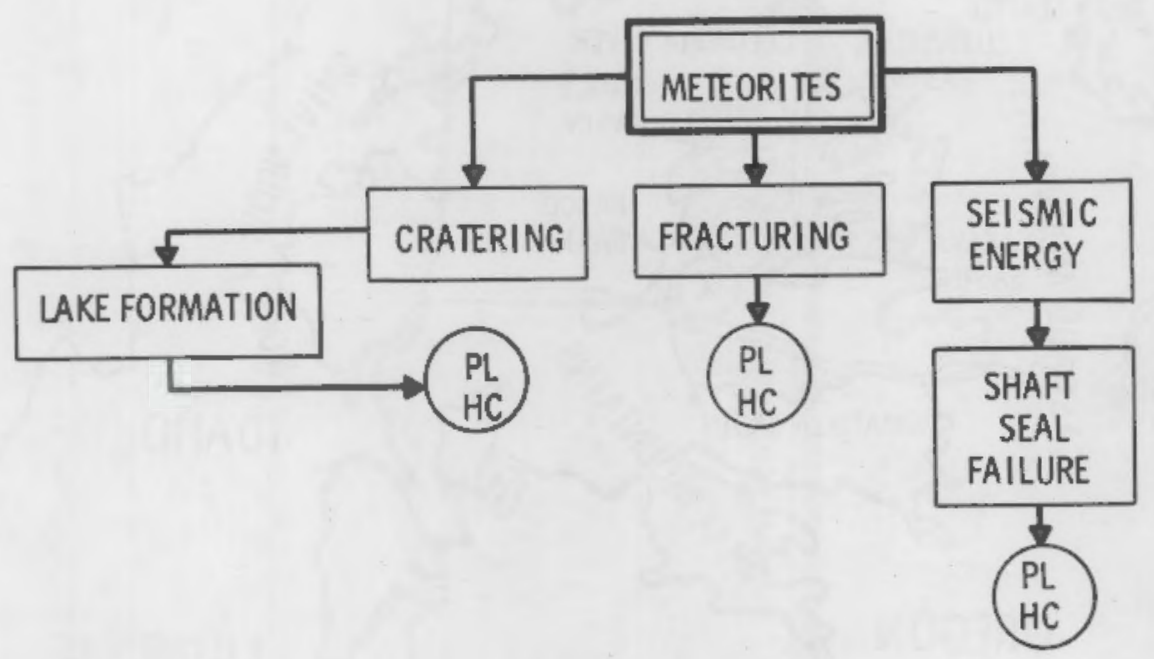

FIGURE 6d. (contd)

\section{EXAMPLE \\ UNDETECTED FEATURES}

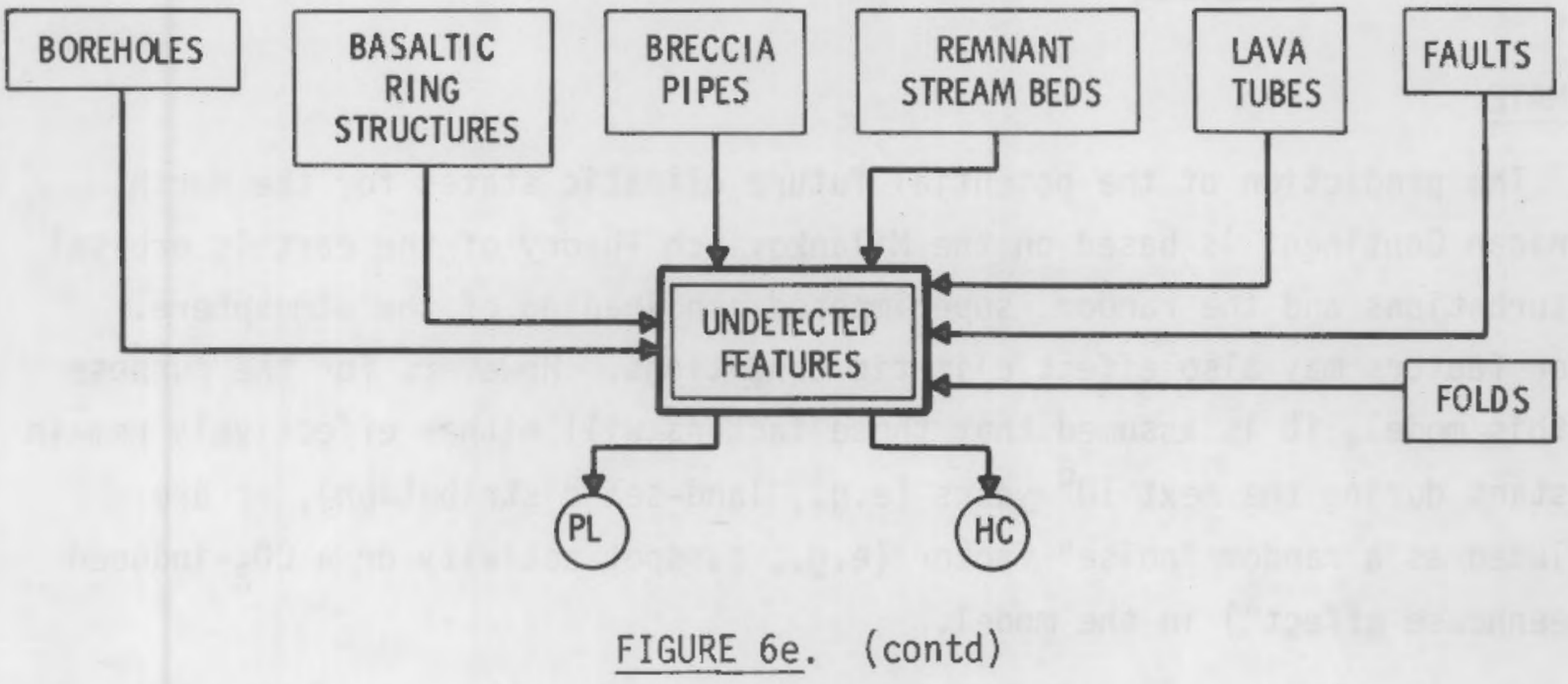




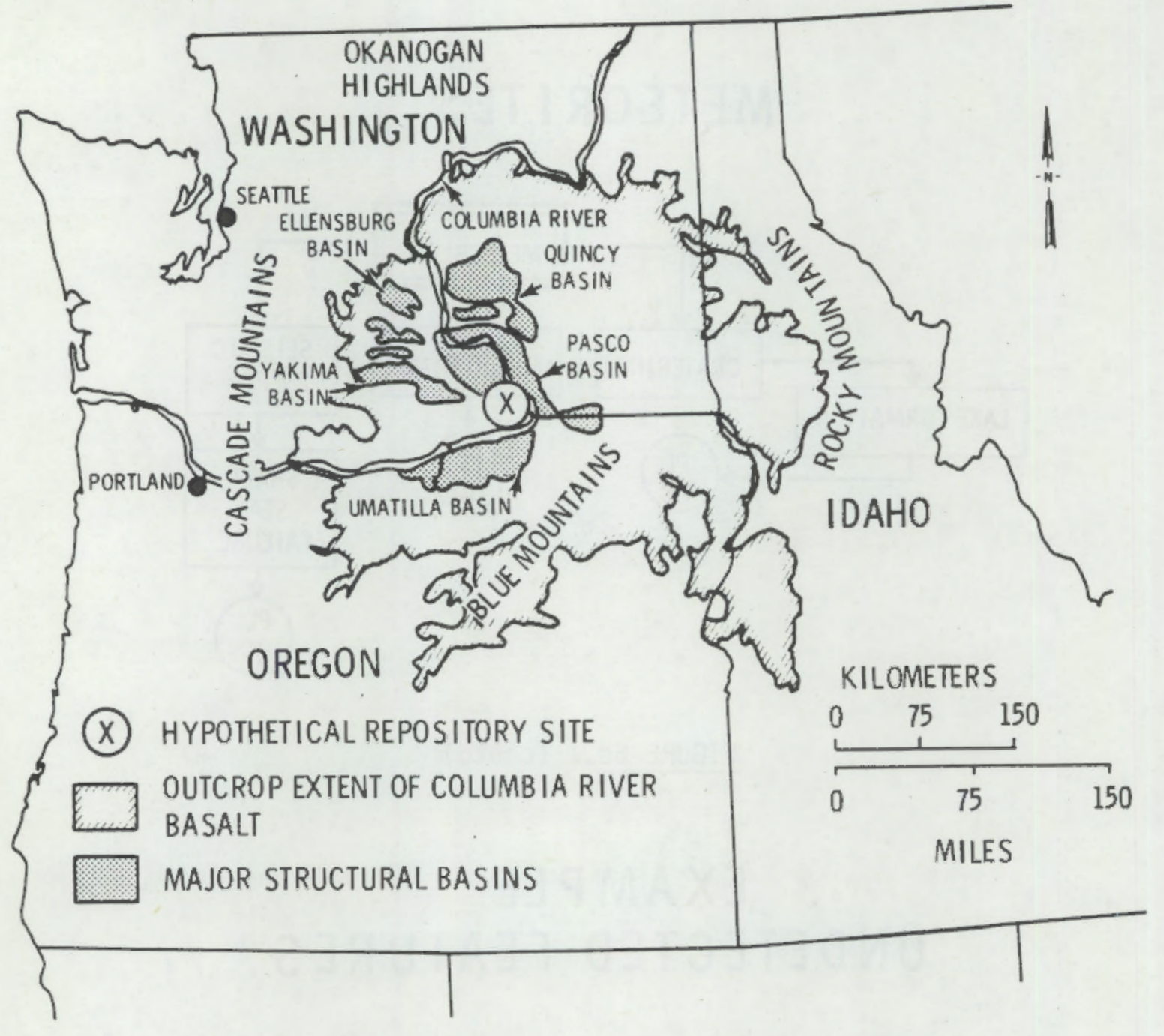

FIGURE 7. The Columbia Plateau (RH0-BWI-78-100)

\section{CLIMATE}

The prediction of the potential future climatic states for the North American Continent is based on the Milankovitch Theory of the earth's orbital perturbations and the random, superimposed ash loading of the atmosphere. other factors may also affect climatic conditions. However, for the purpose of this model, it is assumed that these factors will either effectively remain constant during the next $10^{6}$ years (e.g., land-sea distribution), or are included as a random "noise" factor (e.g., sunspot activity or a $\mathrm{CO}_{2}$-induced "greenhouse effect") in the model. 


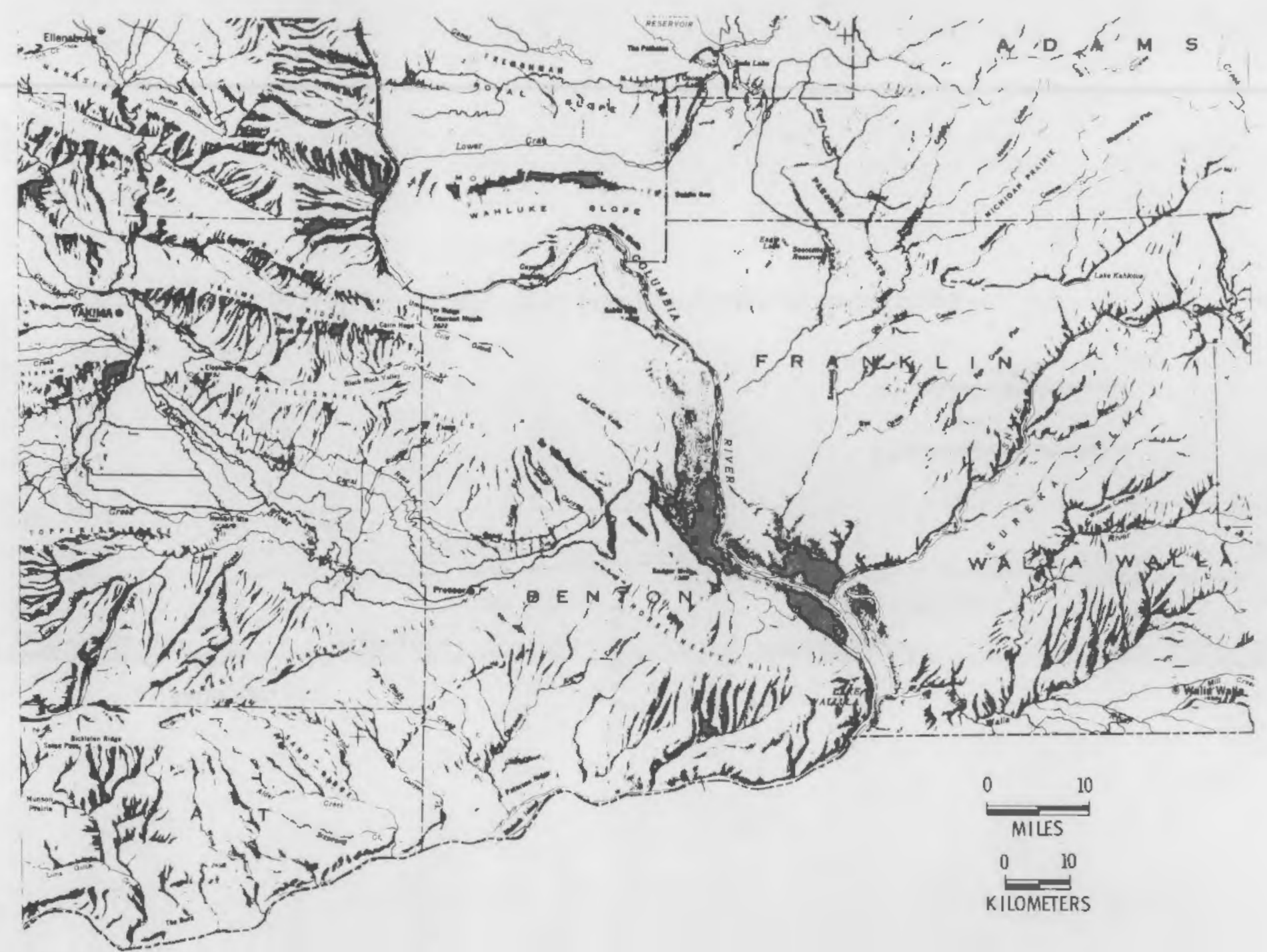

FIGURE 8. Major Topographic Features (RH0-BWI-78-100) 


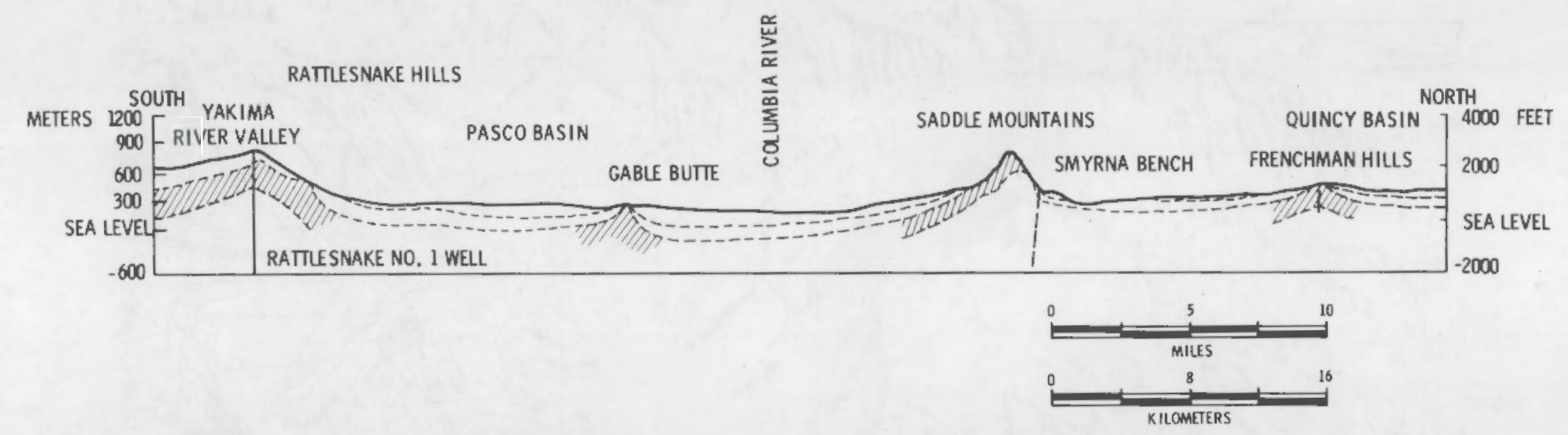

FIGURE 9. Simplified Cross-Section of Study Area 
TABLE 8. Submodel Interaction

\begin{tabular}{|c|c|c|c|c|c|c|c|c|c|c|c|}
\hline IT Le & CONT. GL & Fault & FOLO & EROSION & MAGMA & ALP. GL. & UNDETECT & SEA & CLIMATE & METEOR & SHAFT \\
\hline CONT. GL & 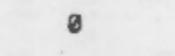 & 0 & 1 & 1 & 1 & 1 & 0 & 1 & - & - & 1 \\
\hline FAULT & - & $a$ & 1 & - & $\emptyset$ & 0 & a & 1 & 0 & 0 & 1 \\
\hline POLO & - & 0 & 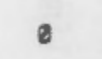 & 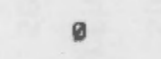 & 0 & 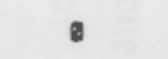 & 0 & 1 & 0 & a & 1 \\
\hline EROSION & - & 0 & - & 0 & 1 & 0 & - & 1 & - & - & - \\
\hline MAGMA & - & - & 0 & 1 & 0 & - & 0 & 1 & - & - & 0 \\
\hline ALP. GL. & - & 8 & e & 1 & 1 & 0 & 0 & 1 & 0 & 0 & - \\
\hline UNDEPECT & - & 1 & 1 & 0 & - & 0 & 0 & - & - & 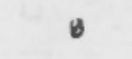 & 1 \\
\hline BEA & - & 0 & - & 1 & 1 & 0 & - & 0 & - & - & - \\
\hline CLIMATE & 1 & 8 & - & 1 & - & 1 & 0 & - & - & 0 & - \\
\hline METEOR & - & - & 0 & 0 & 1 & 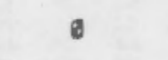 & - & 1 & - & - & 1 \\
\hline SHAFY & - & - & 0 & - & 0 & 0 & - & - & 0 & 0 & 0 \\
\hline
\end{tabular}


Four climatic states are considered:

1) Interglacial: global climates not significantly different from the present, or possibly warmer.

2) Temperate Interstadial: global climates cooler than at present, but generally mild.

3) Interstadial: global climates significantly cooler than at present; northern mid-latitudes close to glacial mode.

4) Stadial (Full Glacial): global climates harsh and cold; northern midlatitudes largely glaciated.

Interglacial climatic states will not initiate or support ice sheets of continental magnitude in the present temperate regions. Temperate interstadial and interstadial states will support an already established ice sheet, but will not initiate one unless some external triggering phenomena, such as particulate loading of the atmosphere by volcanic eruption, occurs. Stadial climatic states will initiate glaciation.

Climate affects regional precipitation, evapo-transpiration, infiltration, river runoff, glaciation, and hence, such things as sea level, erosion and sedimentation rates. The requirements for this submodel mainly focus on volcanic dust loading of the atmosphere and the earth's orbital parameters. On the time scale of $10^{4}-10^{5}$ years, the pattern of solar radiation reaching the earth's surface is assumed to be dominant over other natural variables driving the temporal variations in the North American climate.

\section{Milankovitch Theory}

The difference between the present average annual surface air temperatures and that consistent with the most recent glacial episode $(18,000$ years before the present) is estimated to be 5 to $6^{\circ} \mathrm{C}$ (Kukla). (a) On the time scale of $10^{0}-10^{2}$ years, climate is modified by the changes in atmospheric turbidity. Such increase was observed to cause a decrease in the insolation reaching the

(a) This information was based on work done by Kukla, which is reported in part in this document. A summary of Kukla's research has been published (Kukla 1979). 
ground and, consequently, in the air surface temperatures. Natural fluctuations of atmospheric turbidity are related to volcanic activity (which is in principle random), to the changing areas of deserts and semideserts, and to the varying vigor of atmospheric circulation. On the longer time scales $\left(10^{4}-10^{5}\right.$ years $)$, the variation in the three principle elements of the earth's orbit around the sun are considered responsible for a considerable part of natural climatic variance. Future magnitudes of surface temperatures may be estimated by combining the three conventional measures of the earth-sun orbital elements in an equation whose solution closely correlates with the available paleoclimate (historical) evidence of the last 250,000 years.

The three variables are: 1) the obliquity, or tilt of the earth's rotational axis relative to the plane of the ecliptic $(E), 2$ ) the eccentricity or the measure of the sun's departure from the geometric center of the ecliptic (e), and 3) the longitude of the perihelion or the angular distance to the point of the Earth's closest approach to the sun from the autumnal equinox (W).

The periodicities of these three variables are: $E=40,000$ years, $e=92,000$ years, and $W=21,000$ years. With the proper phase relationships, the maximums associated with the various harmonics will result in a dominant 100,000 year periodicity. The major feature of the ice ages for the last 600,000 years is this 100,000 year periodicity.

With harmonic analysis, it is possible to compute a relative Astronomic Climatic Index (ACLIN). The values of ACLIN over the last $10^{6}$ years and the projected values over the next $10^{6}$ years are shown in Figure 10 . Correspondence of ACLIN with radiometric data on coral reefs is shown in Figure 11 . The calibration of the ACLIN index with such radiometric data and with the deep sea record resulted in the following relationships:

- A full interglacial climate lasted for about 10,000 years and was centered at ACLIN peaks of 4.3. Global climates were not significantly different from present or were warmer.

- Temperate interstadial climates lasted for about 8000 years and were centered at ACLIN peaks of 3.6. Global climates were cooler than at present but generally mild. 


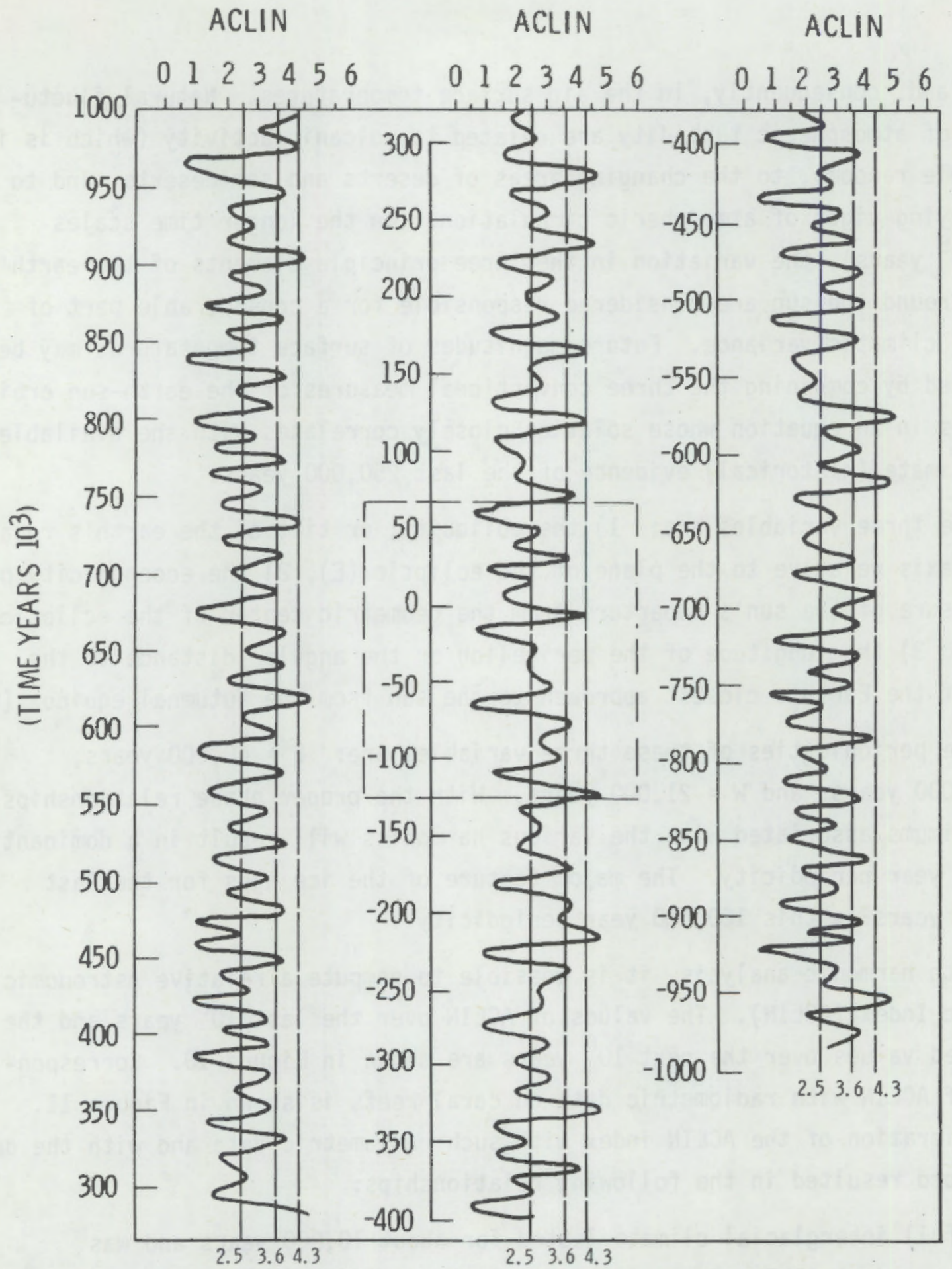

FIGURE 10. Astronomical Climatic Index (ACLIN) as a Function of Time (modified by Kukla). (a) (Outlined area detailed in Figure 11. Present time at year $=0$, past $=$ negative numbers, future $=$ positive numbers.)

(a) This figure is based on research done by Kukla, which is reported on in part in this document 


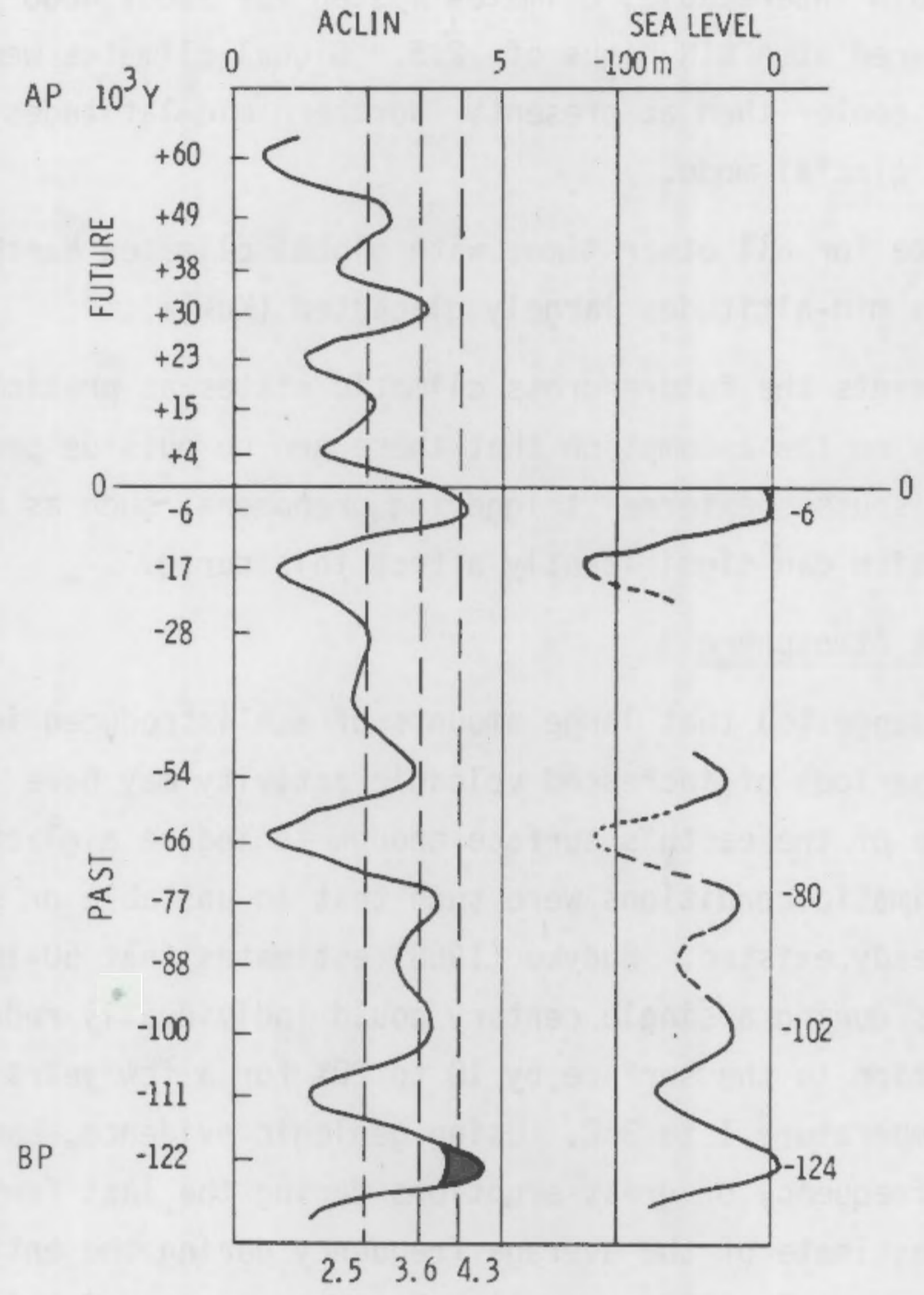

FIGURE 11. ACLIN for 122,000 B.P. (Before Present) to 60,000 A.P. (After Present). (a) (Correlated with past sea levels based on radiometrically-dated coral reefs in Barbados and New Guinea. Detailed from Figure 10.)

(a) This figure is based on research done by Kukla, which is reported on in part in this document. 
- Moderate or cold interstadial climates lasted for about 4000 years and were centered at ACLIN highs of 2.5. Global climates were significantly cooler than at present. Northern mid-latitudes are in or close to a glacial mode.

- Stadial climate for all other time, with global climates harsh and cold, northern mid-altitudes largely glaciated (Kukla). (a)

Figure 12 presents the future gross climatic states as predicted by the Milankovitch theory on the assumption that there are no outside perturbations. The next section discusses external triggering phenomena, such as major volcanic eruptions, which can significantly affect this curve.

Dust Loading of the Atmosphere

Research has suggested that large amounts of ash introduced into the atmosphere during periods of increased volcanic activity may have lowered the average temperature of the earth's surface enough to induce a glacial episode if the existing climatic conditions were such that an unstable or sensitive climatic state already existed. Budyko (1968) estimates that 50-100 great explosive eruptions during a single century could individually reduce the direct solar radiation to the surface by 10 to $20 \%$ for a few years lowering the average air temperature 1 to $3^{\circ} \mathrm{C}$. Using geologic evidence, Lamb (1970) suggests that the frequency of great eruptions during the last few centuries is a conservative estimate of the average frequency during the entire Quaternary period (about 2 million years). For the purpose of this study, it is assumed that the frequency of major volcanic eruptions during the last four or five centuries will continue for the next $10^{6}$ years. Figure 13 shows the stratospheric dust loading curve for the last 120 years.

Lamb's (1970) study of the chronology of volcanic eruptions from 1500 to 1968 reveals that 25 individual eruptions were greater than or equal to the 1883 eruption of Krakatoa. Over this time span, 50 additional eruptions occurred ranging individually in size from 10 to $80 \%$ of the level of Krakatoa. Lamb

(a) This information was based on work done by Kukla, which is reported in part in this document. A summary of Kukla's research has been published (Kuk la 1979). 


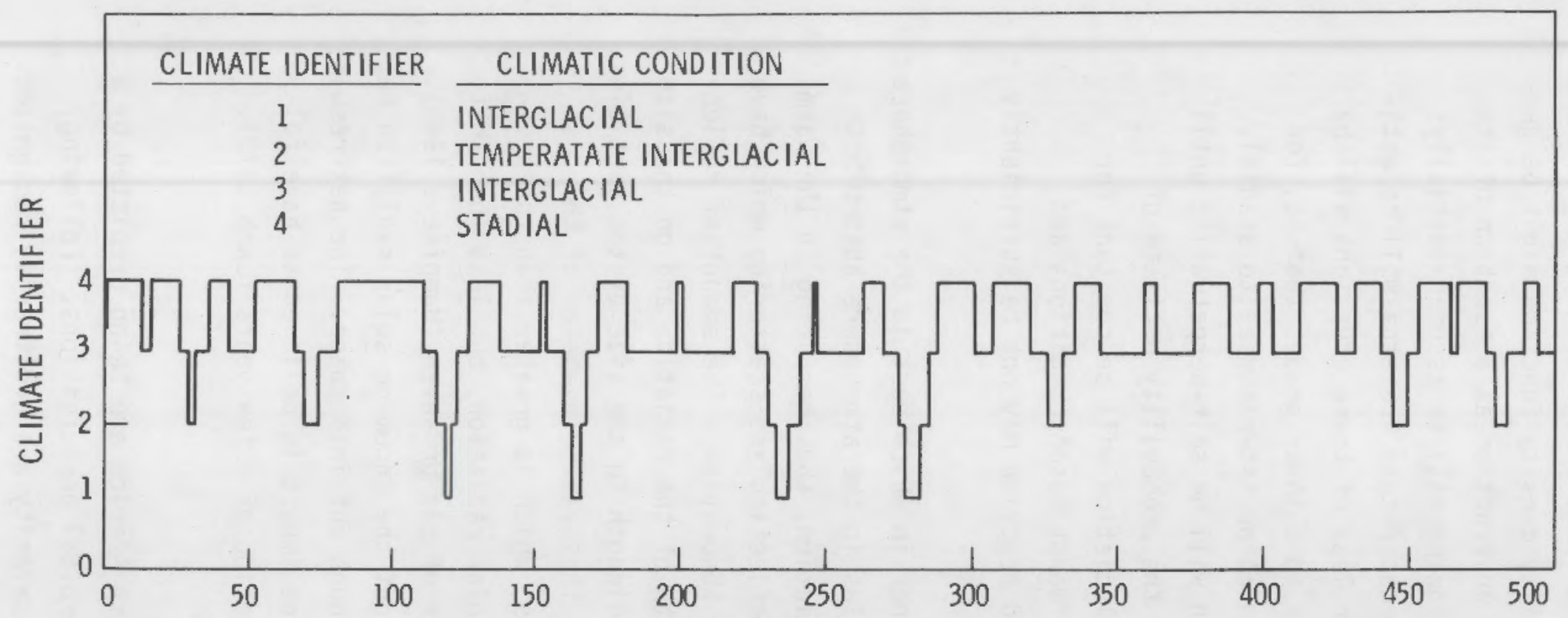

w

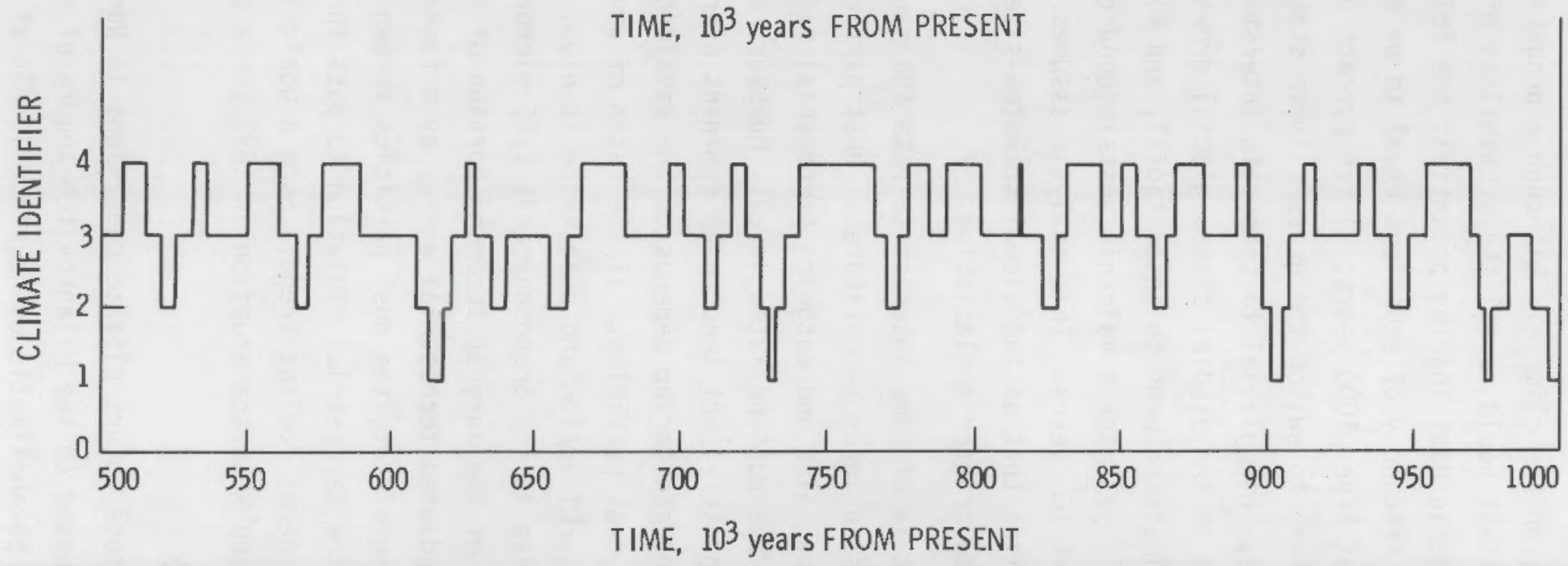

FIGURE 12. Future Natural Climate vs. Time as Predicted From ACLIN Without Ash Load Perturbations 
considers these 75 individual eruptions to be large enough to have significant effects on the climate. Although a probability density function might be generated that would reveal the probability of an eruption as a function of its atmospheric dust loading potential, the following will be assumed initially: 1) the frequency of eruptions equal to or greater than Krakatoa will be estimated at 5 per 1000 years, 2) ten percent or less of these eruptions will be sufficient to switch the gross climate state to a lower grade, that is, for example, interglacial to temperate interstadial or interstadial to stadial, 3) once in the stadial state, glacial growth will be self-perpetuating until the climate returns to interstadial, and 4 ) the probability estimate of $5 \times 10^{-3} \mathrm{yr}^{-1}$ for a volcanic dust-induced glaciation will be constant for the next $10^{6}$ years. This analysis assumes "worst case" conditions and recognizes that an individual Krakatoa-sized eruption may not be sufficiently large to trigger a glaciation.

It is of some interest to note the manner in which dust in the atmosphere results in lower temperatures. Dust particles in the atmosphere absorb both incoming solar and outgoing terrestrial radiation, thus resulting in the warming of the dust-polluted level. However, reflection and scattering which have an opposite effect tend to be dominant over absorbtion. The amount of reflection and scattering depends on the wavelength of the radiation and on the size of the dust particles. If the ratio of wavelength to the size of the particles is low, reflection and scattering is high. The average diameter of the dust particles in the troposphere is 1.85 microns, which is greater than the wavelength of the largest incoming portion of solar radiation, but less than that of reradiated terrestrial energy by a factor of six or seven (Humpfreys 1940). Thus, in effect, the dust particles screen out the incoming solar radiation but allow the terrestrial radiation to pass through out into space. The net result is a general cooling trend. Such a worldwide impact is believed to have followed the Krakatoa eruption in 1883 for a period of a few years (Lamb 1970). $\underline{\text { Summary }}$

Gross future climate conditions in North America are being predicted by a model based on the Milankovitch theory of orbital perturbations. Following common paleoclimatic usage, four levels of severity are arbitrarily recognized. 


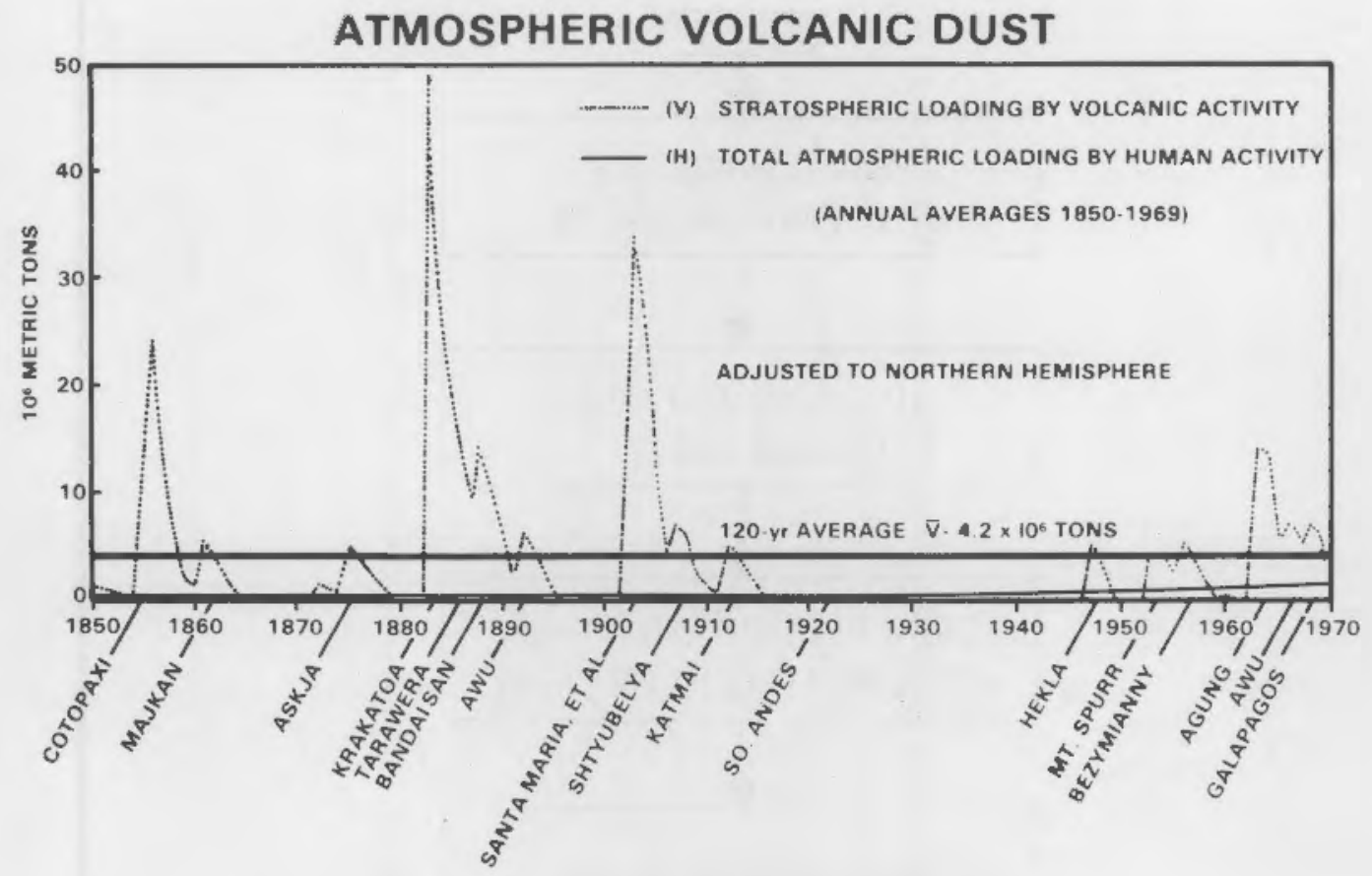

FIGURE 13. Atmospheric Dust Load (Bullard 1976)

When the orbital parameters are in transitional mode, terrestrial factors, such as exceptionally frequent volcanic eruptions and/or man-made particulate pollution, could induce a shift into the cooler climatic state and thereby initiate major alpine and/or continental glaciations. In addition to glacial activity, climate is largely the driving force for precipitation, groundwater, recharge, runoff, and sea level fluctuations. The general logic flow for the climate submodel is presented in Figure 14. Variable definitions are given in Table 8, and the input requirements and available data are presented in Table 9.

\section{PRECIPITATION, RUNOFF, AND INFILTRATION}

Precipitation, infiltration, evapotranspiration, base level flow, and surface water flow are determined to a major extent by climate, distance from large water bodies, and the general topography. Frecipitation can be shown to affect erosion, flooding and sedimentation, groundwater flows, and water table elevations. 


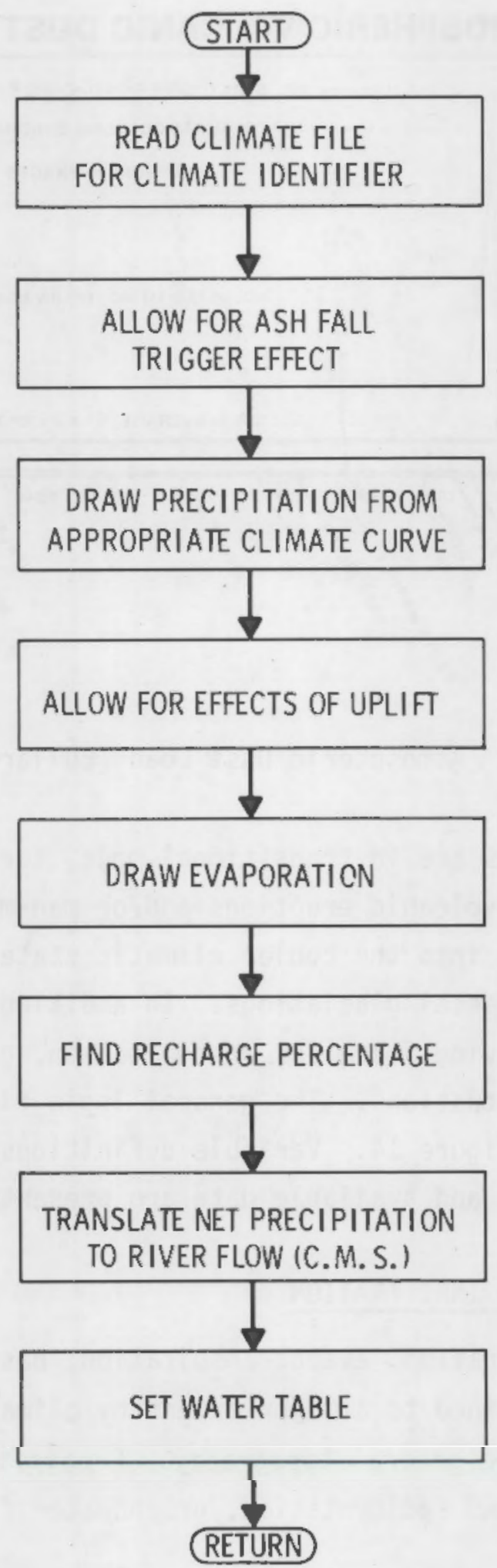

FIGURE 14. Climate, Submodel 


\section{TABLE 9. Climate Submodel Data(a)}

SUBJECT

ILLUSTRATIVE

COMMENTS

GRAPHICAL REPRESENTATION OR DATA

\begin{tabular}{|c|c|c|}
\hline $\begin{array}{l}\text { CLIMATE STATE I AS A FUNCTION } \\
\text { OF TIME }\end{array}$ & \begin{tabular}{|cc} 
CLIMATIC & 4 \\
STATE & 3 \\
& 2 \\
& 1
\end{tabular} SEE FIGURE 12 & BASED ON ORBITAL PARAMETERS \\
\hline $\begin{array}{l}\text { PROBABILITY OF RANDOM } \\
\text { PERTURBATION CHANGING } \\
\text { CLIMATIC STATE }\end{array}$ & $5 \times 10^{-3} \mathrm{YR}^{-1}$ & $\begin{array}{l}\text { PROBABILITY OF A MAJOR } \\
\text { VOLCANIC ERUPTION CAPABLE } \\
\text { OF PERTURBING THE CLIMATE }\end{array}$ \\
\hline $\begin{array}{l}\text { DENSITY CURVE GIVING FRACTION } \\
\text { OF PRECIPITATION FOR EACH } \\
\text { CLIMATIC STATE }\end{array}$ & 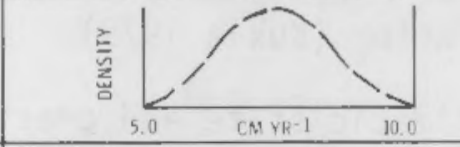 & $\mathrm{cm} \mathrm{Yr}{ }^{-1}$ \\
\hline $\begin{array}{l}\text { DENSITY CURVE GIVING FRACTION } \\
\text { OF PRECIPITATION RETURNED BY } \\
\text { EVAPORATION FOR EACH CLIMATE } \\
\text { STATE } ~\end{array}$ & 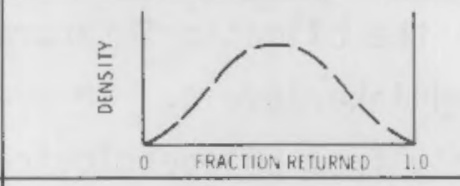 & \\
\hline $\begin{array}{l}\text { PERCENTAGE OF RAIN FALL GOING } \\
\text { TO RECHARGE FOR EACH THE } \\
\text { CLIMATIC STATE }\end{array}$ & & \\
\hline $\begin{array}{l}\text { FACTOR TO CHANGE PRECIPITATION } \\
\text { TO RIVER FLOW } \mathrm{M}^{3} \mathrm{~S}^{-1}\end{array}$ & & \\
\hline CHANCE FOR UPLIFT TO WEST & & \\
\hline CHANCE FOR LOCAL UPLIFT & & \\
\hline CHANCE FOR UPLIFT TO EAST & & \\
\hline $\begin{array}{l}\text { FACTOR USED TO CHANGE } \\
\text { PRECIPITATION DUE TO UPLIFT } \\
\text { INEAST }\end{array}$ & & \\
\hline $\begin{array}{l}\text { FACTOR USED TO CHANGE } \\
\text { PRECIPITATION DUE TO UPLIFT } \\
\text { IN WEST }\end{array}$ & & \\
\hline $\begin{array}{l}\text { FACTOR USED TO CHANGE } \\
\text { PRECIPITATION DUE TO LOCAL } \\
\text { UPLIFT }\end{array}$ & & \\
\hline
\end{tabular}

1) INTERGLACIAL, 2) TEMPERATE STADIAL, 3) INTERSTADIAL, 4) STADIAL

(a) Data is under development and not available at this time. 
Precipitation

The probability of the average annual precipitation, I, changing by a factor over its present level is defined as:

$$
I=F\left(c, d_{m}, r\right)
$$

where $I$ is a function of:

$c=$ climatic state

$d_{m}=$ downwind distance from a large body of water

$r=$ regional topographic factor (Kukla 1979).

The relationship between climatic state and precipitation was obtained from published data dealing with the climatic interpretations of Pleistocene (past 1 million yr) snowlines and lake levels. In addition, past precipitation has been estimated indirectly from paleoecological vegetation analyses based on the pollen record. The reconstructed departures of pleistocene annual temperature and precipitation from present local equivalents are presented in Table 10 and Figure 15. From these data, curves can be generated relating precipitation levels to the Astronomic Climate Index (ACLIN). However, as shown in Figure 16 these curves, which were generated with test data, are valid only for fixed $d_{m}$ and $r$ factors. It may be possible to estimate the incremental. precipitation that might be expected either by decreasing the distance to a large water body or changing the topographic factor.

Kukla's data ${ }^{(a)}$ show that the estimated difference between the present and the full glacial precipitation is, generally, within the ranges of recent year-to-year variability as recorded in the western United States during the last 90 years. Thus, he concludes that even the expected extremes do not significantly differ from the recently observed short term variations. In other words, if the topography and distance to large water bodies remain relatively constant, the available precipitation data indicate that a two- to fourfold increase in precipitation should be considered conservative.

(a) This information was based on work done by Kukla, which is reported in part in this document. A summary of Kukla's research has been published (Kukla 1979). 
TABLE 10. Late Pleistocene Climate Reconstructions Overview of Published Data

\begin{tabular}{|c|c|c|c|c|c|c|c|c|c|}
\hline \multirow[b]{2}{*}{ Site } & \multirow[b]{2}{*}{$\begin{array}{c}\text { Author \& } \\
\text { Reference }\end{array}$} & \multicolumn{2}{|c|}{$\begin{array}{c}\text { Present } \\
\text { Annual Mean }\end{array}$} & \multirow[b]{2}{*}{$\begin{array}{l}\text { Precip } \\
(\mathrm{mm}) \\
\end{array}$} & \multicolumn{3}{|c|}{ Reconstructed } & \multicolumn{2}{|c|}{ Difference } \\
\hline & & $\begin{array}{l}\text { Precip } \\
(\mathrm{mm})\end{array}$ & $\begin{array}{l}\text { Temp } \\
\text { (C) }\end{array}$ & & $\begin{array}{l}\text { Temp } \\
\text { (C) }\end{array}$ & $\begin{array}{l}\text { Evap } \\
\text { (mm) }\end{array}$ & $\begin{array}{c}\text { Runoff } \\
(\mathrm{mm}) \\
\end{array}$ & $\begin{array}{l}\text { Precip } \\
(\mathrm{mm}) \\
\end{array}$ & $\begin{array}{l}\text { Temp } \\
\text { (C) }\end{array}$ \\
\hline Lake Lahontan & $\begin{array}{c}\text { Broecker et al. } \\
(21)\end{array}$ & 200 & & 460 & & 960 & & +260 & -5 \\
\hline Lake Lahontan & Galloway (rt) & 180 & & 160 & & & & -20 & $-(10-11)$ \\
\hline Lake Lahontan & Mifflin et al. & 155 & & $280^{a}$ & & $940^{a}$ & 170 & $+125^{a}$ & -2.75 \\
\hline Lake Lahontan & Benson (re) & 155 & & $185-$ & & $150-$ & & $+(30-230)$ & $-(10-15)$ \\
\hline Extreme N.W. Nev. & Mifflin et al. & 295 & & 535 & & & & +240 & -2.75 \\
\hline Lake Bonneville & Galloway (rt) & 200 & & 185 & & & & -15 & $-(10-11)$ \\
\hline $\begin{array}{l}\text { Spring Valley } \\
\text { Lake, Nev. }\end{array}$ & $\begin{array}{c}\text { Snyder et al. } \\
\text { (te) }\end{array}$ & 300 & & 510 & & 790 & & +210 & $-(4.5-5)$ \\
\hline $\begin{array}{l}\text { Spring Valley } \\
\text { Lake, Nev. }\end{array}$ & Galloway (rt) & 230 & & 185 & & & & -45 & $-(10-11)$ \\
\hline $\begin{array}{l}\text { Spring Valley } \\
\text { Lake, Nev. }\end{array}$ & Mifflin et al & 150 & & $\begin{array}{l}370^{a} \\
425^{b}\end{array}$ & & $-13 \%$ & & $\begin{array}{l}+220^{a} \\
+275^{b}\end{array}$ & \\
\hline Basin, Nev. & $\begin{array}{c}\text { Mifflin et al. } \\
(47)\end{array}$ & 200 & & 370 & & $10 \%$ & & +170 & -2.75 \\
\hline & Leopold (10) & 360 & & 510 & & 740 & 125 & +150 & $-(6-7)$ \\
\hline & Galloway (45) & 320 & & 275 & & 620 & & -45 & $-(10-11)$ \\
\hline
\end{tabular}


TABLE 10. (contd)

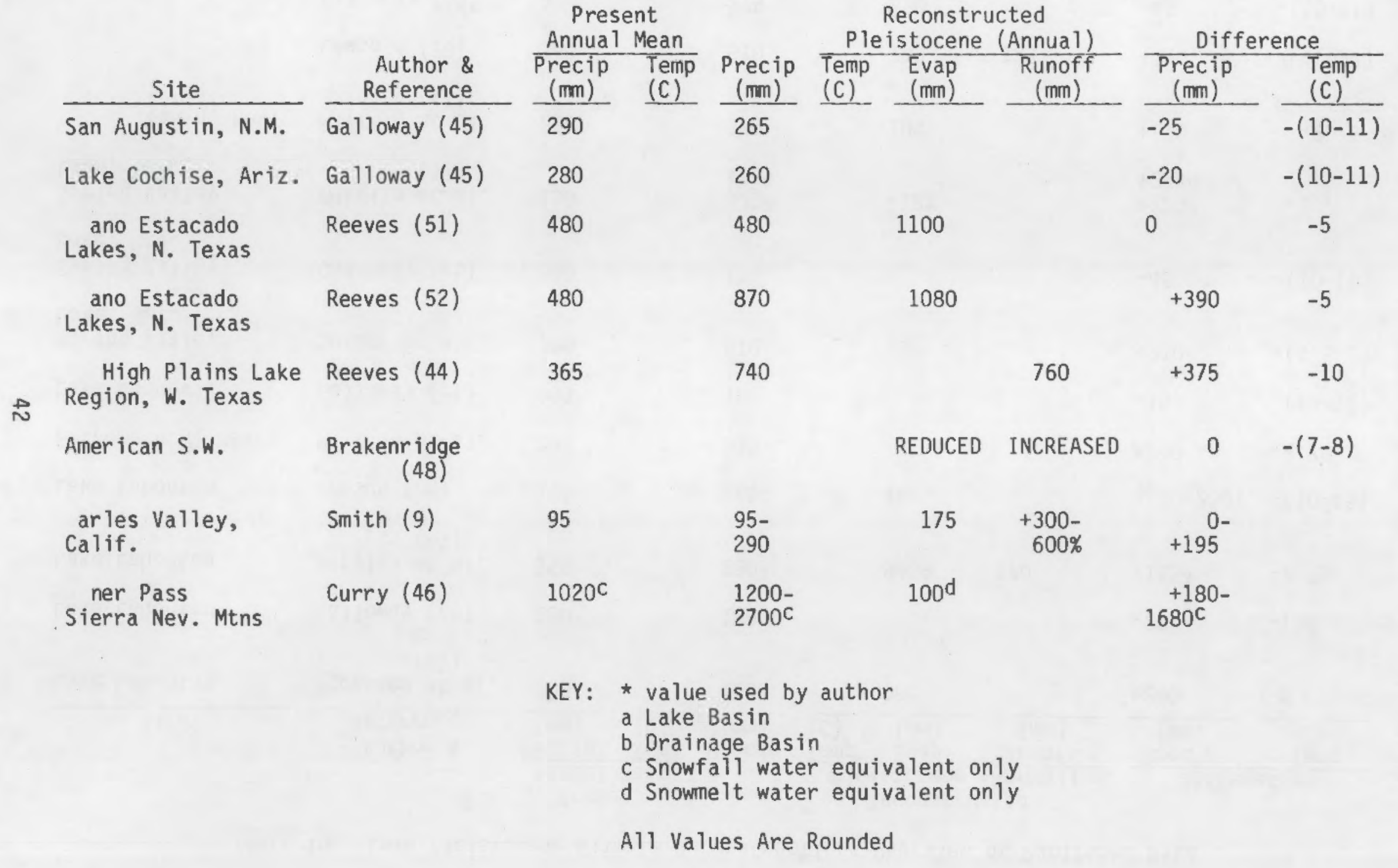




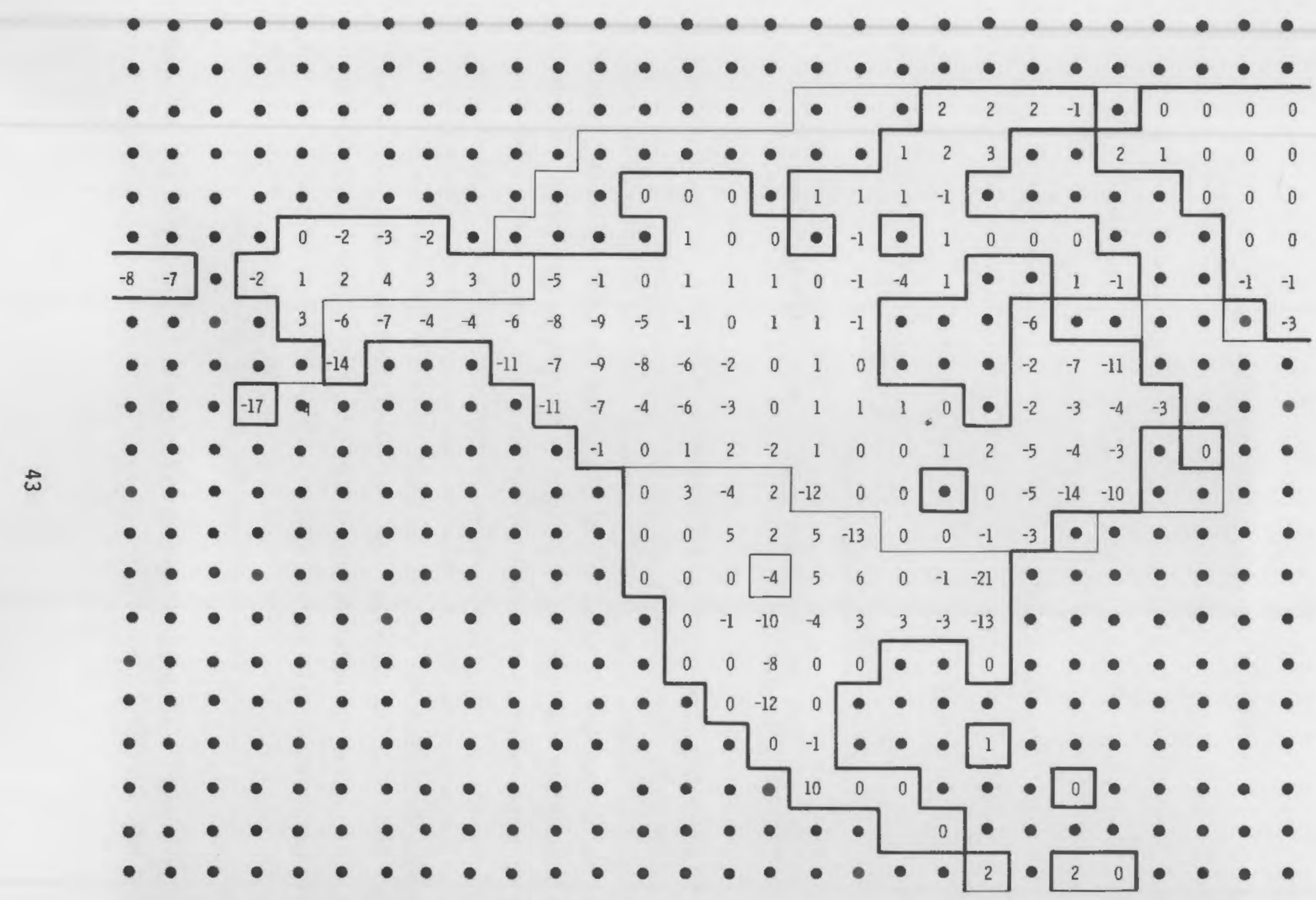

FIGURE 15. Calculation of Difference of Surmer Precipitation in mm. Day-1 Between 18,000 Years BP to Present Day, by Members of CLIMAP Group. (map of North America supplied by T. Hughes) 


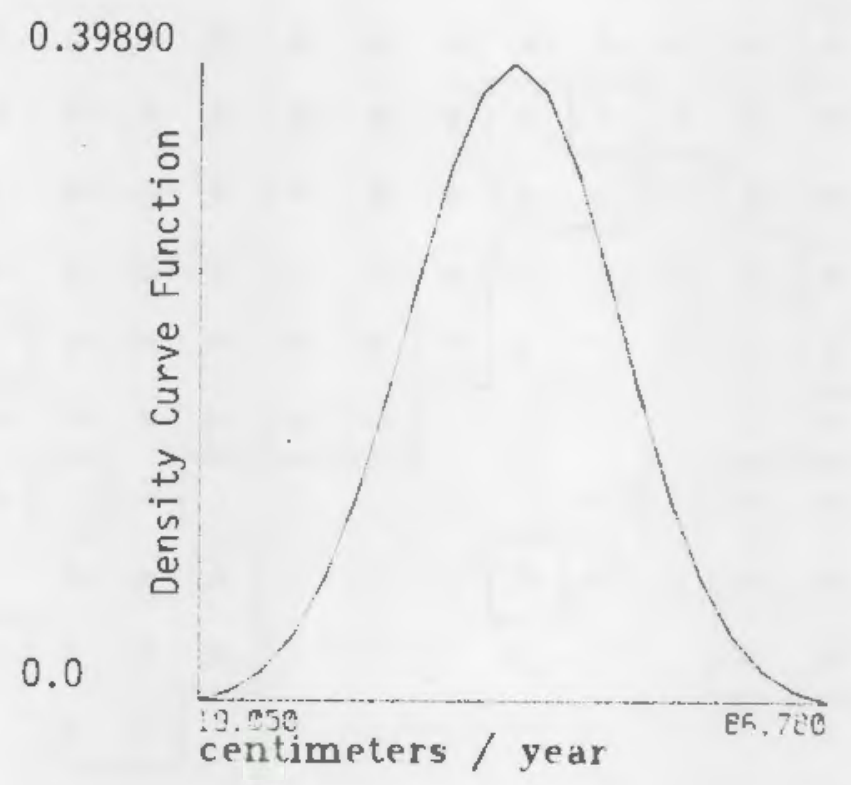

FIGURE 16. Test Density Curves Relating Precipitation to the Climatic Index

Unfortunately, the validity of the reconstructed data is limited and the possibility of larger increments can not be totally dismissed. For example, in his discussion on glaciation, Bu11 ${ }^{(a)}$ concludes that the ablation or melting of ice during the retreat phase of the Laurentide ice sheet apparently cannot alone account for the inferred flow rates in the Mississippi River. Ice sheet ablation might result in an annual river flow on the order of ten times the present volume, but measurements on the changes in the stable oxygen isotope ratio of cores from the Gulf of Mexico allude to substantially higher river discharges to account for the four to eight percent dilution of the Gulf waters. Bull asks the question: Was the rainfall in the drainage basin much greater during the ice ablation period than now, even though it appears the climate was drier during the full stadial climate periods? Paleoclimatic evidence indicates that this indeed might have been the case in the Midwest. For example, spruce forests flourished over the Nebraskan sand dunes during

(a) Bull's work is reported in part in this report. A summary of his research has been published (Bull 1979). 
deglaciation times. The area was arid during full glacials and is also arid today. A similar situation may have occurred in the Columbia Plateau. Regardless of the uncertainty, until more evidence can be gathered on paleodrainage systems, precipitation, and runoff, the two- to four-fold increase in precipitation will be assumed for the areas draining the area of the Columbia Plateau.

Before expending additional effort characterizing probability density curves for precipitation, it is prudent to consider how a four-fold or even a ten-fold increase in precipitation might affect the aquifers and surface drainage systems in the vicinity of the repository. Qualitative relationships between rainfall and recharge, and recharge and hydraulic gradients are shown in Figure 17. The percentage of the precipitation occurring as base flow (groundwater) and that occurring as surface runoff must be estimated. To lend perspective, the average annual recorded Columbia River flow just north of Hanford is $3.43 \times 10^{3} \mathrm{~m}^{3} \mathrm{~s}^{-1}$ with maximum possible flows of $3.96 \times 10^{4} \mathrm{~m}^{3} \mathrm{~s}^{-1}$ (Corps of Engineers 1950). If precipitation increased by a factor of four with no change in runoff ratio, then the average flow might be about $1.36 \times 10^{4}$ $\mathrm{m}^{3} \mathrm{~s}^{-1}$. Results of hydrograph examinations indicate that the mean annual flow ranges from 25 to $40 \%$ of the peak flow (Leopold, et al. 1964). Thus for a four fold increase in precipitation, a peak flow of $\left(1.36 \times 10^{4} / 0.25\right)$ or $5.66 \times$ $10^{4} \mathrm{~m}^{3} \mathrm{~s}^{-1}$ might be possible for the Columbia River. This estimate is independent of glacial activity and does not take account of changes in factors such as evapotranspiration, or ground water recharge rates. Additionally, during stadial conditions river flow and ground water recharge may be limited to three months a year with consequent increases in flow during peak conditions. The potential consequences associated with such a flow are discussed in the section on flooding, erosion, and sedimentation.

Obviously such factors as surface retention, vegetation cover, evapotranspiration, and infiltration capacity of the soil are important with respect to high resolution studies and real world conditions, but for this generic study the following assumptions are made:

1) increased precipitation will not increase deep aquifer flow conditions in the vicinity of the site to any significant degree, unless the water is under pressure caused by the formation of a lake or glacial ice over a large portion of the recharge area 


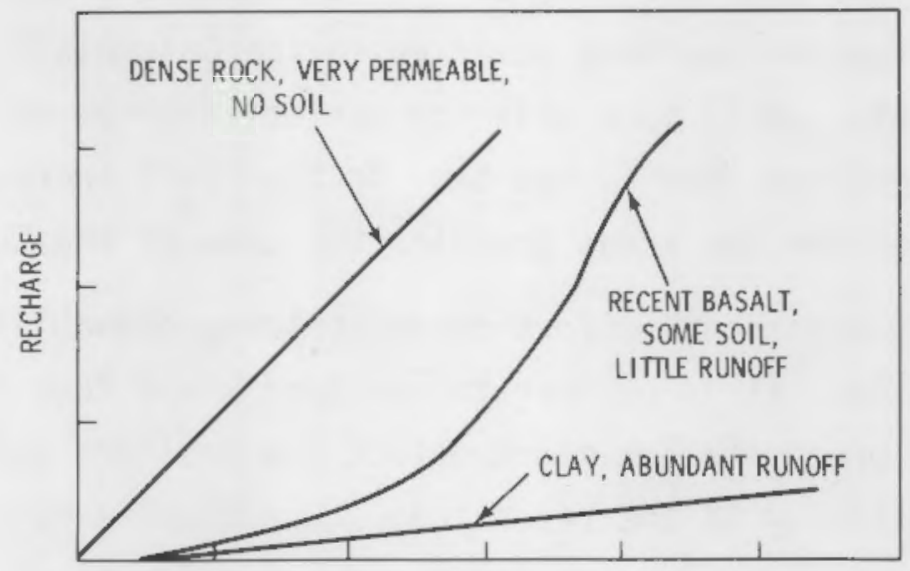

RAINFALL

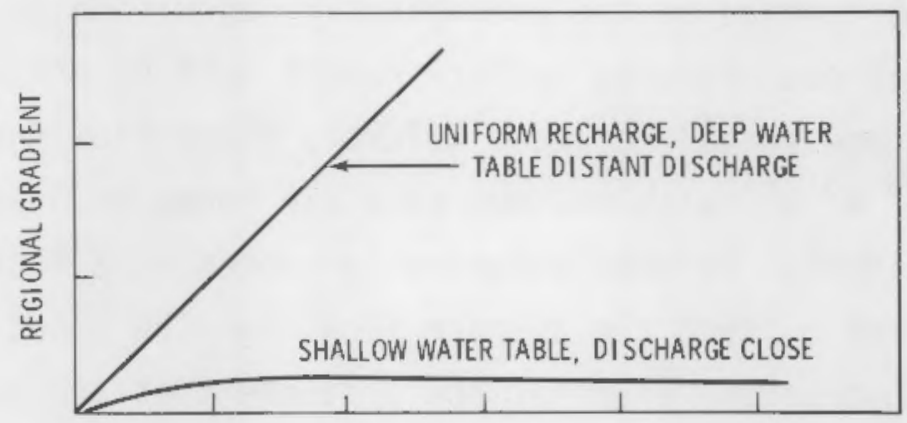

RECHARGE

FIGURE 17. Possible Relationships Among Rainfa11, Recharge, and Regional Hydraulic Gradients (Davis 1979)

2) nearly all precipitation ( $80 \%$ will be available for surface flow and associated river erosion, flooding, and sedimentation effects. The assumptions are based on the evaluation of paleoclimatic indicators from the Columbia Plateau.

There is no evidence of a significantly denser vegetational cover in the area during Late Pleistocene. On the contrary: migrating loess and sand dunes point to a rather bare surface. In such conditions the extra precipitation has to come either as torrential rains during the growing season or as snow or rain during winter. In both cases the surface permeability had to be low: in summer the soil was dry and in winter frozen. It is probable that an 
impermeable permanently frozen ground (permafrost) existed during peak stadials over much of the Columbia Plateau. (a)

Summary

Existing data indicate a two to four fold maximum increase in precipitation for the area in question. Eighty percent of this water will be assumed to augment surface drainage systems. Recharge to the unconfined aquifer at the site will be increased by a factor of three to five or more since evapotranspiration rates will be subdued during the cooler, wetter climate. This may affect the water table elevation but should have no significant effect on a hydraulically isolated 300-1000 m deep repository. The deeper aquifer will be unaffected by an increase in precipitation unless a lake or ice sheet is superimposed over the major part of a recharge area. The model will vary the precipitation in response to temporal changes in the Astronomic $\mathrm{Climatic}$ Index (ACLIN), major topographic changes, and changes in the distance to the ocean. Maximum increases in precipitation will increase the volumetric flow in the Columbia to approximately $1.42 \times 10^{4} \mathrm{~m}^{3} \mathrm{~s}^{-1}$. Peak flows of short duration, however, will be assumed to reach $5.6610^{4} \mathrm{~m}^{3} \mathrm{~s}^{-1}$. Precipitation, runoff, and infiltration are a part of the climate submodel shown in Figure 15. Table 11 summarizes input requirements and current data availability.

There is the possibility that future climatic conditions may cause the onset of renewed worldwide continental and/or alpine glaciation. It is therefore necessary to anticipate the consequences of such events. These consequences are addressed in the continental and alpine glaciation submodels.

\section{CONTINENTAL GLACIATION}

Analysis of the effects of continental glaciation in the Columbia Plateau region is somewhat complicated, largely because there is no direct evidence supporting the existence of an ice sheet ever covering the plateau. Some observations of the climatic history of the last million years indicate that for only about $10 \%$ of the time was the climate as warm or warmer than the

(a) This information was based on work done by Kukla, which is reported in part in this document. A summary of Kukla's research has been published (Kukla 1979). 
TABLE 11. Age of Glacial Terminations - Summary of Published Estimates(a)

\begin{tabular}{|c|c|c|c|c|c|c|c|c|}
\hline $\begin{array}{c}\text { Tertaina- } \\
\text { tion }\end{array}$ & $\begin{array}{c}\text { Droocker } \\
\text { and Van Donk } \\
1970\end{array}$ & $\begin{array}{r}\text { Kukla } \\
1970\end{array}$ & $\begin{array}{c}\text { Shackleton } \\
\text { and Opdyke } \\
1973\end{array}$ & $\begin{array}{r}\text { Kukla } \\
1975\end{array}$ & $\begin{array}{l}\text { Ruddiman } \\
\text { and McIntyre. } \\
1976\end{array}$ & $\begin{array}{c}\text { Hays, } \\
\text { Imbric and } \\
\text { Shackleton } \\
1976\end{array}$ & \multicolumn{2}{|c|}{$\begin{array}{c}\text { Avernge } \\
\left(10^{3}\right)\end{array}$} \\
\hline$I$ & 11,000 & 10,500 & 13,000 & 11,000 & 13,500 & 10,000 & $11.5+$ & $\begin{array}{l}-1 \\
+2\end{array}$ \\
\hline II & 227,000 & 128,000 & 128,000 & 128,000 & 127,000 & 127,000 & 228.0 & $\begin{array}{l}-1 \\
+0\end{array}$ \\
\hline III & 225,000 & 213,000 & 251,000 & 245,000 & 220,000 & 247,000 & 240.0 & $\begin{array}{l}-20 \\
+10\end{array}$ \\
\hline IV & 300,000 & 333,000 & 347,000 & 335,000 & 315,000 & 336,000 & 330.0 . & $\begin{array}{l}-30 \\
+20\end{array}$ \\
\hline v & 380,000 & 370,000 & 440,000 & 415,000 & 380,000 & 425,000 & 400.0 & $\begin{array}{l}-30 \\
+40\end{array}$ \\
\hline vI & & 485,000 & 502,000 & 480,000 & 455,000 & & 480.0 & $\begin{array}{l}-25 \\
+20\end{array}$ \\
\hline VII & & 600,000 & 592,000 & 575,000 & 515,000 & & 570.0 & $\begin{array}{l}-55 \\
+30\end{array}$ \\
\hline VIII & & & 617,000 & 035,000 & 605,000 & & 630.0 & $\begin{array}{l}-25 \\
+20\end{array}$ \\
\hline$I x$ & & $72 G, 000$ & 706,000 & 700,000 & & & 710.0 & $\begin{array}{l}-10 \\
+15\end{array}$ \\
\hline$x$ & & 845,000 & 782,000 & & & & 810.0 & $\begin{array}{l}-30 \\
+35\end{array}$ \\
\hline
\end{tabular}

(a) This information was compiled by Kukla, and reported in this document. 
present. Also, the past record shows that no interval of global climate with temperatures as warm or warmer than present lasted uninterruptedly for more than about $1.1 \times 10^{4}$ years. Paleoclimatic studies suggest that up to ten full glacial cycles might be expected in the next $10^{6}$ years.

The separation between the repository site and the edge of an ice sheet at its maximum extent is an important variable. Past advances will be used to estimate future advances, with the one important exception discussed below. Similarly, the separation between the major aquifer recharge areas and the ice sheets must be estimated. If the ice should overrun the repository site and/or the recharge areas, pressurized vertical recharge to unconfined and/or confined systems should be assumed. The anomalous pressure will depend on the estimated ice thickness. If the ice sheet comes within approximately $200 \mathrm{~km}$ of the site, flexural stresses at and beyond the edge of the ice should be estimated. The current computer code relies on a straightforward mechanical loading model. The probability of fracturing and/or shearing of pre-existing joints beyond the immediate edge of a sheet is calculated as a function of the computed radial and tangential flexural stresses. If fracturing is assumed, fracture spacing, length, and depth are selected from supplied probability density distributions. Associated permeability increases are computed based on an idealistic parallel plate model, described later in a section on deformation.

The rate and amount of ice scouring is selected from a similar distribution. Subsidence will depend primarily on the ice thickness, since it will be assumed that the mantle will isostatically accommodate adjustments immediately and completely. Potential major river flows will be estimated based on ice sheet ablation rates, ice dam failure frequency and magnitudes, and normal flow as determined by the climate submodel. These values will in turn input into the geomorphic events submodel. The following paragraphs elaborate on many of the components of the continental glaciation submodel.

Ice Sheet Advancement and/or Accumulation Rates

The climate model specifies several glacial episodes occurring at frequencies similar to those shown in Table 11. However, the delay or lag time between the onset of continental ice accumulation in Canada and the possible 
arrival or buildup of ice at or near the Columbia Plateau must still be estimated. The time history of ice accumulation in any given area is a complicated function of glacial velocity and net snow accumulation along the length of the glacier.

With respect to vertical accumulation of ice an estimated rate of $0.6 \mathrm{~m} \mathrm{yr}^{-1}$ seems to be the upper limit (Weertman 1964, 1976). However, he concludes that this is somewhat high, especially near the outer margins of the ice sheet. He suggests that the vertical accumulation rate ranges from 0.03 to $0.6 \mathrm{~m} \mathrm{yr}^{-1}$, once a permanent base has been established.

Very little information is available on ice advancement and retreat . In general, advancement rates are considered to be slower than recession rates. Some estimates on ablation of ice during the retreat phase of the Laurentide ice sheet are available. The southern limit of the large Erie Lobe was estimated to retreat across Ohio from its southernmost extent near Chillicothe to the position of Lake Erie, a distance of about $450 \mathrm{~km}$, in about $3 \times 10^{3}$ years. This involves a recession rate of $0.15 \mathrm{~km} \mathrm{yr}^{-1}$ (Goldthwait et al. 1965). An estimate for the later stages of ablation is $0.24 \mathrm{~km} \mathrm{yr}^{-1}$ (Brotchie and

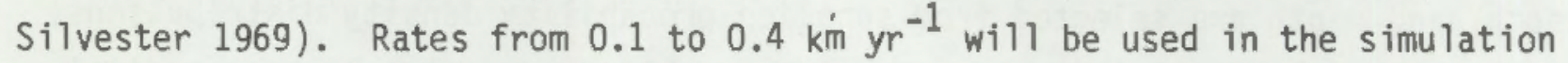
model for the retreat phase. Average advancement rates are likely to be considerably lower, but to be conservative, the similar rates will be used. Maximum Southerly Extent of Continental Ice Sheets

The maximum volume and hence extent of continental glaciations may be approximately determined from sea-core records of oxygen isotope records, which may be interpreted in terms of ice volumes. The ice-volume record over the last $6 \times 10^{5}$ years shows a general trend towards increased extent of continental ice sheets with time (Shackelton and Opdyke 1964). Thus the argument can be made that future glacial advances may extend beyond the southern border defined by the Kansan advance, which is generally considered to be the maximum Pleistocene advance. The extent of this advance is shown in Figure 18.

The team of consulting glaciologists for WISAP suggests that areas likely to be affected by ice sheets in the future are the same areas that have been glaciated in the past. However, they state that there is a possibility of an 


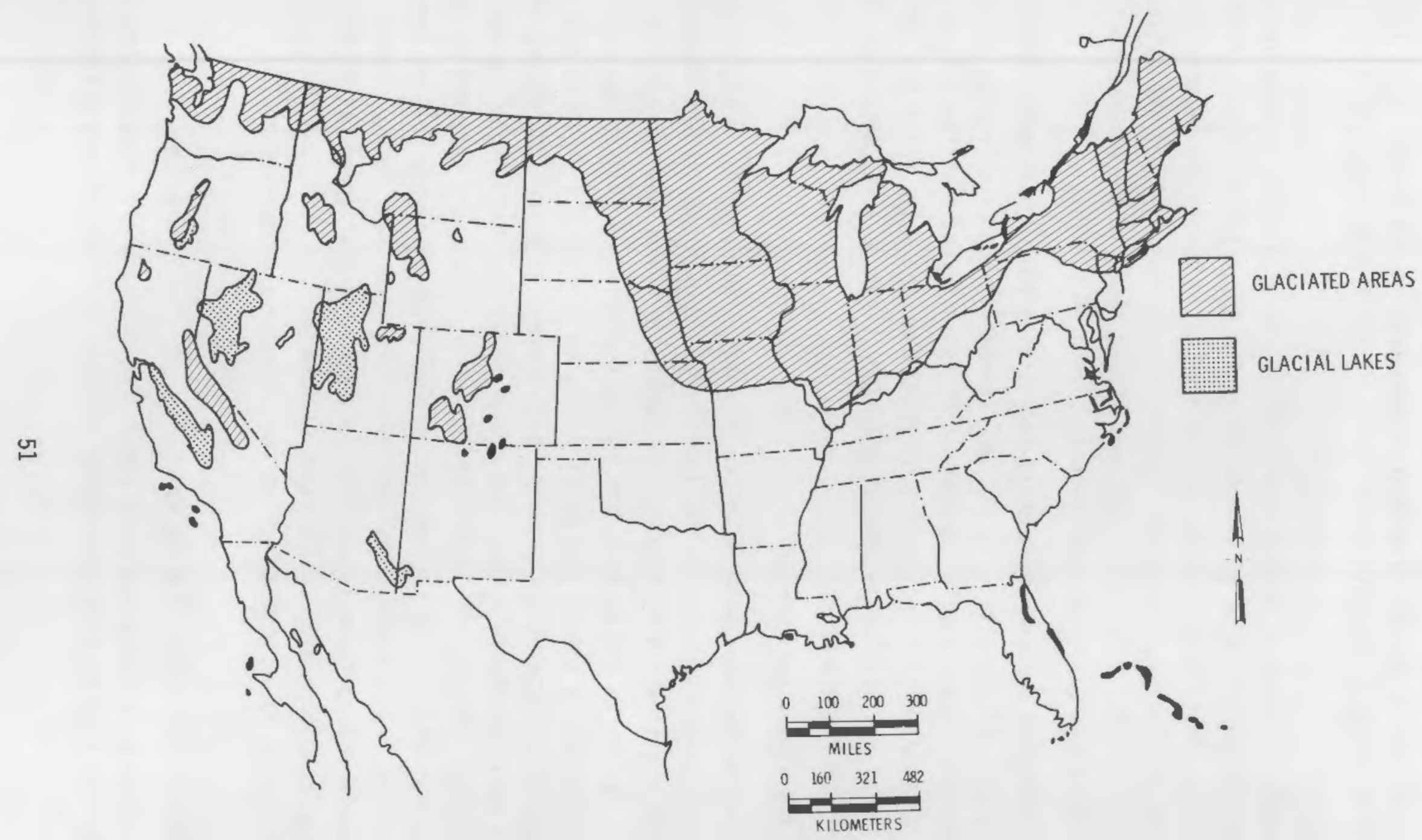

FIGURE 18. Glaciated Areas of the Coterminous United States (After U.S. Geological Survey) 
additional 400-600 km southerly advance beyond that of the Kansan stage in areas where glaciation was not predominantly controlled by topographic features.

The above estimate of an additional $400-600 \mathrm{~km}$ of glacial advance is based on the present understanding of glaciation in the midcontinent region of the United States. There may, however, be differences in glaciation between the midcontinent and Pacific Northwest. Because of this possibility, the estimate should be viewed with a degree of caution. Also, there is no evidence to indicate that the Pasco Basin has ever been glaciated in the Past.

The increasing severity hypothesis (additional 400-600 kilometer advance) discussed previously results in a $10^{-7} \mathrm{yr}^{-1}$ probability of ice loading in the Basin during any future glacial episodes. It is estimated that there is a $10^{-7} \mathrm{yr}^{-1}$ probability for ice loading directly over the site, and a $10^{-5} \mathrm{yr}^{-1}$ probability for ice loading on some of the major recharge areas servicing the aquifers of the Pasco Basin.

\section{Isostatic Subsidence and Rebound}

As a region becomes loaded with ice, isostatic adjustments in the upper mantle result in a subsidence of the land surface. When the Toad is removed, rebound occurs similar to that being experienced in Canada and Scandinavia today. For an ice to mantle rock density ratio of 1:4, an ellipsoidal ice sheet profile $(4.5 \mathrm{~km}$ thick, $1500 \mathrm{~km}$ radius), and a viscous flow model for mantle materials, computations indicate that between 1000 and 1500 meters of subsidence would be possible under the center of an ice sheet (Brotchie and Silvester 1969). However, crustal subsidence and rebound are expected to have no significant effect on subsurface permeabilities, even though shallow surficial cracking (10-15 $\mathrm{m}$ deep) may develop. This is because more pressure effects should result in an essentially constant effective stress at depth. Even isostatic rebound with uplift rates of $2 \mathrm{~cm} \mathrm{yr} \mathrm{yr}^{-1}$ in some case (Walcott 1972) should have no serious effect on the sursurface geohydrological properties.

\section{Induced Stress and Crustal Fracturing}

Some concern is being expressed concerning the flexural stresses induced just beyond the edge of large ice sheets in areas that are not being depressed 
but may be experiencing minor uplift (bulging). Table 12 and Figure 19 illustrate the deflections and stresses in the crust associated with an ice sheet of parabolic profile, of central thickness 3,000 meters and radius of $1450 \mathrm{kilo-}$ meters. The variation of the radial flexural stresses, the tangential flexural stresses, and the shear stresses are given as a function of distance from the center of the ice sheet. Of particular interest is the transition from compressive to tensional stresses and then back again to compressive stresses as one moves out radially from the periphery of the ice sheet.

The radial stresses, on the order of 10 bars, may be sufficient to fracture crustal material, especially if pre-existing zones of weakness, e.g., joints, fissures, and faults are present. Peltier and Andrews (1976) and Weertman (1976) conclude in similar studies that the induced stresses may be in the range of 10-250 bars, and fracturing, if it occurred, would be most intense near the periphery of the ice. Weertman suggests that fracturing might be the result of creep rupture instead of brittle failure. Displacement on faults along the coast of Maine, the Finger Lakes in New York, and areas associated with the Great Lakes are cited as examples of this phenomenon. Preferential erosion might occur subsequent to such fracturing. No such ice induced fracturing has been reported in the Columbia Plateau region. The possibility and effects of ice-induced fracturing are currently being investigated by a WISAP consultant.

TABLE 12. Crustal Stresses Associated with Large Ice Sheets (Bu11 1978) Distance from center, $\mathrm{km}$ $\begin{array}{llllllllll}0 & 290 & 580 & 870 & 1160 & 1450 & 1500 & 1600 & 1700 & 1800\end{array}$ $\begin{array}{llllllllllll}\text { Deflection }(m) & 802 & 769 & 673 & 513 & 288 & 23 & 4 & 4 & -1 & 0\end{array}$ Flexural stress, $\begin{array}{lllllllllll}\text { radial }(\mathrm{MPa}) & -1.6 & -1.5 & -1.5 & -1.4 & -1.1 & 10.3 & 7.9 & 1.2 & -0.4 & -0.2\end{array}$ Flexural stress, $\begin{array}{lllllllllll}\text { tangential (MPa) } & -1.6 & -1.5 & -1.5 & -1.5 & -1.6 & -1.5 & 1.3 & 0.3 & -0.1 & -0.1\end{array}$ $\begin{array}{lllllllllll}\text { Shear stress (MPa) } & 0.0 & 0.0 & 0.0 & 0.0 & 0.0 & 0.1 & -0.7 & -0.4 & -0.0 & -0.0\end{array}$ 


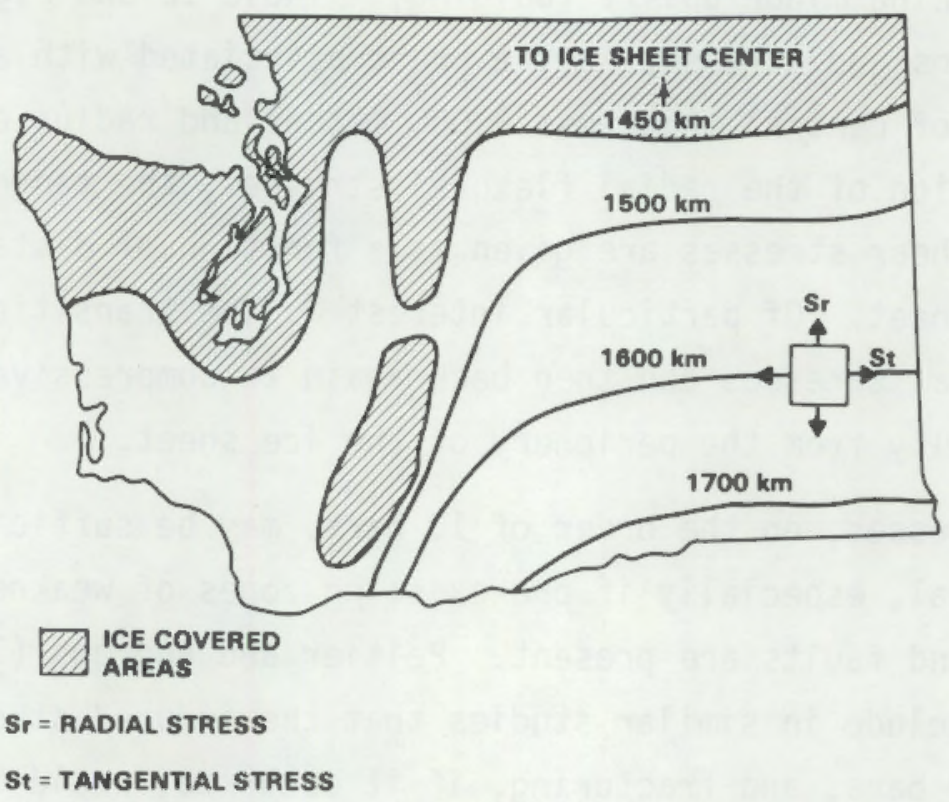

FIGURE 19. Exampie of Stress Conditions Beyond the Edge of an Ice Sheet

The radial stresses, on the order of 10 bars, may be sufficient to fracture crustal material, especially if pre-existing zones of weakness, eg, joints, fissures, and faults are present. Peltier and Andrews (1976) and Weertman (1976) conclude in similar studies that the induced stresses may be in the range of 10-250 bars, and fracturing, if it occurred, would be most intense near the periphery of the ice. Weertman suggests that fracturing might be the result of creep rupture instead of brittle failure. Displacement on faults along the coast of Maine, the Finger Lakes in New York, and areas associated with the Great Lakes are cited as examples of this phenomenon. Preferential erosion might occur subsequent to such fracturing. No such ice induced fracturing has been reported in the Columbia Plateau region. The possibility and effects of ice-induced fracturing are currently being investigated by a WISAP consultant.

The region considered susceptible to fracturing is within $200 \mathrm{~km}$ of the edge of any large ice sheet. This zone appears to be relatively independent of the ice sheet radius. The prior geologic setting is of paramount importance. In the Columbia Plateau area, the perceived lack of such features must 
carry considerable weight. However, the possibility of the ice advancing further in the future than in the past cannot be dismissed. In addition, stress relaxation may be manifested as small scale shear deformation on zones, of weakness (eg, joints) rather than as massive fractures. Incremental Permeability Associated with Ice Induced Fracturing

The research team has not made an estimate of associated fracture permeabilities. This is a very important variable and will require careful consideration. A discussion of general fracture permeability is given in a subsequent section on deformation.

Ice Scouring

A large number of ice scouring rate estimates are available in the literature (White 1972, Matthews 1975, Ruddiman 1977). The estimates span the range of 5 to $150 \mathrm{~m}$ per million years. The WISAP consulting team suggests a generic range of 30 to $300 \mathrm{~m}$ per million years during glacial stadials, although the higher end of the scale may be more pertinent to regolith (brecciated, weathered) material than to bedrock.

Sugden (1976) concludes that deep selective linear erosion can occur near the ice sheet margin by ice streams where the ice base is locally thawed and suggests that the Finger Lakes were formed in this manner. It should be noted that ice scouring occurs mainly during the advancement stage of glacial activity. During recession, the zone around the periphery of the ice should be depositional in nature although erosion, which is largely related to basal ice velocity, will still continue at interior points of the ice sheet base. Selective linear erosion, erosion by glacial-fed streams and massive flooding associated with ice dam failures may be the exception to this rule. Some suggested rates are presented in subsequent discussion of the geomorphic events submodel. Pressurized Recharge

Figure 20 illustrates a mass of ice superimposed on a repository sited in a basin and/or ice superimposed on a major recharge area of a deep aquifer underlying the basin. The recharge areas are presumed to be closer to major topographic highs and therefore more susceptible to alpine glaciation. As mentioned previously, the estimated probabilities for loading of the basin and 


\section{WET-BASED GLACIAL RECHARGE}

(2) GLACIATED

(1) GLACIATED LOWLAND UPLAND

BASIN AREA

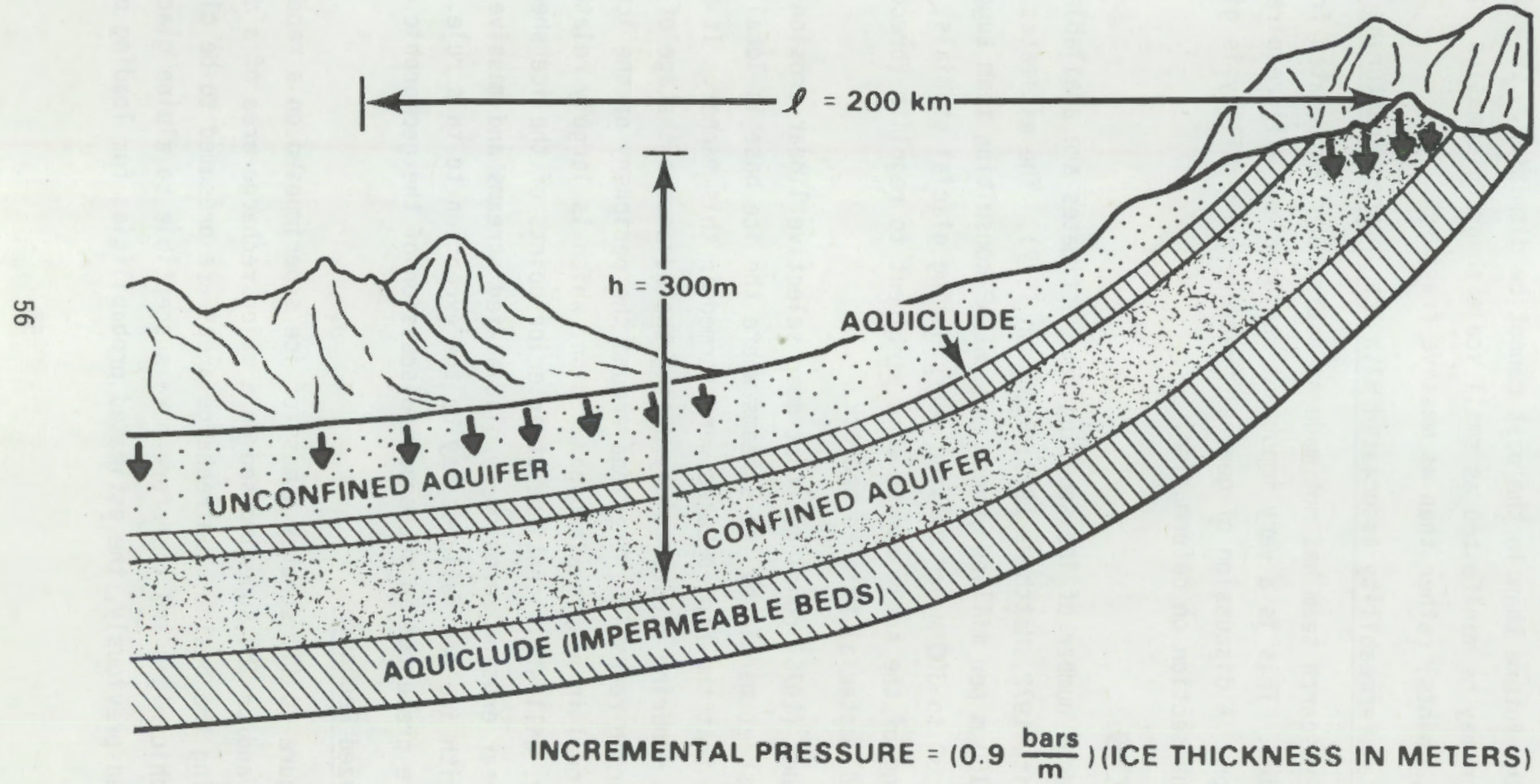

FIGURE 20. Conceptualization of Glacial Recharge of Ground water 
recharge areas are $10^{-7}$ per year and $10^{-5}$ per year respectively. Calculating the expected time ratio of continental ice loading to ice free conditions, the cumulative probability values for $10^{6}$ years are estimated as 0.10 and 0.90 , respectively.

A possible point of concern is how such ice accumulation might perturb the subsurface hydrologic regime. If the ground beneath the glacial ice is frozen, recharge to the aquifers will effectively cease. If, on the other hand, the geothermal heat flow and/or frictional heating are such that wet-based glacial conditions are supported, then between 2 and 5 centimeters per year of water will be available for recharge on a continual basis. (a) This water will be under considerable pressure because of the weight of the ice column above it. In general, this factor will be 0.09 bars per meter of ice. The most significant unknowns are the variations in the geothermal heat flow and frictional heating and their relationship to the thawing of the glacier base.

$\mathrm{Bu}_{1}{ }^{(\mathrm{a})}$ reports that the average geothermal heat flow is $1.2 \times 10^{-6}$ cals $\mathrm{cm}^{-2} \mathrm{sec}^{-1}$ but suggests that this value be doubled because much of the Cordilleran ice sheet was over a relatively active tectonic area. Frictional heating might result in an additional factor of two increase in heat available to basal melting. The research team concludes that at some point in its life, every area of the ice sheet will be wet based, and therefore pressurized recharge is a near certainty at some point in time if an area is ice covered. At the repository site, this would be manifested as recharge to the unconfined aquifer and also as a change in the elevation of the water table relative to the land surface.

At the recharge areas of the shallow and deep conf ined aquifers, pressurized recharge might occur if the area was totally ice covered and if ice toe drainage was not exceptionally high. For example, if the ice were 500 meters in thickness, the pressurization would be approximately 45 bars, or 45 times as great as it is presently. This might have an effect on the flow conditions

(a) Bull's work is reported in part in this report. A summary of his research has been published (Bull 1979). 
in the aquifers associated with the repository. The increased head, however, will not necessarily increase the hydraulic gradients in the aquifers. The extent, magnitude, and direction of these gradients are difficult to predict, but are critical to the model. It is interesting to speculate on the potential consequences associated with spatially differing recharge areas for the different aquifers. It may be possible to enhance the fluid potentials and flow velocities in one aquifer and not affect a deeper or shallower aquifer.

One of the strongest arguments for such pressurized recharge and total saturation of the ground is glacial sliding, which can only occur under wetbased and saturated conditions. (a) Since considerable evidence for sliding is available, recharge and saturation appear to be a near certainty for at least a part of the time an area is ice loaded. Similar recharge and saturation would occur if an area were flooded by a lake. The primary difference between the respective recharge pressures would be due to the density difference between ice and water. Beneath the lake, the pressure for recharge would be about 0.11 bars per meter of water depth and 0.09 bars per meter of ice thickness for wet-based glaciers.

Drainage of Meltwater

The dramatic effects of large and even catastrophic discharges of glacial meltwater is in no place better demonstrated than in the scablands region of the Pacific Northwest. A subsequent section is devoted to a discussion of Columbia River flows from current levels, up to levels associated with Missoula-type flooding which resulted from the failure of ice dams impounding up to $2 \times 10^{3} \mathrm{~km}^{3}$ of water. Baker (1973) estimates that Missoula flood waters passed through Wallula Gap at a rate of approximately $9.06 \times 10^{6} \mathrm{~m}^{3} \mathrm{~s}^{-1}$. Erosion, sedimentation, lake impoundment and potential river course alterations will be covered in this later section. To lend perspective, Figure 21 presents some estimated annual average Columbia River flows for the case of:

(a) Bull's work is reported in part in this report. A summary of his research has been published (Bull 1979). 


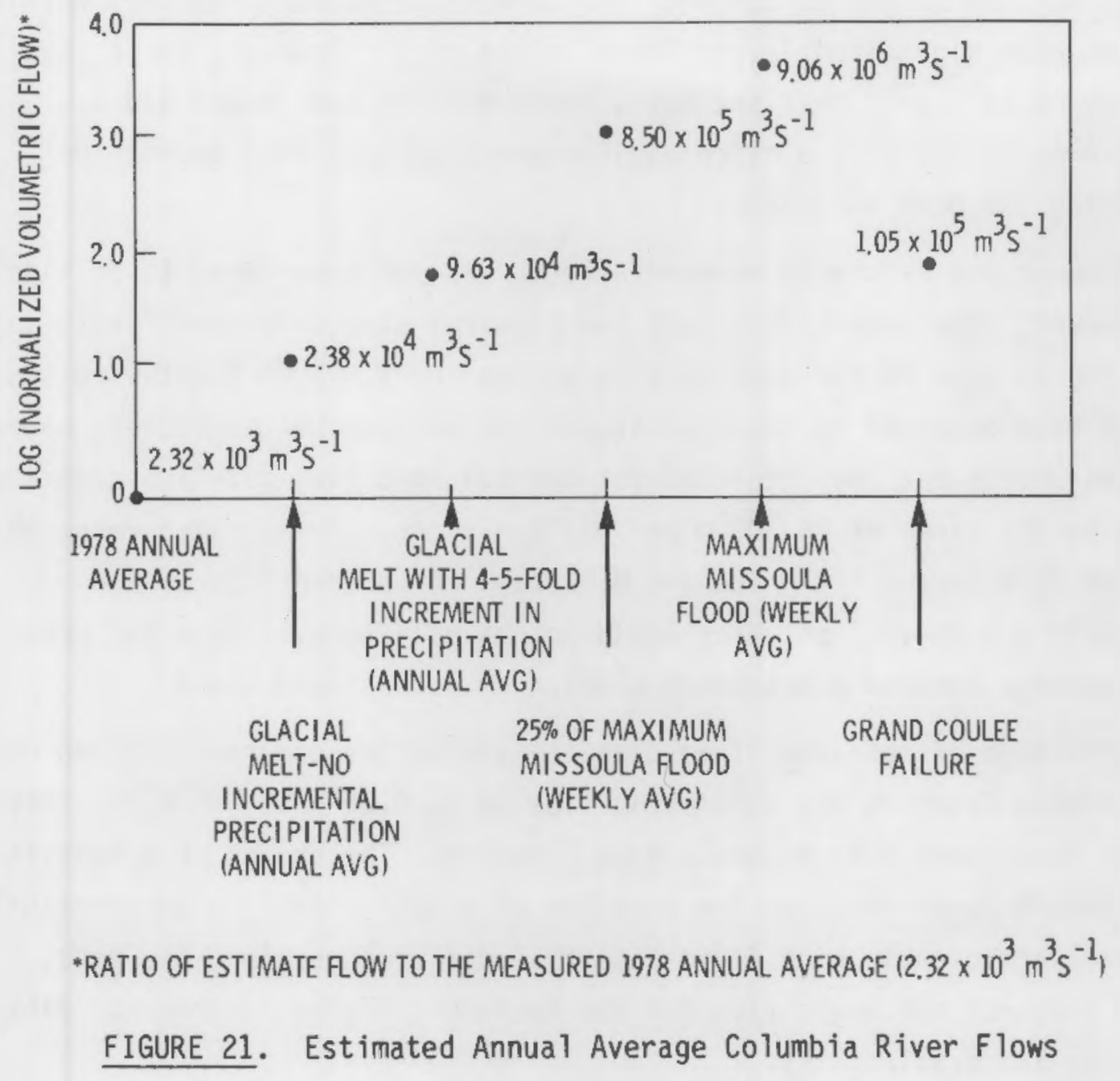

1) ice ablation (melting) with today's precipitation, 2) ice ablation with a four- to five-fold increase in precipitation, and 3) various levels of ice dam failures.

\section{Summary}

In summary, should continental glaciation occur in the future, it could potentially affect: subsidence, crustal fracturing, material scouring, pressurized recharge of aquifers, surface water flow, selective stream erosion, and sedimentation. In this model, the frequency of continental glaciers is determined by the temporal variations in climate. Future southerly advance of large ice sheets will be based on past advances, but may potentially exceed 
the Kansan advance by 400 to $600 \mathrm{~km}$. The Columbia Plateau in eastern Washington has not been significantly glaciated in the past. However, there is a probability of $10^{-7} \mathrm{yr}^{-1}$ that the Pasco Basin will be ice loaded and a $10^{-5} \mathrm{yr}^{-1}$ probability that a major aquifer recharge area will become ice loaded during the next $10^{6}$ years.

Subsidence and isostatic rebound effects are not considered to be significant. However, some potential exists for flexural stress-induced fracturing within a $200 \mathrm{~km}$ zone of the edge of a large ice sheet. Such fracturing has apparently been observed in the midwest and the eastern United States; however, no such phenomenon has been reported for the Columbia Plateau. Ice scouring rates are in the range of 30-300 $\mathrm{m}$ per million years. Pressurized recharge would be at 0.09 bars $\mathrm{m}^{-1}$ for ice and 0.11 bars $\mathrm{m}^{-1}$ of depth for water. Approximately 2-5 $\mathrm{cm} \mathrm{yr}^{-1}$ of water would potentially be available for pressurized recharge beneath a wet-based glacier on a continual basis.

The drainage of meltwater from glaciers and/or ice dam failures can occur in the Columbia River as any volumetric flow up to $9.06 \times 10^{6} \mathrm{~m}^{3} \mathrm{~s}^{-1}$. This maximum is associated with Missoula-type flooding. The breach of a repository within a basalt layer requires the creation of a sufficiently high permeability pathway and sufficiently high fluid potential differences along the path. Figure 22 presents the logic flow for the submodel. Table 13 presents data requirements and availability.

\section{ALPINE GLACIATION}

Several of the potential consequences of alpine glaciation are similar to those associated with continental glaciation. A differentiation has been made in this report because mountain glaciers from eastern and western topographic highs have approached the Columbia Plateau to within a few tens of kilometers (Bul1 1979). Furthermore, aquifer recharge areas are more likely to be affected by such glacial advances. Figure 23 shows the extent of these ice masses during a glacial period some 18,000 years ago. The research team suggests that future advances may be more extensive than those of the past. 


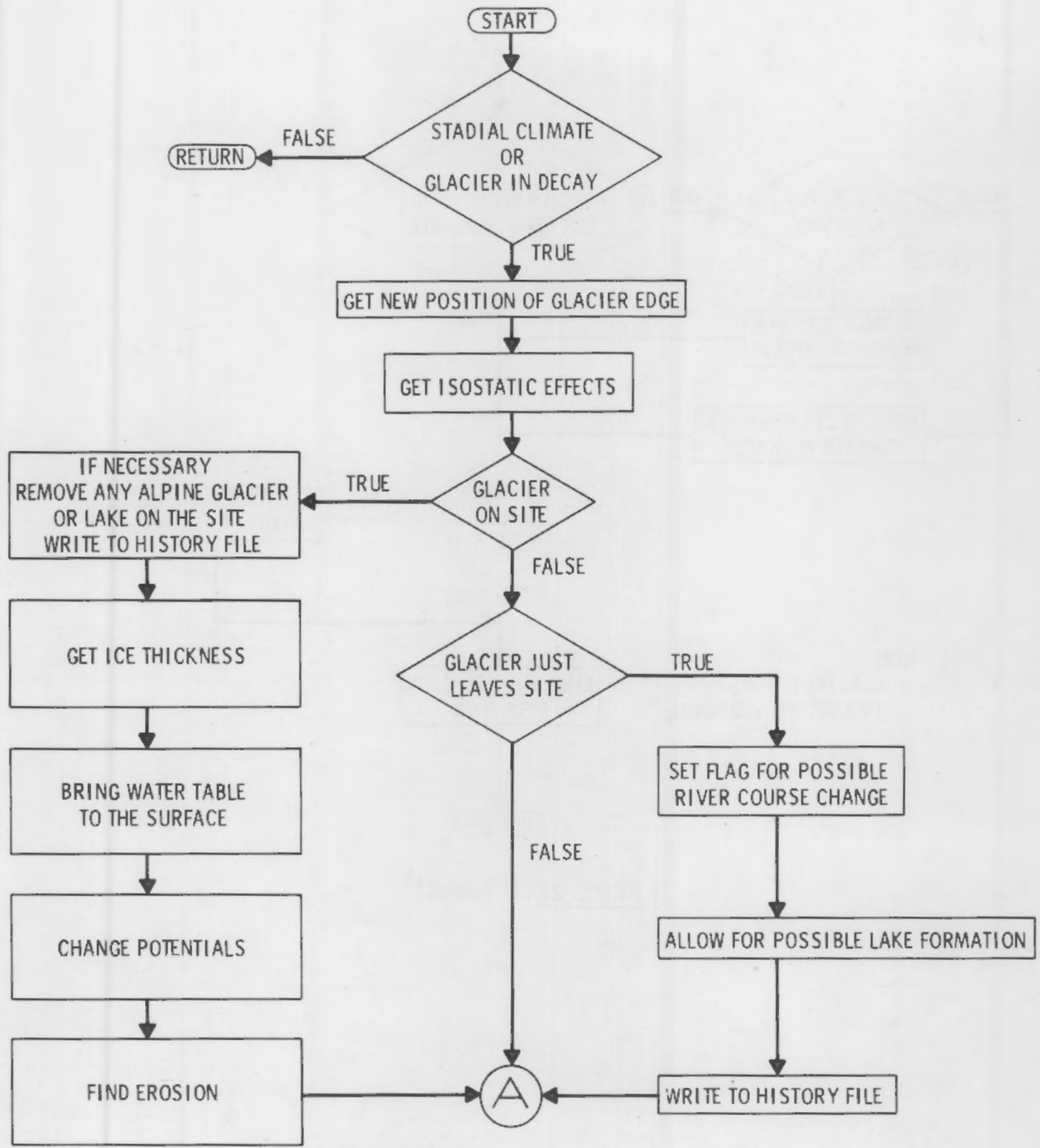

FIGURE 22. Continental Glaciation Logic Flow Chart 


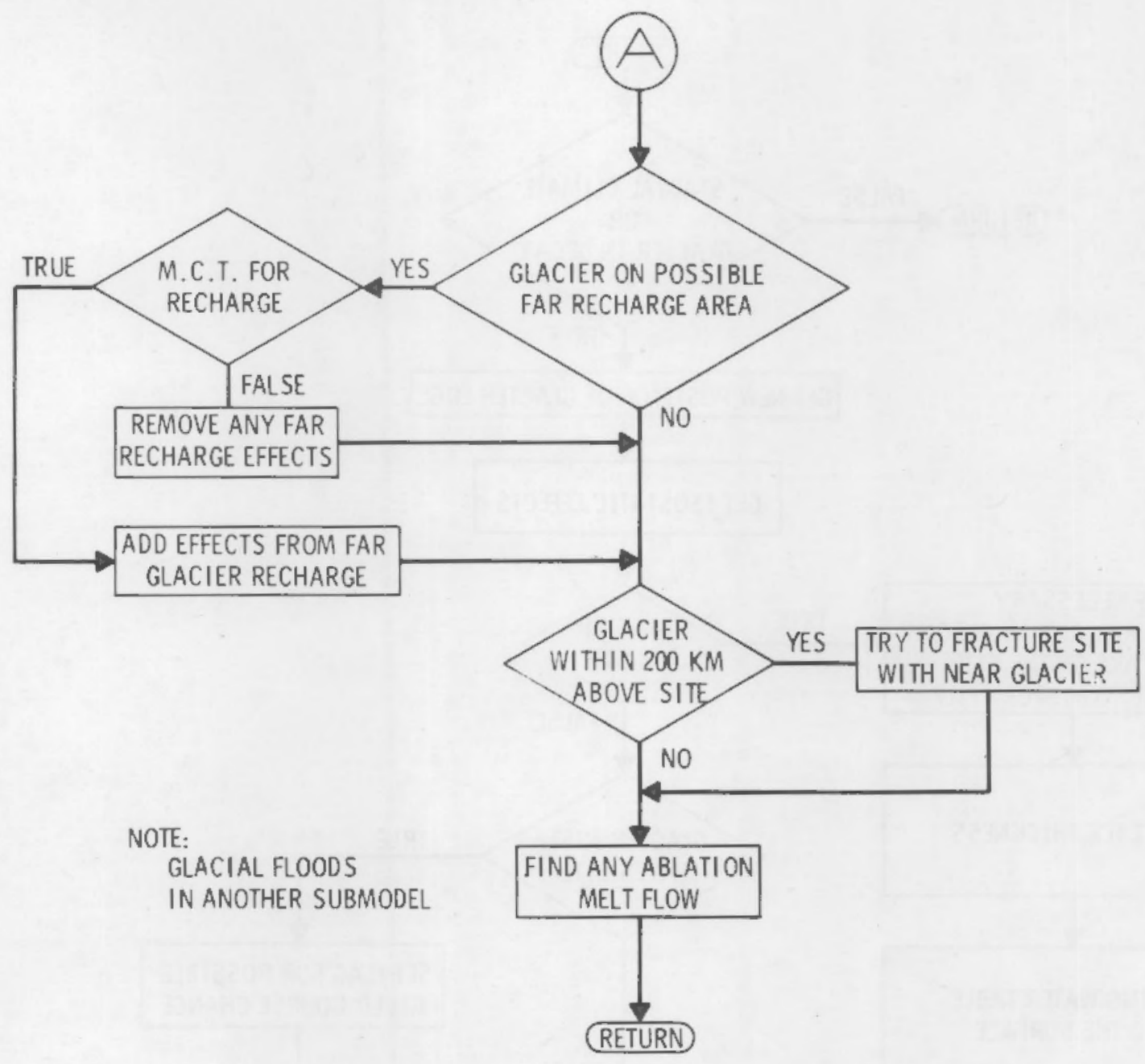

FIGURE 22. (cont) 
TABLE 13. Continental Glaciation Submodel Data(a)

SUBJECT

ILLUSTRATIVE

COMMENTS

GRAPHICAL REPRESENTATION OR DATA

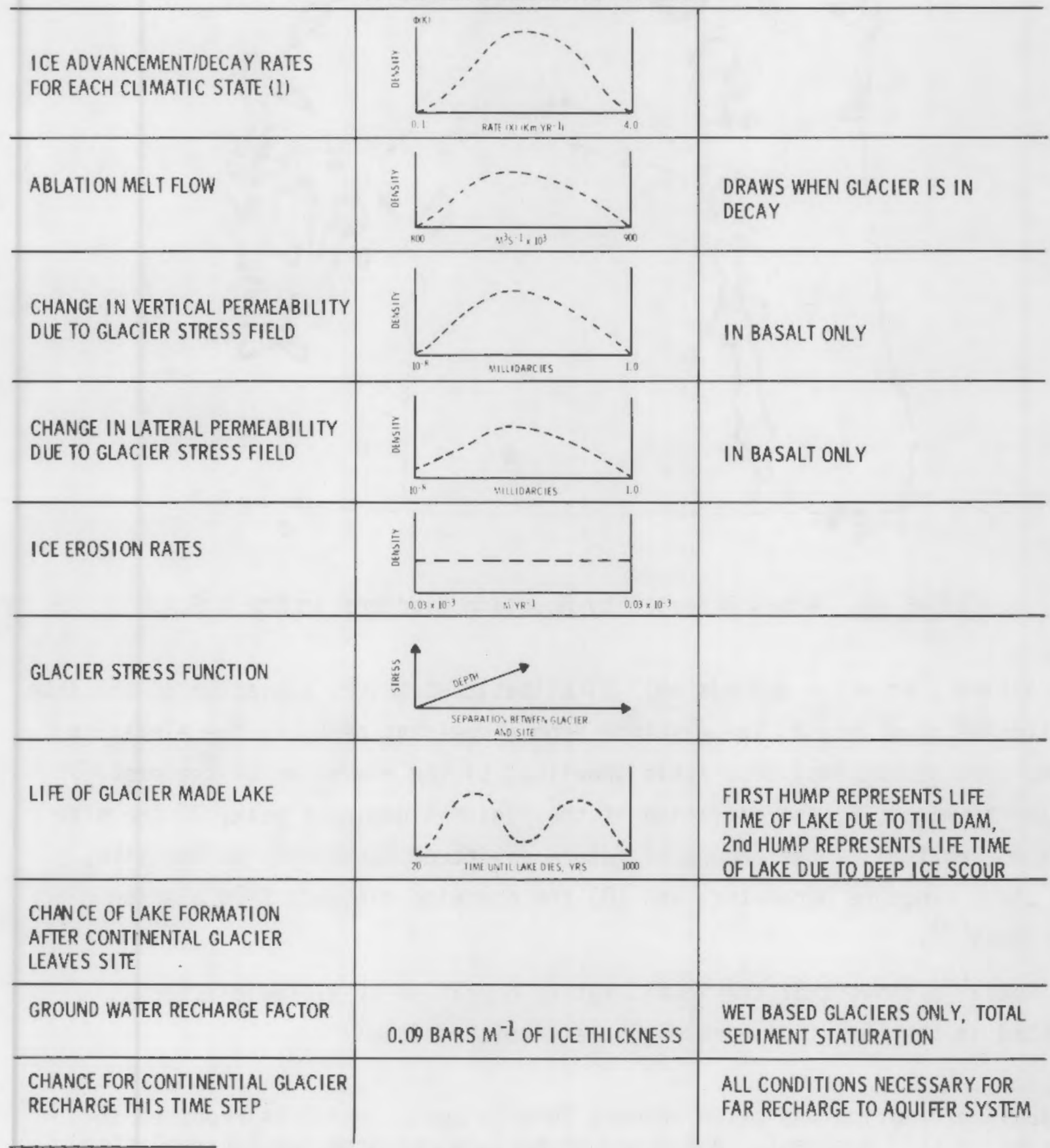

(a) Data is under development and is not available at this time. 


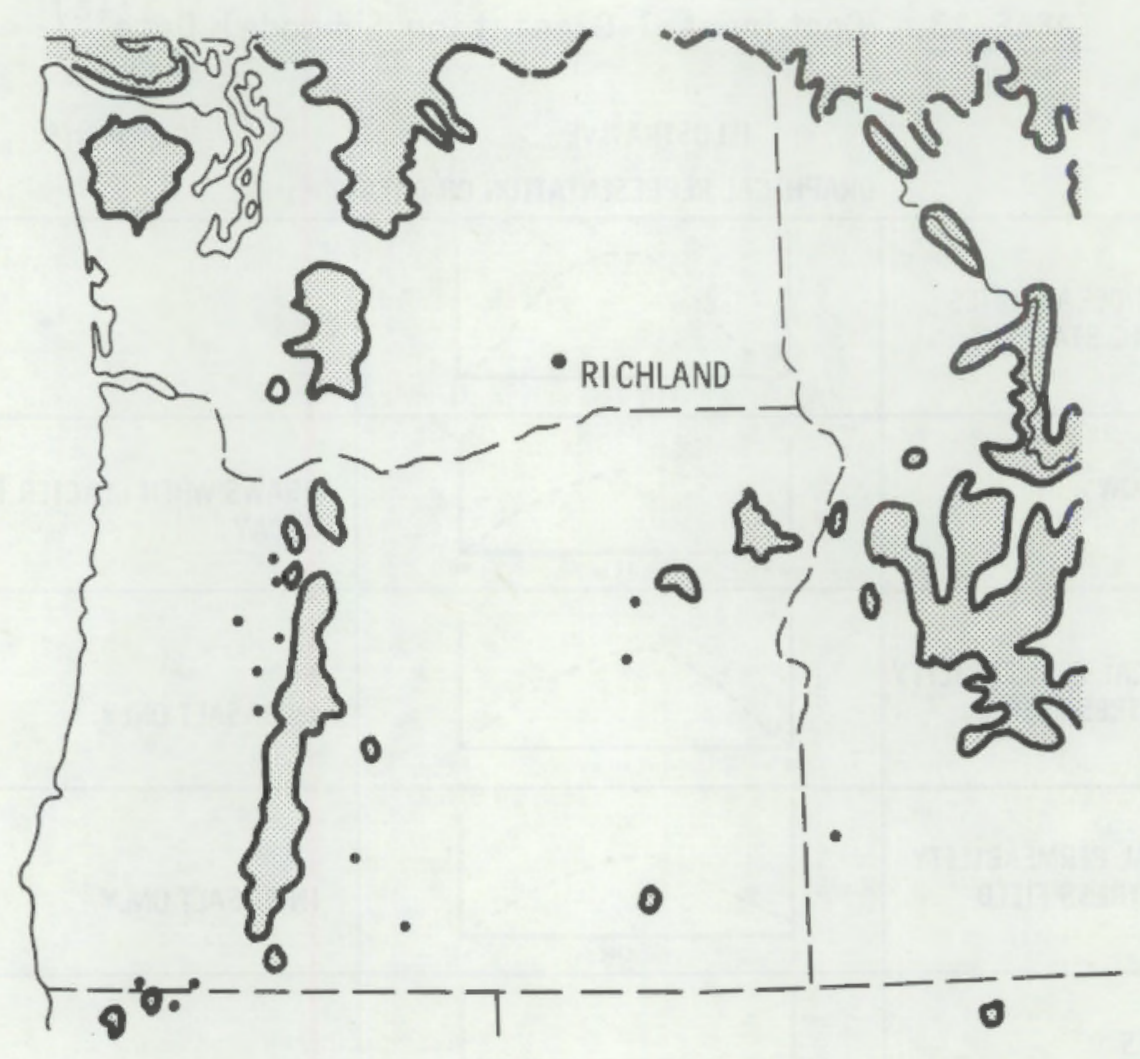

FIGURE 23. Areas Affected by Mountain Glaciers in the U.S.A.

Alpine glaciation depends on: 1) climatic state, 2) elevation of the late Pleistocene snowline, 3) the distance from a dominant peak, 4) the elevation of the present regional orographic snowline, 5) the elevation of the past glacier terminal, 6) the elevation of the regional dominant peak, 7) the site surface elevation 8) the amount of future uplift or subsidence of the site, 9) a slope exposure parameter, and 10) the downwind distance from a major water body ${ }^{(a)}$.

Kukla ${ }^{(a)}$ shows that the lowest future elevation of alpine glaciers, expected in the next $10^{6}$ years might be predicted from:

(a) This information was based on work done by Kukla, which is reported in part in this document. A summary of Kukla's research has ben published (Kukla 1979). 


$$
z g_{\min }=z_{s}-1.25\left(z_{s}-z_{p}\right)-h_{u}-\left(z_{p} 1-z_{g}\right) \text { with } P_{\min }
$$

where

$$
\begin{aligned}
Z g_{\min } & =\text { lowest future elevation of mountain galciers } \\
Z_{s} & =\text { present regional snowline elevation } \\
Z_{p} & =\text { a recorded late Pleistocene snowline elevation } \\
h_{u} & =\text { an anticipated uplift } \\
Z_{p} 1-Z_{g} & =\text { a cumulative probability distribution } \\
P_{\min } & =\text { ALCLIN values }
\end{aligned}
$$

The maximum uplift for mountains and valleys are estimated to be $1000 \mathrm{~m}$ and $500 \mathrm{~m}$ respectively over a $10^{6}$ year period. The probability distribution of a site being alpine glaciated as a function of the distance from a dominant peak is given in Figure 24.

Several of the potential consequences associated with alpine glaciation are quite similar to those of continental glaciation and will not be repeated. Major difference is that continental glaciers generally occupy the lower elevations first, e.g., below $2500 \mathrm{~m}$ in Canada during the last epoch. Their effects on crustal loading are less, and because they occupy mountainous bedrock areas which tend to have relatively low permeabilities, direct recharge from their bases is of less importance. Alpine glaciers, as the name implies, are initiated at significant elevations and descend down the slopes of the topographic highs.

\section{Summary}

Alpine glaciation estimates are based on the climatic state, the elevation of the late Pleistocene snowline, the distance from a dominant peak and the elevation of the peak, the site surface elevation, and the downwind distance form a large body of water. Figure 25 presents the logic flow diagram for alpine glaciation. Data requirements and availability are illustrated in Table 14 . 


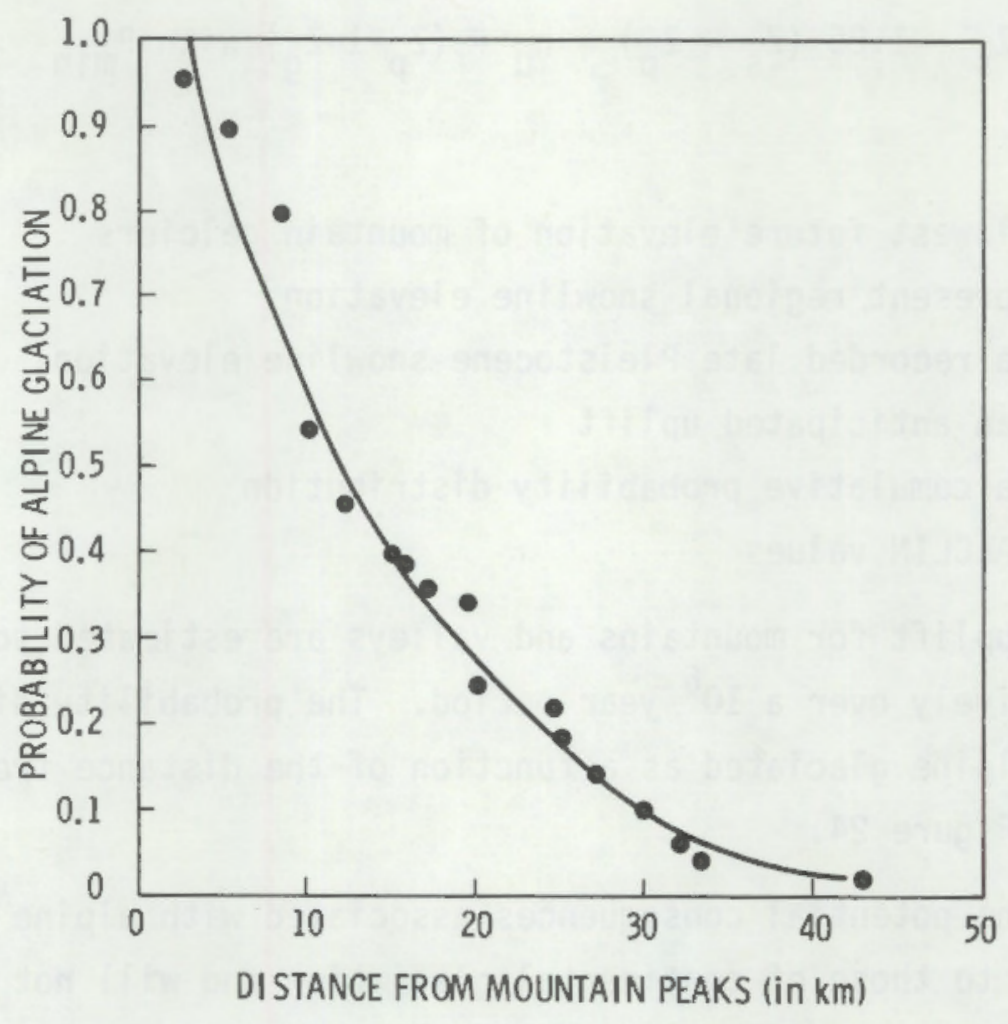

FIGURE 24. Probability of Alpine Glaciation in the Great Basin as a Function of Distance from a Dominant Peak(a)

\section{SEA LEVEL FLUCTUATIONS}

This section briefly discusses how the ocean level might change during the next $10^{6}$ years, and how such changes might affect the Columbia Plateau. Numerous variables influence sea level fluctuations. These include: 1) the galactic cycle, which is on the order of 200 to 250 million years; 2) paleogeography or continental drift; 3 ) earth orbital physics, with a 41,000 year cycle of axial tilt, a 21,000 year cycle of precession, and a 95,000 year cycle of orbital eccentricity; and 4) the solar cycle, with its variable sun spot density (Schwartz 1979).

(a) This information was based on work done by Kukla, which is reported in part in this document. A summary of Kukla's research has been published (Kukla 1979). 


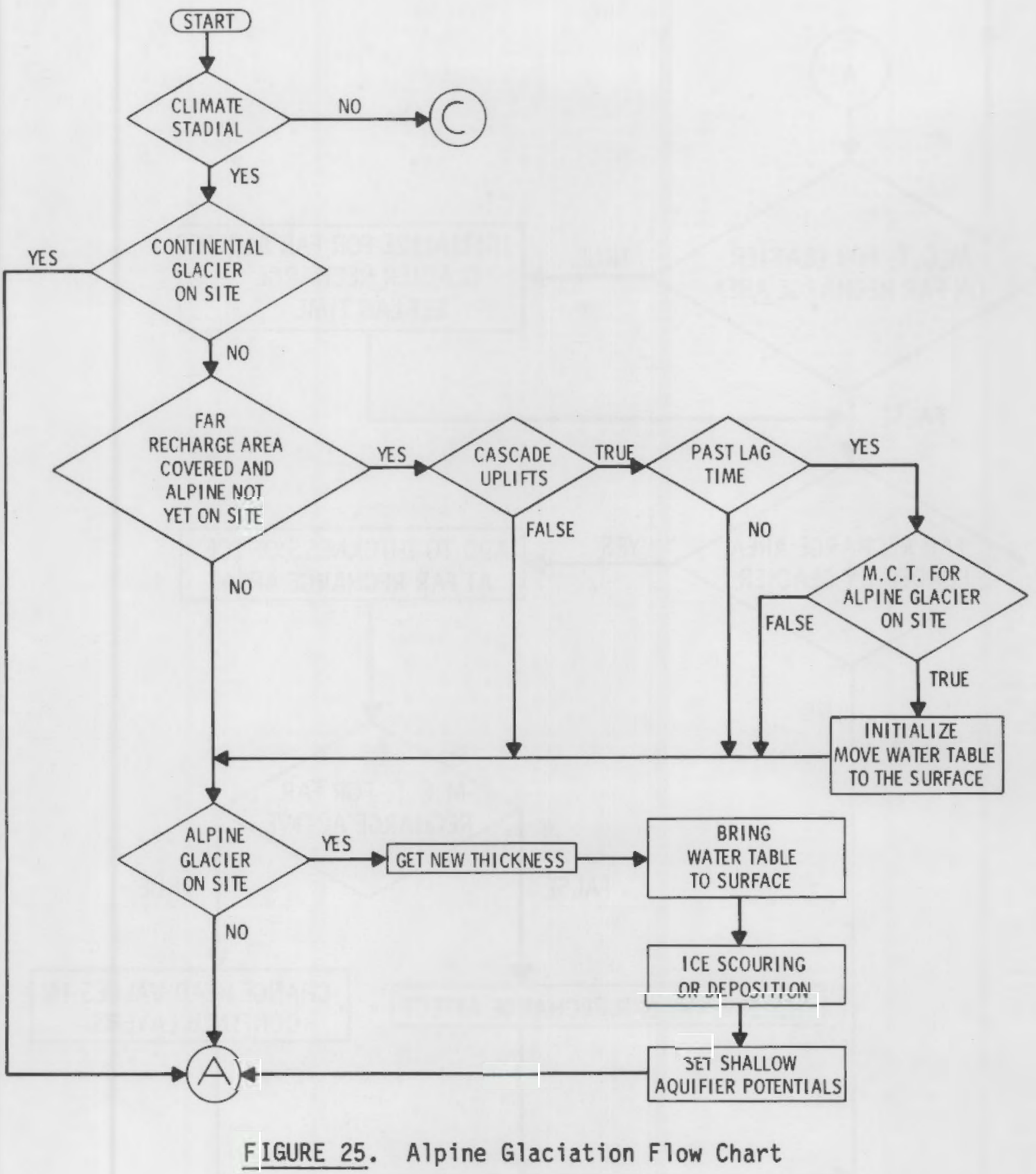




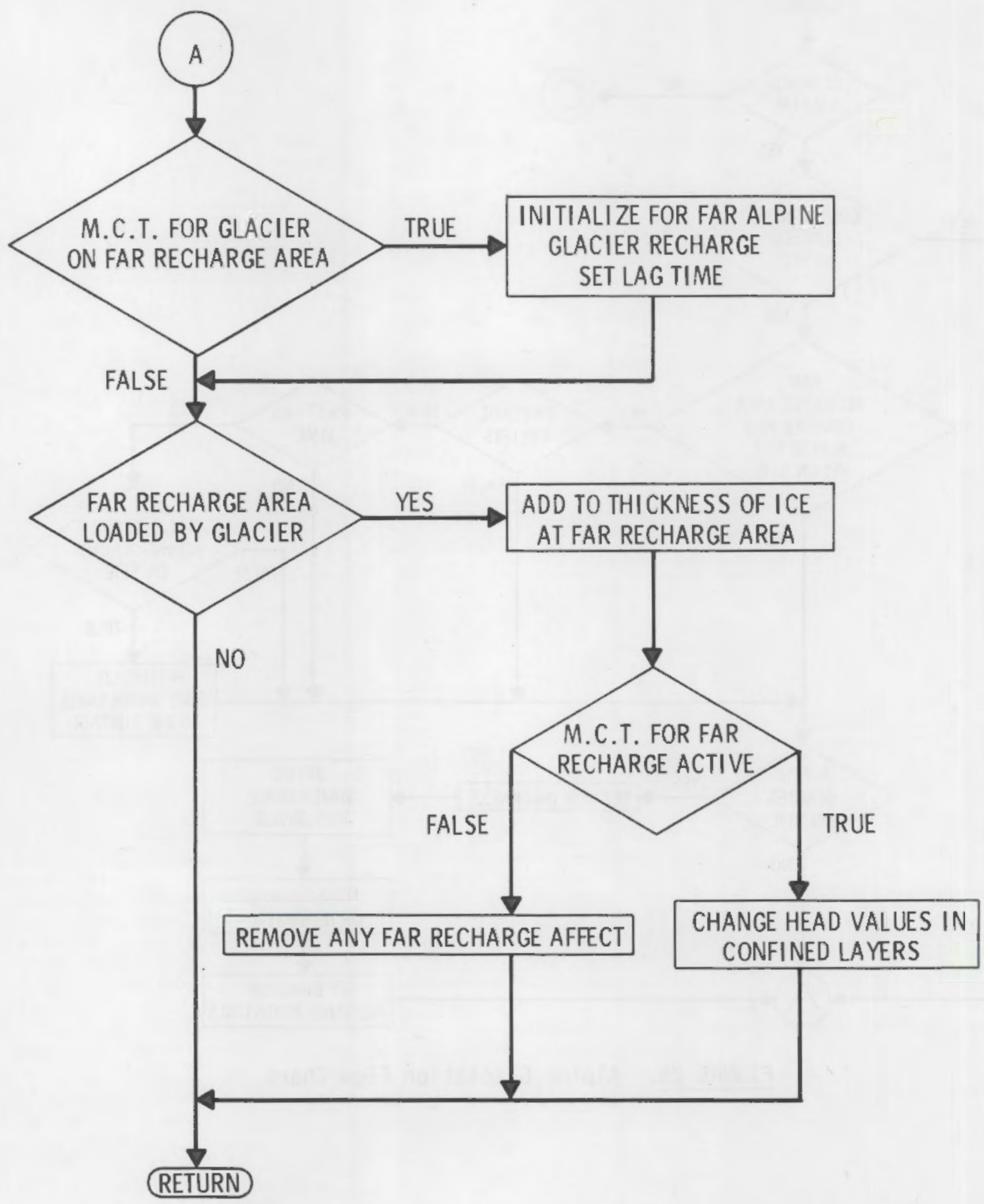

FIGURE 25. (contd) 


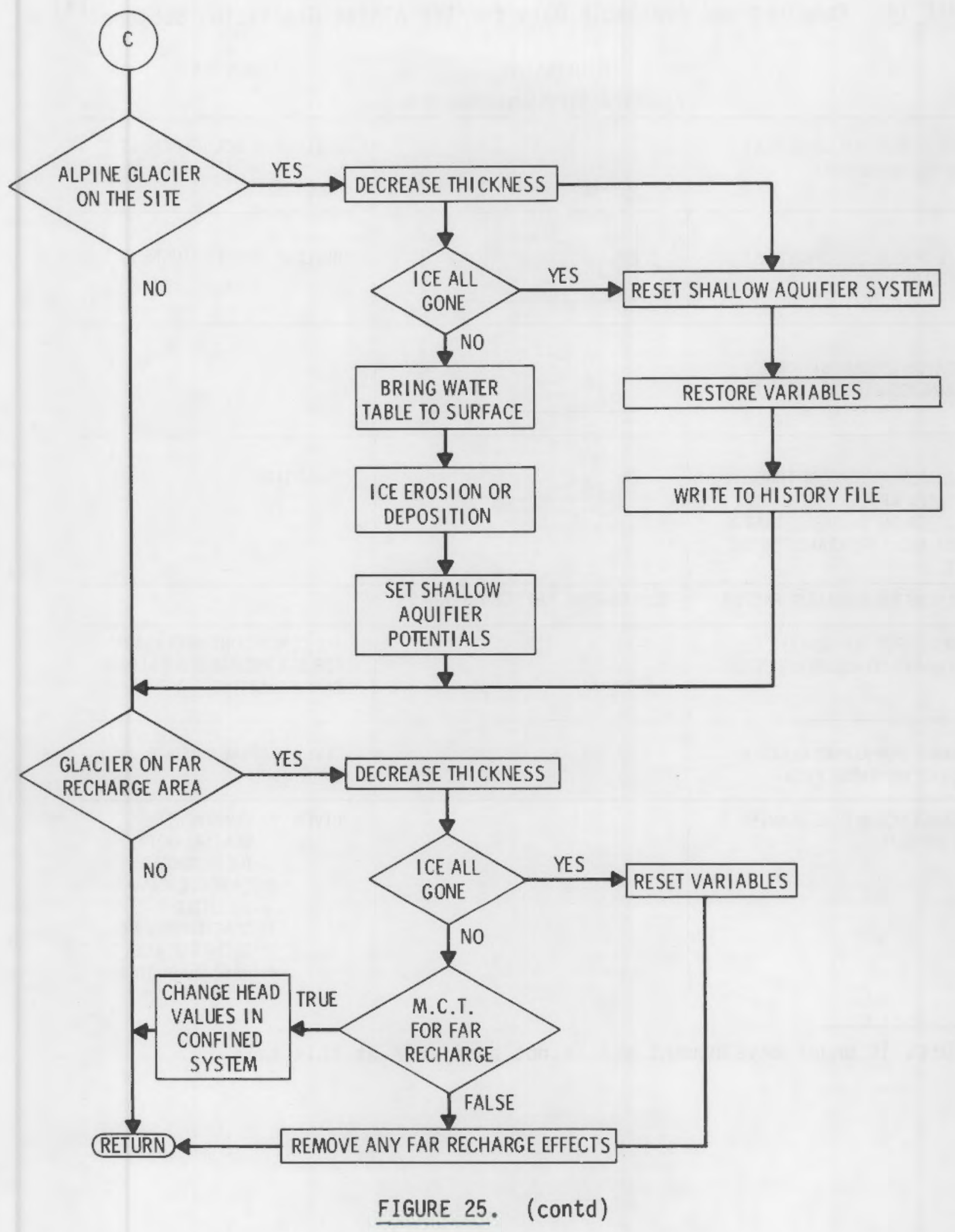


TABLE 14. Required and Available Data for the Alpine Glaciation Submodel (a) SUBJECT

ILLUSTRATIVE COMMENTS

GRAPHICAL REPRESENTATION OR DATA

\begin{tabular}{|c|c|c|}
\hline $\begin{array}{l}\text { RATE OF GLACIER GROWTH AT } \\
\text { FAR RECHARGE AREA }\end{array}$ & 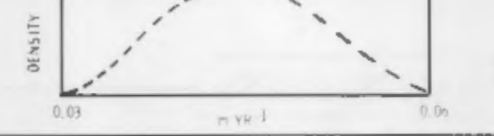 & BUILDUP OF ICE THICKNESS \\
\hline $\begin{array}{l}\text { RATE OF GLACIER GROWTH AT } \\
\text { THE SITE }\end{array}$ & 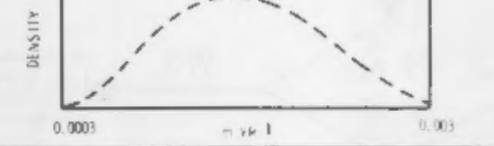 & BUILDUP OF ICE THICKNESS \\
\hline $\begin{array}{l}\text { EROSION OR DEPOSITION BY } \\
\text { ALPINE GLACIER AT THE SITE }\end{array}$ & $\underbrace{[-,-\infty+\cdots}_{0.003}$ & \\
\hline $\begin{array}{l}\text { MINIMUM AMOUNT OF TIME } \\
\text { BETWEEN APPEARANCE OF THE } \\
\text { GLACIER ON THE FAR RECHARGE } \\
\text { AREA AND APPEARANCE ON THE } \\
\text { SITE }\end{array}$ & & "LAG" TIME \\
\hline PRESURIZED RECHARGE FACTOR & 0.09 BARS $M^{-1}$ OF ICE THICKNESS & \\
\hline $\begin{array}{l}\text { CHANCE FOR FAR GLACIER } \\
\text { RECHARGE TO AQUIFER SYSTEM }\end{array}$ & & $\begin{array}{l}\text { ALL CONDITIONS NECESSARY } \\
\text { FOR FAR RECHARGE BY ALPINE } \\
\text { GLACIER ACTIVE }\end{array}$ \\
\hline $\begin{array}{l}\text { CHANCE FOR ALPINE GLACIER } \\
\text { ON FAR RECHARGE AREA }\end{array}$ & & GIVEN STADIAL CLIMATE \\
\hline $\begin{array}{l}\text { CHANCE FOR ALPINE GLACIER } \\
\text { AT THE SITE }\end{array}$ & & $\begin{aligned} &\text { GIVEN: } 1) \text { CONTINENTAL } \\
& \text { GLACIAL NOT } \\
& \text { THERE ALREADY } \\
& \text { 2) } \text { CASCADES HAVE } \\
& \text { UP LIFIED } \\
& \text { 3) } \text { GLACIER ON FAR } \\
& \text { RECHARGE AREA } \\
& \text { 4) PAST "LAG" TIME }\end{aligned}$ \\
\hline
\end{tabular}

(a) Data is under development and is not available at this time 
All of these factors affect the state of world eustacy which is subdivided into glacio-eustacy, a change in the quantity of water, and tectono-eustacy, a change in the shape and volume of the container or ocean basin (Schwartz 1979). Table 15 lists the magnitude and rate of change associated with both glacioand tectono-eustatic changes of sea level for periods of $10^{5}$ and $10^{6}$ years, respectively. Like glaciers, ocean levels may go through several cycles in a $10^{6}$ year time frame.

At present, the sea leve 1 is rising at $3-4 \mathrm{~mm} \mathrm{yr}^{-1}$ (1-2 $\mathrm{mm} \mathrm{yr}^{-1}$ glacioeustatic and $2 \mathrm{~mm} \mathrm{yr}^{-1}$ subsidence). A short term maximum rate of ocean leve 1

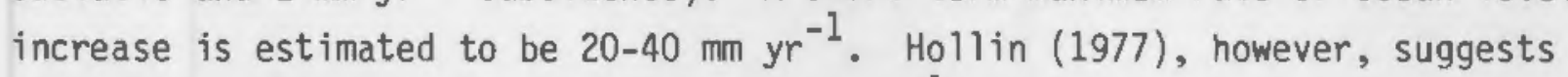

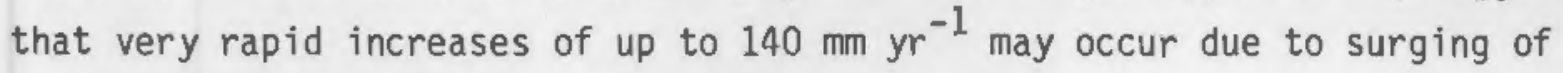
major parts of the Antartic ice sheet.

The land surface near the center of the Pasco Basin is about 120 meters above sea level. The upper surface of the underlying basalt is as much as 80 meters below sea level. Inundation by the ocean or backup of the Columbia and Snake Rivers is conceivable, especially if additional erosion and/or subsidence of the area occur. If such inundation were to occur it would probably result in: 1) sedimentation, 2) total saturation of the sediments, and 3) substantial lowering of shallow aquifer gradients.

Ocean level fluctuations, coastal erosion, sedimentation, and sediment saturation are not particularly significant with respect to a repository buried at a depth of 300 meters or more in basalt. However, such perturbations to the topography and subsurface hydraulic gradients should be included for completeness. Figure 26 presents the general logic flow diagram for this submodel. The data requirements and availability are shown in Table 16.

\section{GEOMORPHIC EVENTS}

This submodel examines the following topics: 1) Columbia River and tributary flow as a function of precipitation and glacial meltwater runoff,

TABLE 15. Potential Ocean Level Variations

$\begin{array}{llll}\frac{\text { Type }}{\text { Glacio-eustatic }} & \frac{\text { Amount }}{100 \mathrm{~m}} & \frac{\text { Range }}{200 \mathrm{~m}} & \frac{\text { Rate }}{10^{5} \mathrm{yrs} \text { per cycle }} \\ \text { Tectono-eustatic } & 250 \mathrm{~m} & 500 \mathrm{~m} & 10^{6} \mathrm{yrs} \text { per cycle }\end{array}$




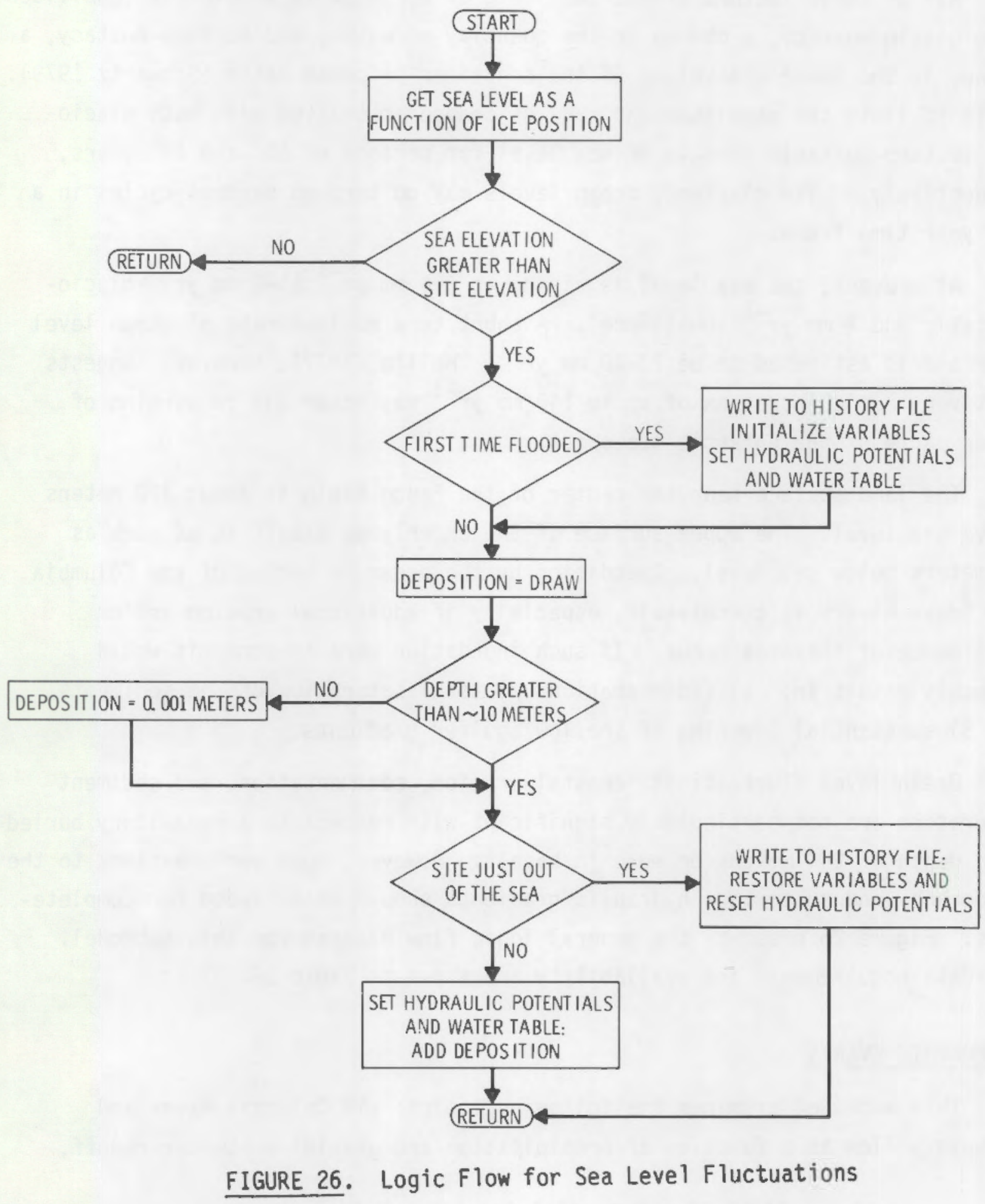


TABLE 16. Sea Level Fluctuation Sub Model Data

SUBJECT

ILLUSTRATIVE

COMMENTS

GRAPHICAL REPRESENTATION OR DATA

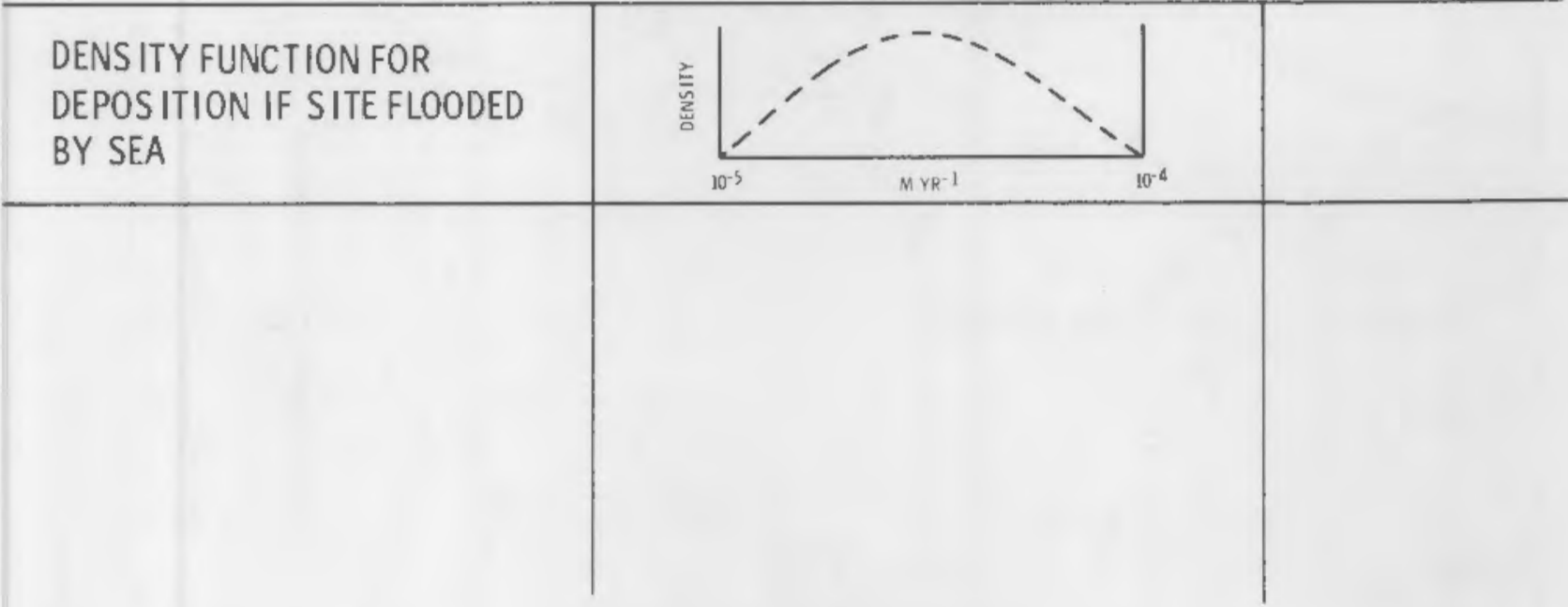

2) flooding of the basin as a function of river flow and the relative elevation difference between Wallula gap (a likely location of hydraulic damming during catastrophic flooding, Figure 17) and the ground surface above the repository, 3) sedimentation in a low energy lake environment, 4) recharge to the unconfined aquifer zone, 5) potential river course alterations caused by sediment infilling, and 6) stream erosion during initial and final stages of flooding and stream erosion and deposition in general.

\section{River Flows}

River flow in the Columbia is considered to be a superposition of surface runoff from: 1) precipitation over the watershed, 2) average ice ablation, and 3) catastropic ice dam collapse. The values assigned to these variables come from the submodels on climate and continental glaciation. Figure 27 shows the extent of glacial ice 18,000 years ago.

Table 17 shows the ranges of annual average Columbia River flows based precipitation, ice melting, and ice dam collapse. Past experience with river hydrographs has shown that the mean annual flow ranges from 25 to $40 \%$ of the peak flow (Leopold et al. 1964). This relationship is considered in the submode?. 


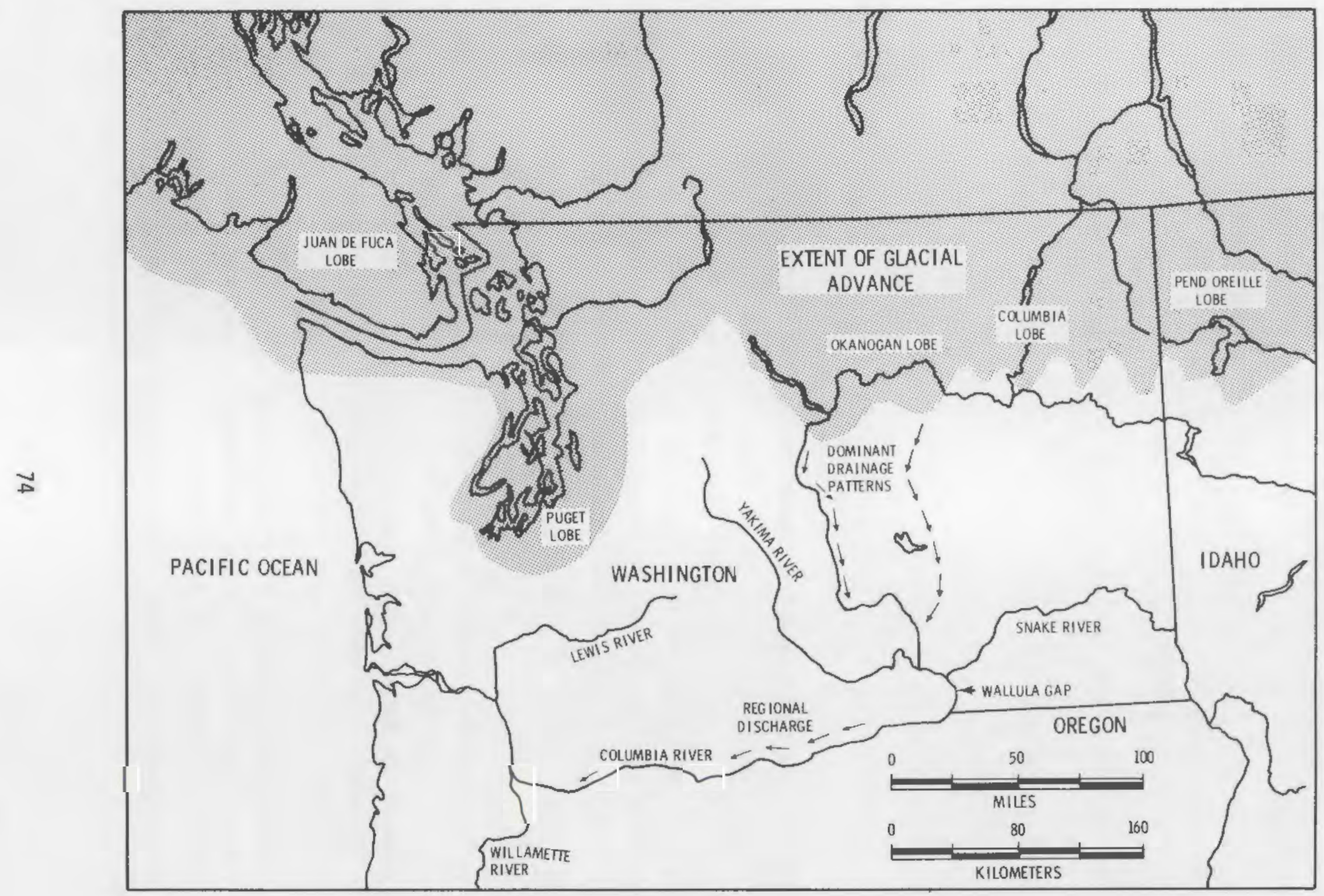

FIGURE 27. Assumed Extent of Glacial Advance 18,000 B.P. 
IABLE 17. Ranges of Average Annual Columbia River Flow

\begin{tabular}{|c|c|c|}
\hline Estimated Flow & $\begin{array}{c}\text { Discharge af Hanford } \\
\mathrm{m} \text { sec }\end{array}$ & $\begin{array}{c}\text { Ratio to Columbia River } \\
\text { Mean Annual Flow }\end{array}$ \\
\hline $\begin{array}{l}\text { Columbia River } \\
\text { Average Annual Flow }\end{array}$ & $3.43 \times 10^{3}$ & 1 \\
\hline $\begin{array}{l}\text { Glacial Melt } \\
\text { (annual average) }\end{array}$ & $2.38 \times 10^{4}$ & 7 \\
\hline $\begin{array}{l}\text { Glacial Melt with a } \\
\text { Factor of } 4 \text { Increase } \\
\text { Increase in Precipitation } \\
\text { (annual average) }\end{array}$ & $9.63 \times 10^{4}$ & 28 \\
\hline $\begin{array}{l}\text { Maximum Flood Associated } \\
\text { with Ice Dam Collapse } \\
\text { (weekly average) }\end{array}$ & $9.06 \times 10^{6}$ & 2645 \\
\hline
\end{tabular}

Catastrophic river flows caused by rapid drainage of large ice-dammed lakes occurred at a rate of $5 \times 10^{-5} \mathrm{yr}^{-1}$ (Bretz 1969) during previous glacial episodes. A classic example is the series of Missoula or scabland floods that have occurred in eastern Washington from the repeated collapse of large ice dams in western Montana. Figure 28 shows the extent of a major Missoula ice dam flood. Missoula-like floods have in the past and will almost certainly inundate the Pasco Basin again. Such flooding occurred not only at the end of the glacial episodes, but also occurred as a result of ice-front fluctuations during glacial episodes. Extensive lobes of ice caused perhaps by changes in the basal thermal conditions formed around the periphery of the ice sheet. Some of the ice lobes dammed streams draining the upland areas and formed ice marginal lakes that trapped seasonal meltwater. The probability of such a flood occurring in the Columbia Plateau area during any 100-year period during or immediately following a glacial episode appears to be approximately $10^{-2}$ (Tubbs 1979).

Tubbs concludes that 7 to 9 major Missoula-type flooding episodes might occur in the Pasco Basin in the next $10^{6}$ years. However, many smaller floods from other impounded lakes are also likely. 


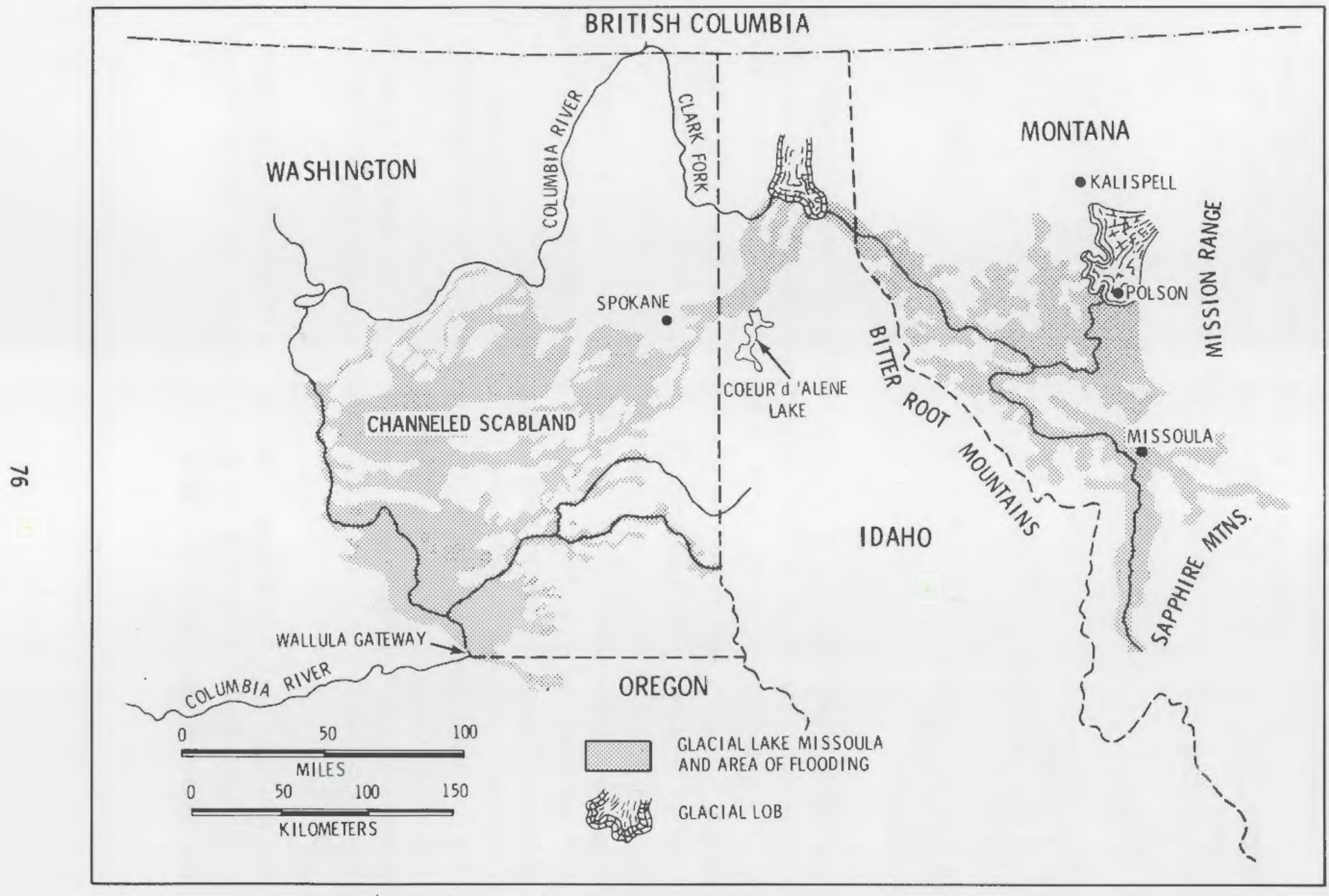

FIGURE 28. Extent of Missoula Flooding (after Thornbury, 1969) 


\section{Inundation of the Basin}

Flood waters associated with ice-dam failures have of ten been impounded in the Pasco Basin because of a hydraulic constriction of Wallula Gap. Given simular flood conditions it is probable that such impoundment will occur in the future. Wallula Gap is a deep cut through a basalt anticline, as is shown in Figure 29, which forms an effective hydraulic dam for the elevated flow rates associated with ice-dam failures. The maximum lake elevation resulting from such impoundment is $350 \mathrm{~m}$. This represents a volume of $730 \mathrm{~km}^{3}$ of water within the Pasco Basin alone. Estimates of the persistence of such lakes range from one day to two weeks with a few days to a week probably being the most reasonable figures (Tubbs 1979). Smaller lakes might be associated with smaller ice-dam failures.

An estimate of the discharge capacity of Wallula Gap is necessary to determine the critical flow below which high energy river flow and associated erosion are possible, and above which a lower energy lake environment with associated sedimentation will exist.

This submodel checks the calculated inflow into the Pasco Basin. If the inflow exceeds the maximum possible outflow at Wallula Gap $\left(9.06 \times 10^{6} \mathrm{~m}^{3} \mathrm{~s}^{-1}\right)$ a temporary lake forms in the basin due to hydraulic damming of Wallula Gap. Peak flows are used to compute erosion associated with the initial phase of such a flood.

Erosion and sedimentation therefore are functions of the river flow coming into the basin, the elevation of the ground surface above the repository, the lake elevation, and the flow at the wallula Gap discharge point. If sedimentation and erosion are such that the general topography of the Pasco Basin is not changed significantly, then Figure 30 would be applicable. This figure shows the approximate area of the Hanford Reservation inundated by flow of $2.97 \times$ $10^{6} \mathrm{~m}^{3} \mathrm{~s}^{-1}$ or about $33 \%$ of the maximum Missoula flood level.

Because of the buildup of ice during a glacial period, the sea level would be progressively lowered by as much as $100 \mathrm{~m}$, which in turn would lower the base level of the Columbia River. Thus, channel bed erosion would be initiated at the mouth of the river and continuously work its way back towards Wallula 

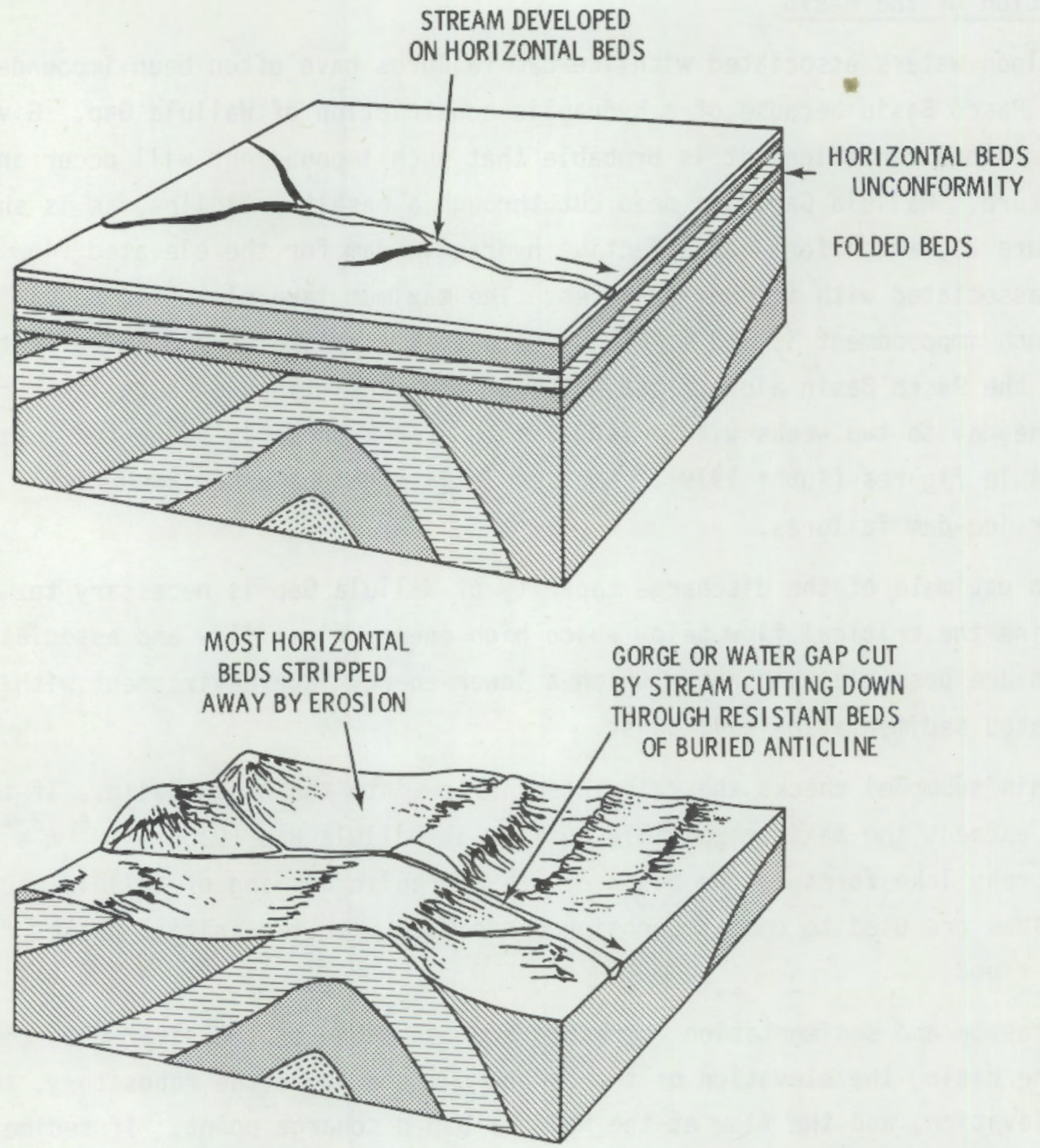

FIGURE 29. Development of a Hydraulic Constriction at Wallula Gap (Erosion May Require $10^{6}$ or More Years)

Gap. Side wall erosion as well as bed scouring may result in the elimination of the gap as a hydraulic dam. This would result in higher energy flows through the Pasco Basin and consequently enhanced erosion. Therefore, the potential for and magnitude of erosion of Wallula Gap is included in the model. 


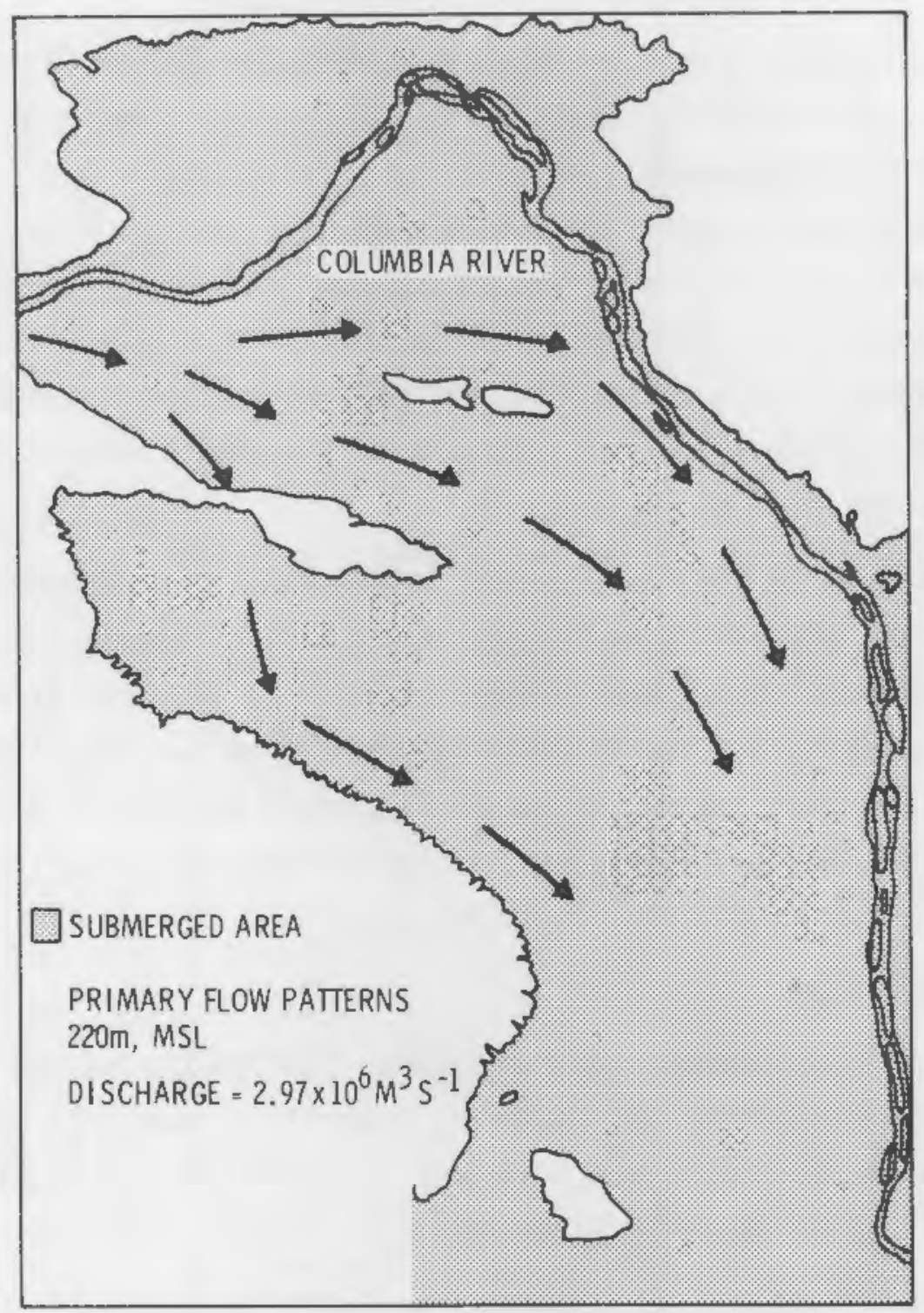

FIGURE 30. Approximate Area of Hanford Reservation Inundated by a Flow of $2.97 \times 10^{6} \mathrm{~m}^{3} \mathrm{~s}^{-1}$ (water surface elevation at $220 \mathrm{~m}$ present MSL)

\section{Recharge}

If a lake is created over the repository site, water at the bottom of the lake will be forced into the ground under a pressure of about 0.11 bars/meter of lake depth. As a result, the elevation of the water table may increase and the horizontal hydraulic gradients in the shallow unconfined aquifers may be reduced substantially. These effects may be negligible, however, due to the short duration of floodwater impoundment. 
Sedimentation

As the flood waters enter the Pasco Basin and the low energy lake environment, they lose their sediment transporting capability. Figure 31 shows the relationship between mean annual precipitation and maximum sediment load. Attempts are being made to generate similar curves relating Columbia River and tributary sediment loads as a function of volumetric flow or stream potential. The largest sediment load should be associated with the large Missoula-like floods. Flood waters are assumed to be at maximum sediment transport efficiency even though scouring of the scablands may become progressively more difficult with successive floods.

Flood deposition in the Pasco Basin, is greatest at the canyon and coulee mouths on the north and east sides of the basin, since these are the directions from which the dominant flows come. Such sediment buildup can affect the state of stress of the system and the vertical distance from the repository to the ground surface. It may also result in alteration of the course of the columbia River. This could reduce contaminant transport distances and potentially cause selective stream erosion over the repository.

\section{River Course Alteration}

The Columbia River, because of far greater runoffs during the Ice Age (Pleistocene Epoch) than now, is a markedly underfit stream. It occupies a well established and adjusted course so that it can handle at least several times its present flow rate without appreciable changes in its course.

Recognizable, systematic changes have occurred in the course of the Columbia River as it downcut its channel. The shifts that have occurred were influenced in part by the geologic structures, so that the new river occupies a relatively stable course and channel through the synclinal parts of the Pasco Basin.

Glacial floods could alter this course by lateral river erosion and/or sediment infilling of the channel by tributary streams during major ice dam flooding. A certain probability exists that the river could be superimposed over the repository site. Subsequent local stream erosion could be substantially greater than general denudation especially if folding was occurring. 


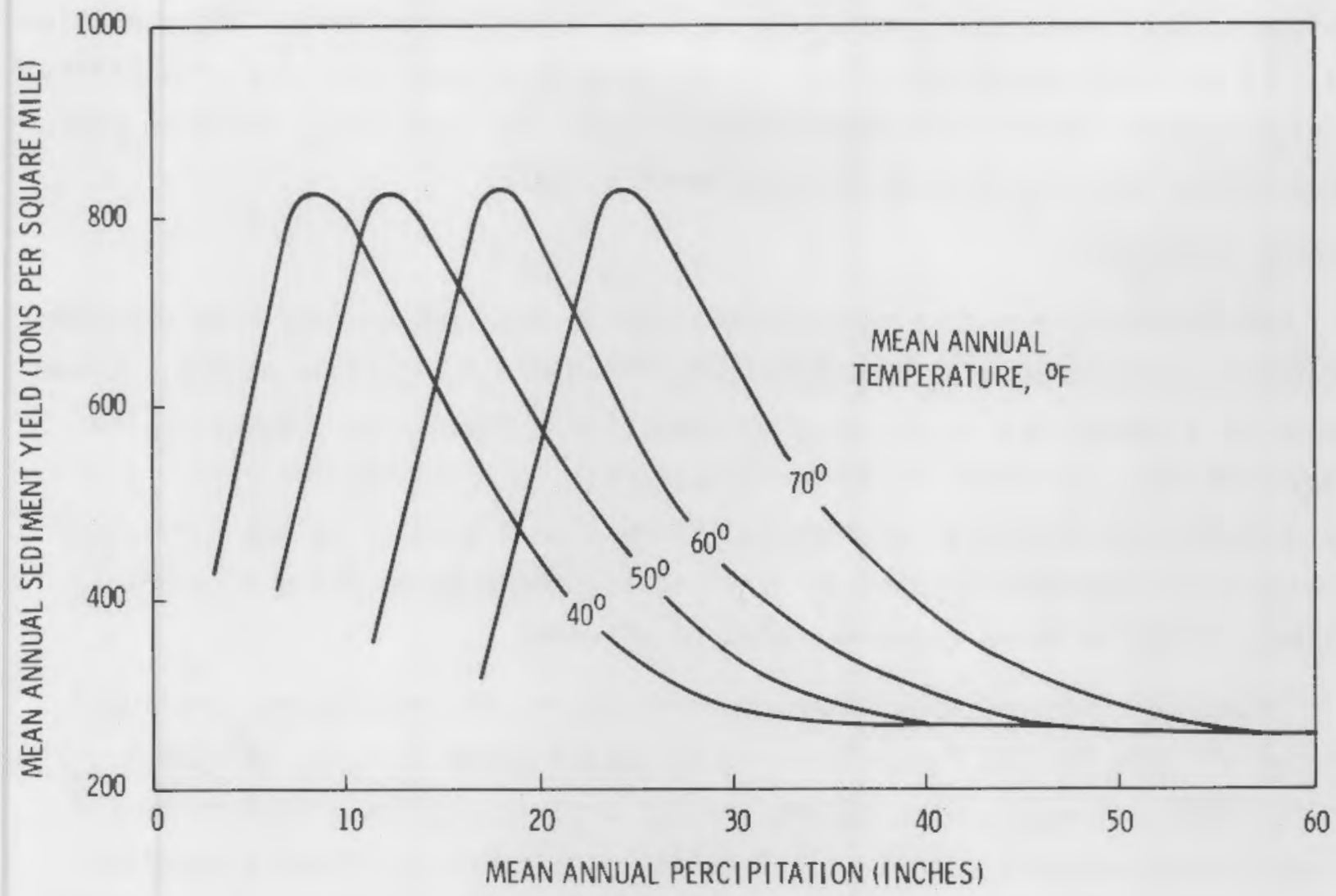

FIGURE 31. Climate and Sediment Yield (adapted from Schumm, 1965)

It is conceivable for the main stream of the Columbia River to be temporarily blocked by a landslide, glacial ice lobe, or volcanic material (e.g. lava flow). With the main stream temporarily blocked, flow down the coulees, the lower Snake River, and conceivably the Yakima River, could rapidly deposit sediments in the Columbia River channel. Such sediment buildup would reduce the channel gradient. The Columbia River would thus tend to dump its own sediment load once it encountered the reduced gradient. This could further enhance the channel infilling.

Similar infilling might result from the deposition of sediment during a Missoula-like flood. As the flood waters receded, the river might select a new course, probably in a more direct line from Sentinel Gap to Wallula Gap over a local floodplain. A presumed steep gradient over the basin fill materials might result in rapid headward erosion. The Columbia would then be 
incised into a new channe1, possibly over the buried repository. Major erosion would be stream downcutting as opposed to general denudation. The possibility of river channel alteration from blockage caused by landslides, volcanic extrusions and/or ice effects must be considered as well.

General Denudation

Denudation refers to a general lowering of the land surface from erosional processes and must be distinguished from stream or glacial downcutting. Exhumation of a repository is unlikely to result from denudation. However, the removal of tens of meters of surficial material is certainly possible. This could change the potential pathlength for nuclide migration by the removal of a relatively impermeable layer or by affecting recharge to the ground water system. Stream erosion rates may also be affected.

Using this present mean annual precipitation and temperature, the total denudation rate for the Pasco Basin is estimated to be $50 \mathrm{~m}$ per $10^{6}$ years (Tubbs 1979). However, some of the smaller drainage basins tributary to the Columbia River support higher relief ratios, consequently higher denudation rates are probable in these areas. A temperature decrease of $4-5^{\circ} \mathrm{C}$ accompanying a slight precipitation increase, might result in a denudation rate of $100 \mathrm{~m}$ per $10^{6}$ years (Tubbs 1979).

The rate of denudation is site dependent. Among other factors, it depends on climate, topography, material lithology, and to a major extent, human activity. Erosion rates can be increased by as much as an order of magnitude by injudicious farming (Judson 1968). Figure 32 and Table 18 indicate the effects of relief and runoff on general denudation. Figure 33 shows the current denudation rates in the Columbia River system relative to several other areas in the United States.

\section{Stream Erosion}

Average or general denudation rates do not reflect the much greater rates that are possible for local stream erosion. Gera and Jacobs (1972) used the Grand Canyon to illustrate this point. They conclude that the Grand Canyon, $350 \mathrm{~km}$ long and $1600 \mathrm{~m}$ maximum depth, was formed in 1.5 to 2 million years during the period the region was being uplifted to a height of 1800 to $2400 \mathrm{~m}$ 


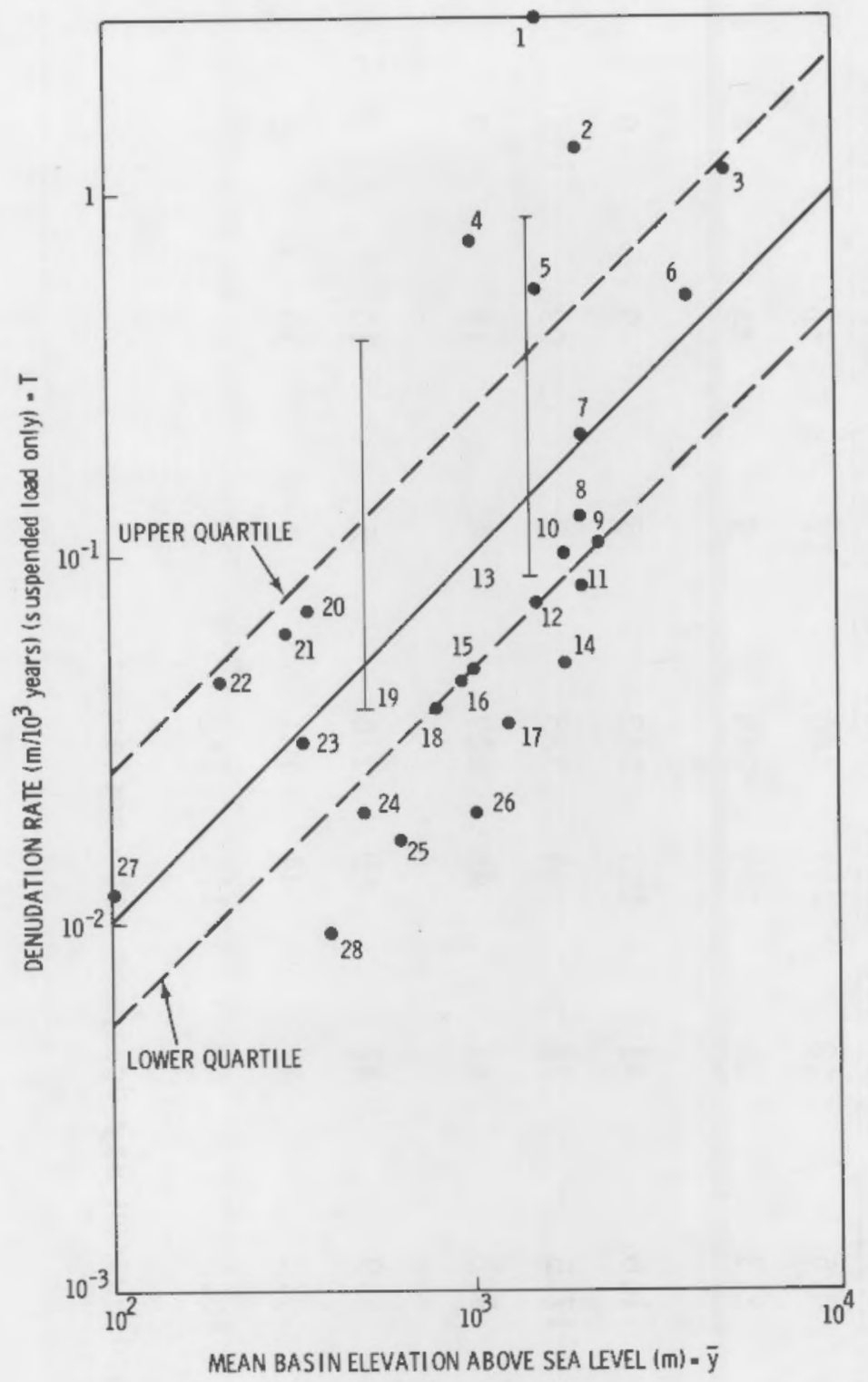

1. LO (CHINA)

2. YELLOW OR HWANG (CHINA)

3. KOSI (INDIA AND NEPAL)

4. GANGES (INDIA)

5. RED OR YUAN (NORTH VIETNAM AND CHINA)

6. BRAHMAPUTRA IEAST PAKISTAN AND (TIBET)

7. INDUS (WEST PAKISTAN)

8. YANGTSE (CHINA)

9. COLORADO (U.S.A.)

10. MEKONG (SOUTH EAST ASIA AND CHINA)

11. RIO GRANDE (U.S.A. AND MEXICO)

12. MISSOURI (U.S.A.)

13. SMALL BASINS IN EAST WYOMING (U.S.A.)

14. SALT (U.S.A.)
15. RED (U.S.A.)

16. MISSISSIPPI (U.S.A.)

17. CHEYENNE (U.S.A.)

18. TENNESSEE (U.S.A.)

19. SMALL BASINS IN OKLAHOMA AND TEXAS (U.S.A.)

20. ROANOKE, VIRGINIA (U.S.A.)

21. SANTEE, NORTH CAROLINA (U.S.A.)

22. SAVANNAH, GEORGIA (U.S.A.)

23. AMAZON (SOUTH AMERICA)

24. NILE (NORTH $E A S T$ AFRICA)

25. SUSQUEHANNA, PENNSY V VANIA (U.S.A.)

26. BRAZOS, TEXAS (U.S.A.)

27. PEARL, MISSISSIPPI (U.S.A.)

28. POTOMAC, VIRGINIA AND MARYLAND (U.S.A.)

FIGURE 32. Suspended Solids Denudation Rate as a Function of Elevation (adapted from Carson and Kirkby 1972) 
TABLE 18. Rates of Regional Erosion in the United States (modified from Judson and Ritter 1964, Gera and Jacobs 1972)

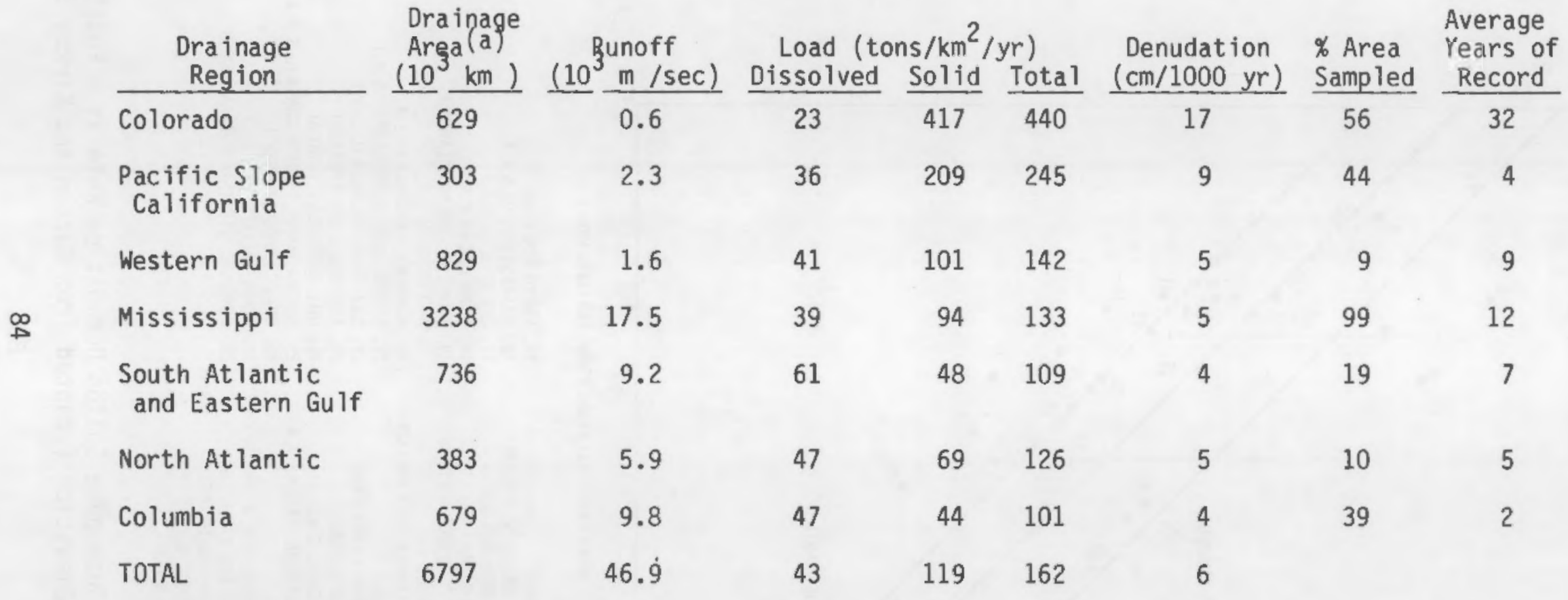

(a) Great Basin, St. Lawrence, and Hudson Bay drainage not considered. 


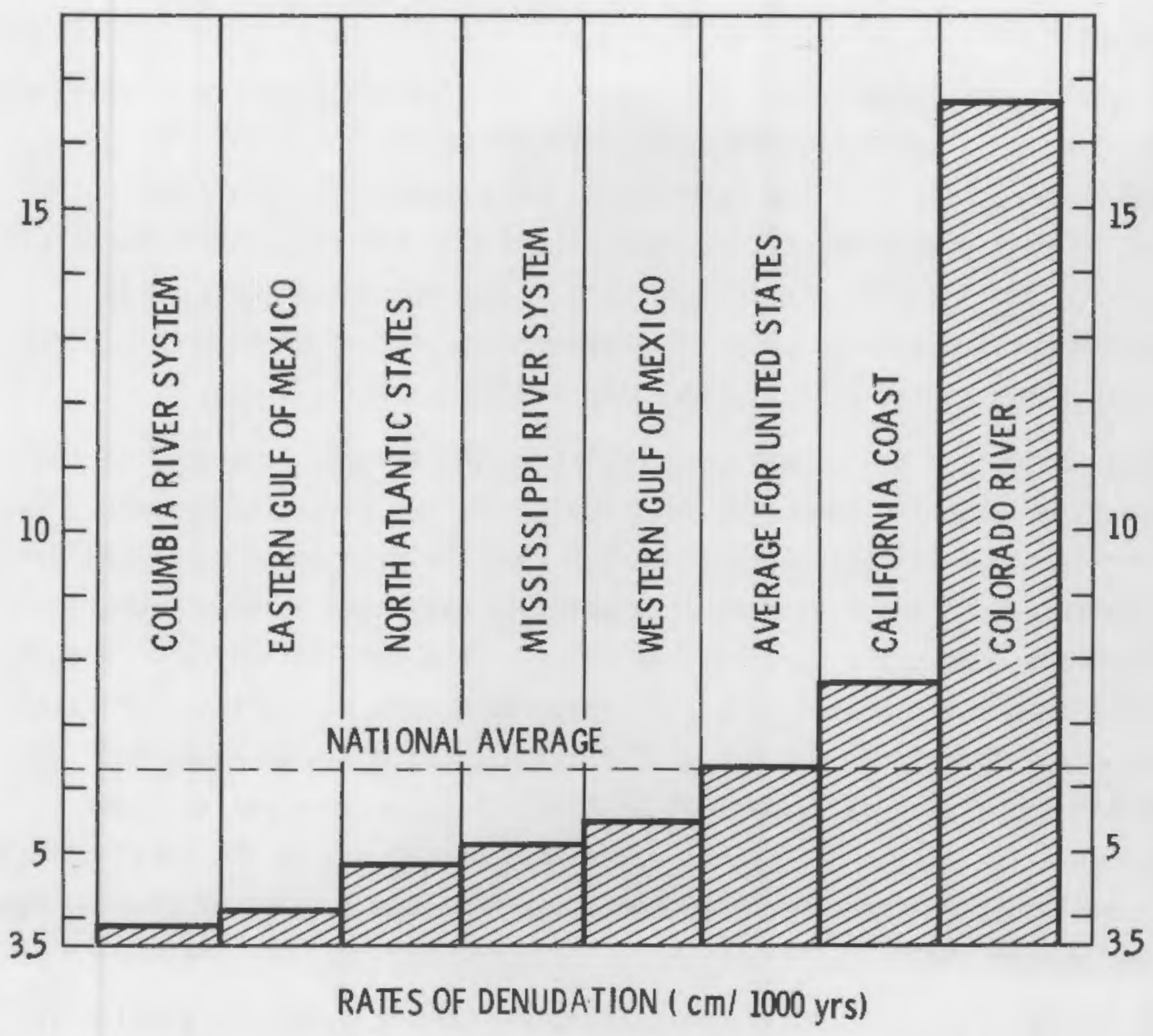

FIGURE 33. Rates of Denudation

above sea level. These estimates result in a stream erosion rate of $800 \mathrm{~m}$ $10^{6}$ years, 5 times higher than the regional denudation rate $(160 \mathrm{~m}$ $10^{6}$ years). This is not a unique case. Many valleys show evidence of changes in flood level in Quaternary times of tens to hundreds of meters (Fournier 1960, Holeman 1968).

For the Pasco Basin, average stream erosion rates do not vary significantly from the general denudation rates. One exception is that greater stream erosion rates can be expected if the area in question is a growing anticline cut by the Columbia River or one of its tributaries. If the river were to alter its course such that it was superimposed over a growing anticline, the erosion rates might be in the range of 300 to $500 \mathrm{~m}$ per $10^{6}$ year (Tubbs 1979). 


\section{Flood Erosion}

Presently, no estimate has been made of erosion associated with repeated ice-dam flooding. However, volumetric flows of up to $9.06 \times 10^{6} \mathrm{~m}^{3} \mathrm{~s}^{-1}$ are believed to be possible in the Pasco Basin for periods of a few days. Other flows up to this magnitude are also possible due to the release of ice margin lakes by ice dam failure. It is important to emphasize that erosion is extremely sensitive to flow rate. Therefore estimates of erosion should consider peak flows and as well as hydraulic damming at Wallula Gap.

Some attempt is being made at correlating the erosion potential of the Columbia River with its competent velocity during any given flood event. The competent velocity is considered to be 0.7 time the mean cross sectional velocity. The peak mean cross sectional velocity is estimated at four times the annual average mean cross sectional velocity. Thus far, estimates of erosion rates have been restricted to gravelly soils only, and no estimate for basalt is available. Therefore, the range of erosion rates given by Tubbs will be used initially. These rates suggest that uplift of an area has an order of magnitude greater effect on erosion rates than variations of the local climate. A similar finding has been reported for a larger class average of erosion rates (Gera and Jacobs 1972).

It is important to select a repository site where excessive erosion in the future is highly unlikely. The consequences associated with denudation or stream erosion are not limited to a reduction of overburden thickness and thus transport pathlength. Quite possibly the removal of a relatively impermeable layer could permit vertical recharge and new groundwater circulation pattern development which may have an adverse affect on the hydrologic conditions of a repository site.

\section{Wind Erosion}

Although under present conditions surficial wind erosion on the Columbia Plateau can be on the order of $1.0 \mathrm{~cm} \mathrm{yr}^{-1}$ locally, armoring and depression refilling is such that this erosion mechanism can only be sustained locally for an extremely short time. 
Summary

In summary, river flow is modeled as a superposition of variables such as precipitation over the watershed, average ice melt runoff, and catastrophic dam collapse. Flow through the hydraulic constriction at Wallula Gap and the inlet flow to the basin determine the river/lake conditions within the Pasco-Basin. Erosion is associated with a high energy river environment. The lake environment affects sedimentation and vertical recharge to the unconfined zone. River course alteration is a possibility, especially if the main stream of the Columbia River were to be blocked temporarily upstream from the basin. Denudation and selective stream erosion rates are given as averages. However, some attempt is being made to correlate erosion with peak river flows and material properties. The fundamental variables affected by this submodel are pathlength, effective stress, and shallow aquifer potentials. Figure 34 presents a logic flow for this submodel. Table 19 lists data requirements and data availability.

\section{DEFORMATION}

In this report, a fracture system is defined as a series of interconnected cracks that may support a permeability differing from that of intact rock. Dilational and/or shear displacements are considered. The following categories are covered: 1) undetected and/or accelerated deformation of the basalts, 2) faulting in the sub-basalt basement, 3) surficial fissuring caused by material loading or unloading, 4) impact fracturing, and 5) hydraulic fracturing. Deformation can affect all of the fundamental variables (pathlengths, conductivities, fluid potentials, and effective stresses) and, therefore, this is considered an extremely important submodel. However, the following paragraphs are to serve only as an example of how a submodel on deformation might be ultimately constructed. It must be recognized that as new theories are proposed and the geological and geophysical characteristics of an area such as the Columbia Plateau are better identified, the components of the various submodels presented herein must be similarly updated. 


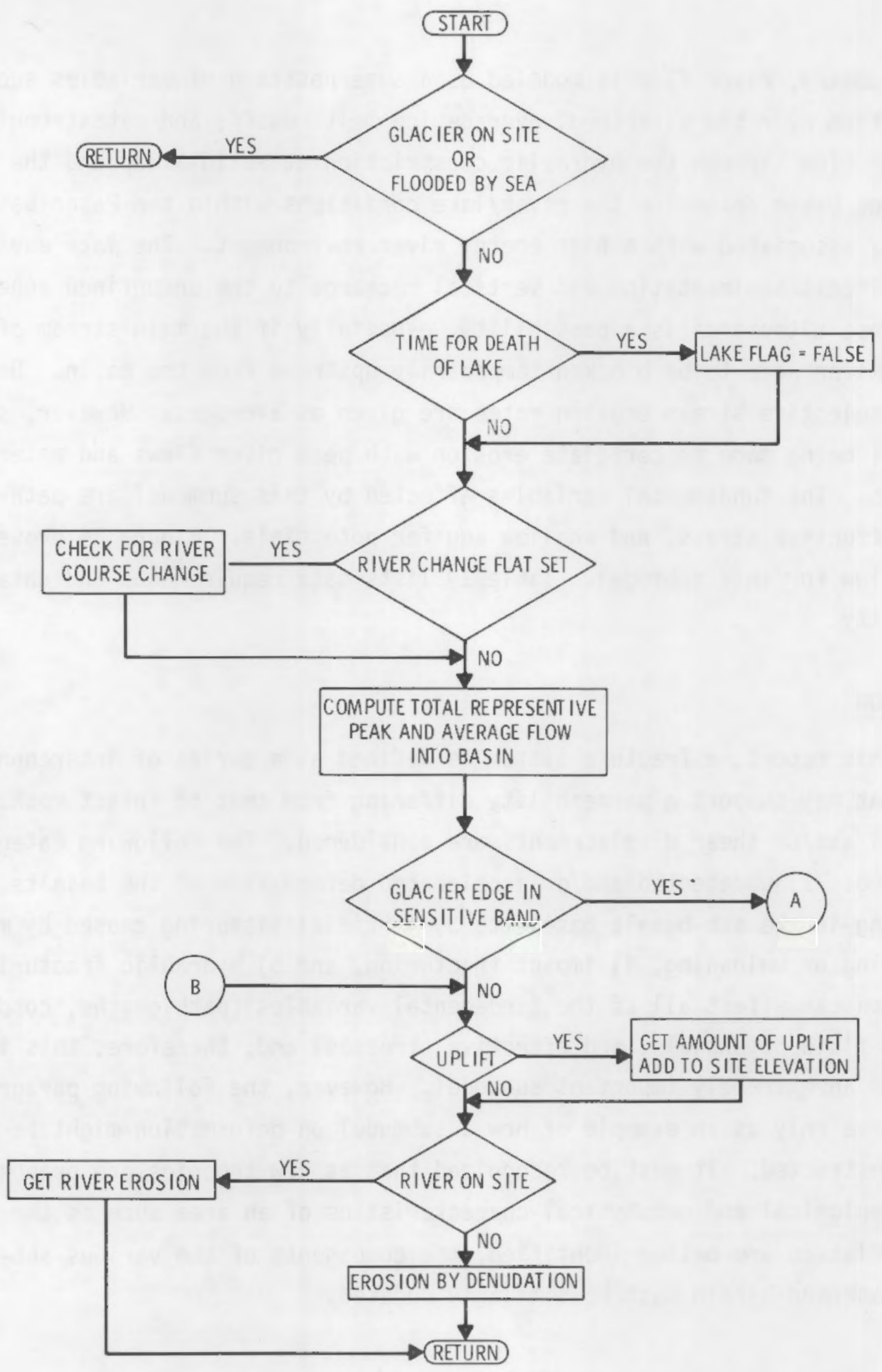

FIGURE 34. Logic Flow Diagram for Geomorphic Events Submodel 


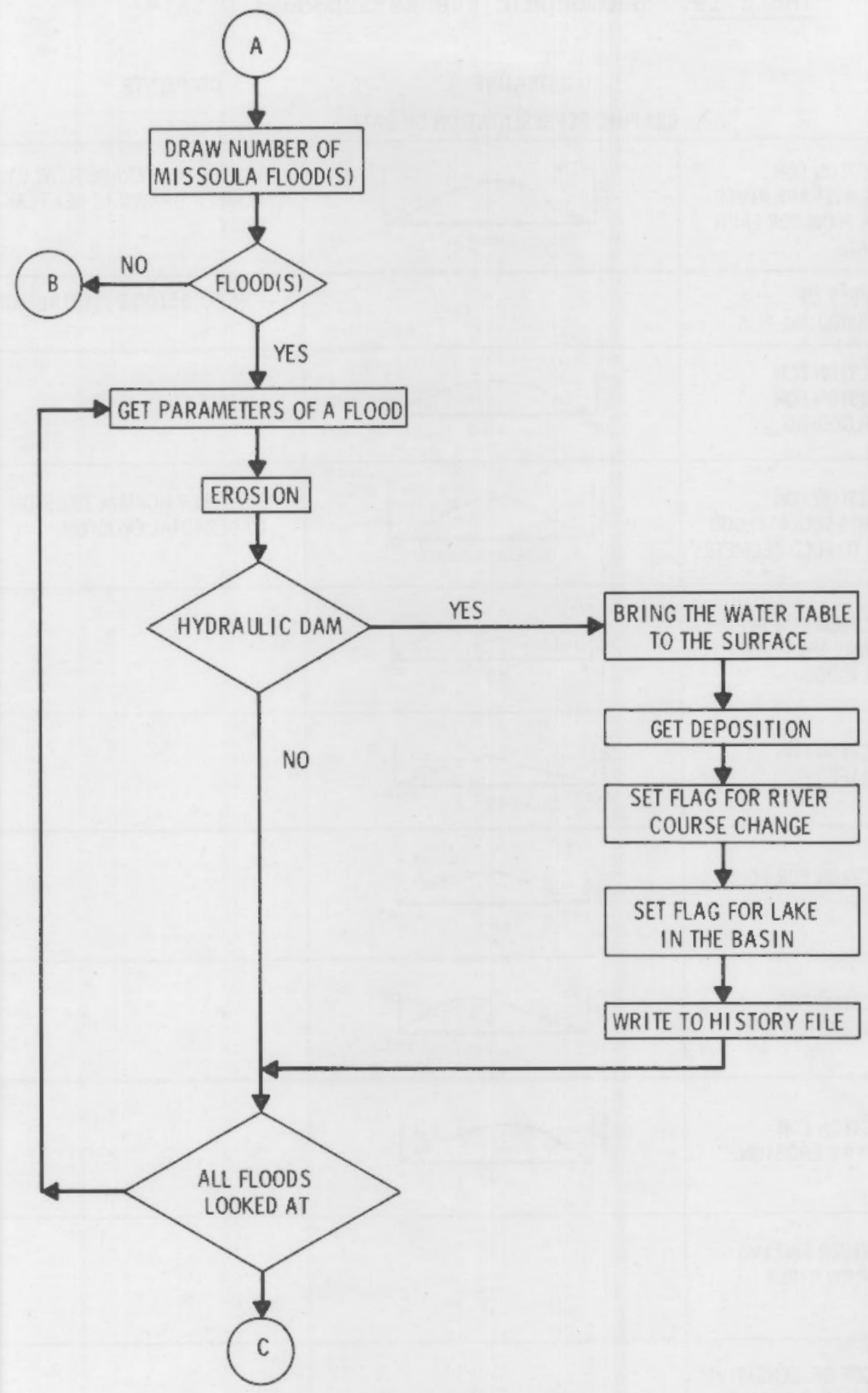

FIGURE 34 . (contd) 


\section{TABLE 19. Geomorphic Events Submodel Data(a)}

SUBJECT

ILLUSTRATIVE

COMMENTS

GRAPHIC REPRESENTATION OR DATA

\begin{tabular}{|c|c|c|}
\hline $\begin{array}{l}\text { DENSITY FUNCTION FOR } \\
\text { TRANSLATING AVERAGE RIVER } \\
\text { FLOW TO PEAK FLOW FOR EACH } \\
\text { CLIMATIC STATE }\end{array}$ & $\sum_{\text {Facton }}^{\frac{5}{0.0}}$ & $\begin{array}{l}\text { MULTIPLY AVERAGE FLOW BY } \\
\text { NUMBER DRAWN TO GET PEAK } \\
\text { FLOW }\end{array}$ \\
\hline $\begin{array}{l}\text { AVERAGE NUMBER OF } \\
\text { 'MISSOULA' FLOODING }\end{array}$ & & FOR POISSION DISTRIBUTION \\
\hline $\begin{array}{l}\text { DENSITY FUNCTION FOR } \\
\text { 'NORMAL' EROSION FOR } \\
\text { 'MISSOULA' PLOODING }\end{array}$ & $\sum_{m \times n-1}$ & \\
\hline $\begin{array}{l}\text { DENSITY FUNCTION FOR } \\
\text { INCREASED 'MISSOULA' FLOOD } \\
\text { EROSION DUE TO FOLD GEOMETRY }\end{array}$ & $\underbrace{}_{\text {mitrimicarion inction }}$ & $\begin{array}{l}\text { MULTIPLY NORMAL EROSION } \\
\text { TO GET TOTAL EROSION }\end{array}$ \\
\hline $\begin{array}{l}\text { DENSITY FUNCTION FOR DEPO- } \\
\text { SITION DURING LAKE FORMATION } \\
\text { OF MISSOULA FLOOD }\end{array}$ & $\sum_{w^{4}}$ & \\
\hline $\begin{array}{l}\text { DENSITY FUNCTION FOR } \\
\text { REGIONAL UPLIFT }\end{array}$ & 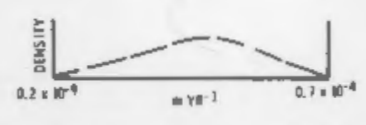 & \\
\hline $\begin{array}{l}\text { DENSITY FUNCTION FOR FOLD } \\
\text { GROWTH RATES }\end{array}$ & $\underset{0,2 \times w^{3}}{m \times e^{-2}}$ & \\
\hline $\begin{array}{l}\text { DENSITY FUNCTION FOR } \\
\text { 'NORMAL' DENUDATION RATE }\end{array}$ & 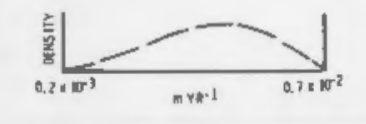 & \\
\hline $\begin{array}{l}\text { DENSITY FUNCTION FOR } \\
\text { 'NORMAL' STREAM EROSION } \\
\text { RATE }\end{array}$ & $\underset{0.2 \times 104}{-\infty}$ & \\
\hline $\begin{array}{l}\text { CHANCE FOR RIVER FALLING } \\
\text { ON THE SITE WHEN RIVER } \\
\text { MOVES }\end{array}$ & & . \\
\hline $\begin{array}{l}\text { UPPER LATITUDE OF 'SENSITIVE' } \\
\text { AREA FOR GLACIER FLOODING }\end{array}$ & & \\
\hline $\begin{array}{l}\text { LOWER LATITUDE OF 'SENSITIVE' } \\
\text { AREA FOR GLACIAL FLOODING }\end{array}$ & & \\
\hline & CONTINUED ON NEXT PAGE & \\
\hline
\end{tabular}

(a) Data is under development and is not available at this time 
TABLE 19. (contd)

SUBJECT

ILLUSTRATIVE

COMMENTS

GRAPHICAL REPRESENTATION OR DATA

\begin{tabular}{l|l|l}
\hline MAXIMUM FLOW AT & \\
WALLULA GAP WITHOUT & & \\
HYDRAULIC DAM FORMING & & \\
\hline CORRECTION FACTOR FOR & & \\
'NORMAL' STREAM EROSION & & \\
FOR EACH ROCK TYPE & & \\
\hline CORRECTION FACTORS FOR & & \\
'NORMAL' STREAM EROSION & & \\
FOR EACH CLIMATE STATE & & \\
\hline CORRECTION FACTOR FOR & & \\
'NORMAL' DENUDATION & & \\
EROSION FOR EACH ROCK TYPE & & \\
\hline CORRECTION FACTORS FOR & & \\
'NORMAL' DENUDATION & & \\
EROSION FOR EACH CLIMATE & & \\
STATE & & \\
\hline
\end{tabular}

Undetected and/or Accelerated Deformation of the Basalts

The possibility of an undetected deformational feature existing at some distance from the repository, must be considered in a release scenario analysis. The cumulative probability of such a feature probably increases and the consequences decrease as a function of distance from the repository. Therefore, an estimation of the probability of undetected features occurring within an appropriate distance from the repository site is recommended. Such features might be: 1) anticlines with or without associated faults, 2) synclines, and 3) faults in the sub-basalt basement.

One example approach to undetected feature probability estimation is to infer a geologic slip rate and cumulative deformation in an area from recorded microseismic data. It is assumed that the state of stress and the average strain rate for the region in question have remained relatively constant during the last few million years (Coombs 1979). Thus the amount of inferred deformation might be compared to the amount of observable deformation. The difference would be a gross estimate of undetected deformation. Such analys is 
is based on the percentage of recorded seismicity that can be attributed to known features. The remainder is considered to be associated with undetected features.

Regional compressive stresses in the Columbia Plateau region have resulted in the anticlinal deformation of the basalt flows in many locations. Most of the major visible anticlines vary from 75 to $150 \mathrm{~km}$ in length, average about $2 \mathrm{~km}$ in width, and generally trend $\mathrm{N} 55 \mathrm{~W}$ to east-west. It has been suggested that for a layered system (e.g., the Columbia Plateau basalt flows) the wave legnth of folding might be inversely proportional to the thickness of the layered sequence in the given area (Biot 1965). Beyond some magnitude of deformation, stresses may no longer be effectively relieved by folding. In the Columbia Plateau the subsequent result might be thrust or reverse dip-slip faulting, often along east-west oriented zones or planes of weakness. Some or all of the fault displacement may possibly be accomodated within pre-existing jointing or other planes of weakness associated with the basalt flows. Such shearing within the joints may account in part for the temporal and spacial clustering of microearthquakes observed in the area (Rothe 1978). It may be conceivable, therefore, to correlate microseismicity with folding and faulting in the Columbia Plateau Region. If so, such correlations might assist other geological and geophysical studies in the identification of undetected folds and faults which are masked by the upper stratigraphic units.

Many examples can be found of large discrepancies between geological reconnaissance and microseismic data, especially in areas of low to moderate seismic activity. Wight (1979) cites the Flathead Lake area of Montana, where less than $20 \%$ of the activity could be attributed to mapped faults, and the state of Washington, where perhaps less than $10 \%$ of the recorded seismicity can be associatd with known features. A plot of seismicity in Washington is shown in Figure 35. Naturally the data reflects a certain bias towards areas that have been instrumented for seismicity in the recent past.

For a central eastern Washington area of $10^{5} \mathrm{~km}^{2}$, Wight generated a recurrence relationship between seismicity and geologic slip rate and compared the result with the average strain rate for the region. The regional strain 


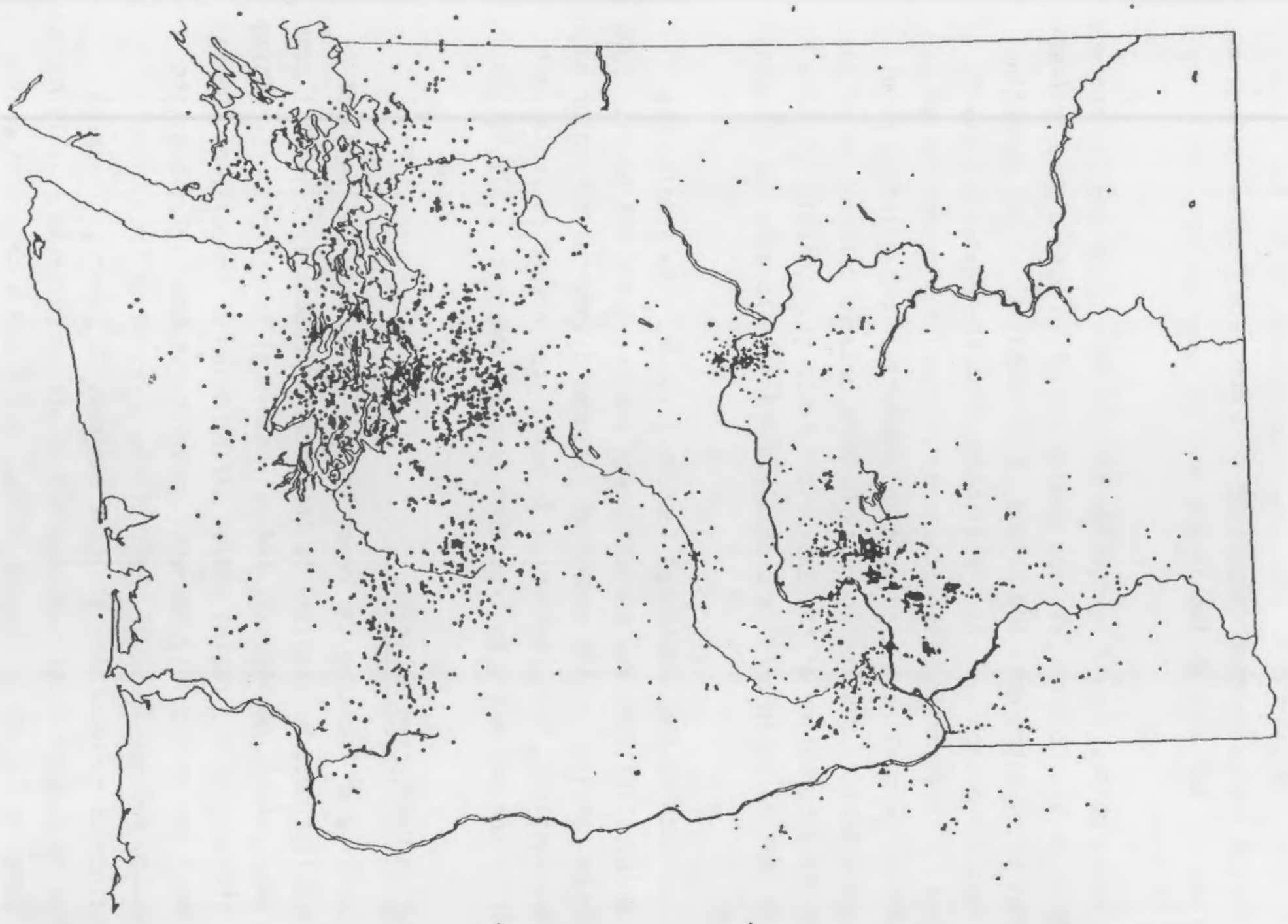

FIGURE 35. Earthquake Epicenters from the West (circle) and Eastern (triangles) Washington Data Files (Bishop 1978) 
rate estimated from anticlinal deformation is approximately $3 \mathrm{~km}$ per $4 \times 10^{6}$ years (Coombs 1979). Wight (1979) concludes that in this region the probability of a strain energy release comparable to a moderately-sized earthquake occurring in any $10^{2} \mathrm{~km}^{2}$ area during in the next $10^{6}$ years (Wight 1979) is $10^{-6} \mathrm{yr}^{-1}$ or less.

The following points should be considered: 1) Ongoing geological and geophysical studies on the Columbia Plateau should result in more of the deformational features being discovered and mapped, 2) Probability of not detecting the feature should approach zero as the distance from the repository cavity approaches zero, 3) Deformation (strain energy release) may be manifested as folding, faulting, or small scale shear displacements of pre-existing joint features. Furthermore, a distinction must be made between deformation of the basalt layers and deformation of the sub-basalt basement. Seismicity below 8-10 $\mathrm{km}$ in the central basin area is probably due solely to deep seated basement features.

Another approach to the undetected feature problem is to examine the record of site investigations for nuclear power plants, dams, and mines. Some statistics can be compiled on the number of features discovered during or subsequent to construction. This work which is being spearheaded by Professor Baecher of MIT is not currently incorporated into the Repository Simulation mode 1 .

Probability of an Undetected Anticline

The probability of locating the repository within a given distance of an undetected anticline must be supplied to the model. Presumably this will come from refined geophysical, geological, and seismological investigations. Changing tectonic stresses in the region and/or perturbation of the average strain rate would affect the probability numbers. However, Coombs (1979) suggests that the direction and magnitude of the tectonic stresses on the Columbia Plateau should remain constant for at least the next $10^{6}$ years. The area should continue to support a maximum compressive stress oriented roughly northsouth, as is shown in Figure 36 (Coombs 1979). The minimum compressive axis is generally considered to be within 45 degrees of vertical. 


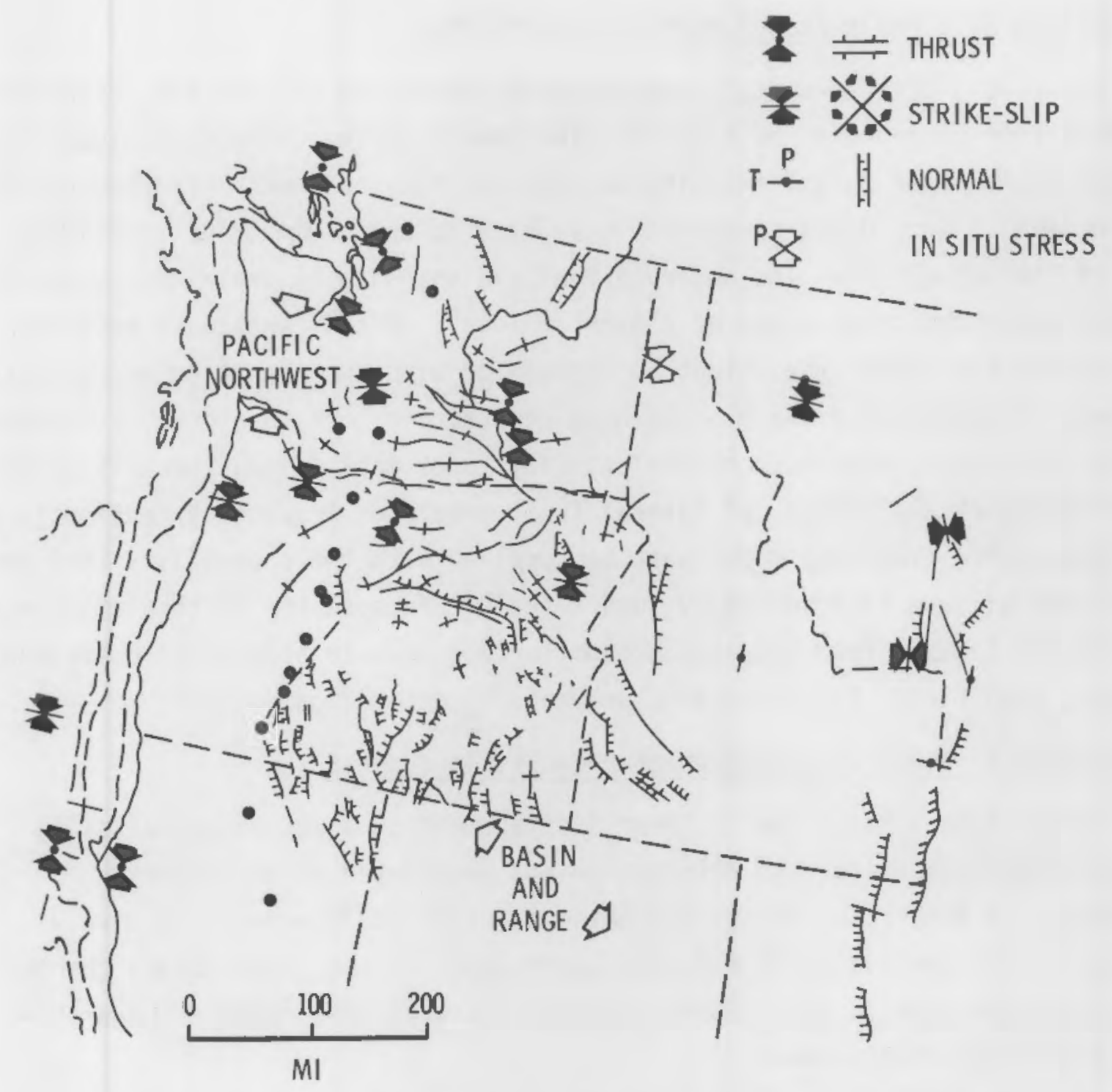

FIGURE 36. Stress Orientation for Pacific Northwest and Bas in Range Provinces (Coombs 1979)

\section{Strain Rate}

Conceivably the strain rate could change even if the tectonic stress state remained constant. Therefore, a range of possible changes along with estimated probabilities must be supplied to the model. As yet, no such data have been generated so a normal Poisson distribution centered on $0.75 \mathrm{~mm} / \mathrm{yr}^{-1}$ is being assumed for the region. 
Probability of a Fault Associated with the Folding

Apparently after a certain magnitude of anticlinal deformation, stresses can no longer be relieved by folding. The result in the Columbia Plateau is reverse dip-slip or thrust faulting on approximately east-west oriented planes (Rothe 1978). Such displacement may give rise to the asymmetrical configuration of the anticlines. The observed faults might also be explained as gravity sliding along the steep slope of a tight fold. (a) Micro-earthquake activity, possibly of the swarm type, might be associated with such faulting and gravity sliding. Although some swarm areas have been active more than once, a tendency exists for lateral migration of the activity, presumably along the axis of the fold (Malone et al. 1976). If lateral fault growth or fracture extension is a real phenomenon, then the model must be supplied with the probability that the repository will be intersected by such a fault. Because the microseismic swarm activity is located from near the ground surface down to about 4 to $6 \mathrm{~km}$, depth is not a significant factor in this probability estimation.

Probability of Shear Displacement on Pre-Existing Joints

Rather than a major fault, shear displacement on a set of pre-existing joints might account for the deformation and associated seismic energy releases. In this case, the blocks between joints would remain relatively unaltered, but the hydraulic flow characteristics of the joints might change. The closer the site is to a known anticlinal feature, the greater the probability of joint displacement.

Rothe (1978) shows that on the average, earthquakes swarms exhibit a 4-5 $\mathrm{km}^{2}$ spatial extent, but a $10 \mathrm{~km}^{2}$ sensitivity zone is more conservative. Based on these data, and the fact that the observable anticlines are $2 \mathrm{~km}$ wide on the average and range from about 5 to $20 \mathrm{~km}$ apart, it may be possible to estimate probabilities of shear displacement on pre-existing joints based on the distance from the undetected feature.

(a) This information is based on work done by Davis which is reported in part in this document. A sunmary of Davis' research has been published (Davis 1979). 


\section{Associated Permeability Increases}

The probability of a fault intersecting the repository is related to the distance from a known anticline, the estimated distance for a hypothesized undetected anticline, and the density of known faults in the area, as shown in Figure 37. Regardless of whether a fault or a zone of shear planes is being hypothesized as a release scenario, the result is characterized as: 1) alterations in hydraulic conductivity, and 2) alterations in fluid potentials along the path.

In many areas where the basalts have undergone anticlinal deformation, the joints were found to be altered by ground water and in some cases slicken-sided (Rothe 1978). This implies that for at least a period of time following the opening of the joints, water may be vertically mobile through all or part of a basalt flow, and horizontally mobile in the vesicular flow tops. Such vertical water mobility might in part explain the lateral and vertical migration of seismic activity associated with earthquake swarms. The presence of water might reduce the effective stress on any potential shear plane and hence allow further displacement at a lower level of shear stress.

The probability and hydrogeologic effect of faulting varies with the nature of the faulting process. The fault type depends on the state of effective stress and the mechanical characteristics of the material being faulted. Effective stress depends on the tectonic stresses, lithostatic or overburden stresses, and interstitial fluid pressures.

Faulting in alluvial aquifers commonly reduces the horizontal permeability of aquifers by producing gouge, localizing cementation by secondary minerals, reorienting flat clasts with their long axis parallel with the fault plane, and probably most important, by offsetting permeable beds so that they are set against nonpermeable zones.(a)

Faulting in brittle rocks may increase local permeabilities by several orders of magnitude. Inflows of large volumes of water into mines and tunnels

(a) This information is based on work done by Davis which is reported in part in this document. A summary of Davis' research has been published (Davis 1979). 


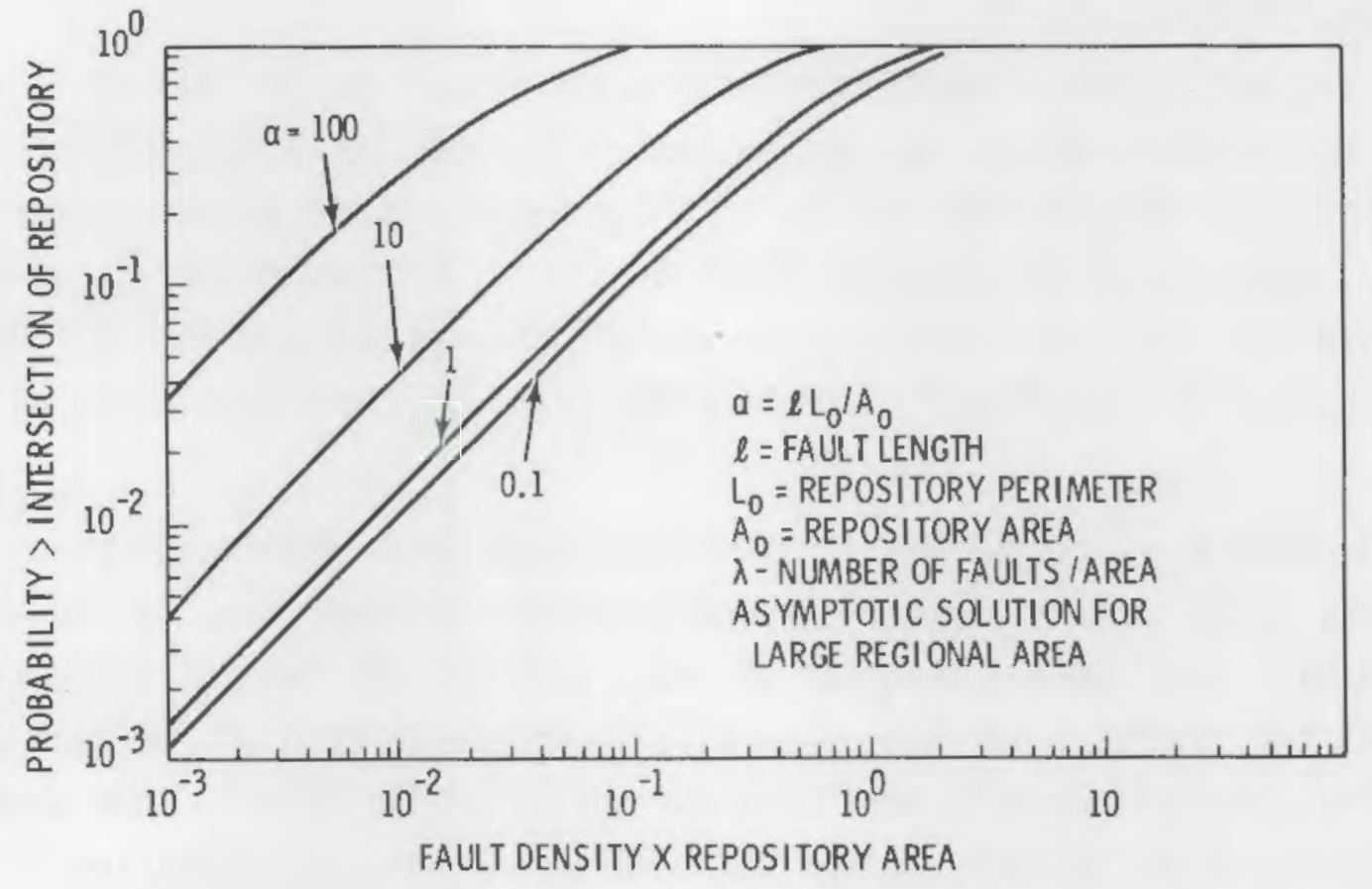

FIGURE 37. Fault Intersection Probabilities (Little 1978)

along fault zones are widely reported in the literature. However, unless these fracture pathways are connected to aquifer, continued water flow is unlikely. The water storage capacity of the low porosity rocks is usually less than $5 \%$ of the ir total volume. (a)

Existing faults in the Columbia Plateau region need to be investigated, and groundwater flow characteristics determined. A distribution of known or inferred fault lengths and widths would also be beneficial. For example, Bond (1978) reports that a fault zone associated with Rattlesnake Mountain may be less than $100 \mathrm{~m}$ wide. Faults lengths on the Columbia Plateau on the order of 40-50 km have been observed or inferred (Brown 1978).

Estimating the limits of bulk permeabilities for a fault or joint deformation scenario is a difficult task, at best. One example approach is to use a parallel plate model similar to that described by Brace (1978). Figure 38 presents the model. For basait, the principal joints or fractures are presumably

(a) This information is based on work done by Davis which is reported in part in this document. A summary of Davis' research has been published (Davis 1979). 


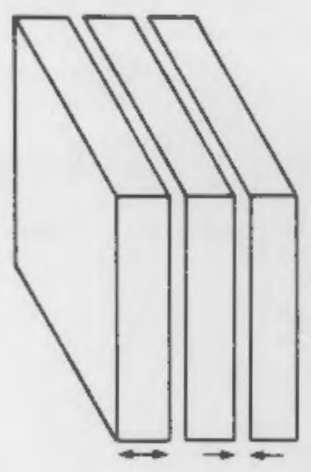

$$
\begin{aligned}
& S=\text { JOINT SPACING }=1 \mathrm{~m} \\
& W=\text { APERTURE WIDTH }=100 \times 10^{-6} \mathrm{~m} \\
& K=\text { PERMEABILITY } \quad W^{3} / 12 \mathrm{~S} \quad 10^{-13} \mathrm{~m}^{2} \quad 100 \mathrm{md}
\end{aligned}
$$

\section{FIGURE 38. Parallel Plate Fracture Model (Brace 1978)}

oriented vertically in the colonnade and entablature, and random throughout the remainder of the flow. The primary parameters are then joint spacing and aperture width. The empirically derived relationship presented by Brace is as follows:

$$
k=w^{3} / 12 s
$$

where:

$$
\begin{aligned}
& k=\text { permeability }\left(m^{2}\right) \\
& w=\text { aperture width }(m) \\
& s=\text { joint spacing }(m)
\end{aligned}
$$

Table 20 and Figure 39 present some estimated permeabilities based on this relationship and some illustrative parameter values.

Rothe (1978) speculates that at depth the thinner basalt flows $(\leq 30 \mathrm{~m})$ apparently have, on the average, joint spacings of $1.0 \mathrm{~m}$. Thicker flows $(50-100 \mathrm{~m})$ tend to spacings of about $10.0 \mathrm{~m}$. Outcrops reveal a much greater density of smaller fractures; however, these features may be due to the relaxation of confining stresses by unloading or deformation. Characterization of the fracture densities, aperture widths, secondary mineral deposits, and bulk hydraulic conductivities should be given high priority in future field investigations. Data are especially required for temperature and stress conditions 
TABLE 20. Example Bulk Permeabilities for a Joint Rock Calculated From Parallel Plate Theory

\begin{tabular}{|c|c|c|c|c|}
\hline $\begin{array}{c}\text { Joint Spacing } \\
(\mathrm{m})\end{array}$ & $\begin{array}{c}\text { Aperture width } \\
(\mathrm{mm})\end{array}$ & $\begin{array}{c}\text { Permeahility } \\
\left(\mathrm{m}^{2}\right)\end{array}$ & $\begin{array}{c}\text { Permeability } \\
\text { (md) }\end{array}$ & $\begin{array}{l}\text { Hydraulic } \\
\text { Conductivjty } \\
\text { (cm sec }\end{array}$ \\
\hline 0.1 & $10^{-1}$ & $10^{-1 \overline{2}}$ & $10^{2}$ & $10^{-4}$ \\
\hline 0.1 & $10^{-2}$ & $10^{-15}$ & $10^{-1}$ & $10^{-7}$ \\
\hline 1.0 & $10^{-1}$ & $10^{-13}$ & $10^{1}$ & $10^{-5}$ \\
\hline 1.0 & $10^{-2}$ & $10^{-16}$ & $10^{-2}$ & $10^{-8}$ \\
\hline 10.0 & $10^{-1}$ & $10^{-14}$ & 10 & $10^{-6}$ \\
\hline 10.0 & $10^{-2}$ & $10^{-17}$ & $10^{-3}$ & $10^{-9}$ \\
\hline 10.0 & 10 & $10^{-11}$ & $10^{3}$ & $10^{-3}$ \\
\hline
\end{tabular}

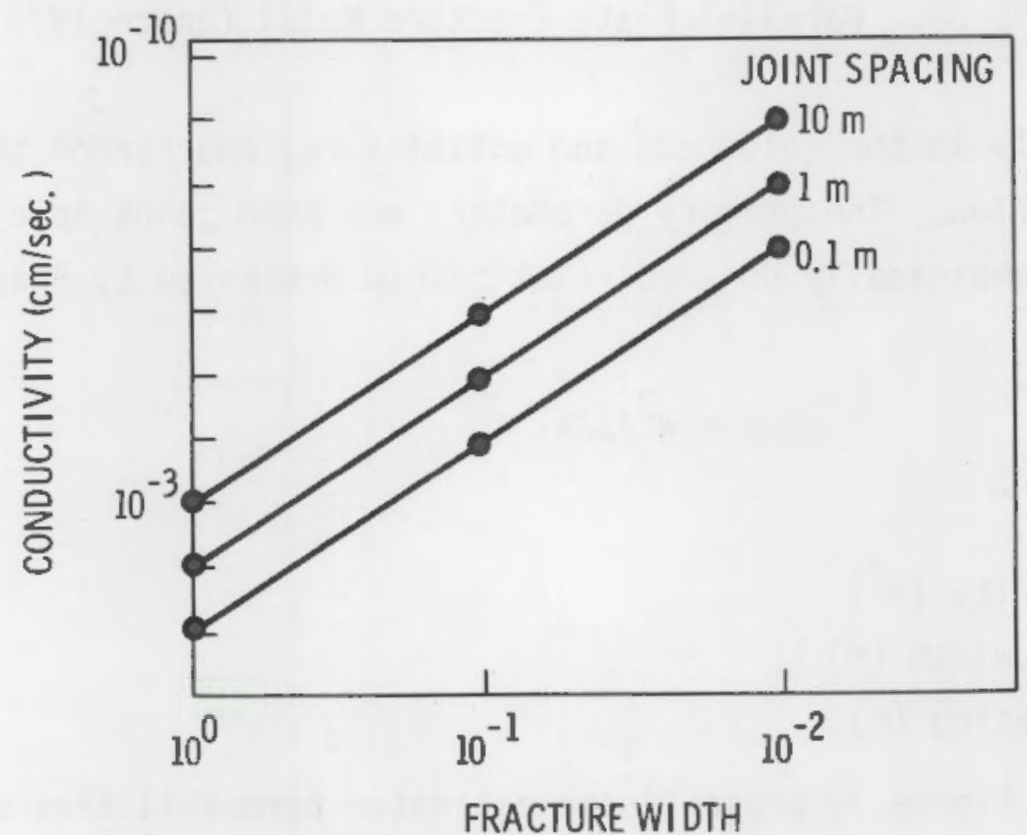

FIGURE 39. Conductivity vs. Fracture Width for Various Joint Spacing 
that might be expected at the depth of the repository. Joints and fractures are not always parallel and continuous features, and therefore water flow, if any, may be along a very tortuous path. Consequently bulk hydraulic conductivities should be determined from field data if possible rather than by Brace's (1978) empirical relationship.

Note that in this Repository Simulation model, a breach of the repository requires creation of a continuous path that connects fluid sources with different fluid potentials or dynamic heads. Both a pathway and a fluid potential difference must be present for water flow through the repository. Also of importance is the effect differential fluid potentials may have on the lateral flow in interconnected but separate flow zones.

Development of the pathway and changes in the head differential need not occur simultaneously. Pressurized recharge of an aquifer from glacial loading may change the fluid potentials tens of thousands of years after the interconnecting path has been created by shear deformation of the joints. Therefore, a distribution of possible fracture healing rates may need to be supplied. Such healing or permeability degradation might be caused by secondary mineralization and/or creep closure in response to the confining stress at depth. Bookkeeping of such time dependent information is the primary mission of the layered earth model (LEM) part of the Repository Simulation model.

Faulting in the Sub-basalt Basement

Although the thick sequence of basalts obscures the basement, the type and magnitude of basalt deformation indicates the possibility of glide motion at depth (McKee 1972). Until the distribution of deep faults (if any) can be mapped, a random distribution of basement faulting must be assumed. Geologic slip rate may possibly be inferred from deep seismicity. In this manner the probability of an rupture on undetected basement fault within a $100 \mathrm{~km}^{2}$ area around the repository may be estimated.

It is unlikely that a fault in the slib-basalt basement, which has not moved since the basalt layer hosting the repository was formed ( 8 to 14 million years ago), will rupture through the repository in the next $10^{6}$ years. Therefore, the assumption has been made that if no fault is detected during the 
construction of the repository, no fault exists at depth directly below the repository. Angular or lateral extension of a neighboring deep fault intersecting the repository area is also considered unlikely.

It is possible, however, that an undetected fault runs adjacent to the repository but not through it. Subsequent displacement on the fault might then trigger displacement on the joint features intersecting the repository. Thus, the deep seated undetected fault might replace the basalt anticline as the mechanism for inducing shear displacement of joints.

Wight indicates that offset displacement associated with a single earthquake in the Pasco Basin might be in the range of 0.1 to 1.0 meters. Offset on the secondary path (joints) is assumed to be about a few centimeters at most. Once shearing along a joint has occurred, subsequent offset may be possible at lower stress levels. As a consequence, deep-seated fault rupture may facilitate future deformation or strain release in the affected basalt layers. Vibratory Excitation and Backfill Material Response

The effect of seismic energy propagation (earthquakes) and the potential impact on a repository buried 300 meters or deeper in the basalt must also be analyzed. Vibratory excitation apparently represents a negligible hazard to a backfilled repository, provided the backfill has been properly designed and engineered (Wight 1979). A recent study for underground reactors suggests that the ground motion at depth in an undisturbed medium can be one-half to two-thirds of the ground motion experienced at the ground surface (Wight 1979). Therefore, the backfill must be engineered in such a way that the material acoustic impedances are closely matched. To do this, seismic design criteria for the backfill are required.

Depending principally on the distance and magnitude of the earthquake, ground motion excitation in the Columbia Plateau region might be expected to encompass accelerations in excess of $1 \mathrm{~g}$, velocities greater than $20 \mathrm{~cm} \mathrm{sec}^{-1}$, frequencies up to at least $50 \mathrm{~Hz}$, and total duration of the excitation exceeding 40 seconds sometime in the next $10^{6}$ years (Wight 1979). Table 21 shows 
TABLE 21. Reported Seismic Events (M $\geq 5.5$ ) Near Hanford Since 1872

\begin{tabular}{|c|c|c|c|c|c|}
\hline Location & Date & M & $I_{\max }$ & $\begin{array}{l}\text { Distance } \\
\text { from } 200 \text { Area } \\
\end{array}$ & $\begin{array}{c}\text { Intensity } \\
\text { at } 200 \text { Area } \\
\end{array}$ \\
\hline US-Canada & $12 / 14 / 1872$ & 7.5 & 9 & $304 \mathrm{~km}$ & v \\
\hline Puget Sound & $4 / 13 / 49$ & 7.1 & 8 & 232 & $I-I V$ \\
\hline Puget Sound & $4 / 29 / 65$ & 6.9 & 8 & 223 & IV \\
\hline Milton-Freewater & $7 / 16 / 36$ & 5.8 & 7 & 122 & IV \\
\hline Puget Sound & $11 / 13 / 39$ & 5.8 & 7 & 267 & III \\
\hline Puget Sound & $4 / 29 / 45$ & 5.5 & 7 & 182 & I - IV \\
\hline Corfu & $11 / 1 / 18$ & - & 6(?) Prob. 4 & 14 & III - IV \\
\hline Cascades & $12 / 30 / 26$ & - & 6 & 54 & I -III \\
\hline
\end{tabular}

some of the historical seismicity reported for the Pasco Basin areas. The only large historical earthquakes that have occurred in the region were at distances greater than 200 kilometers from the Pasco Basin. The geologic evidence suggests that a few moderate to strong earthquakes have occured in the Pasco Basin. Using a fault-surface area relationship $(M=4.2+\log A)$ from Wight (1979), where $M$ is the Richter magnitude and $A$ is the rupture surface area of the fault, the potential earthquakes shown in Table 22 are predicted.

Depths of the faults are estimated from depths of microseismic events in the area. Fault length is measured at the surface. The product of fault length and fault depth (measured along the dip of the fault) is the fault surface area. Using Wight's (1979) empirical relationship:

$$
A_{g}=\frac{472 \times 10^{0.28 M}}{(R+25)^{1.3}}
$$

where: 
TABLE 22. Predicted Future Earthquakes for Hanford Area Over the Next Few Hundred Years

\begin{tabular}{|c|c|c|c|c|c|}
\hline Fault & Length & Depth & Area & $M$ & $\begin{array}{l}\text { Distance } \\
\text { from } 200 \text { Area } \\
\end{array}$ \\
\hline Saddle Mountain & $25 \mathrm{~km}$ & $10 \mathrm{~km}$ & $250 \mathrm{~km}^{2}$ & 6.6 & $20 \mathrm{~km}$ \\
\hline Untanum & $20 \mathrm{~km}$ & $10 \mathrm{~km}$ & $200 \mathrm{~km}^{2}$ & 6.5 & $10 \mathrm{~km}$ \\
\hline Walla Walla & $20 \mathrm{~km}$ & $10 \mathrm{~km}$ & $200 \mathrm{~km}^{2}$ & 6.5 & $100 \mathrm{~km}$ \\
\hline Wallula Gap & $5 \mathrm{~km}$ & $5 \mathrm{~km}$ & $25 \mathrm{~km}^{2}$ & 5.6 & $50 \mathrm{~km}$ \\
\hline
\end{tabular}

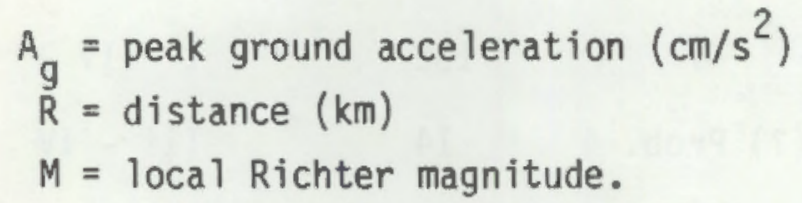

values of $0.24,0.32,0.06$, and $0.07 \mathrm{~cm} / \mathrm{sec}^{2}$ respectively, are obtained for peak accelerations of the four potential earthquakes shown in Table 22. Blume and Associates (1971), in work done for seismic design of nuclear reactors at Hanford, conservatively estimated that the maximum credible earthquake over the next 50 years is Richter magnitude 6.7 (modified Mercalli Intensity = VIII) located at the northwest end of the Rattlesnake-Wallula fault zone and resulting in $0.25 \mathrm{~g}$ acceleration on the Hanford Reservation. Wight (1979) has calculated that an annual probability of the maximum ground acceleration of exceeding $0.20 \mathrm{~g}$ in the area is $10^{-4}$.

Wight concludes that with careful attention to matching acoustic impedances between country rock and backfill material, vibratory effects should be minimized and shaft seal failures caused by large earthquakes may be avoided. A hypothetical seal failure is shown in Figure 40 . Some data on tunnel damage are presented in Figure 41 and Table 23.

\section{Impact Fracturing}

Impact fracturing is related to phenomena such as meteorite impact. The suggestion has been made that below a crater a fracture zone exists that is about four times the depth of the crater (Hartman 1979). Thus, a meteorite 


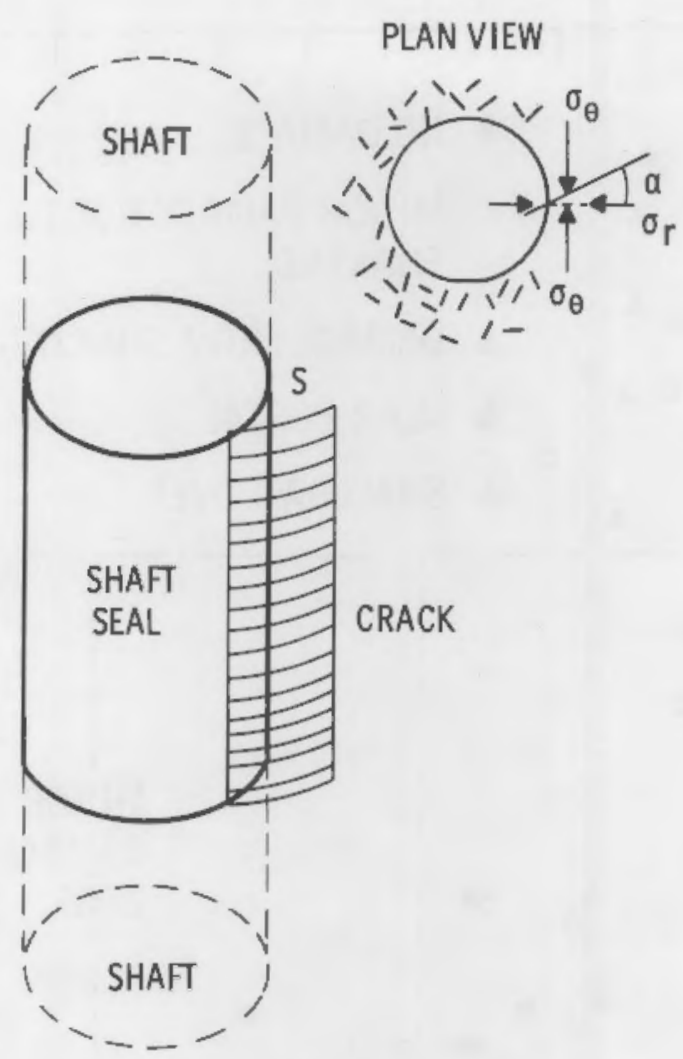

FIGURE 40. Assumed Crack Geometry Around Shaft Seal (Little 1978)

about four times the depth of the crater (Hartman 1979). Thus, a meteorite might breach the repository without excavating it. This will be further discussed in the section on meteorites.

\section{Hydraulic Fracturing}

The final potential fracture mechanism considered in this study hydraulic fracturing. Extension fractures associated with hydraulic fracturing are found in a wide variety of geologic settings. Typically these cracks are filled with fluid (e.g., water, oil, gas, air) and it appears that fluid pressure and pressure gradients have played an important role in dilation artd propagation of the fractures (Pollard 1978).

An example of extensional fracturing is hydro-fracturing. The assumption is that material overlying the basement rock has relatively low tensile 


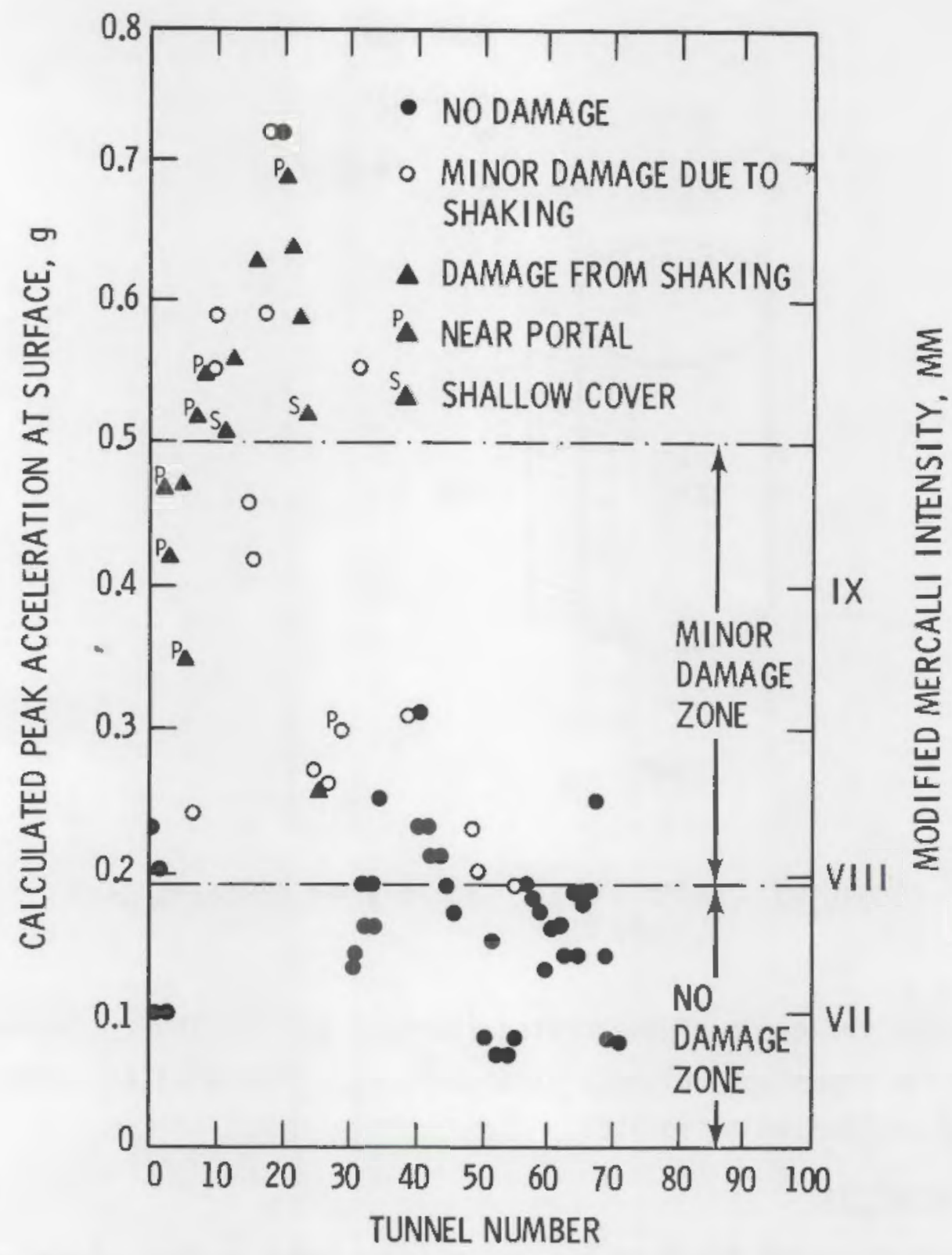

FIGURE 41. Calculated Peak Acceleration at the Surface and Associated Tunnel Damage (Pratt et al. 1978)

strength. If the interstitial or pore fluid pressure is increased to the magnitude of the minimum principal stress, the material is fractured in a dilational mode with the fracture plane orientation being basically perpendicular to the minimum principal stress. 
TABLE 23. Summary of Damage Levels (Pratt et al. 1978)

STRONG, TENSILE, AND SOME RADIAL CRACKING (BAUER, CALDER)

FORMATION OF NEW CRACKS IN ROCK (LANGEFORS, LINDSTROM)

FALL OF STONES IN UNLINED ROCK TUNNELS (LANGEFORS, LINDSTROM)
DISTANCE, MAGNITUDE

$\mathrm{km}$

\begin{tabular}{|l|l}
\hline 5 & \\
5 & 6.5
\end{tabular}

6.5

6.0

5

6.5

DAMAGE TO STEEP, WEATHERED ROCK (ORIARD) NO DAMAGE TO COMPETENT ROCK (ORIARD)

DAMAGE TO UNSOUND ROCK

6.0

5.0

FALLING OF PARTIALLY LOOSENED ROCK

OCCASIONAL FALLING OF LOOSE STONES

SAFE (ORIARD) 
Natural phenomena may result in perturbation to the hydraulic system that could result in abrupt increases in hydraulic potentials, repository flooding, and possibly hydraulic fracturing. Such changes could be produced by a variety of causes, including local ponding of rivers, changes in ocean levels related to world wide glaciation, erosion of sediments in river valleys, or changes in available moisture caused by climatic changes. In northern regions the re-expansion of continental ice sheets could result in very high subglacial pressures being transmitted to aquifers. (a) The current program thrust is toward quantifying and ranking these processes in terms of induced permeabilities, fluid potential changes, and volumetric flows.

Natural changes in the hydrologic system may be slow enough to allow the system to approach equilibrium without the development of large transient local hydraulic gradients. Davis has suggested that hydraulic gradients in excess of 0.3 are not likely in deep zones of actively circulating water (a). However, because extensional fractures do occur in nature and fluid pressures appear to have played a role in their development and propagation, this fracture mechanism must be considered.

Summary

This section on deformation covers: 1) undetected and/or accelerated deformation of the basalts, 2) deformation in the sub-basalt basement strata, 3) impact fracturing, and 4) hydraulic fracturing. Deformation can affect pathlengths, hydraulic conductivities, fluid potentials and effective stresses.

Undetected and/or accelerated deformation of the basalts refers to folding and associated faulting. Emphasis is placed on undetected features. An example estimate of the frequency and magnitude of undetected deformation is made based on recorded seismicity, inferred geologic slip rates, and observed anticlinal deformation. It is concluded that in any $10^{2} \mathrm{~km}^{2}$ area there is

(a) This information is based on work done by Davis which is reported in part in this document. A summary of Davis' research has been published (Davis 1979). 
a $10^{-6} \mathrm{yr}^{-1}$ or less probability of a strain energy release comparable to a moderately sized earthquake. This strain energy release might be in the form of a single earthquake; however, it might be that deformation will be manifested as small displacements on pre-existing joints or other planes of weakness. This small scale (microseismic) activity may prevail in the Columbia Plateau region. Permeability changes potentially associated with such deformation are being estimated based on a theoretical parallel plate model and estimated joint spacing and aperture width. This approach is anticipated to grossly overestimate the induced permeability changes. The tortuosity of the basalt fracture system may be so high that quantifying a significant flow path is not possible.

For the Columbia Plateau region, tectonic forces are assumed to be constant, but strain rates may vary in the future. Currently the regional average

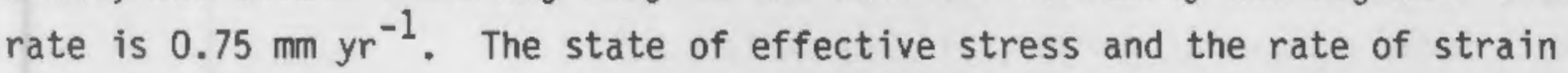
are two key variables in estimating the type of faulting and associated probabilities and magnitudes.

Faulting in the sub-basalt basement is estimated based on the undetected feature concept. Estimates based on geometrical manipulations of known fault density may not be conservative and, given the nature of the basalt cover, yield erroneous results. The type and magnitude of basalt deformation indicates the possibility of glide motion at depth. Additional strain rate measurements on the basalt structures and continued monitoring of deep-seated seismicity appears essential. The assumption has been made that an undetected fault may run immediately adjacent to a repository but does not initially intersect it. Such a feature might not be discovered during construction of the repository. Rupture of a fault running close to a repository but not through it might result in secondary or sympathetic displacement on joints. Fault displacement of 0.1 to 1.0 meters and joint displacement of a few centimeters are being assumed for any individual event. Results such as permeability changes, accelerations, and total duration of shaking are being estimated. These estimates are used as input in a shaft seal failure submodel. This model considers the acoustic impedance mismatch in the system. 
Impact fracturing, and hydraulic fracturing are all being assumed to be relatively insignificant in the Columbia Plateau region. Figures 42,43 , and 44 present the logic flow diagrams for the basalt deformation, sub-basalt basement faulting, and shaft seal failure submodels. Tables 24,25 , and 26 list data requirements and data availability.

It should be emphasized that this section is a description of an example submodel. As such, there is reason to assume that many of the assumptions and components will be altered in the future to accomodate new understanding of the geological and geophysical characteristics of the Columbia Plateau.

\section{METEORITES}

This section is devoted to: 1) an argument for dismissing meteorite scenarios from further consideration, and 2) a logic flow and data presentation of how to handle these scenarios, if necessary.

Argument to Eliminate Future Meteorite Analyses

Assume that the probability of a single meteorite strike sufficient to breach the repository is Po for any given year. The probability of this not taking place is $P 1,0=1-P_{0}$. The probability of this not taking place in $n$ years is $P n, O=\left(1-P_{0}\right)^{n}$, and therefore the probability of it occurring at least once in $n$ years is $P_{n}, 1=1-\left(1-P_{0}\right)^{n}$.

In his paper on "The Significance of the Rare Event in Geology," Gretener (1967) shows that for small P1, that $\mathrm{Pn}, 1$ can be adequately expressed in the well-known Poisson limit for the binomial distribution:

$$
P_{n, 1}=1-1-\left(\frac{n}{1}\right) P_{0}+\left(\frac{n}{2}\right) P_{0}^{2}-\left(\frac{n}{3}\right) P_{0}^{3}+\ldots
$$

The age of the earth will be used as the yardstick against which the liklihood of the meteorite impact will be measured. The age of the earth is between 3.5 and $5.5 \times 10^{9}$ years old (Holmes 1960). Therefore, if an event has a yearly probability $P_{0}$ of $10^{-7}$, it still has a $98 \%$ chance of happening in a time period equal to the age of the earth. But if $P_{0}=10^{-10}$, it only has a $20 \%$ chance. An event with a yearly probability of $10^{-11}$ or less has virtually no chance of occurring over a time span equal to the age of the earth 


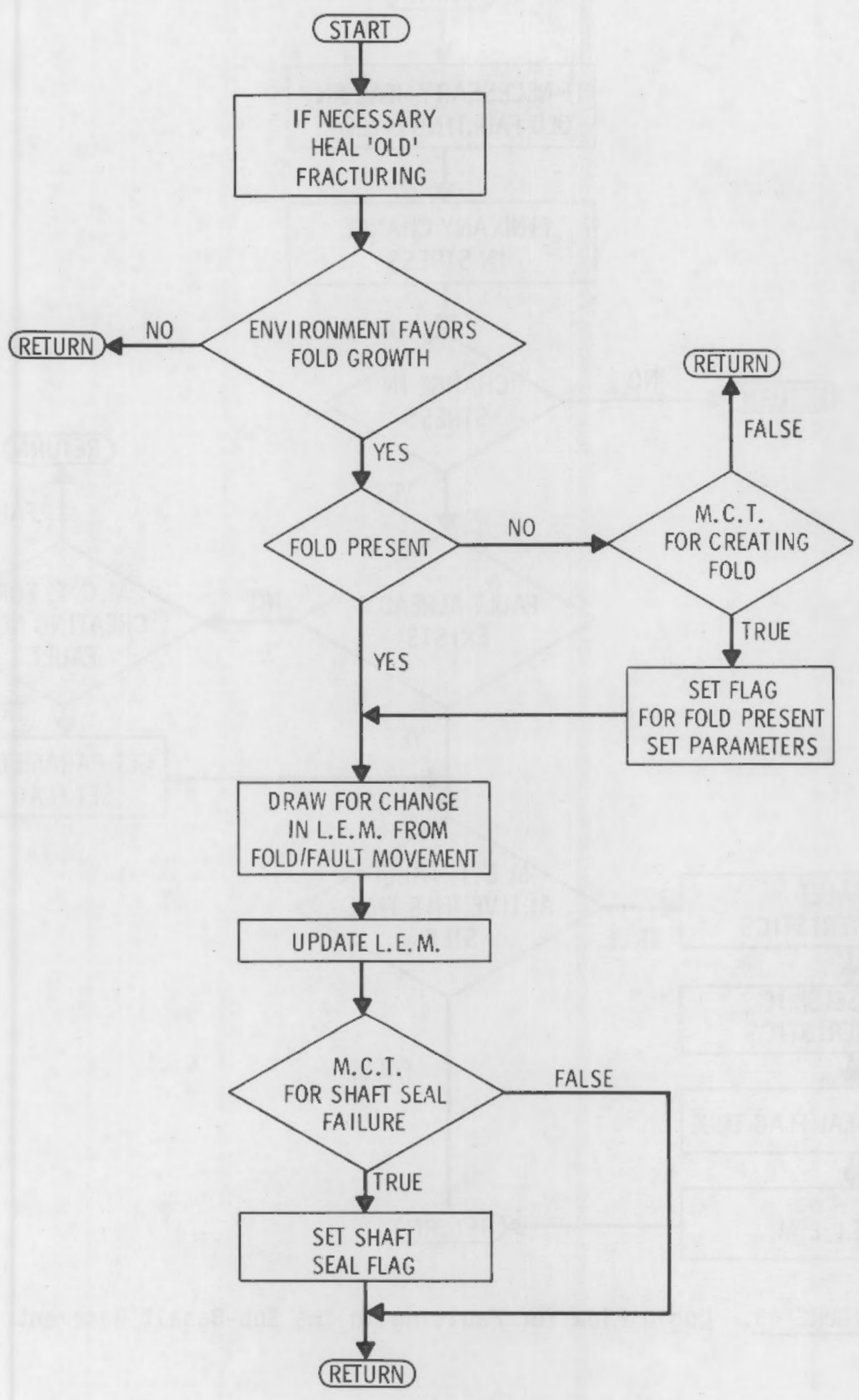

FIGURE 42. Logic Flow Diagram for Deformation 


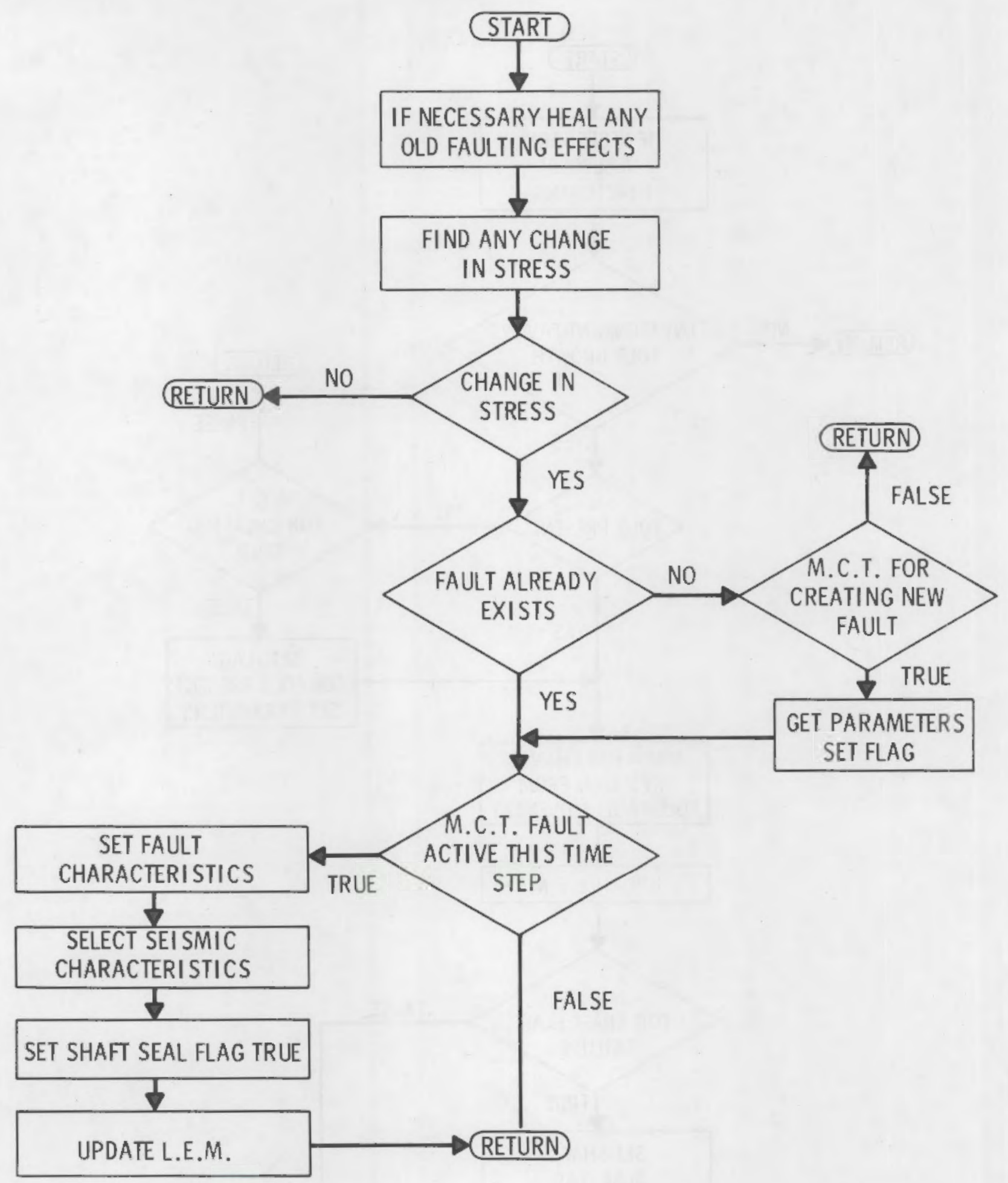

FIGURE 43. Logic Flow for Faulting in the Sub-Basalt Basement 


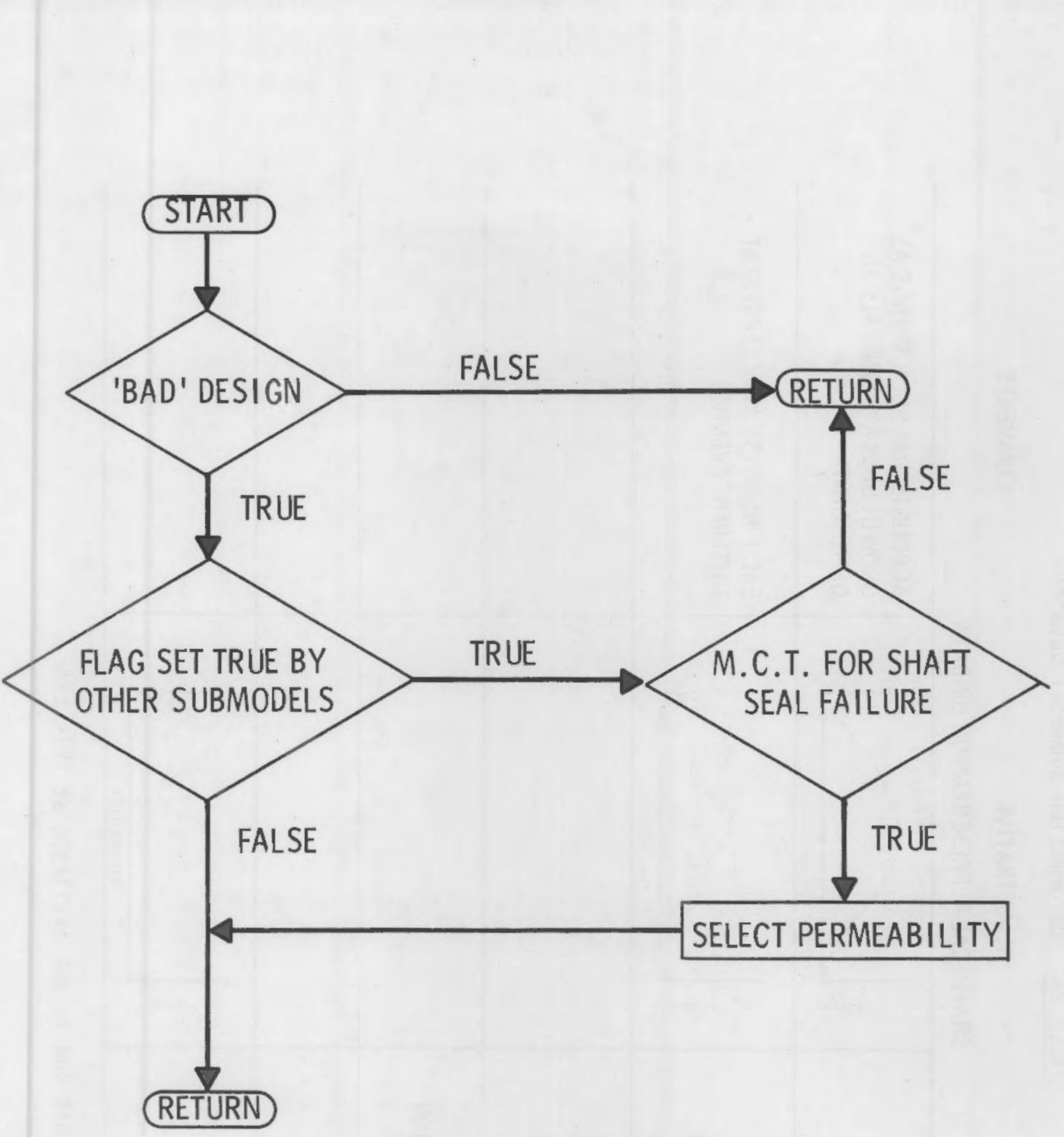

FIGURE 44. Logic Flow for Shaft Seal Failure Submodel

(Gretener 1967). For a single repository $600 \mathrm{~m}$ deep, the probability of excavation by a meteorite is found to be on the order of $10^{-11}$ to $10^{-13}$ per year (Hartman 1979). Thus, even if the wastes have to remain isolated for a time equal to the age of the earth, they would be exceedingly safe from meteorite impact. 
TABLE 24. Deformation Submodel Data (a)

SUBJECT

ILLUSTRATIVE

COMMENTS

GRAPHICAL REPRESENTATION OR DATA

\begin{tabular}{|c|c|c|}
\hline $\begin{array}{l}\text { DENSITY FUNCTION FOR } \\
\text { 'HEALING' }\end{array}$ & $L_{0}$ & $\begin{array}{l}\text { ACCOUNTS FOR SUCH THINGS AS } \\
\text { GROWTH OF CLAY MINERALS IN } \\
\text { OPEN JOINTS }\end{array}$ \\
\hline $\begin{array}{l}\text { DENSITY FUNCTION FOR } \\
\text { FOLD/ FAULT MOVEMENT IN } \\
\text { L.E.M. GIVING CHANGE IN } \\
\text { VERTICAL CONDUCTIVITY }\end{array}$ & $\sum_{0}^{\vdots}$ & $\begin{array}{l}\text { EACH 'HUMP(S)' MAY REPRESENT } \\
\text { DIFFERENT EVENT(S) }\end{array}$ \\
\hline $\begin{array}{l}\text { DENSITY FUNCTION FOR } \\
\text { FOLD/FAULT MOVEMENT IN } \\
\text { L.E.M. GIVING CHANGE IN } \\
\text { LATERAL CONDUCTIVITY }\end{array}$ & & \\
\hline $\begin{array}{l}\text { CHANCE FOR SHAFT SEAL } \\
\text { FAILURE GIVEN DEFORMATION } \\
\text { IN L.E.M. }\end{array}$ & & \\
\hline \multicolumn{3}{|l|}{$\begin{array}{l}\text { CHANCE FOR CREATING A } \\
\text { 'NEW' FOLD }\end{array}$} \\
\hline & TRANSMISSIVITY & \\
\hline
\end{tabular}

(a) Data is under development and is not available at this time. 
TABLE 25. Sub-Basalt Basement Fault Data ${ }^{(a)}$

SUBJECT

ILLUSTRATIVE

COMMENTS

GRAPHICAL REPRESENTATION OR DATA

\begin{tabular}{l|l|l}
\hline DENSITY FUNCTION FOR 'SIZE' & ON A SCALE OF 0.0 TO 1.0 \\
OF FAULT & & \\
\hline $\begin{array}{l}\text { CHANGE IN STRESS IN NORTH- } \\
\text { SOUTH DIRECTION }\end{array}$ & & \\
\hline $\begin{array}{l}\text { CHANGE IN STRESS IN EAST-WEST } \\
\text { DIRECTION }\end{array}$ & & \\
\hline CHANGE IN VERTICAL \\
PERMEABILITY OF L.E.M. & & \\
\hline CHANGE IN LATERAL \\
PERMEABILITY OF L.E.M.
\end{tabular}

(a) Data is under development and is not available at this time. 
TABLE 25. (contd)

SUBJECT

ILLUSTRATIVE

COMMENTS

GRAPHICAL REPRESENTATION OR DATA

\begin{tabular}{l|l|l}
\hline MAXIMUM DISPLACEMENT & & \\
\hline MAXIMUM WIDTH & & \\
\hline MAXIMUM LENGTH & & \\
\hline MAXIMUM PERMEABILITY & & \\
\hline MINIMUM PEAK ACCELERATION & & \\
\hline MINIMUM VELOCITIES & & \\
\hline MINIMUM FREQUENCIES & & \\
\hline MINIMUM DURATION & & \\
\hline STARTING NORTH-SOUTH & & \\
\hline STRESS & & \\
\hline STARTING EAST-WEST & & \\
\hline STRESS & & \\
\hline CHANCE FOR A FAULT & & \\
\hline MAXIMUM PEAK ACCELERATION & & \\
\hline MAXIMUM VELOCITIES & & \\
\hline MAXIMUM FREQUENCIES & & \\
\hline MAXIMUM DURATION & & \\
\hline
\end{tabular}


TABLE 26. Shaft Seal Failure Submodel Data ${ }^{(a)}$

SUBJECT

ILLUSTRATIVE

COMMENTS

GRAPHICAL REPRESENTATION OR DATA

\begin{tabular}{l|l|l|l}
\hline DENSITY FUNCTION FOR & MLIOARCIES & \\
CHANGE IN PERMEABILITY & OF SHAFT & & \\
\hline OHANCE OF SHAFT BEING & & \\
AFFECTED BY OTHER \\
DEFORMATION/ENERGY \\
EVENTS IN OTHER \\
SUBMODELS
\end{tabular}

(a) Data is under development and is not available at this time. 


\section{Preliminary Analysis}

Based on analyses of cratering on the earth and on moon, relationships between meteorite size, excavation depth, crater diameter, and fracture zone depth have been developed (Hartman, 1979). Probabilities are assigned to each discrete excavation depth. These relationships are shown in Figures 45, 46, and 47 and Table 27.

The meteorite is treated as a random event in the submodel. If a meteorite strike is selected in a given time step, the Layer Earth Model characteristics are updated to reflect the crater and fracture zone. The fracture zone depth is considered to be up to four times the depth of the crater (Hartman 1979).

The latest study on energy partitioning during high velocity impacts (0'Keefe and Ahrens 1977) supports the following energy division: 1) $40 \%$ goes to heating of the target, 2) $50 \%$ into crushing and plastic deformation and vibratory excitation, and 3) $10 \%$ into ejector kinetic energy. The vast majority of the ejector related energy goes into lifting masses of shattered rock, which fall back into the crater to form part of the rubble zone, or fall slightly to the side of the crater to form an extended rim.

If the crater intersects the repository, 0.5 to $5.0 \%$ of the waste might be dispersed to the atmosphere. The remainder will be available for leaching by surface and ground waters. If only the fracture zone reaches the depth of the waste, ground water may leach the waste and presumably be in communication with the inundated crater. Subsequent preferential erosion is also considered. The biggest unknown is the permeability associated with such a rubble zone and the direction and magnitude of advective transport, if any.

\section{Sumnary}

An argument is presented to dismiss meteorites from future discussions in studies of repositories buried $300-600 \mathrm{~m}$ deep. This argument is based on relative probability of $10^{-11}$ to $10^{-13} \mathrm{yr}^{-1}$ for the site being affected by excavation or impact fracturing. If further analys is is warranted, many of the necessary relationship between crater diameters, crater and fracture zone 


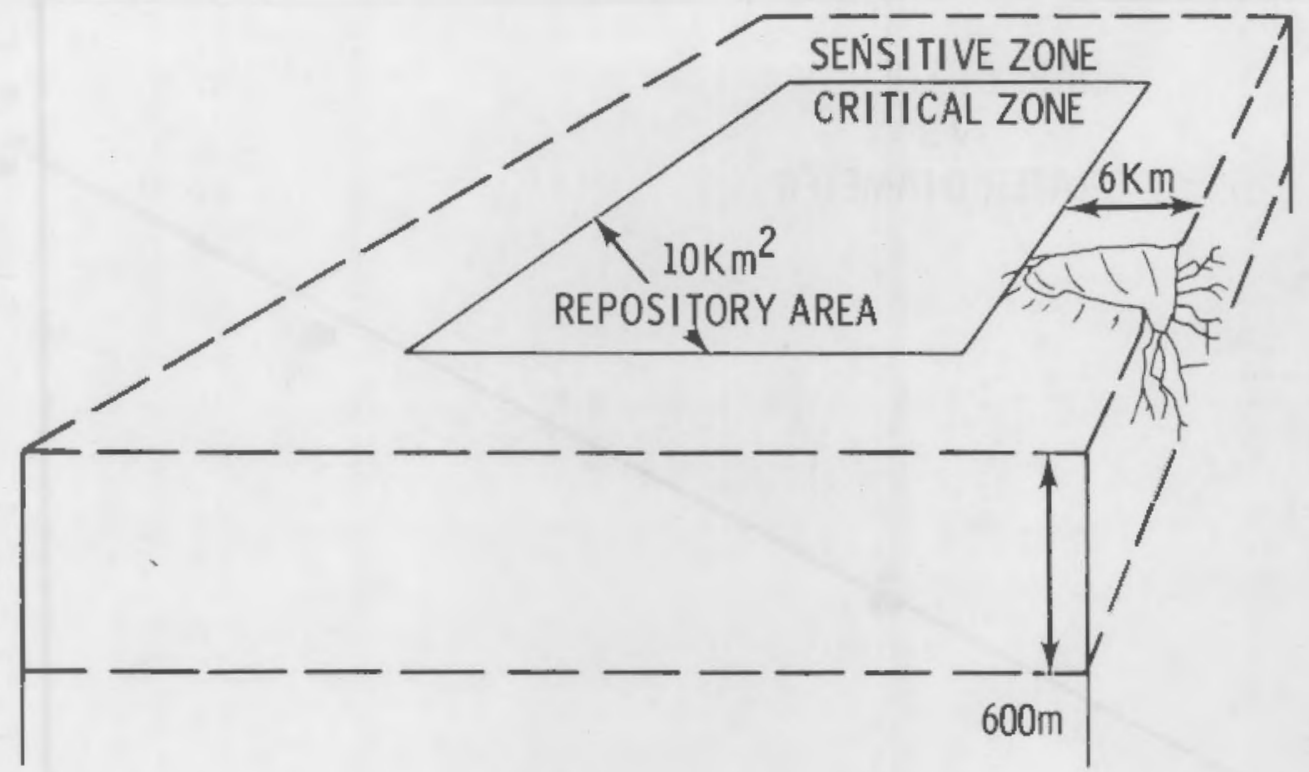

FIGURE 45. Critical and Sensitive Damage Zones for Metorite Impacts (Hartman 1979)

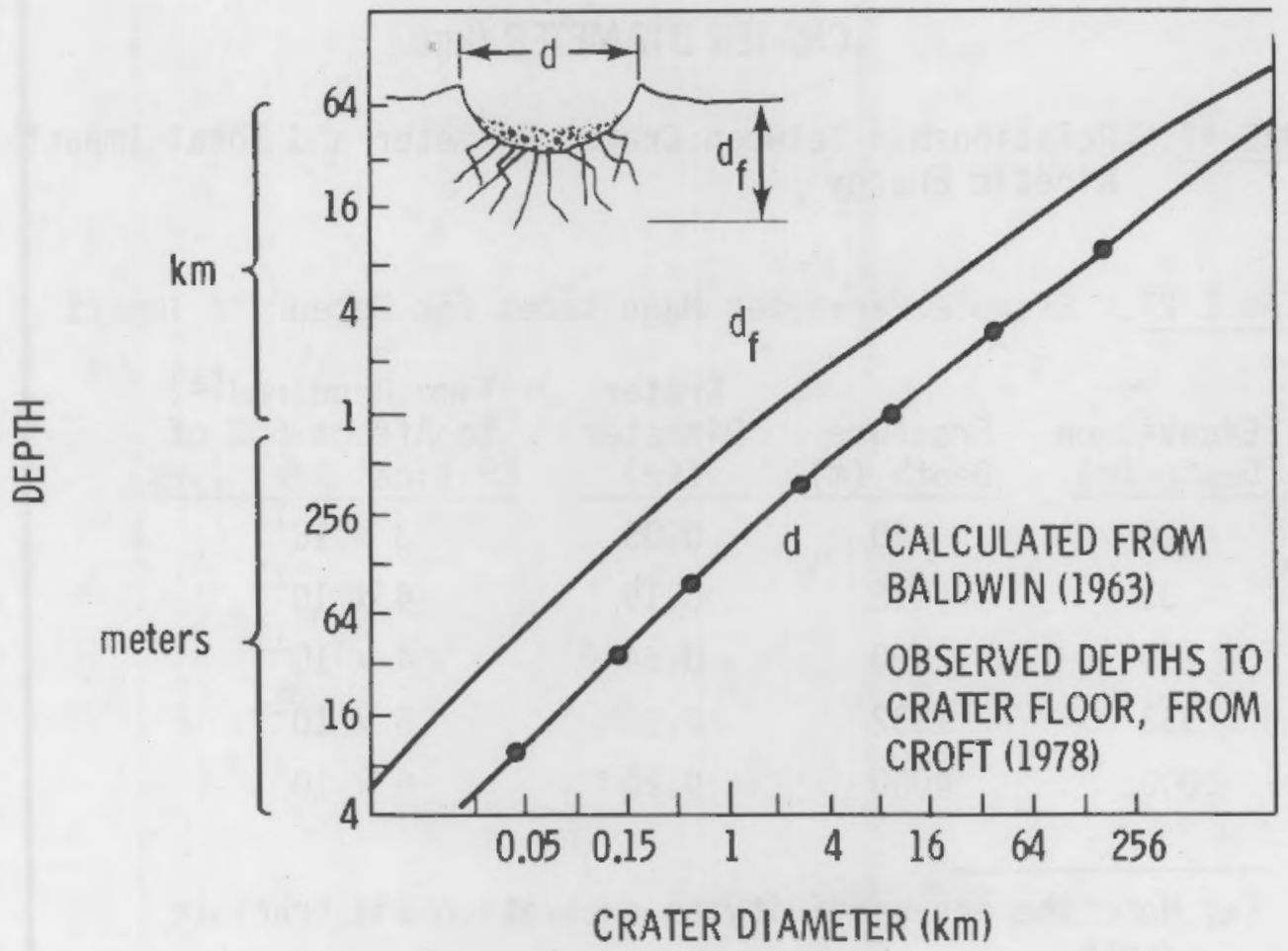

FIGURE 46. Relationship Between Crater Diameter (D), Depth of Excavation (d) and Depth of Fracturing ( $\left.d_{f}\right)$ (Hartman 1979) 


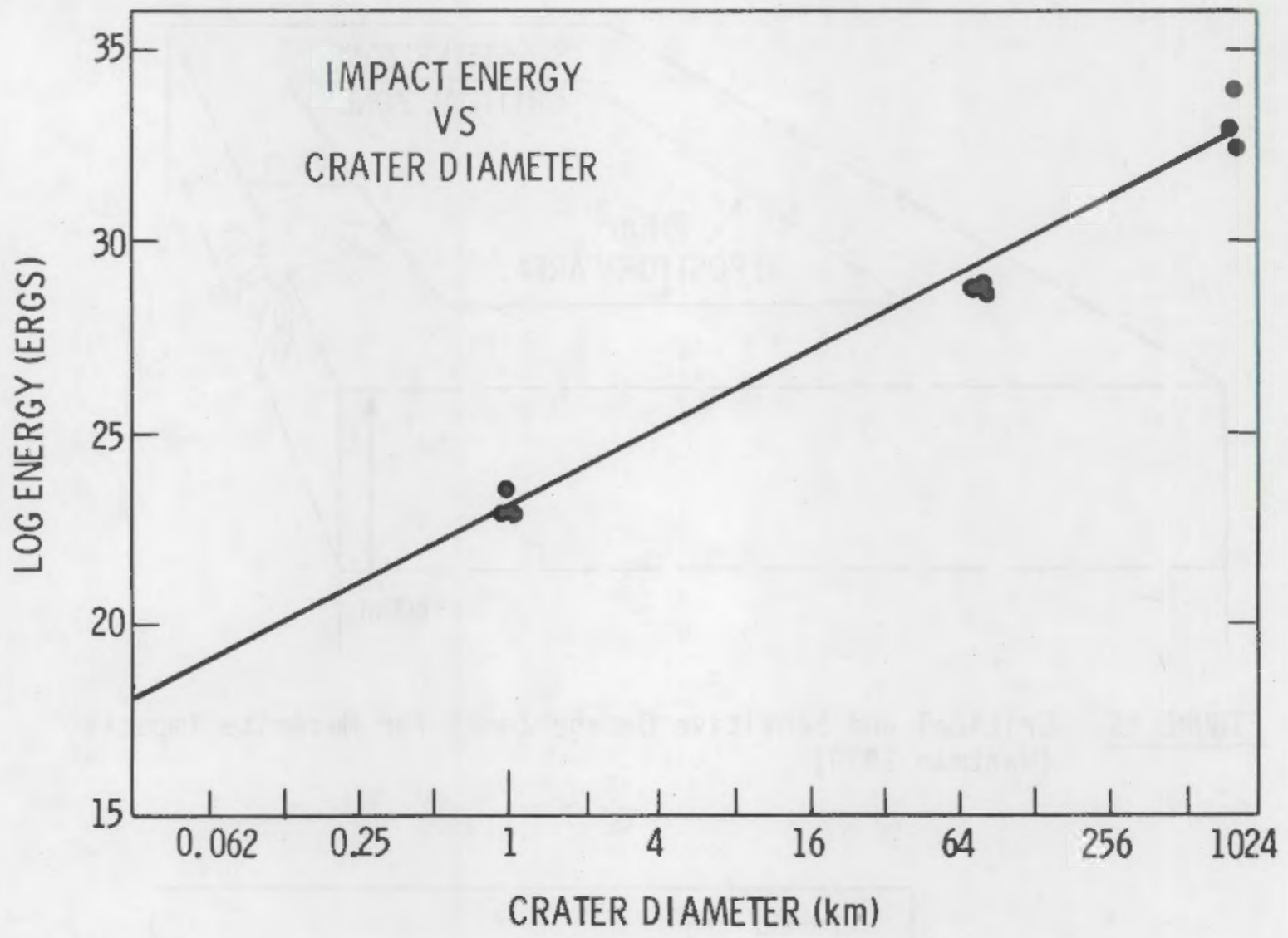

FIGURE 47. Relationship Between Crater Diameter and Total Impact Kinetic Energy

TABLE 27. Example Parameter Magnitudes for Meteorite Impact

\begin{tabular}{|c|c|c|c|}
\hline $\begin{array}{l}\text { Excavation } \\
\text { Depth (m) }\end{array}$ & $\begin{array}{l}\text { Fracture } \\
\text { Depth (m) }\end{array}$ & $\begin{array}{c}\text { Crater } \\
\text { Diameter } \\
(\mathrm{km}) \\
\end{array}$ & $\begin{array}{l}\text { Time Required (a) } \\
\text { to Affect } 60 \% \text { of } \\
\text { Critical Area (yrs) } \\
\end{array}$ \\
\hline 10 & 40 & 0.05 & $3 \times 10^{11}$ \\
\hline 33 & 132 & 0.19 & $4 \times 10^{11}$ \\
\hline 100 & 400 & 0.64 & $4 \times 10^{11}$ \\
\hline 333 & 1332 & 2.50 & $5 \times 10^{11}$ \\
\hline 1000 & 4000 & 9.20 & $6 \times 10^{11}$ \\
\hline
\end{tabular}

(a) Note the insensitivity to excavation and fracture depth 


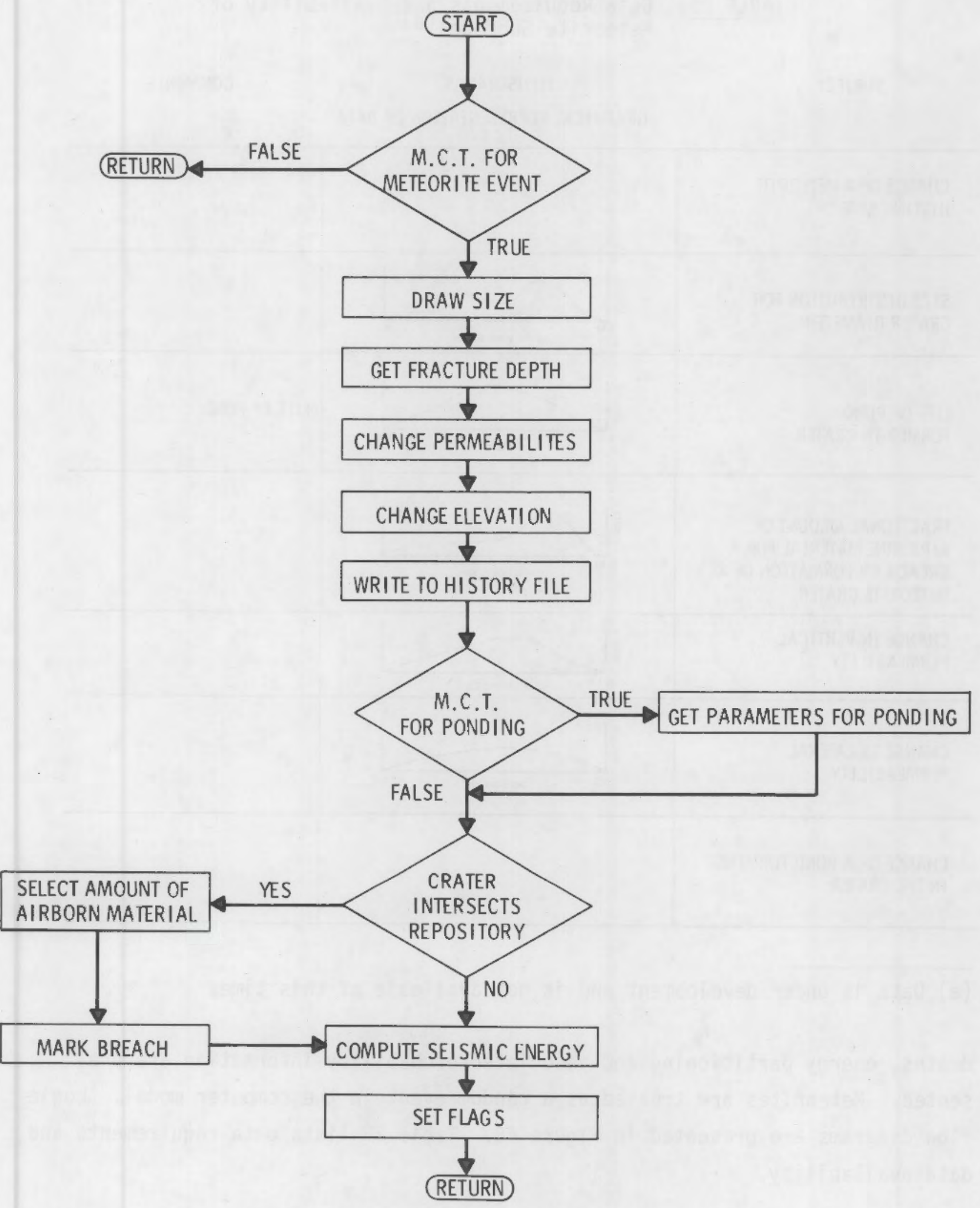

FIGURE 48. Logic Flow Diagram for Meteorite Submodel 
TABLE 2B. Data Requirements and Availability of Meteorite Submodel(a)

SUBJECT

ILLUSTRATIVE

COMMENTS

GRAPHICAL REPRESENTATION OR DATA

\begin{tabular}{l|l|l|}
\hline CHANCE OF A METEORITE & & \\
HITIING SITE & & \\
\hline
\end{tabular}

(a) Data is under development and is not available at this time.

depths, energy partitioning and associated probability information are presented. Meteorites are treated as a random event in the computer model. Logic flow diagrams are presented in Figure 48 . Table 28 lists data requirements and data availability. 


\section{MAGMATIC ACTIVITY}

In general, magmatic activity can be manifested in numerous ways, some of which are mutually exclusive, e.g., basalt lava plateaus vs. explosive volcanic eruptions. Figure 49 shows several features associated with igneous and volcanic activities. Table 29 lists the characteristics of some common volcanic features. In general, volcanic activity is quite rare in stable midcontinental areas. Only $3 \%$ of the world's volcanos are found in midcontinental areas, and most of these are associated with the African rift system. However, to dismiss the subject of volcanism affecting a waste repository in the Columbia Plateau region would be difficult. The Columbia River Plateau represents one of the few known examples of flood basalts, with a total volume probably in excess of $259,000 \mathrm{~km}^{3}$ and a centerpoint thickness of $8-10 \mathrm{~km}$. The basalt stratigraphy consists of a thick sequence of homogeneous lava flows varying in thickness from $3 \mathrm{~m}$ to perhaps $150 \mathrm{~m}$. The main mass of basalt was probably extruded between 14 and 17 million years ago, although the youngest flow (Ice Harbor) may only be 8 million years old. The extent of the basalt covering is shown in Figure 50. A schematic of multiple flow stratigraphy is shown in Figure 51.

Successive flows are sometimes interrupted by weathered zones or sedimentary interbeds deposited during the quiescent period between basalt floods. In general, the basalt flows were erupted from fissures aligned in linear vent systems. Feeder dikes, chiefly vertical and oriented north to north-northwest, occur throughout the eastern two-thirds of the plateau (Tauberneck 1970, Swanson et al. 1975). To date, no feeder dikes have been found in the Pasco Basin.

The north-south alignment of dike feeders suggests an east-west crustal extension and possible subsidence of the Pasco Basin in Late Tertiary Time. Zoback and Thompson (1977) regard the northern feeder dikes as part of a major system $700 \mathrm{kilometers} \mathrm{in} \mathrm{length,} \mathrm{extending} \mathrm{from} \mathrm{the} \mathrm{dike} \mathrm{swarms} \mathrm{in} \mathrm{Northern}$ Nevada through the western Snake River Plain into the Columbia Plateau. Thus, the east-west crustal extension during the Late Tertiary, at least in the eastern portion of the Columbia Plateau, has changed to north-south compression during the present stress regime. Not only has the orientation of the principal stress been altered, but the intensity of the stress has diminished 


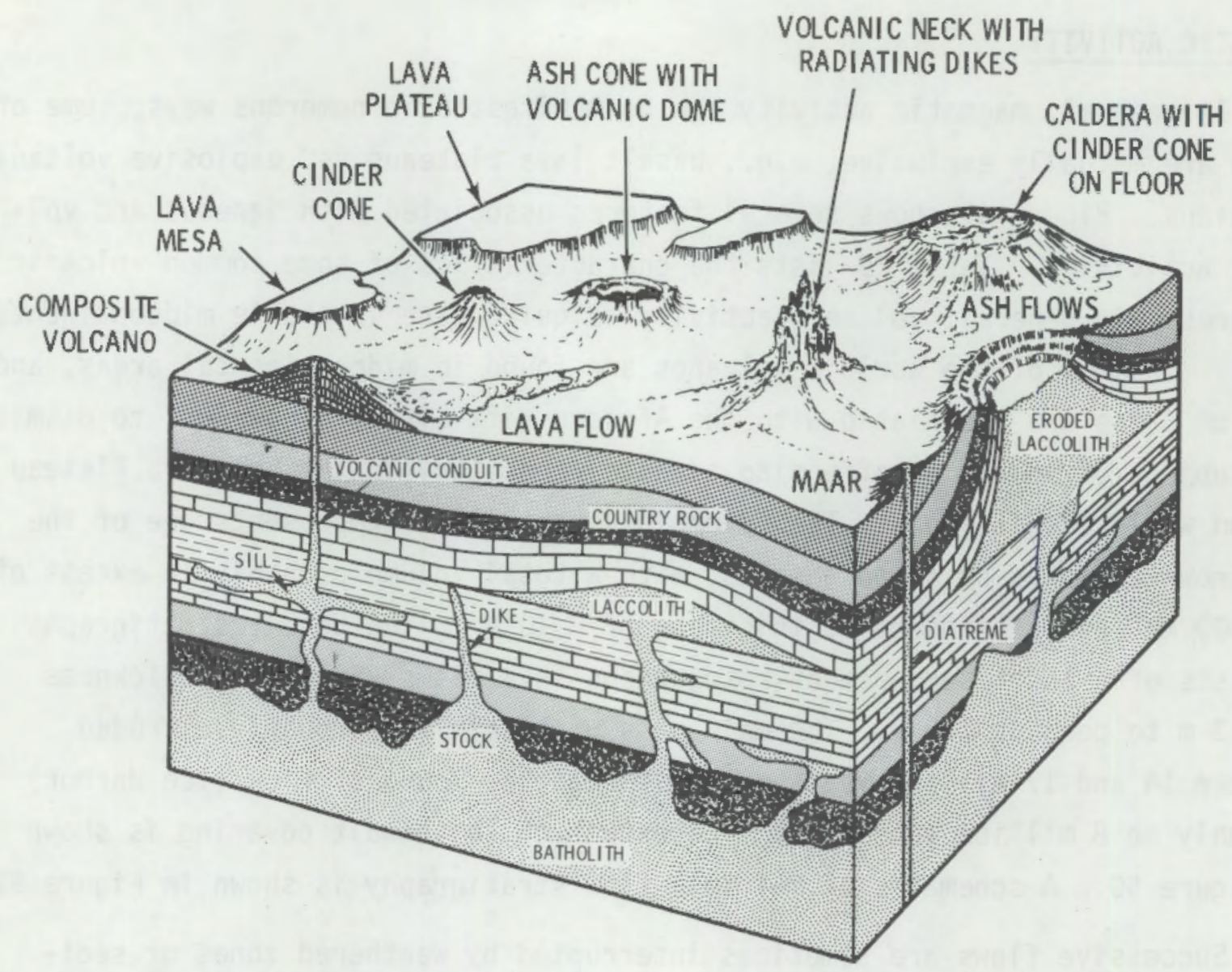

FIGURE 49. Block Diagram of Plutonic and Volcanic Structures (U.S.G.S. Atlas of Volcanic Phenomena)

considerably during the past several million years (Coombs 1979). Thus, the conditions for renewed flood basalt extrusion, may no longer exist. Furthermore such a tensional stress regime should not be reproduced in the next million years. Naturally, this assumes that changes in the regional stress field are gradual and not sudden. Additionally, graphs showing time versus magma volume suggest volcanic activity peaked 15 to $13 \mathrm{~m} . y$. ago, decreased considerably until about $6 \mathrm{~m} . y$. ago, when it ceased. (a) Even though the

(a) This information is based on work done by Crowe, which is reprinted in this document. A summary of Crowe's research has been published (Crowe 1979). 
TABLE 29. Generalized Classification of Volcanic Activity Based on Approximate Magmatic Compositions(a)

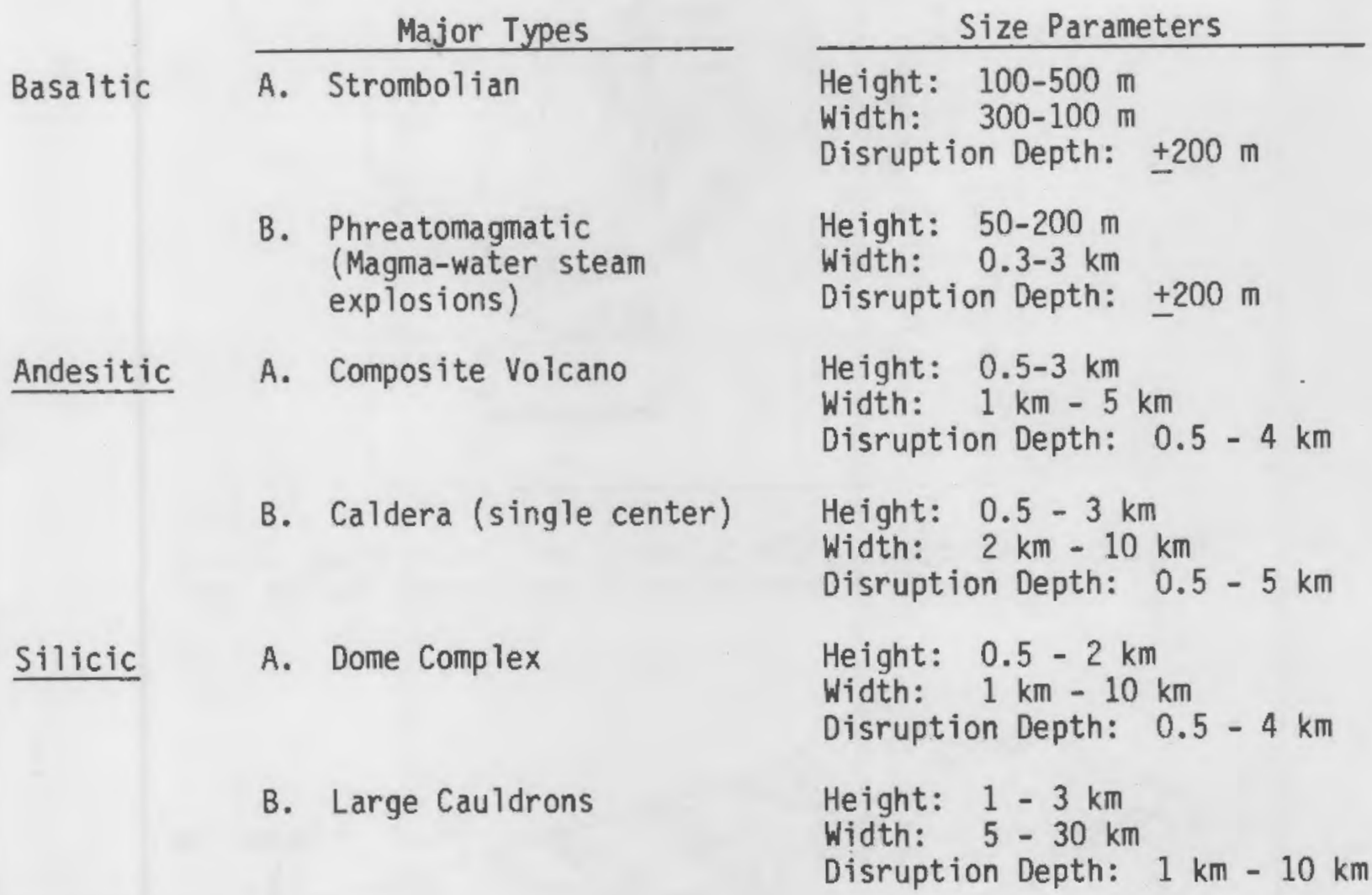

(a) This information is based on work done by Crowe, which is reprinted in this document. A summary of Crowe's research has been published (Crowe 1979).

probability of future volcanic activity in the Pasco Basin area appears to be exceedingly low, the history of the region dictates some consideration of the consequences associated with such activity.

Magma composition is another important factor to be considered. In general, basaltic eruptions tend to be nonexplosive and high.ly mobile and could transport radioactive material up to about $300 \mathrm{~km}$. The wastes could be entombed in the lava flow upon cooling and solidification. The Columbia River Flood Basalts are an excellent example of this magma composition. Silicic volcanic eruptions, on the other hand, are commonly highly explosive and repository material could be dispersed large distances and into the upper regions of the atmosphere. 


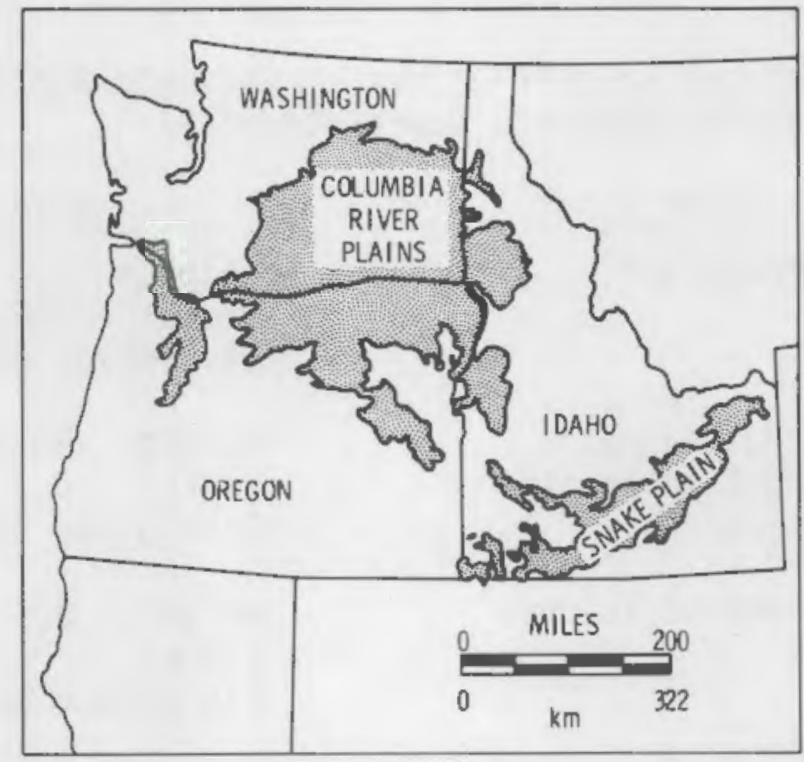

FIGURE 50. Map Showing the Columbia and Snake River Basalts of Northwestern United States (after Waters 1955)

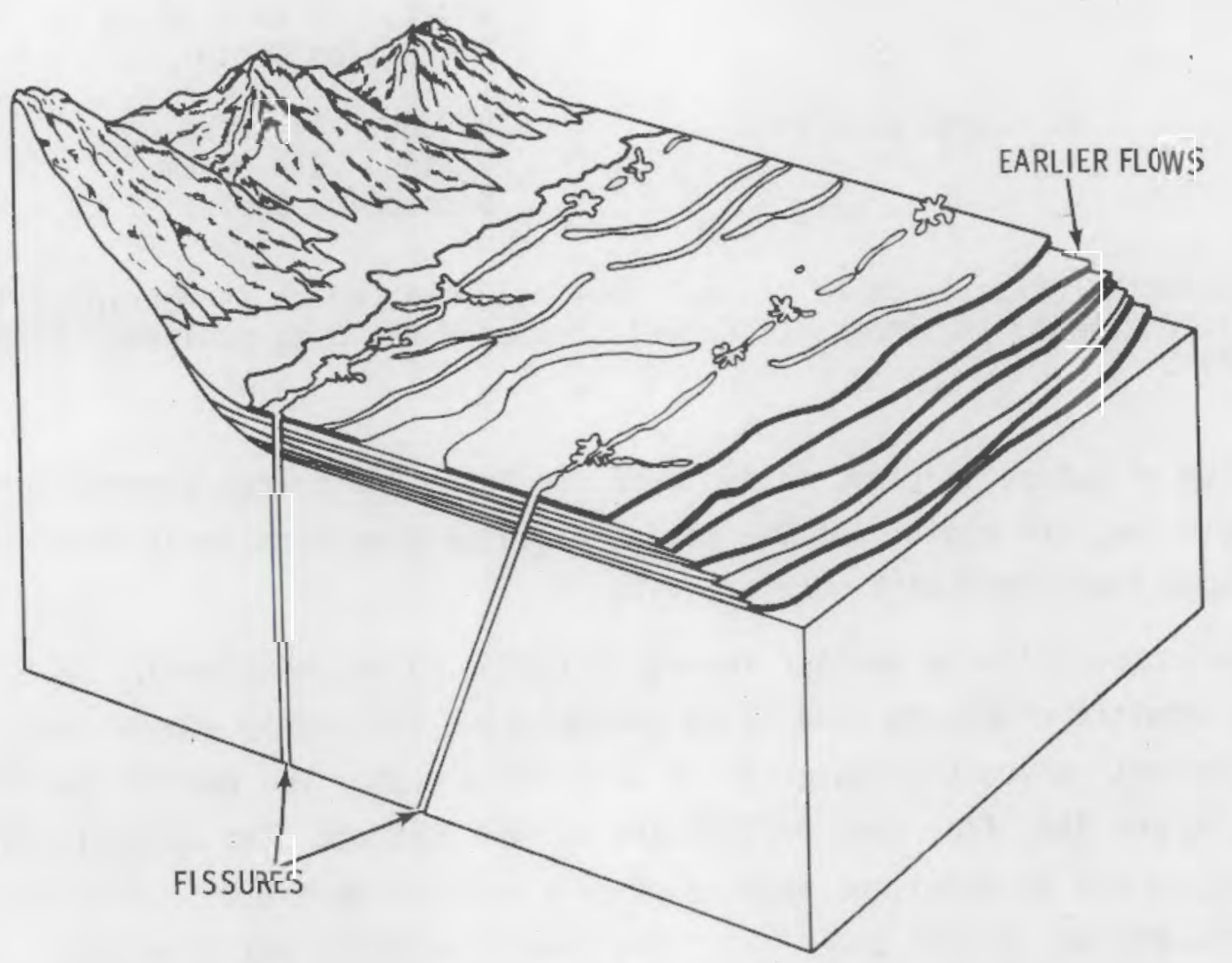

FIGURE 51. Schematic Diagram of Multiple Flows From Linear Fissures 
The exact location of the volcanic activity relative to the repository site is of importance. Direct intersection of the repository site by the volcanic conduit could result in immediate incorporation and transport of radioactive material. The range of sizes of typical basalt feeder dikes must be estimated for the Columbia Plateau. A 0.5 to $1.5 \mathrm{~km}$ zone around any feeder dike or linear vent will be presumably affected in a direct manner. The probability of intersection is a function of the distance to the feeder zone, the size of the feeder zone, the size of the repository and the probability of the feeder zone being active.

Assuming that the waste is contacted by extrusive magmatic material, several dispersal mechanisms are possible. Table 30 illustrates generalized transport distances of common volcanic processess associated with various types of volcanic eruptions. Dispersal mechanisms can be divided into two classes: 1) those mechanisms that are controlled by topography and are active primarily on the steep slopes of a volcano and adjacent areas (lava flows, volcanic mudflows, pyroclastic flow), and 2) air-fall activity that is controlled by the explosiveness of an eruption and prevailing wind directions. (a)

TABLE 30. Transport Distances and Eruption Types of Volcanic Events

\begin{tabular}{|c|c|c|c|c|}
\hline Magma Type & Lava Flows & Lahars & $\begin{array}{c}\text { Pyroclastic } \\
\text { Flow } \\
\end{array}$ & Air Fall \\
\hline Flood basalts & $300 \mathrm{~km}$ & -- & $-\infty$ & -- \\
\hline Basaltic "cinder cones" & $10 \mathrm{~km}$ & $5 \mathrm{~km}$ & -- & $30 \mathrm{~km}$ \\
\hline Basaltic "Phreatic" & $10 \mathrm{~km}$ & $6 \mathrm{~km}$ & $20 \mathrm{~km}$ & regional \\
\hline $\begin{array}{l}\text { Andesitic "composite } \\
\text { cone" }\end{array}$ & $5-10 \mathrm{~km}$ & $30 \mathrm{~km}$ & $30 \mathrm{~km}$ & regional \\
\hline Silicic "Crater Lake" & $5 \mathrm{~km}$ & $40 \mathrm{~km}$ & $50 \mathrm{~km}$ & global \\
\hline Decreasing & & Slope & & Wind \\
\hline Frequency & & Control & & Control \\
\hline
\end{tabular}

(a) This information is based on work done by Crowe, which is reprinted in this document. A summary of Crowe's research has been published (Crowe 1979). 
A special case of magmatic activity involves an igneous body rising to an unspecified depth below the repository site. The size of such an intrusive body can vary from square meters to thousands of square kilometers. Potential consequences of such emplacement would include: broad dome uplift and development of radial and concentric fracture systems, faulting, accelerated erosion rates, juxtaposition of a hydrothermal convection system above the magma chamber, and upward propagation and eruption of surface volcanism fed from the igneous body. This could be manifested as magma or steam as in a geyser. Parameters controlling the magnitude of these potential events include: depth of the igneous mass, dimensions and volume of the body, and residence time as a molten body (a function of initial cooling mechanisms and heat replenishment mechanisms).

In addition to volcanism that might occur at or immediately adjacent to the repository, a much higher probability exists for volcanic activity located wel1 away from the repository site. Potential effects decrease rapidly with increasing distance from the site. At distances greater than $50 \mathrm{~km}, \mathrm{e.g.,}$ the Cascade volcanoes, effects of many types of volcanic activity would be minimal. (a) Major silicic volcanic eruptions would have the following possible consequences: surficial mantling by air-fall pumice, vegetation, drainage, and erosional modifications, and climatic effects. (a) Major basaltic flows could result in surficial magma loading and potentially some diagenesis or physical alterations of sedimentary material in the vicinity of the repository. Shale and sandstone might be particularly sensitive to such burial and the associated increased pressures and temperatures.

In general, renewed volcanism in the immediate area of the repository is considered to be of only marginal significance because of its extremely small probability of occurrence. Based on a time versus magma volume graph, it can be shown that the peak of volcanic activity occurred in the range of 15-13 m.y. ago. Subsequent activity has been of considerably waning volume with no activity since the Pliocene. Additionally the stress regime active at the time

(a) This information is based on work done by Crowe, which is reprinted in this document. A summary of Crowe's research has been published (Crowe 1979). 
of the major extrusions no longer exists. Although estimates of the probability have been made in other studies, such an estimate for the Columbia Plateau region is premature until more is known about the deep structure of the area and the general tectonic relationships.

Summary

The subject of magmatic activity must be considered for any site in the Columbia Plateau region. However, the tensional stress regime that may have supported the tremendous outpouring of basalts some 8 to 17 million years ago is apparently no longer active. The area now seems to be in a state of gentle north-south compression, which is far different from that existing during the time of the major extrusive activity. Naturally a compressive stress regime does not eliminate the possibility of renewed volcanic activity, but it does tend to minimize it. Time versus magma volume graphs also suggest that major flood basalt activity has ended. Furthermore, renewed extrusions of basalt lava flows might prove beneficial to a deeply buried repository as long as the feeder dikes do not result in the release of radioactive materials or initiate elevated hydrothermal conditions in the vicinity of the repository. Also, incorporation of radioactive material in molten basalt appeares to be an effective method of stopping further migration of the material.

At distances greater than $50 \mathrm{~km}$, the effects of most types of volcanic activity would be minimal. Climate perturbations and changes in drainage and erosion patterns might be considered for this case, however. The probability for volcanism in the Cascade Mountains has been estimated to be $10^{-2} \mathrm{yr}^{-1}$ (Cranda 11 et al. 1975). As long as the site is 50-100 km away, however, this should not pose a threat. The probability of volcanic activity within the Columbia Plateau region is considered to be an order of magnitude less likely than the rupture of a deep seated fault. The logic flow diagram is presented in Figure 52. Data requirements and availability are in Table 31.

\section{UNDETECTED FEATURES}

Undetected features include numerous features, such as boreholes, basalt ic ring structures, flow terminations, lava tubes, remnant stream beds, and folds and faults, which were discussed previously. The basic consequences associated 


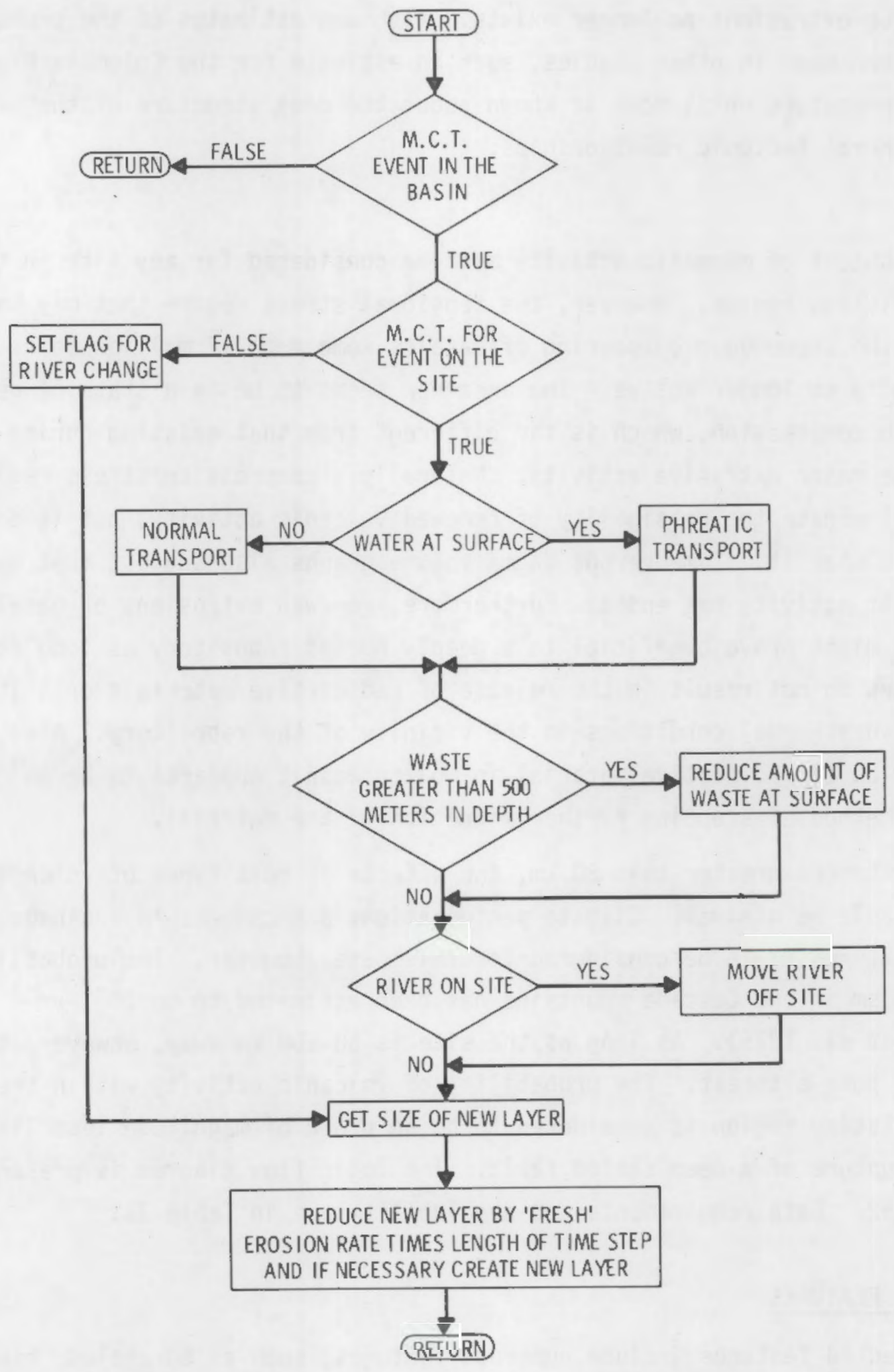

FIGURE 52. Logic Flow for Magmatic Submodel 
TABLE 31. Magmatic Activity Submodel Data(a)

SUBJECT

ILLUSTRATIVE

COMMENTS

GRAPHICAL REPRESENTATION OR DATA

\begin{tabular}{l|l|l|l|}
\hline FRACTIONAL AMOUNT OF WASTE & \\
INTRODUCED INTO THE AIR \\
IN A "NORMAL" MAGMATIC \\
BREACH
\end{tabular}

(a) Data is under development and is not available at this time.

with these features are: 1) they could provide a short circuit path between confined aquifers, and 2) they could be sources of significant quantities of ground water. The logic flow diagram is shown in Figure 52.

These features will not intersect the repository, because they would be discovered during excavation. Therefore, they cannot initiate breaches and are only associated with the transport paths once migration has started because of a breach initiated by some other disruptive phenomena. Furthermore, with 
the exception of the borehole, the features should not create a continuous vertical flowpath to the surface. The features are likely associated with a single basalt flow, if in fact they are present at all. Therefore, the transport pathway associated with undetected features would be expected to be a stair-stepped one (Figure 53). Undetected features might result in the discharge point for the leached nuclides, if any, being somewhat different from that expected. Therefore, these possible bridges between aquifers must be studied and the possibility of shorter than expected travel times to the biosphere be analyzed. Some of these features and their possible consequences are discussed in the following text.

Undetected Boreholes

Project Salt Vault is an example of the problems associated with undetected boreholes. Speculation is that such features may have been at least partly responsible for the disappearance of a quarter of a million gallons of injected non-contaminated water during the testing of a possible waste storage site. No assessment has as yet been made of this potential problem for a site in the Columbia Plateau. Essentially all borehole holes are much shallower than the anticipated repository depth, and because control and monitoring of boreholes in the Columbia Plateau region have been good, it is anticipated that the avoidance of existing holes will be a relatively simple task.

Abandoned water wells appear to be the only major concern with respect to undetected boreholes. The problem will have to be studied when a candidate site is selected. However these boreholes are generally far shallower than the anticipated depth of the repository. The mere presence of a borehole is not a significant safety hazard though. It still requires: 1) another phenomenon to breach the repository, and 2) a driving force such as an artesian head or pumping activity to move water through the repository and up the borehole to the surface. New holes associated with resource exploration are not included in this undetected borehole category.

Basaltic Ring Structures

Basaltic ring structures are circular geomorphological anomalies that have been located on the Columbia Plateau. The best examples are found in a $60 \mathrm{~km}^{2}$ 


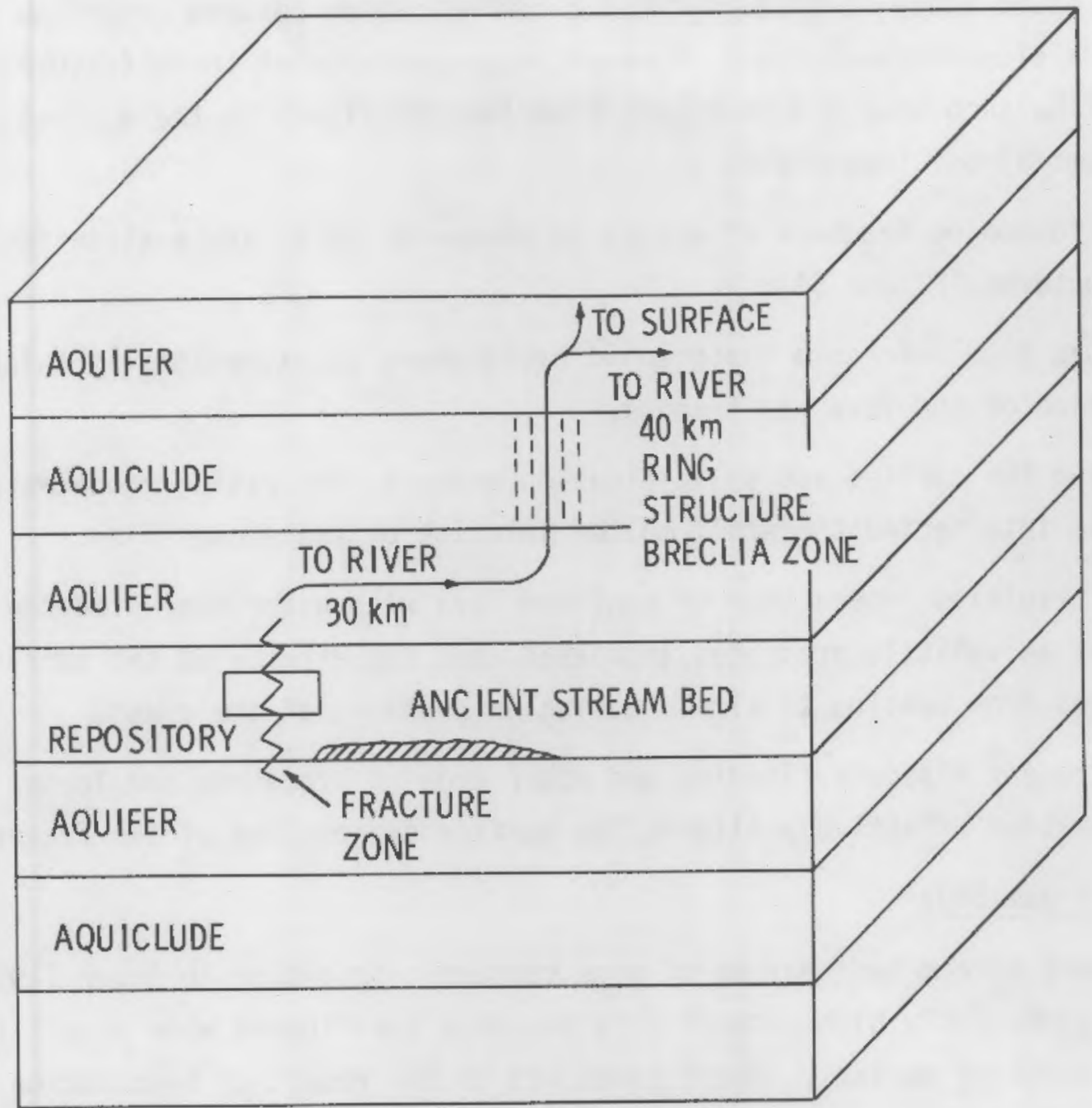

FIGURE 53. Potential Consequences Associated with Undetected Features

area within the channeled scablands around Odessa. The features are relatively smal1, 50 to $500 \mathrm{~m}$ across. Exposures are restricted largely to the scabland coulees and immediate environs where they have been exhumed from beneath widespread loess deposits (Hodges 1978).

The suggestion has been made that ring structures are restricted to a single basalt flow, in this case the Roza member of the Yakima Basalt sequence. In the Odessa area, the Roza is approximately 70-100 m thick, about twice its usual thickness elsewhere, so that a pre-Roza topographic basin is implied. Such features might be hypothesized for other flows if a specific set of conditions were met at the time of, and subsequent to, flow emplacement. Such 
features could imply vertical hydraulic communication between interflow zones bounding a single basalt flow. However, superposition of these features from flow to flow such that a direct path from the repository to the surface could exist seems almost impossible.

The following sequence of events is presented as an explanation for the ring structures (Figure 54):

- A Roza flow overran a topographic basin where an exceptionally thick section of the lava was trapped.

- During the cooling and solidification process, the rising groundwater table intersected the still molten interior of the ponded flow.

- The resulting interaction of confined lava with water disrupted the crust as volatile pressures increased, and the effects at the surface ranged from venting to simple doming or cracking of the crust.

- Subsequent Missoula flooding and other erosion processes and loess deposition effectively altered the surface expressions of the features.

Remnant Stream Beds

Remnant stream beds may be of some concern. According to Brown (1978), zones of anomalously high permeability may have been formed when basalt flows overrode existing streams. These zones may be the result of brecciation at the base of the flow or of the basalt covering porous sands and gravels in the stream bed.

These features would tend to follow the ancient drainage patterns and would tend to be relatively narrow (Figure 55). According to Brown (1978) there are exámples of linear or meandering zones of successful water wells. However, wells drilled a few hundred feet off the flank of the zone produce very little water production. The explanation is that the width of the successful well zone correlates with the width of an ancient stream bed, and that the linear or meandering sequence of wells are following the ancient stream course.

The implications of these zones are: 1) the volume of water available to these wells should be limited since recharge to such a feature would probably 

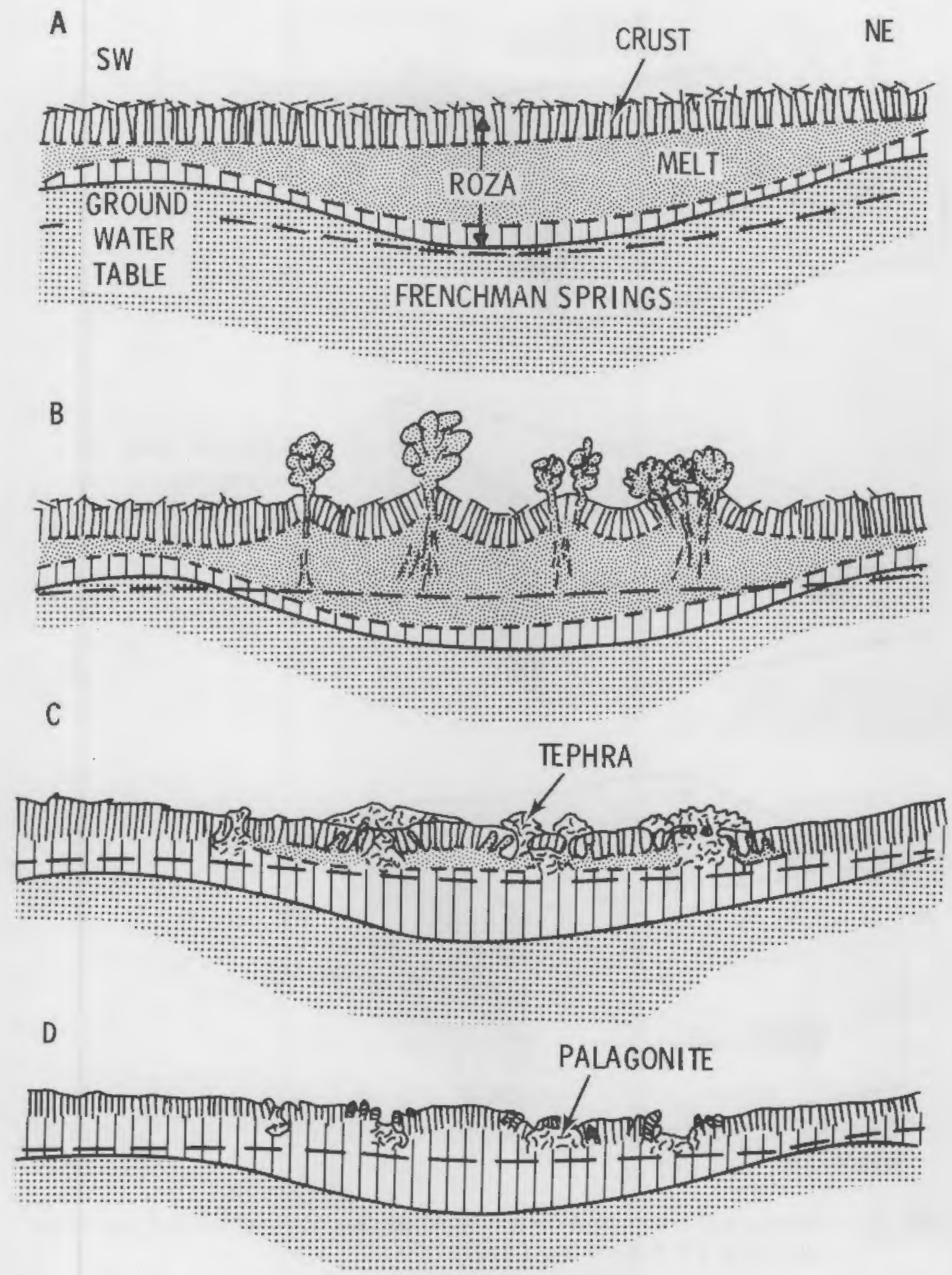

FIGURE 54. Sequence of Events Postulated to Explain the Basaltic Ring Structures. (A) Roza Flow Ponded over a Topographic Low. (B) Intersection of Rising Groundwater Table with Molten Interior of Basalt Flow. (C) Subsidence of the Crust, with Intrusion of Lava into Fractures. (D) Present Landscape After Erosion. (Hodges 1978) 


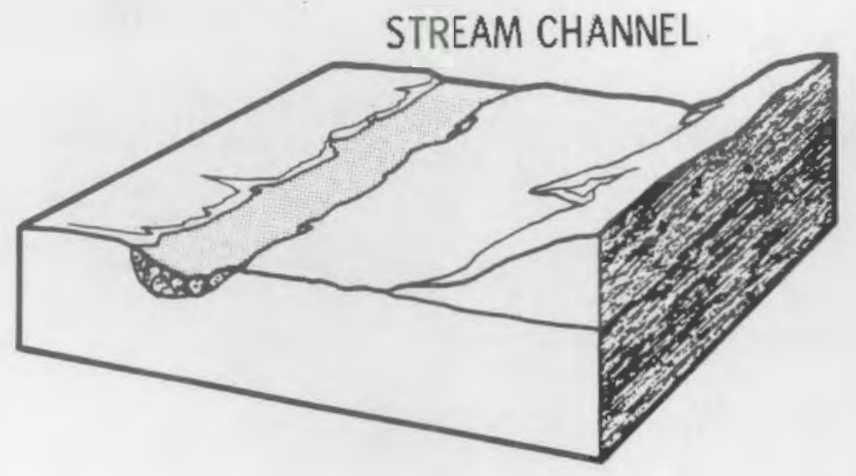

ADVANC ING

BASALT FLOW

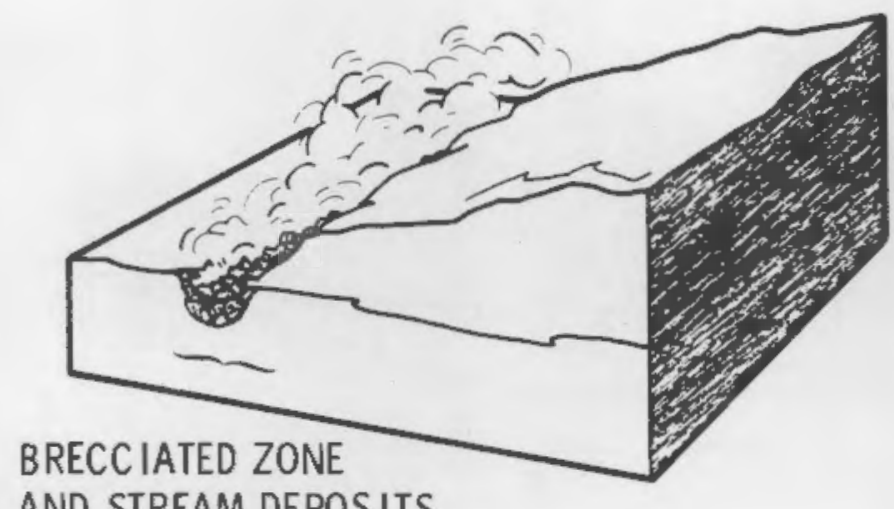

BRECCIATION AT BASE OF

BASALT FLOW AND

COVERING OF CHANNEL

DEPOSITS

AND STREAM DEPOSITS

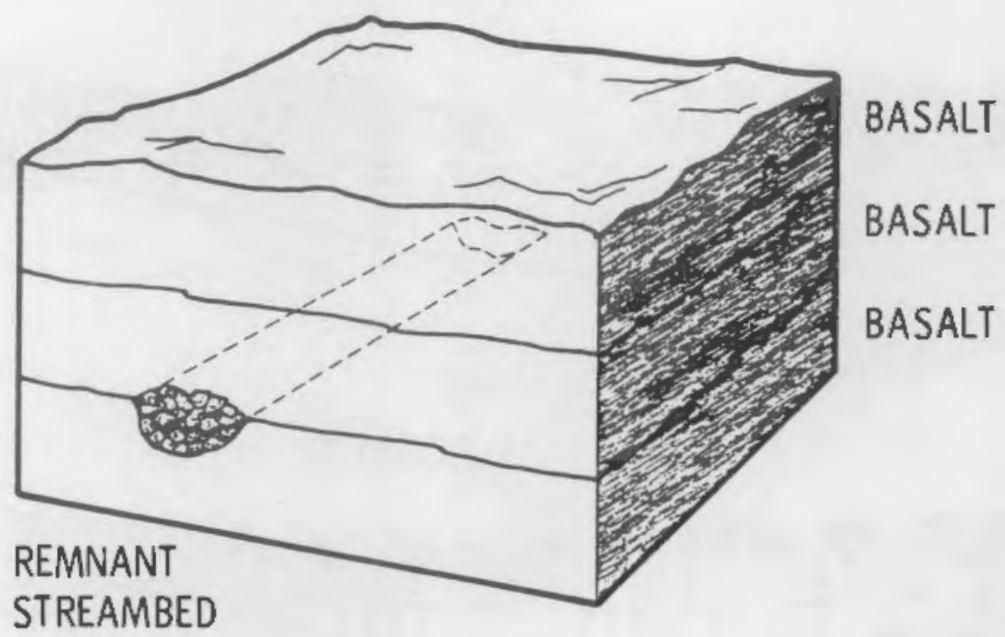

FIGURE 55. Remnant Stream Beds a) Pre-Flow Conditions b) During Flow Advance c) Post-Flow Conditions 
be slight, 2) these zones may be potential migration pathways, and 3) given the narrow dimension, they may be difficult to locate during the exploratory phase of the project. The zones, however, tend to be of limited extent or discontinuous in nature.

Lava Tubes

Lava tubes are cavernous features which in some cases can extend significant distances. It is speculated that they are formed by trapped fluids existing with a cooling magma body. To date, no lava tubes have been confirmed to exist within the Columbia Plateau.

Summary

Undetected features include features such as boreholes, ring structures, breccia pipes, remnant stream beds, folds, and faults. The potential consequences of such features include: 1) a short circuit path between confined aquifer systems and thereby a possible change of transport pathlengths and hydraulic conditions, and 2) sources of significant quantities of ground water. Figure 56 presents the logic flow for this submodel. Table 32 presents the data requirements and availability. 


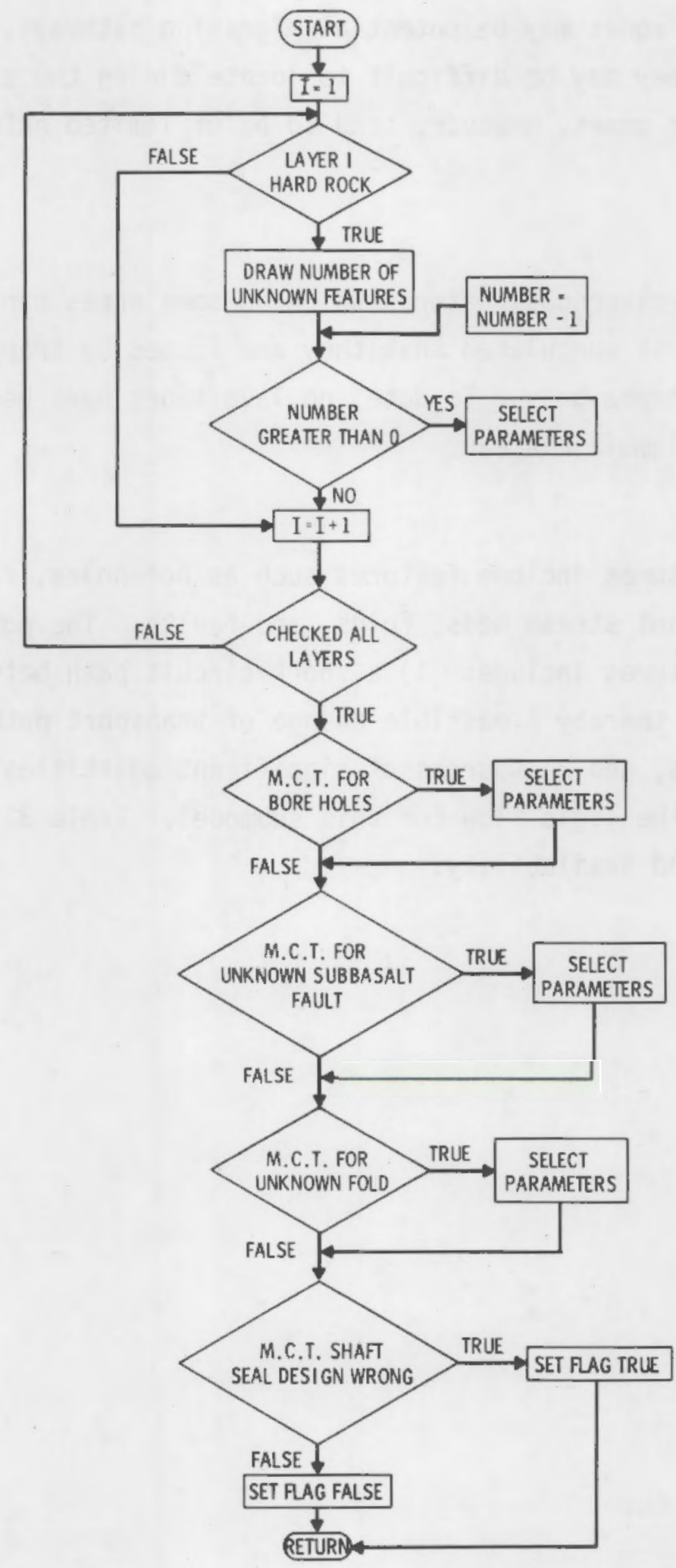

FIGURE 56. Logic Flow for Undetected Features 


\section{TABLE 32. Undetected Feature Submodel Data ${ }^{(a)}$}

SUBJECT

ILLUSTRATIVE

COMMENTS

GRAPHICAL REPRESENTATION OR DATA

\begin{tabular}{|c|c|c|}
\hline $\begin{array}{l}\text { VERTICAL TRANSMISSIVITY } \\
\text { DENSITY FUNCTION }\end{array}$ & $\ln _{0.0001}$ & $\begin{array}{l}\text { DIFFERENT 'HUMPS' MAY REPRE- } \\
\text { SENT DIFFERENT FEATURES (EX. } \\
\text { RING STRUCTURE) }\end{array}$ \\
\hline $\begin{array}{l}\text { DENSITY FUNCTION FOR DIRECTION } \\
\text { IN CLOCKWISE DEGREES FROM } \\
\text { MAIN GROUNDWATER FLOW }\end{array}$ & DEGRES & UNIFORM DISTRIBUTION \\
\hline $\begin{array}{l}\text { DENSITY FUNCTION FOR } \\
\text { DISTANCE TO UNKNOWN FEATURE }\end{array}$ & 0.01 & \\
\hline $\begin{array}{l}\text { DENSITY FUNCTION FOR DEPTH } \\
\text { OF BORE HOLE }\end{array}$ & PERMEABUITY & \\
\hline $\begin{array}{l}\text { DENSITY FUNCTION FOR VERTICAL } \\
\text { TRANSMISSIVITY OF A LOST } \\
\text { BORE HOLE }\end{array}$ & IreASSMISSIVIITY & \\
\hline $\begin{array}{l}\text { CHANCE FOR AN UNKNOWN } \\
\text { BORE HOLE }\end{array}$ & & \\
\hline $\begin{array}{l}\text { CHANCE FOR AN UNDETECTED } \\
\text { SUB-BASALT FAULT }\end{array}$ & & \\
\hline $\begin{array}{l}\text { CHANCE FOR UNDETECTED } \\
\text { FOLD }\end{array}$ & & \\
\hline $\begin{array}{l}\text { CHANCE FOR A FOLD, IF FOUND } \\
\text { BEING A MONOCLINE }\end{array}$ & & \\
\hline $\begin{array}{l}\text { MAXIMUM DISTANCE TO AXIS IF } \\
\text { EAST-WEST FOLD OR FAULT }\end{array}$ & & \\
\hline $\begin{array}{l}\text { CHANCE FOR DESIGN ERROR } \\
\text { IN SHIFT SEAL }\end{array}$ & & \\
\hline $\begin{array}{l}\text { AVERAGE NUMBER OF UNDETECTED } \\
\text { FEATURES (MAX OF 5) }\end{array}$ & & FOR POISSON DISTRIBUTION \\
\hline
\end{tabular}

(a) Data is under development and is not available at this time. 
TABLE 32. (contd)

\begin{tabular}{|c|c|c|}
\hline $\begin{array}{l}\text { REQUIRED } \\
\text { INPUT }\end{array}$ & $\begin{array}{l}\text { AVAILABLE } \\
\text { DATA }\end{array}$ & COMMENTS \\
\hline $\begin{array}{l}\text { TRANSPORT } \\
\text { DISTANCES FOR } \\
\text { LAHARS }\end{array}$ & $\begin{array}{l}\text { BASALTIC } 6.0 \mathrm{~km} \\
\text { ANDESITIC } 30.0 \mathrm{~km} \\
\text { SILICIC } 40.0 \mathrm{~km}\end{array}$ & \\
\hline $\begin{array}{l}\text { TRANSPORT } \\
\text { DISTANCE FOR } \\
\text { PYROCLASTIC FLOW }\end{array}$ & $\begin{array}{l}\text { BASALTIC } 20.0 \mathrm{~km} \\
\text { ANDESITIC } 30.0 \mathrm{~km} \\
\text { SILICIC } 50.0 \mathrm{~km}\end{array}$ & \\
\hline $\begin{array}{l}\text { TRANSPORT DISTANCE } \\
\text { FOR AIR FALL }\end{array}$ & $\begin{array}{l}\text { BASALTIC REGIONAL } \\
\text { ANDESITIC REGIONAL } \\
\text { SILICIC GLOBAL }\end{array}$ & \\
\hline $\begin{array}{l}\text { PROBABILITY OF THE } \\
\text { SITE BEING DIRECTLY } \\
\text { INTERSECTED }\end{array}$ & $\begin{array}{l}\text { INSUFFICIENT DATA ON GENERAL } \\
\text { MAGMATIC PROBABILITY AND TYPE. } \\
\text { GIVEN THIS, A GEOMETRICAL } \\
\text { CALCULATION CAN YIELD THE } \\
\text { INTERSECTION PROBABILITY }\end{array}$ & \\
\hline $\begin{array}{l}\text { AMOUNT OF WASTE } \\
\text { TRANSPORTED BY LAVA }\end{array}$ & $\begin{array}{l}\text { INTERSECTION - TOTAL INVENTORY } \\
\text { NO INTERSECTION - NONE }\end{array}$ & $\begin{array}{l}\text { BASED ON: 1) PROBABILITY } \\
\text { OF ACTIVITY WITHIN } 50 \mathrm{~km} \\
\text { 2) TYPE OF ACTIVITY, 3) } \\
\text { DISRUPTION HEI GHT, WIDTH } \\
\text { AND DEPTH, AND 4) THE } \\
\text { SIZE OF THE REPOSITORY }\end{array}$ \\
\hline $\begin{array}{l}\text { AMOUNT OF WASTE } \\
\text { TRANSPORTED IN A } \\
\text { HYDROTHERMAL SYSTEM }\end{array}$ & INSUFFICIENT DATA & \\
\hline $\begin{array}{l}\text { EFFECT ON SURFACE } \\
\text { DRAINAGE AND EROSION }\end{array}$ & INSUFFICIENT DATA & $\begin{array}{l}\text { PRIMARILY DUE TO LAVA } \\
\text { BLOCKING RIVER ROUTES } \\
\text { AND ASH FALL ELIMINATING } \\
\text { VEGETATION }\end{array}$ \\
\hline $\begin{array}{l}\text { EFFECT ON AQUIFER } \\
\text { RECHARGE AND FLOW }\end{array}$ & INSUFFICIENT DATA & $\begin{array}{l}\text { THIS SHOULD BE CONSIDERED } \\
\text { SINCE THE DEEP AQUIFER } \\
\text { RECHARGE AREAS MAY IN } \\
\text { SOME CASES BE NEAR TO } \\
\text { THE CASCADE VOLCANIC ZONE }\end{array}$ \\
\hline $\begin{array}{l}\text { LITHOSTATIC STRESS } \\
\text { FACTOR }\end{array}$ & $\begin{array}{l}0,22 \text { BARS } m^{-1} \text { OF LAVA } \\
\text { THICKNESS }\end{array}$ & \\
\hline
\end{tabular}




\section{REPORT SUMMARY}

The following topics are briefly summarized in this section: 1) interface between Release Scenario Analysis and Release Consequence Analys is Tasks, 2) site specific nature of the methodology, 3) the example submodels developed for the Columbia Plateau region, 4) incorporation of results from near-field studies, 5) interface between the Release Scenario and specific site managers, 6) and the flexibility of the tool and the requirements for interactive computer graphics.

\section{Interface Between Release Scenario and Release Consequence Studies}

The repository simulation model is applicable only to a release scenario analysis. Release consequence analys is requires tools such as numerical groundwater and nuclide transport codes. The interface between these two tasks is very critical.

If operated purely in the interactive mode, a case history (scenario) can be established and simulated. If no breach is detected, then the operator can change the data distributions or select a new scenario. If a breach is detected, then the operator can record the time of the breach to specify the nuclide inventory and he can initialize the geohydrological system upon which to run the transport codes. The most important variables are pathlengths, hydraulic conductivities, fluid potentials, and lithologies along the path.

If the Monte Carlo mode is selected, thousands of case histories (scenarios) can be generated, some of which may differ only by the magnitude or rate of a single phenomenon. When the variance in the output falls within a specified interval, then the program is automatically terminated. At this point, the consequence analyst can specify any desired time, e.g., $10^{3}$, $10^{4}, 10^{5}, 10^{6} \mathrm{yr}$, and receive a breach status report. If any breaches were detected in any of the simulations at the end of the selected time period, then the operator can access information concerning the range of conductivities, fluid potentials, pathlengths, etc. Alternatively, he can retrieve individual case histories with detailed descriptions and associated probability data. It is important to remember that each time a selection is made from a data density. 
curve, a probability number is associated with it. Therefore, a cumulative probability is associated with any given breach identified within the set of simulations.

Site Specific Nature of the Problem

A Repository Simulation mode1 must be developed for each site and carefully tailored to the governing rules and data distributions associated with that site. Site specific assessments are mandatory and simulation modeling can only be as good as the understanding and quantifying of the physical and chemical system. The methodology is transferable from site to site, but the specific codes are not. Modularizing models may expedite the transfer from one site to another.

Columbia Plateau Submodels

Eleven submodels have been developed for the Columbia Plateau region of Eastern Washington. These submodels include:

- Climate

- Continental glaciation

- Alpine glaciation

- Sea level fluctuations

- Geomorphic events

- Deformation

- Sub-basalt basement faulting

- Shaft seal failure

- Undetected features

- Magmatic activity

- Meteorites.

It is anticipated that the preliminary submodels will generate future discussion. Such models will evolve and improve with time, and these twelve versions are designed as preliminary examples. It is anticipated that as specific site managers, e.g., Rockwell Basalt Waste Isolat ion Program, extend the available data base and our knowledge of the geology, geophysics, and hydrology of the Columbia Plateau, that the Release Scenario Analysis Submodels will be altered accordingly. 
Incorporation of Near Field Results

By direction, the methodology described here does not explicitly include such near-field topics as mining induced stresses, thermal loading, and/or geochemical alterations produced by the repository and contents. Such phenomena tend to dominate the picture in the first hundred years or so. It is anticipated that the results of these near-field studies will be considered in initializing the Layered Earth Model. For example, if differential thermal expansion and/or contraction has a certain probability of increasing the bulk conductivity of a host rock, then the initial permeability of the host rock in the Repository Simulation model will reflect this change. Thus the initial LEM characteristics may be representative of the possible state of the system at the end of 100 years.

\section{Interfacing With Specific Site Managers}

The Columbia Plateau has been selected as an illustrative case only. In no way should this report be considered as a preliminary safety study for the area. Significant cooperation and interaction between the modeling group and the Site Contractor are necessary. As the understanding of a specific site improves, so must the Release Scenario and Release Consequence models. In addition, it is important to note that these models will both emphasize the strengths of a potential site as well as highlight any identifiable weaknesses. Parametric analyses may facilitate this effort. In other words, the primary mission of the Release Scenario task is to anticipate all of the questions that may arise in future formal proceedings. Only in this manner can defensible and logical answers be available for discussion. It is anticipated that a properly chosen site may be perturbed by disruptive phenomena discussed in this report, but should not be breached or failed with an "unacceptable" occurrence probability. The Release Scenario model may assist in demonstrating this fact or alternatively assist in disqualifying a site from further consideration. Interactive Utilization of the Tool

The black-box syndrome represents one potential weakness of the proposed methodology. To combat this problem, emphas is is being placed on interactive computer graphics with a light-pen sensitive scope. Block diagrams similar to 
that in Figure 7 can be scanned by a small group of users. If more analys is of the Glaciation submodel is desired, for example, a mere touch of the lightpen to that specific block on the screen will result in the projection of the logic flow diagrams for that submodel. Another touch of the pen to a specific component of the submodel will result in projection of the data associated with that component. In this manner, the user can interrogate the complete logic chain and change any input data distribution desired. The operator can specify the scenario components, their order, timing, magnitudes, rates and lag times. Once the operator is satisfied with his understanding of how the system works and the sensitivity of the output to perturbutions of the input, he can select the Monte Carlo mode and generate multiple scenario and output distributions. 


\section{REFERENCES}

Authur D. Little, Inc. 1978. Technical Report for Radiation Standards for High-Level Radioactive Waste Management. Subtask D Report, "Assessment of Accidental Pathways." EPA Contract No. 68-01-4470. Office of Radiation Programs, Environmental Protection Agency. Washington, DC.

Baker, V. R. 1973. "Paleohydrology and Sedimentology of Lake Missoula Flooding in Eastern Washington." Geol. Soc. Amer. Spec. Paper 144.

Basalt Waste Isolation Program Monthly Report. RH0-BWI-78-100. Rockwell Hanford Operations, Richland, Washington.

Biot, M. A. 1965. Mechanics of Incremental Deformation. John Wiley and Sons, Inc., New York.

Bishop, T. N. and H. P. Foote. 1978. A Seismic Data Base and Associated Graphical Capabilities. PNL-2893, Pacific Northwest Laboratory, Richland, Washington.

Bond, F. W. 1978. Basalt Waste Isolation Report RH0-8WI-78-100. Rockwel1 Hanford, Richland, Washington.

Brace, W. F. 1978. Fluid Permeability in Rock-Theory and Observation. In Symposium on Current Developments in Rock Engineering. Massachusetts Institute of Technology, Cambridge, Massachusetts.

Bredehoeft, J. D., A. W. England, D. B. Stewart, N. J. Trask, and I. J. Winogard. 1978. "Geologic Disposal of High Level Radioactive Wastes-Earth Science Perspectives." U.S. Geological Survey Circular. $799: 15$.

Bretz, K. J. 1969. "Lake Missoula Floods and the Channeled Seablend. J. Geol. 77:505.

Brotchie, J. F. and R. Silvester. 1969. "On Crustal Flexure." Journal of Geophysical Research. 74:5240-5252.

Brown, R. E. 1968. A Study of Reported Faulting in the Pasco Basin. BNWL-662, Pacif ic Northwest Laboratory, Richland, Washington.

Budyko, M. I. 1968. "On the Causes of Climate Variations." Sveriges Met. Hydrog. Inst. Medd. 28(B):6-13.

Bul1, C. 1979. "Glaciological Parameters of Disruptive Event Analysis." In A Summary of FY-1978 Consultant Input for Scenario Methodology Development, ed. B. L. Scott. PNL-2851, Pacific Northwest Laboratory, Richland, Washington. 
Bullard, F. M. 1976. Volcanoes of the Earth. University of Texas Press, Austin, Texas.

Carson, M. A. and M. J. Kirkby. 1972. Hills lope Form and Process. Cambridge University Press, Cambridge, Massachusetts.

Coombs, H. A. 1979. "Structural Geology of the Columbia Plateau and Environs as Related to the Waste Isolation Safety Assessment Program." In A Summary of FY-1978 Consultant Input for Scenario Methodology Deve lopment, ed. B. L. Scott. PNL-2851, Pacific Northwest Laboratory, Richland, Washington.

Crandall, D. R. and D. R. Mullineaux. 1975. "Technique and Rationale of Volcanic Hazards Appraisals in the Cascade Range, Northwestern U.S." Environmental Geology. 1(1):23-32.

Crowe, B. M. 1979. "Disruptive Event Analysis-Volcanism and Igneous Intrusion. In A Summary of FY-1978 Consultant Input for Scenario Methodology Development, ed. B. L. Scott. PNL-2851, Pacific Northwest Laboratory, Richland, Washington.

Davis, S. N. 1979. "Hydrogeologic Effects of Natural Disruptive Events on Nuclear Repositories." In A Summary of FY-1978 Consultant Input for Scenar io Methodology Development, ed. B. L. Scott. PNL-2851, Pacific Northwest Laboratory, Richland, Washington.

Fournier, F. 1960. Climat et Erosion. Presses Universitaires de France. Paris.

Gera, F. and D. G. Jacobs. 1972. Considerations in the Long-Term Management of High-Level Radioactive Wastes. ORNL-4762, Oak Ridge National Laboratory, Oak Ridge, Tennessee.

Goldthwait, R. P. et al. 1965. "Pleistocene Deposits of the Erie Lobe." Quarternary History of the United States, ed. H. E. Wright and D. G. Frey, pp. 63-97. Princeton University Press, Princeton, New Jersey.

Gretener, P. E. 1967. "Significance of the Rare Event in Geology." American Association of Petroleum Geologists Bulletin. 51(11):2197-2206.

Hartman, W. K. 1979. "Long Term Meteorite Hazards to Buried Nuclear Waste." In A Summary of FY-1978 Consultant Input for Scenario Methodology Development, ed. B. L. Scott. PNL-2851, Pacific Northwest Laboratory, Richland, Washington.

Hodges, C. A. 1978. "Basaltic Ring Structures of the Columbia Plateau." Geological Society of America Bulletin. 89:1281-1289.

Holeman, J. N. 1968. "The Sediment Yield of Major Rivers of the World." Water Resources Res. 4(4):737-747. 
Holling, J. T. 1977. "Thames Interglacial Sites, Ipswichian Sea Levels and Antarctic Ice Surges." Boreas. 6:32-52.

Holmes, A. 1960. "A Revised Geological Time-Scale." Edinburgh Geol. Soc. Trans. 17(13): 183-215.

Humphreys, W. J. 1942. Way of the Weather, a Cultural Survey of Meteorology. The Ronald Press Company, New York.

Jamison, D. B. and G. W. Cook. 1978. An Analys is of the Measured Values for the State of Stress in the Earth's Crust. Technical Progress Report, LBL 7071, Lawrence Berkeley Laboratory, Berkeley, California.

Judson, S. 1968. "Erosion Rates Near Rome, Italy." Science. 160:1444-1446.

Judson, S., and D. F. Ritter. 1964. "Rates of Regional Denudation in the United States." J. Geophys. Res. 69:3395-3401.

Kukla, G. K. 1979. "Probability of Expected Climate Stresses in North America in the Next One Million Years." In A Summary of FY-1978 Consultant Input for Scenario Methodology Development, ed. B. L. Scott. PNL-2851, Pacific Northwest Laboratory, Richland, Washington.

Lamb, H. H. 1970. "Volcanic Dust in the Atmosphere, with a Chresology and Assessment of its Meteorological Significance." Roy. Soc. London Phil. Trans. A266:425-533.

Leopold, L. B. et al. 1964. Fluvial Processes in Geomorphology. W. H. Freeman, San Francisco, California.

Lindren, E. N. and J. A. Halpern. 1977. "In-Situ Stress Analysis." Presented at the 18th U.S. Symposium on Rock Mechanics.

Logan, S. E. and M. C. Berbano. 1977. "Geologic Modeling in Risk Assessment Methodology for Radioactive Waste Management." In Proceedings of Workshop Organized Jointed by the OECD Nuclear Energy Agency and the Commission of European Communities, pp. 77-115. May 23-27.

Malone, S. D., G. H. Roth, and S. W. Smith. 1975. "Details of Microearthquake Swarms in the Columbia Basin." Washington Bull. Seism. Soc. Am. $65: 855-864$.

Mathews, W. H. 1975. "Cenozoic Erosion and Erosion Surfaces of Eastern North America." American Journal of Science. 275:818-824.

McGinnis, L. D. 1968. "Glaciation as a Possible Cause of Mineral Deposition." Economic Geology. 63:390-400.

McKee, B. 1972. Cascadiae. McGraw Hill, New York. 
0'Keefe, J. D. and T. J. Ohrens. 1977. "Impact-Induced Energy Partitioning, Melting, and Vaporization on Terrestrial Planets." In Proceedings of the Lunar Science Conf. 8:33-57.

Peltier, W. R. and J. T. Andrews. 1976. "Glacial-Isostatic Adjustment-I The Forward Problem." Geophysical Journal of Royal Astronomical Society. 46:605-646.

Pratt, H. R., W. A. Hustrulid, and D. C. Stephenson. 1978. Earthquake Damage to Underground Facilities. Topical Report, DP-1513. Savannah River Laboratory, Aiken, South Carolina.

Rothe, G. H. 1978. "Earthquake Swarms in the Columbia River Basalts." Ph.D. Thesis. University of Washington, Seattle, Washington.

Ruddiman, W. F. 1977. "Late Quarternary Deposition of Ice-Rafted Sand in the Subpolar North Atlantic (1at. 40 to $65 \mathrm{~N}$ )." Bulletin of the Geological Society of America. 88:1813-1827.

Schumm, S. A. 1963. "The Disparity Between Present Rates of Denudation and Orogeny." U.S. Geological Survey Professional Paper 454-H. pp. H1-H13.

Schwartz, M. L. 1978. "Sea Level Characteristics for the Next One Million Years." In A Summary of FY-1978 Consultant Input for Scenario Methodology Development, ed. B. L. Scott. PNL-2851, Pacific Northwest Laboratory, Richland, Washington.

Shackleton, N. J. and Opdyke, N. D. 1973. "Oxygen Isotope and Poleomagnetic Stratigraphy of Equational Pacific Core V28-238: 0xygen Isotope Temperatures and Ice Volumes on a $10^{5}$ and $10^{5}$ Year Scale." Quarternary Research. 3:39-55.

Sugden, D. E. 1976. "A Case Against Deep Erosion of Shields by Ice Sheets." Geology. 4:580-582.

Swanson, D. A., T. L. Wright, and R. T. Helz. 1975. "Linear Vent Systems and Estimated Rates of Magmo Production and Eruption for the Yakima Basalt on the Columbia Plateau." Amer. J. Sci. 275:877-905.

Tauberneck, W. H. 1970. "Dikes of the Columbia River Basalt in Northeastern Oregon, Western Idaho, and Southeastern Washington." In Proceedings 2nd Columbia River Basalt Symposium, E. H. Gilmour and D. Steadling, eds. Eastern Washington State College, Cheney, Washington. pp. 73-96.

Tubbs, D. W. 1979. "Pacific Northwest Geomorphology and Hydrology-Rates and Probabilities of Selected Processes and Events." In A Summary of FY-1978 Consultant Input for Scenario Methodology Development, ed. B. L. Scott. PNL-2851, Pacific Northwest Laboratory, Richland, Washington. 
U.S. Army Corps of Engineers. 1950. "Columbia River and Tributaries." House Document 531, Appendix F.

Walcott, R. I. 1972. "Post Sea Levels, Eustacy, and Deformation of the Earth." Quarternary Research. 2:1-14.

Waters, A. C. 1955. Geomorphology of South-Central Washington, I1lustrated by the Yakima Quadrangle. Geol. Soc. Amer. Bull. 66:663-684.

Weertman, J. H. 1964. "Rate of Growth or Shrinkage of Non-Equilibrium Ice Sheets." Journal of Glaciology. 5:145-158.

Weertman, J. H. 1976. "On Milankovitch Solar Radiation and Variations in Ice Sheet Sizes." Nature. 261:17-20.

White, W. A. 1972. "Deep Erosion by Continental Ice Sheets." Bulletin of the Geological Society of America. 83:1037-1056.

Wight, L. H. 1979. "Analys is of the Seismic Hazard to an Underground Waste Repository." In A Summary of FY-1978 Consultant Input for Scenario

Methodology Development, ed. B. L. Scott. PNL-2851, Pacific Northwest Laboratory, Richland, Washington.

Zoback, D. A. and T. L. Thompson. 1977. Amendment 23 PSAR 2RC. Washington Public Power Supply System, Richland, Washington. 

APPENDIX 
APPENDIX

\section{GLOSSARY OF TERMS}

alluvial fan: A fan-shaped deposit formed by a stream either where it issues from a narrow mountain valley onto a plain or broad valley, or where a tributary stream joins a main stream.

alluvium: The detrital materials eroded, transported, and deposited by streams; an important constituent of shelf deposits. Also known as alluvial deposit; alluvion.

anticline: A fold in which layered strata are inclined down and away from the axes.

*aquiclude: A body of saturated but relatively impermeable material that does not yield appreciable amounts of water to wells. Characterized by very low "leakance" (the ratio of vertical hydraulic conductivity to thickness) and very low rates of yield from compressible storage.

aquifer: A formation, group of formations, or part of a formation that contains sufficient saturated permeable material to yield significant quantities of water to wells and springs.

aquitard: A confining bed that retards but does not prevent the flow of water to or from an adjacent aquifer; a leaky confining bed.

artesian aquifer: An aquifer that is bounded above and below by confining beds. Also known as confined aquifer.

basement: A complex, usually of igneous and metamorphic rocks, that is overlain unconformally by sedimentary strata.

basin: 1. A low-lying area, wholly or largely surrounded by higher land, that varies from a small, nearly enclosed valley to an extensive, mountain-rimmed depression. 2. An entire area drained by a given stream and its tributaries. 3. An area in which the rock strata are inclined downward from all sides toward the center. 4. An area in which sediments accumulate. 
batholith: A body of igneous rock, 40 square miles or more in area, emplaced at great or intermediate depth in the earth's crust.

block faulting: A type of normal faulting in which the crust is divided into structural or fault blocks of different elevations and orientations. It is the process by which block mountains are formed.

breccia: 1. Fragmental rock whose components are angular and therefore, as distinguished from conglomerates, are not waterworn. There are friction or fault breccias, talus breccias, and eruptive breccias. 2. A rock made up of highly angular coarse fragments. May be sedimentary or formed by crushing or grinding along faults.

cap rock: 1. A disk-like plate over all or part of the top of most salt domes in the Gulf Coast states composed of anhydrite, gypsum, 1 imestone, and occasionally sulfur. 2. A comparatively impervious stratum immediately overlying an oil-or gas-bearing rock.

chimneying: The process of progressive collapse of rock overlying an explosion-produced cavity resulting in a tall under ground cylinder (chimney). clastic: Rock or sediment composed of fragments that have been transported from their place of origin, as sandstone and shale.

cleavage: Splitting, or the tendency to split, along parallel, closely positioned planes in rock.

columnar jointing: Cracks that break rocks into polygonal columns, usually forms in volcanic rocks because of cooling and shrinking.

conglomerate: Cemented, rounded fragments of water-worn rock or pebbles, bound by a siliceous or argillaceous substance.

consolidated (material): In geology, natural materials that have been made firm, cohesive, and hard.

crust: Outer layer of the earth above the mantle. crystalline rock: An inexact general term for igneous and metamorphic rocks as opposed to sedimentary rock. 
curie: A unit of radioactivity, defined as that quantity of any radioactive nuclide which has $3.700 \times 10^{10}$ disintegrations per second. Abbreviated Ci.

depositional environment: A geographically restricted environment where sediment accumulates under similar physical, chemical, and biological conditions.

diagenesis: Process involving physical and chemical changes in sediment after deposition that converts it to consolidated rock; includes compaction, cementation, recrystallization, and perhaps replacement as in the development of dolomite.

diapirism: The process of piercing or rupturing of domed or uplifted overlying rocks by core material heated to the plastic state, either by tectonic stresses as in anticlinal folds, or by the effect of geostatic load in sedimentary strata as in salt domes or shale diapirs, or as in the case of igneous intrusions, forming diapiric structures such as plugs or batholiths. The concept was first applied to salt structures, which are the most common type of diapir.

differential erosion: Rapid erosion of one area of the earth's surface relative to another.

dike: A tabular body of igneous rock that cuts across adjacent rocks or cuts massive rocks.

dome: 1. A circular or elliptical, almost symmetrical upfold or anticlinal type of structural deformation. 2. A large igneous intrusion whose surface is convex upward.

ephemeral stream: A stream or reach of a stream that flows briefly only in direct response to precipitation in the immediate locality and whose channel is at all times above the water table. The term may be arbitrarily restricted to a stream that does not flow continuously during periods of as much as one month. Cf: intermittent stream. 
epoch: A division of geologic time; when capitalized it becomes a formal division of geologic time corresponding to a series of rock and a subdivision of a period.

erosion: The group of processes whereby soil or rock material is loosened or dissolved and removed from a part of the earth's surface.

fault: A fracture or fracture zone along which there has been displacement of the sides relative to one another parallel to the fracture.

fault block: A rock mass that is bounded by faults; the faults may be elevated or depressed and not necessarily the same on all sides.

fault system: Two or more fault sets that interconnect.

flood plain deposit: Sandy and clayey sediment deposited by river water spreading out over a flood plain.

foliation: A laminated structure formed by segregation of different minerals into layers that are parallel to the schistosity.

geochemistry: The study of the chemical composition of the various phases of the earth and the physical and chemical processes which have produced the observed distribution of the elements and nuclides in these phases.

geohydrology: The science dealing with underground water, of ten referred to as hydrogeo logy.

geoid: The figure of the earth considered as a sea-level surface extended continuously over the entire earth's surface.

geomorphology: The study of the origin of secondary topographic features that are carved by erosion in the primary elements and built up of the erosional debris.

geophysics: The physics of the earth and its environment, that is, earth, air, and (by extension) space.

geotherma1: Pertaining to the heat of the interior of the earth. glacial lobe: A tonguelike projection from a continental glacier's main mass. 
glacial maximum: The time or position of the greatest extent of any glaciation; most frequently applied to the greatest advance toward the equator of Pleistocene glaciation.

glaciation: Alteration of any part of the earth's surface by passage of a glacier, chiefly by glacial erosion or deposition.

graben: A block of the earth's crust, generally with a length much greater than its width, that has dropped relative to the blocks on either side. granitic: 1. Of, pertaining to, or composed of, granite or granite-like rock. 2. A term applied to coarse- and medium-grained, granular igneous rocks in which all or nearly all of the mineral constituents are anhedral (xenomorphic) and of approximately the same size.

ground water or ground-water: Subsurface water occupying a saturation zone. hydraulic conductivity: Has dimensions of length per unit time. A medium has a hydraulic conductivity of unit length per unit time if it will transmit in unit time a unit volume of groundwater at the prevailing viscosity through a cross-section of unit area, measured at right angles to the direction of flow, under a hydraulic gradient of unit change in head through unit length of flow.

hydraulic damming: Temporary ponding of water produced by a channel constriction.

hydraulic gradient: Represents the vertical change in the ground-water surface elevations per unit of horizontal.

hydrostatic pressure: 1. The pressure at a point in a fluid at rest due to the weight of the fluid above it. Also known as gravitational pressure. 2. The negative of the stress normal to a surface in a fluid.

hydrothermal: An adjective applied to heated or hot aqueous solutions, to the processes in which they are concerned, and to the rocks, ore deposits, and alteration products produced by them. Hydrothermal solutions are of diverse sources, including magmatic, meteoric, and connate waters. 
interfluve: The district between adjacent streams flowing in the same general direction.

interstice: An opening or space between one thing and another, as an opening in a rock or soil that is not occupied by solid matter. On the basis of origin, it may be classified as an original interstice or a secondary interstice; on the basis of size, as a capillary interstice, a subcapillary interstice, or a supercapillary interstice. Syn: void; pore. Adj: interstitial.

intrusion: 1. The process of emplacement of magma in pre-existing rock. Also known as injection; invasion; irruption. 2. A large-scale sedimentary injection. Also known as sedimentary intrusion. 3. Any rock mass formed by an intrusive process.

isopach: A line drawn on a map through points of equal thickness of a designated stratigraphic unit or group of stratigraphic units. Cf: isochore. Syn: isopachous line; isopachyte; thickness line; thickness contour.

joint: A fracture that traverses a rock and does not show any discernible displacement of one side of the fracture relative to the other.

laccolith: a body of igneous rock intruding into sedimentary rocks so that the overlying strata have been notably lifted by the-force of intrusion.

lava: Fluid rock such as that which issues from a volcano or a fissure in the earth's surface; also the same material solidified by cooling.

lithification: 1. Conversion of a newly deposited sediment into an indurated rock. Also known as lithifaction. 2. Compositional change of coal to bituminous shale or other rock.

1ithology: 1. The physical character of a rock, generally as determined megascopically or with the aid of a low-power magnifier. 2. The microscopic study and description of rocks. Petrography.

loess: An essentially unconsolidated, unstratified calcareous silt; commonly it is homogeneous, permeable, and buff to gray in color, and contains calcareous concretions and fossils. 
low-angle fault: A fault, the dip of which is $45^{\circ}$ or less. Cf: high-angle fault.

mafic: Refers to an igneous rock composed chiefly of one or more magnesium and iron-bearing, dark-colored minerals.

magnatism: The formation of igneous rock from magma.

mantle: The intermediate shell zone of the earth below the crust and above the core (to a depth of 3480 kilometers).

monocline: A stratigraphic unit that dips from the horizontal in one direction only; not as part of an anticline or syncline.

orogeny: The process of forming mountains. Especially the intense deformation of rocks by folding and faulting which, in many mountainous regions, has been accompanied by metamorphism, invasion of molten rock, and volcanic eruption; in modern usage, orogeny produces the internal structure of mountains, and epeirogeny produces the mountainous topography. Also known as orogenesis, tectogenesis.

outcrop: Exposed stratum or body of ore at the surface of the earth. Also known as cropout.

permeability: The capacity of a porous rock, soil, or sediment for transmitting a fluid without damage to the structure of the medium. Also known as perviousness.

plateau basalt: Those basaltic lavas that occur as vast composite accumulations of horizontal or subhorizontal flows and which, erupted in rapid succession over great areas, have at times flooded sectors of the earth's surface on a regional scale. They are generally believed to be the product of fissure eruptions.

pluton: In the strictest sense, a body of igneous rock that has formed beneath the surface of the earth by consolidation from magma. In a broader sense, it may include bodies composed of pseudoigneous rock that formed beneath the surface of the earth by the metasomatic replacement of an older rock. 
pluvial: 1. Due to the action of rain. 2. Pertaining to deposits by rainwater or ephemeral streams.

porosity: That portion of an aquifer's volume which consists of openings or pores; that is, the proportion of its volume not occupied by solid material. Porosity is an index of how much ground water can be stored in the saturated material and is usually expressed as a percentage of the bulk volume of the material.

recharge: 1. The processes involved in the replenishment of water to the zone of saturation. 2. The amount of water added or absorbed. Also known as ground-water increment; ground-water recharge; ground-water replenishment; increment; intake.

regional metamorphism: Geological metamorphism affecting an extensive area. rift: 1. narrow opening in a rock caused by cracking or splitting. 2. A high, narrow passage in a cave.

rift valley: A deep, central cleft with a mountainous floor in the crest of a midoceanic ridge. Also known as central valley; midocean rift. rift zone: A system of crustal fractures and faults.

runoff: 1. Surface streams that appear after precipitation. 2. The flow of water in a stream, usually expressed in cubic feet per second; the net effect of storms, accumulation, transpiration, meltage, seepage, evaporation, and percolation.

sedimentary basin: Geologically depressed area with thick sediments in the interior and thinner sediments at the edges.

seismicity: The phenomena of earth movements. Also known as seismic activity.

shield: A continental block of the earth's crust that has been relatively stable over a long period of time and has undergone only gentle warping in contrast to the strong folding of bordering geosyclinical belts. Mostly composed of precambrian rocks. 
sill: 1. Submarine ridge in relatively shallow water that separates a partly closed basin from another basin or from an adjacent sea. 2. A tabular igneous intrusion that is oriented parallel to the planar structure of surrounding rock.

sinkhole: A funnel-shaped depression in the land surface generally in a limestone region communicating with a subterranean passage developed by solution.

slickenside: A surface that is polished and smoothly striated and results from slippage along a fault plane.

static head: Pressure of a fluid caused by the head of fluid above some reference point.

stock: (Geol) See pipe. (Petr) A usually discordant, batholithlike body of intrusive igneous rock not exceeding 40 square miles in surface exposure and usually discordant.

strain: Change in length of an object in some direction per unit undistorted length in some direction, not necessarily the same; the nine possible strains form a second-rank tensor.

stratigraphy: A branch of geology concerned with the form, arrangement, geographic distribution, chronologic succession, classification, correlation, and mutual relationships of rock strata, especially sedimentary. Also known as stratigraphic geology.

stratum: A tabular or sheet-like mass, or a single and distinct layer, or homogeneous or gradational sedimentary material (consolidated rock or unconsolidated earth) of any thickness visually separable from other layers above and below by a discrete change in the character of the material deposited or by a sharp physical break in deposition, or by both; a sedimentary bed. The term should be restricted to sedimentary material and is generally considered to be synonymous with "bed". The term frequently used in its plural form, strata. Lamina.

strike slip: The component of the slip of a fault that is parallel to the strike of the fault. Also known as horizontal displacement; horizontal separation. 
strike-slip fault: A fault, the actual movement of which is parallel to the strike of the fault.

syncline: A fold in rocks in which the strata dip inward from both sides toward the axis. Ant: anticline.

tectonic: 0f, pertaining to, or designating the rock structure and external forms resulting from the deformation of the earth's crust. As applied to earthquakes, it is used to describe shocks not due to volcanic action or to collapse of caverns or landstides.

tectonism: 1. Crustal instability. 2. The structural behavior of an element of the earth's crust during, or between, major cycles of sedimentation.

terrace: 1. A horizontal or gently sloping embankment of earth along the contours of a slope to reduce erosion, control runoff, or conserve moisture. 2. A narrow coastal strip sloping gently toward the water. 3. A long, narrow, nearly level surface bounded by a steeper descending slope on one side and by a steeper ascending slope on the other side. 4. A benchlike structure bordering an undersea feature.

thrust fault: A low-angle (less than a $45^{\circ}$ dip) fault along which the hanging wall has moved up relative to the footwall. Also known as reverse fault; reverse slip fault; thrust slip fault.

topography: The physical features of a district or region, such as are represented on maps, taken collectively; especially, the relief and contour of the land.

transmissivity: In an aquifer, the rate at which water of the prevailing kinematic viscosity is transmitted through a unit width under a unit hydraulic gradient. Though spoken of as a property of the aquifer, it embodies also the saturated thickness and the properties of the contained liquid.

underfit stream: A stream that appears too small to have eroded the valley in which it flows. 
underthrust: A thrust fault in which the lower, active rock mass has been moved under the upper, passive rock mass.

uplift: Elevation of any extensive part of the earth's surface relative to some other parts.

upwarping: The upwards warping or uplift of a regional area of the earth's crust, usually as the result of the release of isostatic pressure, e.g., melting of an ice sheet.

water table: The planar surface between the zone of saturation and the zone of aeration. Also known as free-water elevation; free-water surface; ground-water leve1; ground-water surface; ground-water table; level of saturation; phreatic surface; plane of saturation; saturated surface; water level; waterline. 



\section{DISTRIBUTION}

No. of

Copies

OFFSITE

\section{UNITED STATES}

A. A. Churm

DOE Chicago Patent Group 9800 South Cass Avenue

Argonne, IL 60439

27 DOE Technical Information Center

2 Argonne National Laboratory Reference Library 9800 South Cass Avenue Argonne, IL 60439

20 Battelle Memorial Institute Office of Nuclear Waste Isolation

Attn: Beverly Rawles

$505 \mathrm{King}$ Avenue

Columbus, $\mathrm{OH} 43201$

Michael J. Be11, Chief

High-Level Waste Technical Development Branch

Waste Management Division

U.S. Nuclear Regulatory Commission

Washington, DC 20555

John Bird

Geology Department

Corne II University

Ithaca, NY 14853

Albin Brandstetter

Office of Nuclear Waste Isolation

505 King Avenue

Columbus, $\mathrm{OH} 43201$
No. of

Copies

2 Brookhaven National Laboratory

Reference Section

Information Division

Upton, Long Island, NY 11973

Harry C. Burkholder

Office of Nuclear Waste Isolation

Battelle Memorial Institute

505 King Avenue

Columbus, $\mathrm{OH} 43201$

Neville G. W. Cook

Dept of Materials Science and Minera 1 Engineering

Hearst Mining Building

University of California

Berkeley, CA 94720

Carl R. Cooley

DOE Office of Nuclear Waste Management

Washington, DC 20545

Mike Cullingford

Probablistic Analysis Staff

Nuclear Regulatory Commission

Mail Stop 3103

Washington, DC 20555

Stanley N. Davis, Hydrologist

The University of Arizona

College of Earth Sciences

6540 W. Box Canyon Drive

Tucson, AZ 85705

J. 0. Duguid

Battelle Memorial Institute

Office of Nuclear Waste

Isolation

505 King Avenue

Columbus, $\mathrm{OH} 43201$ 
No. of

Copies

Dan Egan

Environmental Protection Agency Office of Radiation Programs Technology Assessment Division M/S AW559

Washington, DC 20460

Larry R. Fitch

Office of Licensing

Systems Integration

Basalt Waste Isolation Project

Rockwe 11 Hanford Operations

P.0. Box 800

Richland, WA 99352

Robert M. Garre11s

Dept of Geologic Sciences

Northwestern University

Evanston, IL 60201

Mark A. Harwe 11

P.0. Box 667

Cannon Beach, OR 97110

Colin A. Heath

DOE Office of Nuclear Waste

Management

Washington, DC 20545

William M. Hewitt

Office of Nuclear Waste

Isolation

Battelle Memorial Institute

505 King Avenue

Columbus, $\mathrm{OH} 43201$

Peter L. Hofmann

Office of Nuclear Waste Isolation

Battelle Memorial Institute

505 King Avenue

Columbus, $\mathrm{OH} 43201$

Muzaffer Kehnemuyi

Office of Nuclear Waste

Isolation

Battelle Memorial Institute

505 King Avenue

Columbus, $\mathrm{OH} 43201$
No. of

Copies

John F. Kircher

Office of Nuclear Waste

Isolation

Battelle Memorial Institute

505 King Avenue

Columbus, $\mathrm{OH} 43201$

C. Kreitler

Texas Bureau of Economic Geology

University Station

P.0. Box $X$

Austin, TX 78712

Terry R. Lash

Director ofScience and Public Policy

Keystone Center

Box 38

Keystone, CO 80435

2 Lawrence Berkeley Laboratory

Reference Library

University of California

Berkeley, CA 94720

2 Lawrence Livermore Laboratory

Reference Library

P.0. Box 808

Livermore, CA 94550

2 Los Alamos Scientific Laboratory

Reference Library

P.0. Box 1663

Los Alamos, NM 87544

J. B. Martin

Asst. Director for Radioactive Waste Management Branch

NRC Division of Materials and

Fuel Cycle Facility Licensing

Washington, DC 20555

John T. McGinnis

Office of Nuclear Waste

Isolation

Battelle Memorial Institute

505 King Avenue

Columbus, $\mathrm{OH} 43201$ 
No. of

Copies

M. Merritt

WIPP

Sandia Laboratories

Albuquerque, NM 87115

2 Barry N. Naft

NUS Corporation

4 Research Place

Rockville, MD 20805

2 J. 0. Neff

Department of Energy

Columbus Program office

505 King Avenue

Columbus, $\mathrm{OH} \quad 43201$

2 Neil A. Norman

Environmental Sciences

Department

Bechtel National Inc.

P.0. Box 3965

San Francisco, CA 94105

2 Oak Ridge National Laboratory

Central Research Library

Document Reference Section

Oak Ridge, TN 37830

Frank L. Parker

Dept. of Environmental Eng.

Vanderbilt University

Nashville, TN 37235

T. H. Pigford

University of California

Berkeley, CA 94720

George F. Pinder

Dept. of Civil Engineering

Princeton University

Princeton, NJ 08540

Robert 0. Pohl

Laboratory of Atomic and

Solid State Physics

Cornell University

Ithaca, NY 14853
No. of

Copies

H. L. Ragsdale

Department of Biology

Emory University

Atlanta, GA 30322

Herbert R. Shaw

U.S. Department of the Interior

Geological Survey

Branch of Experimental Geochem. and Mineralogy

345 Middlefield Road

Menlow Park, CA 94025

D. B. Shipler

Battelle Memorial Institute

Office of Nuclear Waste Isolation

505 King Avenue

Columbus, $\mathrm{OH} 43201$

2 Savannah River Laboratory

Reference Library

Aiken, SC 29801

Arthur J. Soinski

Energy Resources Conservation and Development Commission

1111 Howe Avenue

Sacramento, CA. 95825

Howard P. Stephens

Sandia Laboratories

P.0. Box 5800

A1buquerque, NM 87115

David B. Stewart

U.S. Geological Survey

National Center 959

Reston, VA 22092

Martin s. Tierney

Environmental Assessment

Division 4514

Sandia Laboratories

Albuquerque, NM 87115

Bob E. Watt

1447 45th Street

Los Alamos, NM 87544 
No. of

Copies

R. W. Wilems

INTERA Environmental

Consultants, Inc.

11999 Katy Freeway, Suite 610

Houston, TX 77079

Robert Williams

Electric Power Research Inst. $3412^{\circ}$ Hillview Avenue

P.0. Box 10412

Palo Alto, CA 94304

Paul A. Witherspoon

Earth Sciences Division

Lawrence Berkeley Laboratory

Building 90

Berkeley, CA 94720

\section{ONSITE}

5 DOE Richland Operations Office

0. J. Elgert

R. B. Goranson

H. E. Ransom

J. J. Schreiber

F. R. Standerfer

10 Rockwe 11 Hanford Operations

R. C. Arnett

R. G. Baca

R. L. Bielefeld

0. J. Carrell
No. of

Copies

R. A. Deju

F. A. Deluca

L. R. Fitch

R. E. Gephart

L. S. Leonhart

Rockwe11 Document Control

54 Pacific Northwest Laboratory

E. M. Arnold

G. L. Genson

D. J. Bradley

T. D. Chikalla

C. R. Cole

W. J. Deutsch

F. H. Dove (20)

M. G. Foley (10)

C. T. Kincaid

M. R. Kreiter

J. W. Lindberg

R. W. Nelson

G. M. Petrie

A. M. Platt

J. V. Robinson

R. J. Serne

D. J. Silveria

J. K. Soldat

J. T. Zellmer

Technical Information Library (5)

Publishing Coordination BE (2)

Water and Land Resources Dept.

Library (10) 